Szegedi Tudományegyetem

Nyelvtudományi Doktori Iskola

Elméleti Nyelvészet Program

Szőke Bernadett

\title{
Az értelmezős szerkezetek vizsgálata \\ a magyar nyelvben
}

\author{
doktori disszertáció \\ Témavezető: Dr. Bartos Huba \\ egyetemi docens
}

Szeged

2015 


\section{KÖSZÖNETNYILVÁNÍTÁSOK}

A disszertáció elkészítése során nagyon sok támogatást kaptam mind szakmai, mind lelki téren. Mindenekelőtt szeretnék köszönetet mondani a témavezetőmnek, Bartos Hubának, aki észrevételeivel, a dolgozathoz és a cikkekhez füzött megjegyzéseivel segítette munkámat. Hálás vagyok azért is, hogy amikor úgy éreztem, holtpontra jutottam, mindig sikerült onnan kilendítenie. Köszönöm a türelmét, az évek során nyújtott bátorítást és a humorral füszerezett konzultációkat, amelyek oldották a bennem rejlő feszültséget.

Ezúton fejezem ki őszinte hálámat a disszertáció előopponenseinek, Dékány Évának és Szécsényi Krisztának, akik értékes tartalmi és formai észrevételekkel, tanácsokkal és szakirodalmi javaslattal járultak hozzá a dolgozat végső változatának elkészítéséhez.

Külön köszönet illeti Kenesei Istvánt, a szintaxis-kutatószeminárium vezetőjét és a csoport tagjait megjegyzéseikért, kérdéseikért, melyek sokat segítettek a kutatás során. Továbbá nagyon hálás vagyok azért a támogatásért, amelyet Kenesei Istvántól mint a Nyelvtudományi Doktori Iskola vezetőjétől és Németh T. Enikőtől, az Elméleti Nyelvészet Program vezetőjétől kaptam.

Szeretném kifejezni köszönetemet csoporttársamnak, Tóth Csillának, akitől nagyon sok bátorító szót kaptam az évek során.

Végül, de nem utolsósorban nagyon hálás vagyok a családomnak, legfőképpen édesanyámnak, a páromnak, valamint a barátaimnak a támogatásuk és a türelmük miatt.

Jelen kutatás elvégzését az, „Átfogó magyar nyelvtan” címü, NK 100804 azonosítószámú OTKA projekt támogatta. 


\section{Tartalom}

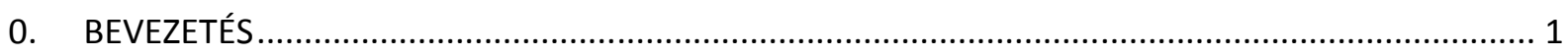

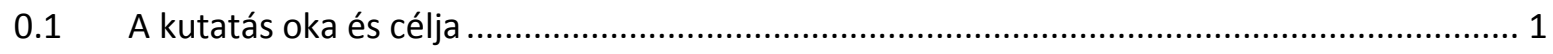

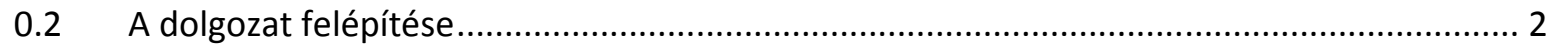

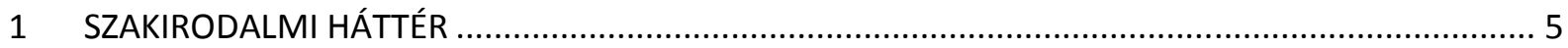

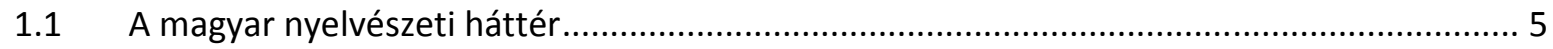

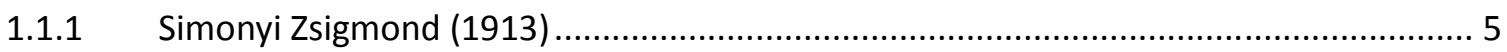

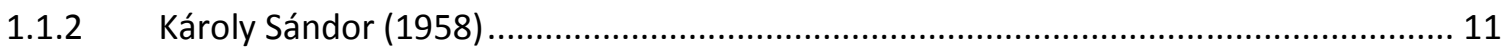

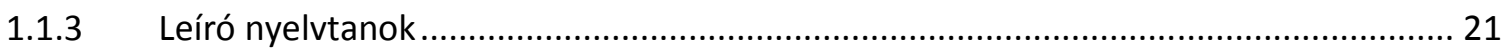

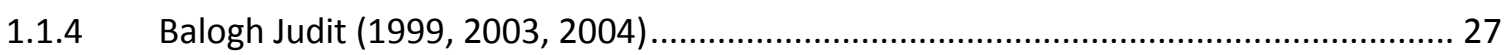

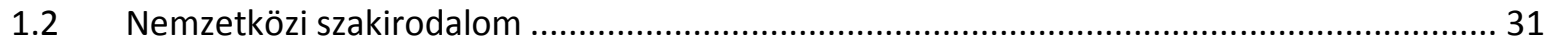

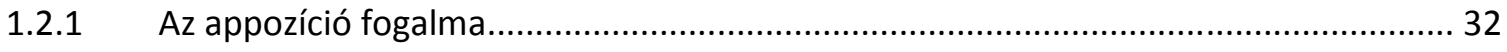

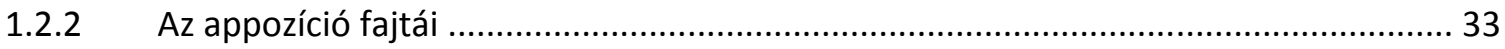

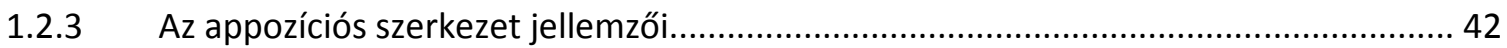

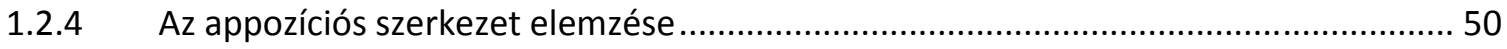

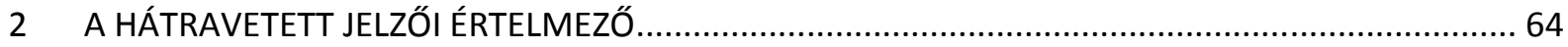

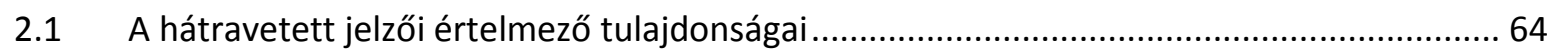

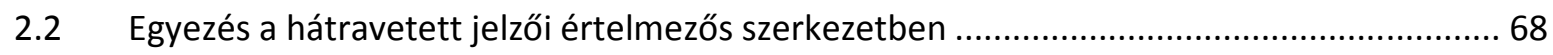

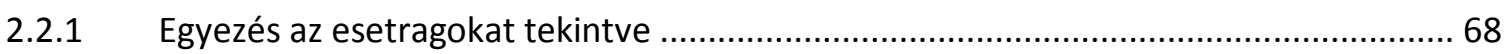

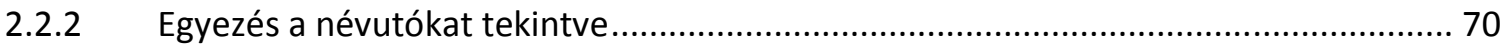

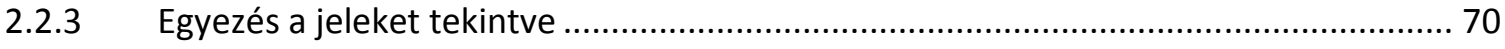

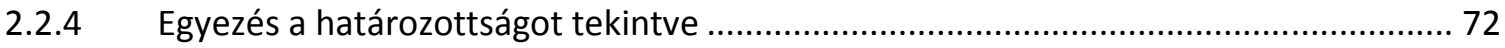

2.3 A hátravetett jelzői értelmező összetevőinek a vizsgálata .................................................. 73

2.3.1 A szerkezetben megjelenő melléknevek ........................................................................ 73

2.3.2 A szerkezetben megjelenő számnevek ………........................................................ 74

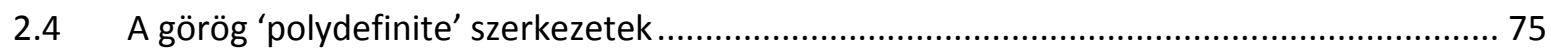

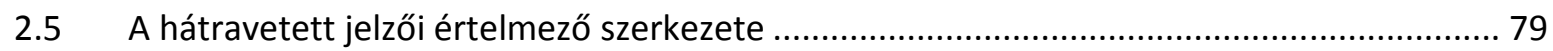

2.5.1 Ellenérvek a korábbi elemzésekkel szemben ................................................................ 80

2.5.2 A hátravetett jelzői értelmező elemzése ellipszisként .................................................... 82

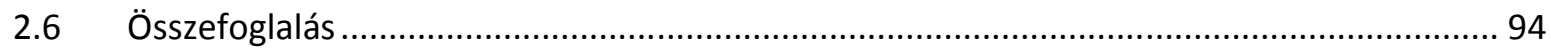

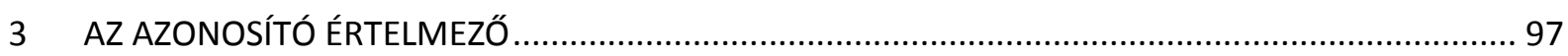

3.1 Az azonosító értelmező tulajdonságai ............................................................................ 97

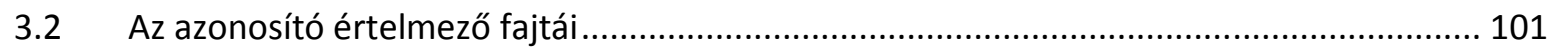

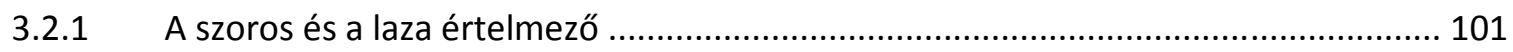




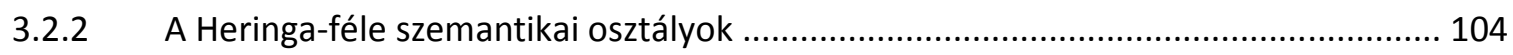

3.2.3 Az azonosító értelmező különféle csoportjai ............................................................. 114

3.3 Appozíció-jelölők az értelmezős szerkezetben ............................................................. 115

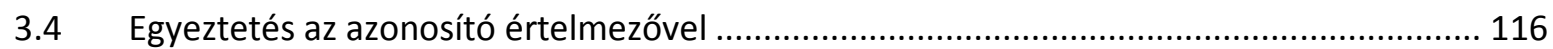

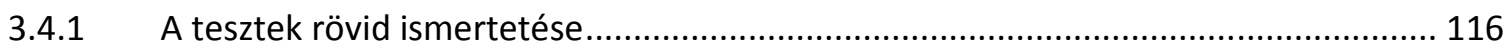

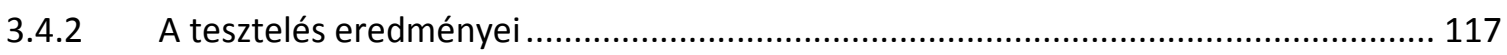

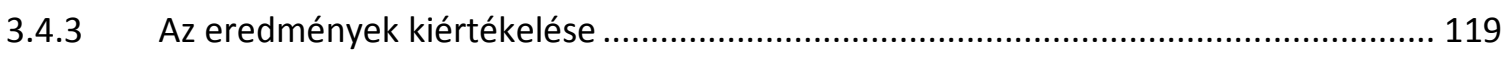

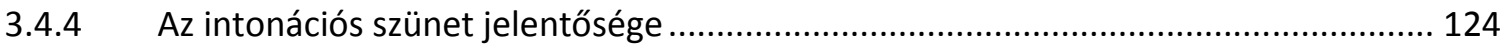

3.4.5 Egyeztetés a specifikációs és a predikációs értelmezővel........................................... 125

3.5 Az azonosító értelmező elemzése ................................................................................. 126

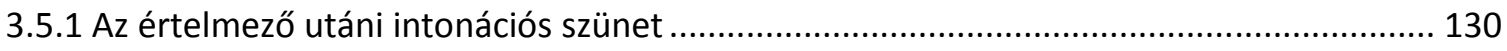

3.5.2 Az azonosítás és a tulajdonítás osztályába tartozó értelmezők elemzése................... 131

3.5.3 A bennfoglalás osztályába tartozó értelmező elemzése........................................... 135

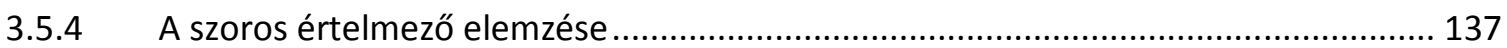

3.5.5 Egy komplex appozíciós konstrukció szerkezete........................................................ 139

3.6 Az 'én, a koronatanú' és a 'mi férfiak' szerkezetek elemzése............................................. 140

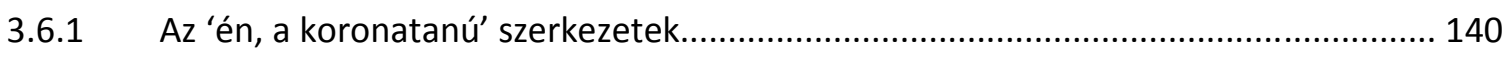

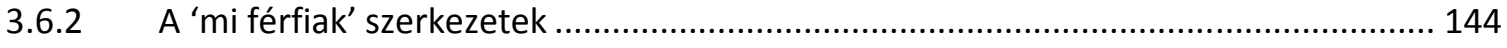

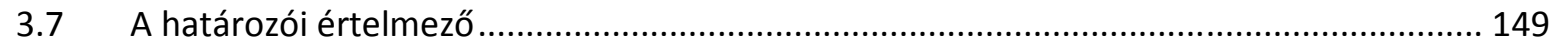

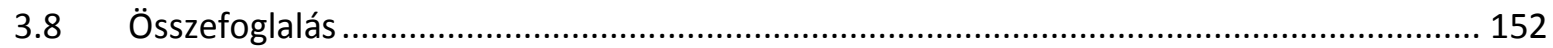

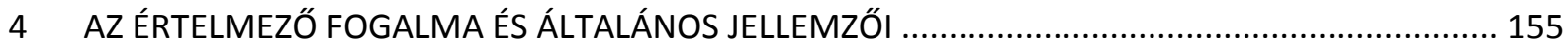

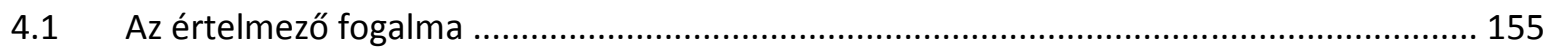

4.1.1 Az értelmezős konstrukció definiálása a jellemzői alapján .......................................... 155

4.1.2 Az értelmező definiálása a nyelvtani modulok felől .................................................... 160

4.2 Mi nem tartozik az értelmezők csoportjába?.................................................................. 162

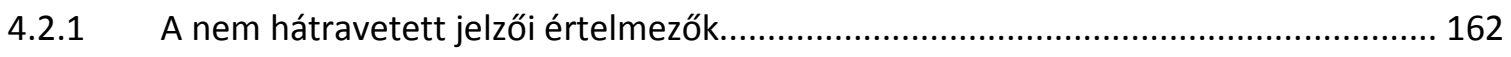

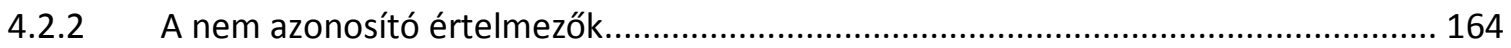

4.3 A hátravetett jelzői értelmező és az azonosító értelmező összehasonlítása........................ 166

4.4 Integrációs kontra „árvaházi” megközelítés a szerkezet elemzéséhez.............................. 167

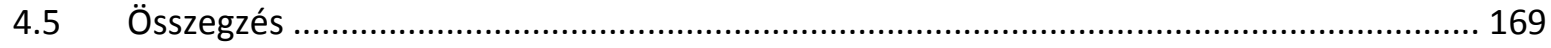

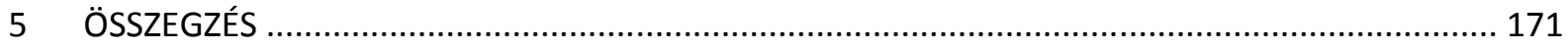

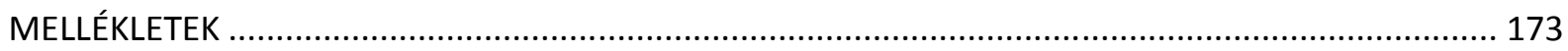




\section{BEVEZETÉS}

\subsection{A kutatás oka és célja}

A disszertáció témája - a magyar hagyományos terminológiával élve - az értelmezös szerkezetek szintaktikai szempontú elemzése a magyar nyelvben, mégpedig a generatív szintaxis elméleti keretén belül dolgozva. Hiányzik a magyar generatív irodalomból a magyar értelmezös szerkezetek alapos vizsgálata, ezért a disszertáció egyik fő célkitüzése ennek az ürnek a kitöltése.

A disszertáció célja egy átfogó elméleti szintủ elemzés kidolgozása a magyar értelmezős szerkezetekről, azon belül elsősorban a nominális értelmezős konstrukciókra koncentrálva. A vizsgált szerkezettel kapcsolatban felmerült egy komoly probléma: a leíró nyelvészeti munkákban nincs egységes álláspont arról, hogy a kérdéses konstrukciót alárendelésként (Tompa 1964, Rácz 1991), mellérendelésként (Szabó 1955; Antal 1964, 1977; Jakab 1977) vagy sajátos átmeneti szerkezetként (Balogh 1999) elemezzük. Dér (2001) az alárendelö és a mellérendelő viszonyt elvetve amellett érvel, hogy szószerkezeti szinten egy harmadik viszony is létezik: az azonosító/értelmezői viszony. Véleményem szerint a probléma oda vezethető vissza, hogy az értelmezős szerkezet egyes fajtáit - a hátravetett jelzői értelmezőt és az azonosító értelmezőt - egységesen próbálják meg elemezni, noha ez a két típus eltérő jegyeket mutat. Ahhoz, hogy minél pontosabb képet kapjunk ezekről a konstrukciókról, szükségesnek tartom a két típus külön-külön történő vizsgálatát és elemzését. Továbbá felmerült annak a lehetősége a kutatásaim során, hogy az értelmező ezen két fajtájától célszerü lenne megkülönböztetni egy harmadikat is - a határozói értelmezőt -, amely mindkét típustól eltérő jegyeket mutat.

A nemzetközi szakirodalomvizsgálata során egy újabb probléma adódott: a posztnominális pozícióban megjelenő mellékneveket - szemben a magyar nyelvtanokkal - nem sorolják az értelmezős szerkezetek alá (Bosque-Picallo 1996, Dürscheid 2002, Pysz 2009). Ebböl adódóan felvetődik a kérdés, hogy a magyar hátravetett jelzőt valóban besoroljuk-e az értelmezők közé. A disszertációmból nem szeretném kizárni a hátravetett jelzők vizsgálatát, de az azonosító értelmezővel való összehasonlítása még inkább megerősíti azt a hipotézist, hogy két különböző konstrukcióval állunk szemben, amelyekhez nem kell feltétlenül ugyanazt a szerkezetet rendelnünk. Az az oka annak, hogy a hátravetett jelzői értelmezők is részét képezik a dolgozatnak, hogy ezen a ponton nem szeretnék szembefordulni a leíró nyelvészet hagyományával.

A disszertációmban a következő kérdésekre keresem a választ: Mi az értelmező fogalma? Milyen fajtákat különböztethetünk meg a magyar értelmezös szerkezetek körében? Mi- 
lyen tulajdonságokkal rendelkeznek az egyes értelmezőfajták? Hogyan kapcsolódik az értelmezős szerkezet a mátrix mondathoz, illetve milyen szintaktikai eljárásokban hogyan vesz részt? Milyen szerkezeti elemzés rendelhető az egyes értelmezőfajtákhoz? Milyen kapcsolat van az értelmezők és a közbevetések között?

Kutatásom során arra a következtetésre jutottam, hogy az értelmező fogalmát úgy lehet a legpontosabban megadni, ha a nyelvtani modulok felöl közelítjük meg, és külön-külön megadjuk az egyes értelmezőfajták jellemzőit. Az értelmező általános fogalmát a következőképpen fogom meghatározni: Az értelmezős szerkezet két tagból áll, amelyek azonos grammatikai funkciót látnak el, az értelmezett szót módosítja, kiegészíti, pontosítja vagy leszűkíti az értelmező, és a két szerkezettag azonos referenssel rendelkezik (beleértve a magában foglalást is).

\subsection{A dolgozat felépítése}

Az első fejezetben a szakirodalmi hátteret fogom ismertetni, először azt mutatva meg, hogyan jellemezték a magyar leíró nyelvészek az értelmezős szerkezetet nyelvünkben az elmúlt száz évben. Ezután a nemzetközi szakirodalmi háttér rövid ismertetése következik, arra helyezve a hangsúlyt, hogy milyen eredmények születtek az utóbbi években.

A magyar értelmezős szerkezet két fajtáját - a hátravetett jelzői értelmezőt és az azonosító értelmezőt - külön-külön fejezetben fogom tárgyalni. A második fejezetben sorra veszem a hátravetett jelzői értelmező tulajdonságait, megvizsgálom a szerkezeten belüli egyezést, külön figyelmet szentelek annak a kérdésnek - a korábbi leíró nyelvtanokkal szemben -, hogy milyen melléknevek és számnevek jelenhetnek meg a szerkezeten belül. Összevetem a magyar hátravetett jelzői értelmezőt a görög 'polydefinite' szerkezetekkel, megmutatva a látszólagos hasonlóságok ellenére a két konstrukció különbségét. Végül pedig a szerkezeti elemzés során az ellipszis alkalmazása mellett foglalok állást, ellenérveket hozva fel a korábbi elemzési javaslatokkal szemben.

A harmadik fejezetben először az azonosító értelmező jellemzőivel foglalkozom, majd a fajtáit vizsgálom meg többféle csoportosítási szempont szerint. Fontos előrelépés, hogy - a hagyományos magyar leíró nyelvtanokkal szemben - a szoros értelmező létjogosultsága mellett érvelek a magyar nyelvben, rámutatva a nemzetközi példákkal való különbségekre is. Külön alfejezetet szentelek a kötőszók, az úgynevezett appozíció-jelölők vizsgálatának, beillesztve a megfigyeléseimet a nemzetközi eredmények közé. Kutatásom kiterjed az állítmánynak az alanyi, illetve tárgyi szerepben megjelenő azonosító értelmezős szerkezettel való 
egyeztetésére is, amelynek célja azon kérdés eldöntése, hogy a vizsgált konstrukcióban az értelmező alá- vagy mellérendelésként viselkedik a mátrix mondatba való beágyazása során. A szerkezeti elemzés során kizárok három megoldási javaslatot: egyrészt az appozíciós szerkezet lecsökkentett vonatkozói tagmondatként való elemzését, másrészt ellipszisként való felfogását, harmadrészt az értelmezős konstrukció RELATOR-os elemzését (Den Dikken 2006) a szerkezettagok között lévő predikatív viszonyra építve. A dolgozat újdonsága, hogy az azonosító értelmezőn belüli különféle fajtákhoz - azok eltérő szintaktikai, szemantikai tulajdonságai miatt - más-más szerkezeteket rendelek. Külön alfejezetben tárgyalom a személyes névmást mint értelmezett szót tartalmazó szerkezeteket. Ebben a fejezetben foglalkozom azzal a kérdéssel, hogy valóban szükséges-e megkülönböztetni a határozói értelmezőt a többi értelmezőfajtától.

A negyedik fejezetben definiálom az értelmezőt, először - folytatva a szakirodalmi hagyományt - a szerkezet jellemzői felöl közelítem meg a vizsgált fogalmat, majd egy újfajta megközelítést alkalmazva a nyelvtani modulok felől nézve adom meg az értelmező definícióját. Több oka is van annak, hogy ez a fejezet a disszertáció végére került: 1) Problémák mutatkoztak a szakirodalmi háttér feltárása során az értelmezős szerkezet pontos definiálását illetően, amelyet tovább nehezített az a tény, hogy a magyar értelmező fogalmát nem fedi le a nemzetközi szakirodalomban használatos definíció. 2) Az értelmező fajtáinak, tulajdonságainak ismertetése, egyes korábbi állítások módosítása és kiegészítése vezet el oda, hogy az eddigieknél pontosabb fogalmat rendelhessünk az értelmezős szerkezethez. 3) Ebben a fejezetben veszem sorra azokat a példákat, amelyeket bizonyos kritériumok alapján szeretnék kizárni az értelmezők köréből, de ehhez újra csak szükséges az előző két fejezet eredményeire, konklúzióira támaszkodni.

Ebben a fejezetben kerítek sort arra is, hogy állást foglaljak a szakirodalomban fellelhető két megközelítés - az ,árvaházi” és az integrációs elmélet - egyike mellett. Amellett fogok érvelni, hogy az „árvaházi” megközelítésre épül azon példák szerkezeti elemzése, amelyekben az értelmező után is kell intonációs szünetet tartani, míg az értelmező utáni szünet nélküli példák esetében egy integrációs elemzésre fogok támaszkodni.

A disszertációt egy összegzéssel zárom, összegyüjtve a kutatásom új eredményeit, és rámutatva a további vizsgálatok lehetséges irányára.

A Mellékletek című rész tartalmazza az elvégzett teszteket, a grammatikai ítéletek megoszlását összegző táblázatot, a rövidítések feloldását, továbbá a magyar szépirodalmi példák lelőhelyének pontos adatait. Legvégül a Hivatkozások rész következik. 
A terminológiai használatot tekintve elörebocsátom, hogy noha sem a hátravetett jelzői értelmező, sem az azonosító értelmező terminust nem tartom a legmegfelelőbbnek, de a hagyományt folytatva ezeket az elnevezéseket fogom használni a disszertáció során. Továbbá kizárólag az azonosító értelmező szinonimájának tartom a - nemzetközi szakirodalomban is használatos - appozíció (apposition) terminust.

Két technikai megjegyzés: 1) Minden fejezetben elölről indítom a példák sorszámozását, mivel igen sok adattal dolgozom. Ahol nincs feltüntetve az adatok származási helye, ott általam generált példák találhatók. 2) A magyar szépirodalmi példák pontos lelőhelyét mindig az adatok sorában adom meg. 


\section{SZAKIRODALMI HÁTTÉR}

\subsection{A magyar nyelvészeti háttér}

Először a magyar szakirodalmat fogom ismertetni, bemutatva, hogy az elmúlt száz évben milyen leíró nyelvészeti munkák születtek az értelmezős szerkezettel kapcsolatban, milyen eredmények tulajdoníthatók az egyes kutatóknak, és milyen szerkezeti elemzéseket rendeltek a magyar értelmezős konstrukcióhoz. Az áttekintésből hiányzik a hazai generatív irodalom ismertetése, mivel nem találtam olyan tanulmányt, amely a generatív szintaxis eszköztárára építve részletesen foglalkozna a magyar értelmezős szerkezetek vizsgálatával.

\subsubsection{Simonyi Zsigmond (1913)}

Simonyi Zsigmond száz évvel ezelött a következőképpen definiálta az értelmezőt: „Az értelmező abban különbözik a közönséges jelzőtől, hogy a jelzett szóval nem egyesül olyan szorosan, hanem mint utólagos kiegészítés, értelmezés, részletezés járul hozzá, külön szólamban, külön hangsúllyal, s az írásban rendesen vesszö választja el tőle" (Simonyi 1913: 113).

Az értelmező használatát azzal indokolja, hogy általában egy kevésbé fontos körülményt fejez ki, vagy pedig egy olyan gondolat, amely utólag jut a beszélő eszébe, vagy pedig szándékosan hagyja utoljára.

Simonyi (1913: 114) Verseghy Ferencre és Lehr Albertra hivatkozva ${ }^{1}$ azt állítja, hogy a nyelvészek „rövidített vagy pregnáns mondatot látnak az értelmezőben”, és az értelmező mondatértékét egyes kötőszavak megjelenése is felerősíti (1). Az értelmező sokszor vonatkozói mondat értékével bír, (2a) helyett (2b) is mondható. Az (1)-es példák (Simonyi 1913: 115)-ből, míg a (2)-es adatok - idézve Simonyi (1913: 114)-ben - Verseghy (1816-17, 2: 125)-ből származnak.
a. hozzál almát, szépet
b. hozzál almát, de szépet ám
a. bosszút állott rajta, hallatlant
b. bosszút állott rajta, mely hallatlan volt

(2)

\footnotetext{
${ }^{1}$ Verseghy Ferenc 1816-17. Analytica institutionum linguae hungaricae. Pars I. Etymologia... Pars II., Syntaxis linguae hungaricae. Pars III. Usus aestheticus. Három kötet (névtelenül), Buda.

Lehr Albert 1882. Toldi. Költő̋i elbeszélés. Írta Arany János, nyelvi és bő magyarázatokkal ellátta. Budapest
} 
Simonyi sorra veszi az értelmező használatának főbb eseteit, kihangsúlyozva, hogy azok nem mindig válnak el élesen egymástól.

a) magyarázat: az értelmezett szóhoz hozzácsatoljuk a személynek vagy a dolognak egy másik, pontosabb nevét (főnevet) vagy egy jellemző tulajdonságát (melléknevet).
a. Van a léleknek egy erös szava, /A nagyravágy. [Madách: Az ember tragédiája]
b. hazánk gyöngye, a Balaton
[Simonyi 1913: 115]
c. Nem vagy mai gyermek, se leányzó gyenge
[Arany: Buda halála]
d. Uram, azt is látod, az pogány töröknek miként vásik foga, az hitetlen ebnek.

[Zrínyi: 2: 72]

e. Azonban hamar egyéb tárgyat vett megbámulni valót.

[Vas G.: Nagy Idők]

b) fokozás: a melléknévi értelmező szerepe gyakran a fokozás, nagyítás, valami meglepőnek a kifejezése.
a. Adjon tanácsadót, jobbat, mint én valék.
[Arany: Toldi estéje 1: 29]
b. Az arcán tüzrózsák égtek, perzselök, észveszejtök.
[Móricz: Hét krajcár]
c. Erröl írást tudom sokat hallhattok.
[Tinódi]
d. Másutt is kapott az oly uitést eleget.
[Arany: Toldi estéje]

Érdekes példaként emeli ki Simonyi azt az esetet, amikor a mennyiségre utaló szó kerül előre, és a főnév jelenik meg az értelmezői pozícióban (5). ${ }^{2}$
a. Szegény hazám te, neked kevés van ilyen csillagod.
[Petőfi: A hazáról]
b. Küldött már hatszázat törököt pokolban
[Zrínyi: Szigeti veszedelem 5: 50]

c) szükséges értelmező: mind a jelzett szót, mind az értelmezőt külön-külön kiemeljük, ilyenkor nem tehető vessző a szerkezettagok közé, és általában az értelmezett szó ellentétben van egy másik értelmezett szóval. ${ }^{3}$ A (6)-os adatok származási helye Simonyi (1913: 118).

\footnotetext{
${ }^{2}$ Az (5)-ös példákhoz hasonló adatokat a 4.2.1 pont alatti alfejezetben ki fogom zárni az értelmezők köréből.

${ }^{3}$ Simonyi (1913: 118) lábjegyzetben megjegyzi, hogy Brassai (1863: 241) szerint az ilyen értelmező valójában nem jelző, hanem „tulajdonítmány”, vagyis névszói állítmány.
} 
b. Idöm sok van, de pénzem kevés.

d) Az értelmezett szóra esik a főhangsúly, és az értelmező gyenge nyomatékot visel magán. A (7b) adat Simonyi (1913: 118)-ból származik.

(7) a. Nem tudom, szerencse-e nagyobb, vagy költöi érdem, ha sikerül a képzelet világából oly lakot idézni elö...

[Arany: Próz. 296]

b. Kukorica sem termett elég, nemhogy búza.

Simonyi idegenszerünek, németes használatnak véli a jelző hátrahelyezését abban az esetben, amikor csak a jelzőt kell hangsúlyozni, illetve ha az egész szerkezetet egységesnek kell vennünk (8). ${ }^{4}$

a. Nietzschét, a müvészt, s Nietzschét, a filozófust levezettük a filológusból.

[Babits: Nyugat 4. évf. 2: 62]

b. Én Kazinczyt, a szabadkömüvest akarom elétek állítani... S Kazinczyt az írót nem választhatjuk el Kazinczytól, a szabadkőmüvestöl.

[emlékbeszéd]

Simonyi egy külön alfejezetben tárgyalja a névmások szerepét az értelmezős szerkezetekben, külön-külön felsorolva az egyes névmásokat, és megvizsgálva a hozzájuk kapcsolódó példákat.

a) A mutató névmások kapcsán Simonyi megjegyzi, hogy ilyenkor gyakran mindkét fogalmat külön-külön ki kell emelni (9a). A (9c-f) példákról azt állítja, hogy az értelmező partitív értelmü. A (9e) Simonyi (1913: 121) saját példája.
a. Annyit kellene pénzt is rendelni, hogy megérnék vele.
b. Olyat rikoltottam volna egyet.
c. Ezek mindenik a Mahomed vallását követték.
d. Ezek akármelyik béfér.
e. Csak kenyeret adott, azt is keveset / azt se eleget.
f. Egye meg a pondró, az is a nagyobbik.

[Zrínyi: Áfium]

[Nyr. 5: 221]

[Mikes TLev. 204]

[Nyr. 2: 39]

[Dugonics Péld. 2: 34]

\footnotetext{
${ }^{4}$ A (8)-asban látható adatokat szoros értelmezőként fogom elemezni, és a szerkezet egységét azzal jelölöm, hogy az értelmezett szó és az értelmező közé nem teszek vesszőt (lásd a 3.2.1 pont alatti részt).
} 
A mutató névmás az értelmező szerepét is betöltheti Simonyi szerint, és ezt az alábbi példákkal illusztrálja (10). ${ }^{5}$ A (10c) példa származási helye Simonyi (1913: 125).

(10) a. Hazudni azt tudnak.

[Népszava, S. Zs. 124]

b. A lovat is azt ütik, aki a legjobban húz.

[Kovács: Közmondások 92]

c. bort annyit ittak, hogy egészen eláztak

b) A határozatlan névmás esetében hoz régi példákat (11a), megmutatva, hogy azt a saját korában (tegyük hozzá, hogy napjainkban is) már milyen formában használják (11b). A ki-ki páros határozatlan névmásnak a partitív értelmezői használatára is hoz példát (11c). A (11a, b) adatok Simonyi (1913: 125)-ben találhatók.
a. valamit jót
b. valami olyat
c. A kapu elött megharcoltak, sokat kit levágtak s kit elfogtak bennek.

[TörtTár. 1908. 471]

„A határozatlan névmásnak értelmezője legtöbbször (a) más vagy egyéb, vagy viszont (b) emezeknek az értelmezője a határozatlan névmás" (Simonyi 1913: 126). Erre a szerkezetre a következő példákat hozza (12).

b. Akár aludjam, akár vigyázzak, akár valamit egyebet tegyek.

[VirgK. 115]

c. Kacagtam rajta, mert holmit egyebet juttata eszembe, amit töle más esetekben hallottam.

[Kaz. L. Toldy kiad. 1: 363]

d. A biblia könyvek nem említenek más valakit.

[Fal. 53]

c) Simonyi külön veszi a tagadó névmásokat. Itt is megkülönbözteti a régebbi alakokat (13a) saját korának az újabb alakjaitól (13b). A (13)-as adatok Simonyi (1913: 127) példái.
a. senkit idegent
b. semmi mást

\footnotetext{
${ }^{5}$ Ezekre a példákra a 4.2.1 pont alatti alfejezetben még vissza fogok térni.
} 
d) Külön hoz példákat olyan szerkezetekre, amelyek a minden, egyéb és más értelmezőket tartalmazzák (14). ${ }^{6}$
a. Fegyverviselő nép mindenki felüljön!
[Arany: $\mathrm{BH}]$
b. Elébb teljesíti vala meg mindennél egyébnél.
[MargL. 36]
c. Egy képet írtanak mást.
[Hall. HHist. 2: 46]

e) Simonyi szerint a kérdő névmásoknak is lehet értelmezőjük (15a, b), de értelmezőként (15c) már ritkábban fordulnak elő. A bosszankodó, olykor tréfás kérdéseket is idesorolja (15d), rámutatva, hogy azokban ragozható a szerkezetnek mind a két tagja, vagy olykor csak az értelmező (15e). A (15b-e) adatok Simonyi (1913: 128-129)-ben találhatók.
a. Mit kellessék legjobbat török hasznára cselekedni?
b. Mi van látni való?
c. Hát kalapot milyent vettél?
d. Mi a fene? / Mi a manó? Mi az ördög?
e. Mit az ördögöt? / Mi a fenének?

[Zrinyiász 8: 25]

f) A vonatkozó névmások tárgyalásánál Simonyi újra hoz példákat a régi (16a) és a mai (16b) nyelvből. Külön megemlíti, hogy még névmás is lehet az értelmezője a vonatkozó névmásnak, mégpedig leggyakrabban a maga névmással találkozhatunk az ilyen szerkezetekben (16c). A (16)-os példák származási helye Simonyi (1913: 130-131).
a. amit szépet látunk
b. ami újat hallottam
c. Az öccsétöl kért pénzt, akinek magának se volt egy fillérje se.

g) A maga névmás kétféle sorrendben szokott megjelenni az értelmezős szerkezetekben, s minden esetben a második elemre esik a főhangsúly (17). „Ez a szerkezet szakasztott mása az 'ez a király’ féle szerkezetnek, s a kettőnek történeti fejlődése is egészen egy nyomon jár. Mai nyelvünkben maga a király is - legalább rendesen - szétválaszthatatlan szórendi egység, mint

\footnotetext{
${ }^{6}$ A (14b) példa kapcsán Simonyi (1913: 128) megjegyzi, hogy ma a minden egyébnél alak a használatos.
} 
ez a király, de a régibb nyelvben éppúgy megtürt közbeszúrt kifejezéseket, leginkább kötőszókat, de néha még az igét is" (Simonyi 1913: 131-132, a (17a-c) adatok is itt találhatók).
a. maga a király
b. a király maga
c. öneki magának
d. Jézust őmagát találák.

[ Helt. UT. R4]

h) A személyes névmásokkal kapcsolatban Simonyi megemlíti, hogy főnévi és melléknévi értelmezőjük is lehet (18a-c). Ritkán fordul elő, de a személyes névmás is szolgálhat értelmezőként (18d-f). A (18a, b) példák Simonyi (1913: 132)-ből származnak.
a. Én szerencsétlen, mit cselekedtem!
b. Mit csinálsz te bolond?
c. Hát mi bünösök hogy ne félnénk?
[Mikes]
d. Szegény hazám, szegény hazám te, neked kevés van ilyen csillagod-
[Petöfi]
e. Férfiak mi is hamar megértök, de az asszonyféle szeret mindenbe kötelözködni.

[Kovács P. Fars. kaland 57]

f. Áldott vagyok, méhed gyümölcse, én!

[Komjáthy J.]

i) Simonyi az egyéb esetek között tárgyal néhány - szerinte - érdekes esetet. Ilyen a szegény melléknév értelmezői használata (19a), illetve amikor az értelmező elé odaértjük a személyes névmást (19b, c).
a. Bolond ám ö szegény.
[Decsi: Adag. 161]
b. Dalold, madár, aztat a bús verseket.
[Népk. gy. 2: 180]
c. Nincs mihez folyamodnunk, szerencsétlen fejünknek.

[Báróczi, Dusch 1. erkölcsi levelében]

Simonyi egy külön alfejezetben tárgyalja a számnévi értelmezők csoportját. A felsorolt példák azt mutatják, hogy nemcsak a tőszámnevek, hanem a sorszámnevek is megjelenhetnek értelmezőként (20). A (20a, b) példák származási helye Simonyi (1913: 134). 
(20) a. A pun háborúban, a másodikban, Hannibálé volt a föszerep.

b. Tettéért kemény büntetés sújtotta, háromszoros.

c. Török három ezer elveszté életét.

[Zrínyi: Szigeti veszedelem]

d. Adok érte jó forintot százat.

[Arany]

Simonyi az értelmező jelzőt tárgyaló fejezet végén található jegyzetben hoz példákat a „határozó alakú értelmezőkre” (21). A (21b-d) példák Simonyi (1913: 135)-ben találhatók.

(21) a. Egész úton haza felé azon gondolkodám

[Petöfi]

b. benn a házban

c. itt a szobában

d. arra hátra

\subsubsection{Károly Sándor (1958)}

A Károly (1958) által feltett kérdések egy része ma is aktuális erővel bír, és az elmúlt fél évszázad során sem sikerült azokat teljes mértékben megválaszolni: Jelző-e az értelmező? Alárendelésként vagy mellérendelésként elemezzük az értelmezős szerkezetet? Mi a különbség az értelmező hazai és külföldi felfogása között? Állhat-e elöl az értelmező?

A hagyományos grammatika által megkülönböztetett két típus, a jelzős érintkezés ( $a l$ mát, pirosat) és a jelzős azonosság (Mátyást, a királyt) kapcsán már Károly (1958: 18) is kiemeli, hogy a kettő között „lényeges különbség van tartalmi szempontból, illetőleg egészen másképp viszonyul az egyik az ismert mondatrészekhez, mint a másik. Az egyiket a közönséges jelzőtől csak a laza szerkezet különbözteti meg, a másik tartalmilag is más típus.”

Az értelmezős szerkezet általános jellemzőit tárgyalva a tagok közti szünettel kapcsolatban Károly (1958) egymásnak ellentmondó megállapításokat tesz. Egyrészt azt hangsúlyozza, hogy „az összes értelmezős szerkezetre kötelező érvénnyel jellemző a laza szerkesztésmód, tehát a tagoknak szünettel való elkülönülése, külön hangszakaszban való elhelyezkedése” (uo. 18.). Másrészt ő maga is hoz olyan példákat (Károly 1958: 41), amelyekben nincs, vagy csak igen rövid szünet figyelhető meg (22), illetve kiemeli, hogy a szünet eltünése vagy megrövidülése esetében „már nem tipikusan értelmezős szerkezettel van dolgunk” (uo. 19.).
a. vért keveset onta
b. Van Petöfinél ehhez hasonló eset több is

[Arany: Buda halála]

[Horváth: Verstan] 
c. Van szabadvers rímtelen, s rímes is

[Horváth: Verstan]

d. Tiszta rímje már inkább van egytagú.

[Horváth: Verstan]

e. lámpa is volt kettö, de asztalunk nem volt hozzá egy se

[Veres]

f. mindenkinek van gondolata temérdek

[Csillag 1952: 538]

Az értelmezős szerkezeten belül Károly négy típust különböztet meg: az azonosító jelzőset (23a), a jelzőset (23b), a sajátos azonosító szerkezetet (23c, d) és a határozósat / tárgyasat (23e). A (23)-as adatok Károly (1958: 18)-ból származnak.
a. Budapesten, a fövárosban
b. az asztal, a zöld
c. benn, a szobában
d. termelni, azaz javakat elóállítani
e. iszik, vizet

A (23e)-t mindenképpen ki kell zárnunk az értelmezők köréből, hiszen a szerkezetből hiányzik az értelmezett szó, az intonációs szünet megjelenése nem elégséges feltétele annak, hogy értelmezős konstrukcióról beszéljünk. Balogh (2003: 465) hasonló megfontolás alapján lazán hátravetett mondatrésznek nevezi az ilyen összetevőket.

A további jellemzők között megemlíti Károly, hogy az értelmező a sorrendet tekintve mindig a második tag. A szerkezettagok közé olykor más elemek is beékelődnek, ilyenkor nagyobb az értelmező függetlenedése, predikatív ereje és mondatértéke (24). A (24a) példa származási helye Károly (1958: 19).
a. Ezután túrós csusza következett, ízes, tejfölös.
b. Más faj állott a kihúnyt helyére, / Gyönge fövel, romlott, szívtelen.

[Kölcsey: Zrínyi dala]

Az egyeztetést vizsgálva Károly megállapítja, hogy vannak látszólagos kivételek az esetegyeztetés és a számegyeztetés alól: a birtokos személyjeles tárgy tárgyrag nélkül is megjelenhet (25a), a határozóragok egyezhetnek csak az irányt tekintve (25b), számnév megjelenése esetén pedig értelmi egyeztetés történik (25c). 
[Ady: Elbocsátó szép üzenet]

b. Ök ezalatt mindnyájan kiléptek a tornácra, a nagy kerek s üvegezett térbe

[Móricz: Rokonok]

c. Egymásra néz a sok vitéz, / A vendég welsz urak

[Arany: A walesi bárdok]

Károly amellett foglal állást, hogy az érintkezést kifejező értelmező mind a fogalmi viszony, mind a mondatfunkció szempontjából alárendelés. Az azonosságot kifejező értelmezőt a fogalmi viszony szempontjából mellérendelésnek, míg a mondatfunkció felől nézve alárendelésnek tartja. Az alárendelés esetében úgy gondolja, hogy az egyik elem feladata a másik elemnek a mondat szerkezetébe való bekapcsolása. Tehát az értelmezőt az alárendelő szerkezetek, azon belül a jelzők közé sorolja, megjegyezve, hogy az azonosító értelmezőnek a mellérendelő viszonyhoz is van köze, mivel a szerkezet két tagja ugyanolyan viszonyba lép egy harmadik taggal.

A nemzetközi szakirodalomban használatos appozíció fogalma kapcsán Károly (1958: 23) megjegyzi, hogy ,az tartalmilag szűkebb kategória, mint a mi értelmezőnk, mert csak a főnévi jelzős szerkezetekre korlátozódik, de mondatfunkciós és formai szempontból tágabb, mert nemcsak a laza szerkezeteket foglalja magába, hanem az összes főnévi jelzős szerkezeteket”. A másik fontos eltérés, hogy a szorosabb appozíció a „külföldi” szakirodalom szerint megelőzheti az értelmezettet, s csak a lazán kapcsolt appozíció áll mindig a második helyen. ${ }^{7}$ Az azonosító appozíció nem értelmezős jelzős megfelelőjének tartja Károly az alábbi példákat (26). A (26)-os adatok Károly (1958: 29)-ben találhatók.
a. Bodri kutyám
b. a híres Kelemen kovács

Az azonosító értelmezők között Károly olyan példákat is feltüntet - minden különösebb magyarázat nélkül -, amelyek első pillantásra a hátravetett jelzői értelmezők közé tartoznának. Vegyük sorra ezeket az adatokat (27). A (27c, d) példák Károly (1958: 31)-ben találhatók.

\footnotetext{
${ }^{7}$ Károly (1958: 23) a német nyelvből hoz példákat a „szorosabb” appozícióra: Professor Müller ('Müller professzor'), der Monat Juli ('a júliusi hónap'). Ezekkel kapcsolatban csak annyit jegyez meg, hogy a magyar példáktól (Duna folyó, Mátyás király) eltérő intonációval rendelkeznek, amelyek nem tekinthetők értelmezős szerkezetnek.
} 
a. Shozzá Noémi még, a kisebbik [gyermek], rosszalkodott [Babits: Halálfiai]

b. Sokan voltak ott, nagyon elökelöek

[Ady: Összegyüjtött novellái 119]

c. Melyiket válasszam? - Ezt, a nagyobbikat.

d. Az maradjon ott, a széles rámájú [kép].

e. És föllángol e táj, e néma, lomha?

[Juhász Gyula]

A (27a) példa esetében egy nem korlátozó értelmező jelenik meg, ami a szövegkörnyezetből derül ki: Noémit a kisebbik gyermekként azonosítjuk, és nem arról van szó, hogy több Noémi közül beszélünk a kisebbikről. A (27b-d) adatokban az értelmezett szó egy névmás, amelynek nem lehet jelzője, így ezekben a példákban fel sem merül a hátravetett jelzői értelmező lehetősége. (Ez megerősíti az elliptikus felfogást a hátravetett jelzői értelmező esetében, amely mellett érvelek a 2. fejezetben.) A (27e) példa azonban feltehetően tévedésből került az azonosító értelmezők közé, az e demonstratívum jelenléte a néma melléknév előtt nem elegendő magyarázat, főleg annak tükrében nem, hogy Károlynak (1958: 40) egy későbbi, hasonló jellegü példája a jelzői értelmezők között szerepel (28).

(28) Hat éve élte Rozál mellett gondtalan életét, ezt a belsõ valójától mégiscsak idegent.

[Jankovich: Bün és bocsánat 94]

Az azonosító értelmezők között Károly felsorol olyan példákat is, amelyekben kontrasztív topik jelenik meg (29). Ezeket az adatokat mindenképp kizárnám az appozíciók köréből, hiszen a mutató névmás nem képes betölteni az értelmezői szereppel együtt járó pontosító, szükítő funkciót. Erre a kérdésre a 4.2.1 pont alatti alfejezetben még vissza fogok térni.

a. Mátyás, az itt maradt

b. Vadat és halat, azt látok én

c. éjfélig csavarogni, kajtatni, ezt nem teszi meg rendes ember
[Arany: V. László]

[Arany: A walesi bárdok]

[Szabó: 227]

Az azonosító értelmezők között tárgyalja Károly (1958: 32) a kérdő névmást tartalmazó szerkezeteket (30). A (30b) példa itt is első pillantásra hátravetett jelzői értelmezőnek tünhet, de mivel a kérdő névmásnak nem lehet melléknévi jelzője, újra csak egy olyan azonosító értelmezőt kell itt feltételeznünk, amelyben a szerkezet második tagjából egy ellipszisnek köszönhetően hiányzik a főnévi fej (Mit láttál érdekes [dølg@]-t?). A (30)-as adatok Károly (1958: 32)-ből származnak. 

a. Ki van itt jó munkás?
b. Mit láttál érdekeset?
c. Szépet mit láttál?

A személyes névmásokra hozott példák között az alábbiak szerepelnek (31), de ezeket is szükséges további vizsgálatok alá vetni. A (31a-c) adatok Károly (1958: 33) saját példái.
a. mi, e ház lakói
b. én, Nagy Péter
c. mi férfiak
d. Laci te, / Hallod-e
e. ti welsz ebek

[Petőfi: Arany Lacinak] [Arany: A walesi bárdok]

A (31d) példát kizárnám az értelmezők köréből, hiszen itt egyértelműen megszólításról van szó. A többi példára a 3.6 pont alatti alfejezetben fogok kitérni.

Károly szerint a maga névmás is megjelenhet az értelmezős szerkezetben, mégpedig visszaható névmásként (32a), nyomatékos személyes névmásként (32b), illetve 'egyedül, magában’ jelentésü névmásként (32c), amelyet határozószónak is lehetne venni. A (32a) példa származási helye Károly (1958: 33).
a. Megismerte magát, a küszködö embert.
b. magával Rózsa Sándorral találkozott a kukoricásban
c. az asszony maga rendelkezik a vagyonával
d. A falból magából egyáltalán semmi sem látszott.

[Móricz: 209]

[Móricz: 245]

[Móricz: 159]

A (32c)-ben látható maga névmást éppen azért kell kizárnunk az értelmezők köréből, mert itt határozó szerepét tölti be. A (32b, d) adatok azért érdekesek, mert nem választja el intonációs szünet a szerkezettagokat. Ezekben a példákban a visszaható névmás inkább egy nyomatékosító elemnek tűnik, nem pedig értelmezőnek.

A mind névmás megjelenése az értelmezős szerkezetben újabb problémákat vet fel (33). A (33)-as példák Károly (1958: 34)-ből származnak.
a. Elhozta a könyveket mind.
b. A vándorló madarak mind elköltöztek. 
Balázs János (1951), Simonyi (1895: 649) és Gombocz (1951: 50) összefoglaló határozószónak tartja a mind-et az ilyen értelmezőszerü helyzetekben. A mind rendszerint nem különül el szünet által attól a mondatrésztől, amelyre vonatkozik, ezért ha határozónak tartjuk, nem tekinthetjük értelmezői formájúnak. „Ha jelzőnek tekintjük, akkor szűkebb értelemben is lehet értelmező, de csak olyan, amelynek a formája nem mutatja tisztán a laza szerkesztésmódot. Jelző azonban csak úgy lehet, ha főnévi, illetőleg melléknévi (számnévi) szófajisága van. Ebben a tekintetben pedig egyetértünk Hámori Attilával, aki a mind főnévi, illetőleg melléknévi jelentésének az igazolására is gondot fordított (i. h. 144). Helyes tehát, hogy Hámori a jelzői funkciónak is teret szán, s hogy emellett a határozói funkcióval is számol, hogy tehát a főnévi, melléknévi jelentést is, meg a határozószói jelentést is megengedi.” (Károly 1958:35)

Károly Hámorival ellentétben nem választaná el élesen a határozószói és melléknévi, illetőleg főnévi jelentést, valamint az ezekkel összefüggő határozószói és jelzői funkciót. Az alábbi példához háromféle jelentést rendel (34). A (34)-es példák Károly (1958: 35)-ből származnak.

(34) A sok pásztor mind muzsikál.

a. A sok pásztor egytöl egyig, a maga összességében muzsikál. (határozószó és határozó)

b. A sok pásztor, az egész összesség muzsikál. (főnév és jelző)

c. A sok pásztor, az összes muzsikál. (melléknév és jelző)

Ha a mind ragot kap, akkor értelmezőnek tekintik (35). A (35)-ös adat Károly (1958: 36) saját példája.

\section{A húst mindet megette.}

Károly a mind-es példákat nem tipikus értelmezős szerkezetnek tekinti, amelyekben a mind „általában követi azt a főnevet, amelyre vonatkozik, és szinte kivétel nélkül mindig hangsúlyosabb annál. Szünet általában nincs kettejük között” (Károly 1958: 36).

Ritkán szünet is van (36a), illetve a mind is lehet értelmezett (36b). A (36a) példa Károly (1958: 36)-ban található.

a. Hozd el a barátaidat, mindet!

b. Adélka volt gyermekkorában a család kedvence..., akiért mind készek lettek volna meghalni, a testvérek.

[Móricz: 95] 
Károly a mint kötőszós állapothatározót is az értelmezők közé sorolja. Ezt a típust azért tartja problémásnak, mert a mint átmenetet képez a mondat és a mondatrész között, illetve a határozó és a jelzö között, ha mondatrésznek tekintjük. A (37)-es adatok származási helye Károly (1958: 37-38).
a. Üdvözölheted mint új elnököt.
b. Mint a vállalat legjobb dolgozóját jutalmazták meg, Szabót.

Bár (37a)-t Károly értelmezős szerkezetnek tartja, amelyben az értelmezett tárgyat elhagytuk, (37b)-ben pedig Szabó egy ki nem tett névmás értelmezője, Károly mégis inkább a határozókhoz közelíti ezt a típust arra hivatkozva, hogy szerkezetileg-formailag nem ugyanúgy viszonyul a mondat állítmányához, mint a másik főnévi tag.

A jelzős értelmező ismertetése során Károly megjegyzi, hogy az teljesen megfelel a nem értelmező jelzőnek, de nem mutatja meg, hogy miben és hogyan.

(38) a. az egész pusztát nevezhetetlen gyászos ünnepélyesség töltötte el, a fákból, házakból, légbỏl, az emberek arcáról egyaránt szüntelenül áradó

[Jankovich 64]

b. Nem mindennapi szerelemmel, hanem továbbra is azzal a templomban eredettel szerettem, midőn az oltár elött megpillantottam.

[Jankovich 174]

c. Hejh, bús évek voltak, / Véresek, lihegök, / S még sem voltak rosszak

d. langyos éj volt, nesztelen, halotti-csöndes

[Kosztolányi]

Károly megvizsgálja, hogyan lehet a szerkezetet hangsúlyozni. Három típust különböztet meg.

A) Az értelmező a hangsúlyos (39-40). A (39a-d) adatok Károly (1958: 42) saját példái.
a. Tojást tízet végy!
b. Húst keveset egyél!
c. Cipöt milyet vegyek?
d. A könyvet valamennyit elhoztam.
e. Ezüsttücsök milljom dongott.
f. Amellett tiszta rímje is sok van.

[Csillag 1952: 556] 
Sokszor szembeállító értékkel bír ez a szerkezet (40). A (40a, b) példák Károly (1958: 42)-ből származnak.

(40) a. Halat sokat meg tud enni, de húst keveset.

b. Szarvast egyet se lött

c. Magyar és antik formát keveset, nyugatit, kivált jambusit, annál többet használt.

[Horváth: Verstan 171]

B) Az értelmezett szó a hangsúlyosabb (41). A (41a-e) példák származási helye Károly (1958: 42), míg (42f) Simonyi (1913: 118)-ban található.
a. Tojást végy tízet!
b. Gyümölcsöt egyél sokat!
c. Bort ivott sokat.
d. Tojást se végy tízet!
e. Tojást se tízet végy!
f. Kukorica se termett elég, nemhogy búza.

C) Az állítmány a hangsúlyos (42). A (42a, b) adatok Károly (1958: 42)-ben találhatók.
a. Tojást vett tízet.
b. Ilyen embert nem találsz még egyet.
c. a cselédeknek nemigen van soknak kimenőjük [Tersánszky: Kakuk Marci 111]

Károly olyan szerkezeteket is megvizsgál, amelyekben látszólag fordított sorrend jelenik meg, gyakoribbnak tartva ezt a típust a régebbi korokban. „A hangsúlyos melléknév, számnév előbb van, mintegy értelmezettként, de ennek a hangsúlyozási egységébe olvad bele a főnév szünet nélkül. Ha beszélhetnénk arról, hogy elöl is állhat az értelmezö, akkor ez volna az a típus. De inkább úgy lehetne felfogni e szerkezetet, mint tömör szerkezetet, előrevetett jelzővel: a melléknevet erősen ki akarjuk emelni, ezért rögtön utána nem a főnevet tesszük, hanem az állítmányt.” A (43a, b) adatok Károly (1958: 42-43) saját példái.

(43) a. Akármennyit elköltenék én pénzt.

b. Sokat akarok fogni lepkét. 
Simonyi szerint ez a szerkezet a rendes jelzői szórend analógiájára alakult (i. m. 117), de Károly nem ért egyet ezzel, szerinte a szerkezet „,úgy jön létre, hogy a mondat kimondásának kezdetén a melléknévvel kifejezett tulajdonság van a beszélő tudatának az előterében, mint fontos mondanivaló, s inkább csak a hallgató, a világos érthetőség kedvéért közöltetik a fönévi rész is. Annál is inkább lehetséges ez, mert a mondat e fönévi rész nélkül is teljes értékü lehet azáltal, hogy a melléknév alkalmi fönévként az alany, tárgy, határozó szerepét is betöltheti” (Károly 1958: 43).

Károly külön alfejezetet szentel az -é birtokviszonyjellel ellátott értelmezőnek, amely az értelmezett szó birtokos jelzőjének feleltethető meg.

Az -é jel másik funkciója, amikor egy olyan értelmezőn jelenik meg, amely egy másik -é jeles értelmezőhöz járul, ilyenkor a két értelmező azonosító viszonyban áll egymással, és a második értelmező csak az értelmezős szerkezetre jellemző egyeztetés miatt viseli az -é jelet (45a). A (45b) példa Károly (1958: 43)-ban található.

a. elsösorban lelkiüdvünkkel volt baj, föleg a mienkével, gyermekekével

[Illyés 55]

b. Sok kabát lógott a fogason. Könnyen felismertem Pistiét, a sógoromét.

c. itt az egész rokonság az övé, a feleségéé

[Ady 305]

A második helyen megjelenő -é jeles szót azért sem tekinthetjük birtokost kifejező értelmezőnek, mert sok esetben az első -é jeles szó sem tartható értelmezőnek. Az egyik ilyen eset, amikor a birtokszó, amelyre visszautal az -é jeles birtokos, egy előző mondatban jelenik meg (45b). Abban az esetben sem tekinthető az -é jeles szó birtokos értelmezőnek, ha olyan értelmezett szóval áll kapcsolatban, amely állítmány szerepét tölti be a mondatban (45c).

Ha a nem -é jeles értelmezett szónak van egy birtokos jelzője, akkor az -é jeles értelmező Károly (1958: 44) szerint többnyire kétfelé viszonyul: egyrészt az értelmezett szóhoz mint birtokost kifejező értelmező (ezt a viszonyt jeleníti meg az -é jel), másrészt az értelmezett szó birtokosához mint azonosító értelmező (46). 
(46) a. egy derék férj arca, Sátordy bíró úré

[Babits 40]

b. Az Iczik zsidóné fia, azé a szegény özvegyasszonyé, aki a templom mellett lakik

[Mikszáth: Noszty II. 77]

c. A feltörö polgárság... dacos gesztussal vitte be a költészetbe a maga világának képeit és szavait: a paraszti, az ipari és a nagyvárosi életét

[Csillag 1952: 612]

„Az értelmezett szót megelőző birtokos jelző és a birtokost jelentő értelmező nincs mindig szükségképpen értelmezős viszonyban. Ilyenkor az -é jeles értelmező csak birtokviszonyt fejez ki, azonosítás nélkül” (Károly 1958: 44).

(47) a régi időkben a magyar történelem... a nagybirtokosok, illetve nagybirtok története, a föurak veszekvéseié

[Illyés 74]

A sajátos azonosító értelmezők közé Károly azokat a szerkezeteket sorolja, amelyeknek tagjai igék (igenevek), vagy melléknevek (számnevek), vagy határozószók, illetve ragos vagy névutós főnevek, névszók. Ez utóbbit, az azonosító határozói értelmezőt tartja a leggyakoribbnak. Az azonosító határozói értelmezők csoportján belül példákat hoz a helyhatározói (48), az időhatározói (49), az állapothatározói (50) és egyéb határozói értelmezőre (51). A (49c) Károly (1958: 46) saját példája.

(48) a. egy gyalogezredet is ide helyeztek, az egészséges városba

[Mikszáth: Noszty I. 3]

b. Künn a mezökön

[Ady: Hét évsz. 734]

c. itt, a záporverte mezőn

[Ady: Hét évsz. 720]

d. A szobában lakik itt benn

[Petőfi: Anyám tyúkja]

e. mindenki valahova máshova néz

[Szabó 164]

f. Haza, azaz szállásomra

[Ady 506]

g. Lett volna csak itt Béla is, ahol ö volt... vagyishogy... Pesten, az orvosnál

[Szabó: Most II. 216]

(49) a. a következö pillanatban - azaz holnap

[Babits 68]

b. Akkor... bátyám sziuletése után

[Illyés 47]

c. másnap, vasárnap

(50) a. a három fiú együtt s egyedül, azaz hármasban és fölügyelet nélkül van

[Ady 134] 
b. Nelli az alázat pozitúrájában volt, azaz térdenállva

[Babits 493]

c. vagy krumpli mezétláb, azaz hús nélkül

[Illyés 159]

(51) a. Így telt el a délelött, ilyen kedves csevegésben.

[Móricz 155]

b. elfoglalta azt, ezúttal komolyan, azaz magának

[Illyés 71]

Károly a sajátos azonosító értelmezők közé sorolja azokat a szerkezeteket is, amelyekben melléknévi (52a-c) vagy számnévi (52d, e) tagok között történik az azonosítás. Ezt ritka típusnak tartja. Az (52c, d) példák származási helye Károly (1958: 46).

(52) a. Ezeket a területeket... István egyszerre királyi, azaz saját birtokának jelentette ki.

[Illyés 71]

b. Urasági, vagy grófi, azaz közös, amelyböl mindenki nyalából

[Illyés 33]

c. kétszer három, azaz hat

d. sok, azaz tízezer

Szintén ritka típusnak nevezi, amikor igei (igenévi) tagok között történik azonosítás (53). Az (53c) adat Károly (1958: 46)-ban található.

a. egészen furcsa... játékot eszeltünk ki és folytattunk - azaz továbbéltük minden alkalommal [Kaffka 17]

b. rágyújtanak, mókáznak, ejtözködnek: pihennek

[Veres 10]

c. szeretnék segíteni rajtad, azaz a helyzeteden könnyíteni

\subsubsection{Leíró nyelvtanok}

Az alábbiakban összefoglalom mindazt, amit a magyar leíró nyelvtanok (Tompa [szerk.] 1962, Rácz [szerk.] 1968, A. Jászó [szerk.] 1991, Keszler [szerk.] 2000, Keszler-Lengyel 2002) az értelmezővel kapcsolatban állítanak.

„Az értelmezős szerkesztésmód feltehetően (...) ősi alapnyelvi eredetü” (Benkő [szerk.] 1967: 453), első fennmaradt szövegemlékeinkben már van rá példa (54).

(54) a. terumteve... miv ifemucut adamut

[Halotti beszéd]

b. fyodumtul ezes urume(m)tuul

[Ómagyar Mária-siralom] 


\subsubsection{Az értelmező tulajdonságai}

A magyar nyelvü leíró nyelvtanok (Tompa [szerk.] 1962, Rácz [szerk.] 1968, A. Jászó [szerk.] 1991, Keszler [szerk.] 2000, Keszler-Lengyel 2002) nem adnak egy pontos definíciót az értelmezőre, hanem a fogalmának tárgyalása során az alábbi tulajdonságokat emelik ki (amelyeket a 2. fejezetben fogok pontosítani, módosítani, illetve kiegészíteni):

a) Az értelmező mindig az alaptagja, vagyis az értelmezett szó után áll (55).

(55) Jönnek a sportolók, a győztesek.

b) Az értelmezett szóval szám, viszonyrag, névutó, birtokjel tekintetében megegyezik az értelmező, vagyis közöttük számbeli és esetbeli egyeztetés van (56).
a. Ott van a testvérem $-\emptyset$, a legfiatalabb $-\emptyset$.
b. Kiállították a festményem-et, a legszebb-et.
c. Lemondtam a csizmá-ról, a piros-ról.
d. Ez a könyv a fiam-é, a kisebbik-é.

c) Az értelmező rendszerint szünettel különül el a jelzett szótól, a szerkezetnek két hangsúlya van.

d) Az értelmező utólag értelmezi a jelzett szóban megjelölt dolgot minőségi, mennyiségi jegyének, birtokosának vagy a vele azonosított dolognak a megnevezésével. Ennek alapján az értelmezőt a nyelvtani hagyomány a jelzők közé sorolja be. Emellett szól az értelmezős szerkezet azon tulajdonsága is, hogy átalakítható alany-állítmányi szerkezetté.
a. a piros csizma $\rightarrow$ a csizma piros
b. a csizma, a piros $\rightarrow$ a csizma piros

e) Az értelmező mindig szabad bővítmény.

\subsubsection{Az értelmezó fajtái}

Az alábbiakban röviden ismertetem az értelmező fajtáit a leíró nyelvtanok csoportosítása alapján. 
a) A hátravetett jelzői értelmező átalakítható elöl álló jelzővé. A minőség- és mennyiségjelzővel, valamint a nem névmási kijelölö jelzővel párhuzamba állítható értelmező minőségi, illetve mennyiségi tekintetben (58a-c), míg a birtokos jelzőnek megfelelő értelmező a birtokos utólagos megjelenítésével értelmezi a jelzett szót (59). Az (58a-c)-ben látható példákat minösítö értelmezőnek is nevezik. A mutató névmási kijelölő jelző is állhat a jelzett szava mögött, de ebben az esetben inkább már az azonosító értelmezőhöz áll közelebb (60).

(58) a. Vettem almát, zöldet.

b. Egyél narancsot, sokat!

c. A tanáromat, az elsốt nem felejtem el.

(59) Visszahoztam a könyvet, Péterét.

(60) Visszahoztam a könyvet, azt, amelyik Péteré volt.

b) Az azonositó értelmező olyan hátravetett jelző, amely nem alakítható át elöl álló jelzővé (61). Az értelmezős szerkezet tagjai közti viszony az azonosítás. ${ }^{8}$

Mari, a barátnőm tegnap meglátogatott.

c) Bár a leíró nyelvtanok nem tárgyalják az értelmező fajtái között az értelmezői határozót, de megemlítik annak példájaként, hogy a viszonyító eszközök különbözősége is megfigyelhető ezekben az esetekben (62). Ilyenkor két határozó egymással értelmezőszerű kapcsolatba kerül, vagyis a második szükíti, pontosítja az első határozó jelentését (62a), vagy esetleg azonosítja $(62 b, c)$.
a. Bécsbe, a föpostára
b. fent, a dombon
c. lent, a völgyben

Az értelmezői határozók abban különböznek a másik két csoporttól, hogy nem alakíthatók át predikatív viszonnyá: a (62a) példában ennek akadálya az, hogy a tagok nem az azonosítás

\footnotetext{
${ }^{8}$ Pontosabban kifejezve a tagok közti viszony alatt a referenciális azonosítást értjük.
} 
viszonyában állnak egymással, míg (62b, c)-ben morfológiai korlátok ${ }^{9}$ vannak, ugyanis az egyik tag határozószó.

\subsubsection{Az egyez(tet)és}

A magyar nyelvben a melléknév + főnév szórend esetében nincs egyeztetés, a melléknév mondatrészi szerepét kijelöli a kötött szórend és rendszerint a hangsúly is. Ezzel szemben az értelmezői szerepű melléknév a fordított szórend és az önálló hangsúly miatt indokolttá teszi a szám- és esetbeli egyez(tet)ést ${ }^{10}$, amely meghatározza az értelmezett szó és az értelmező viszonyát.
a. Láttam a fiúkat, a győzteseket.
b. A lányom egy csizmáról, egy pirosról álmodik.

\subsubsection{A szerkezet elemzése}

A következőkben a magyar szakirodalomban fellelhető érveket ismertetem, amelyek az értelmezős szerkezet alárendelésként (Károly 1958, Tompa 1964, Rácz 1991), mellérendelésként (Szabó 1955; Antal 1964, 1977; Jakab 1977, 1978) vagy átmeneti szerkezetként (Balogh 1999) való elemzése mellett szólnak. Dér (2001) az alárendelő és a mellérendelő viszonyt elvetve amellett érvel, hogy szószerkezeti szinten egy harmadik viszony is létezik: az azonosító/értelmezői viszony.

\subsection{Az alárendelés melletti érvek}

A szerkezetet alárendelésként elemzők egyik érve, hogy a hátravetett jelzői értelmezős szerkezet átalakítható jelző + jelzett szó szerkezetté.

$$
\text { az almát, a zöldet } \rightarrow \text { a zöld almát }
$$

A következő érvük az, hogy az értelmezős szerkezet tagjai között - szemben a mellérendeléssel - predikatív viszony hozható létre.

\footnotetext{
${ }^{9}$ Szintaktikai korláttal is számolnunk kell: a határozószó nem töltheti be alany vagy predikátum szerepét a mondatban.

${ }^{10}$ A hagyományos nyelvtanok következetesen az egyeztetést használják annak a jelenségnek a leírására, hogy az értelmező és az értelmezett száma, esete megegyezik. Mivel az egyeztetés csak alárendelt tagok között lehetséges, az egyezés terminust fogom használni, hogy az olvasó ne jusson arra a téves következtetésre, hogy az értelmezett és az értelmező közti alárendelő viszony mellett érvelek.
} 

a. a könyv, azérdekes $\rightarrow$ a könyv érdekes
b. a könyv és a film $\rightarrow *$ *a könyv (a) film

Rácz (1991) úgy érvel az alárendelés mellett, hogy cáfolja a mellérendelés mellett szóló érveket. Szerinte a mellérendelésben az esetragok megegyezése nem az egyeztetés következménye, hanem azé, hogy a szerkezettagok azonos módon függnek a fölérendeltjüktől. Ráadásul „az esetbeli egyeztetésnek együtt kell járnia a számbeli egyeztetéssel” (uo.: 16), márpedig a mellérendelő szintagmában nem kötelező a számbeli egyeztetés (66a). Ezzel szemben az értelmezős konstrukcióban az esetbeli egyeztetés együtt jár a számbeli egyeztetéssel (66b). Továbbá az értelmezős szerkezet tagjai koreferenciálisak (66b), míg a mellérendelő szerkezet tagjai nem azok (66a), a kifejtő magyarázó mellérendelés kivételével, amely igen közel áll az azonosító értelmezős szerkezethez (66c).
a. Meghívták a fiamat és a lányokat.
b. Meghívták a lányokat, a legszebbeket.
c. Meghívták Máriát, vagyis a barátnömet.

\subsection{A mellérendelés melletti érvek}

A mellérendelés melletti érvként hozható fel az értelmezős szerkezet tagjai közti egyeztetés a számbeli viszonyokat és az esetragokat tekintve, amelyhez hasonlóan megfigyelhető az esetragok egyezése a mellérendelő szószerkezeteknél is. Amint azonban az előző pontban láttuk, ezt az érvet Rácz (1991) cáfolja.

Az azonosító értelmezős szerkezet tagjai felcserélhetők egymással, akárcsak a legtöbb mellérendelő szerkezet tagjai.

Bármelyik tag elhagyható a szerkezetből, s többnyire egyik taggal sem tudunk a másikra rákérdezni.

Az értelmezős szerkezet tagjai közé kitehetők a kifejtő magyarázó mellérendelés kötőszavai (azaz, vagyis).

Az alárendelő szerkezet ellen szól, hogy csak a hátravetett jelzői értelmező alakítható át jelzős szerkezetté, az azonosító értelmező és a határozói értelmező nem, így ez az ellenérv a mellérendelés melletti érvnek tekinthető. 


\subsection{Az értelmező mint sajátos átmeneti szerkezet}

Az értelmezős szerkezet átmeneti volta abból adódik, hogy több fajtája is van, értelmező és értelmezett viszonyba nemcsak a jelző és a jelzett szó kerülhet, hanem más mondatrészek is.

Balogh (1999) amellett érvel, hogy az értelmezős szerkezet sajátos átmenetet képez az alárendelö és a mellérendelő szintagmák között. Tagjai funkcionálisan azonos értéküként viselkednek a mondatszerkezetben, fölérendeltjükhöz azonos grammatikai viszony füzi őket, erre utal viszonyító eszközeik azonossága vagy funkcionális hasonlósága. Ennek következtében akár meg is kérdőjelezhetnénk a tagok között látható azonos esetvégződés egyeztetésből adódó voltát. A számbeli egyezés azonban mégiscsak arra utal, hogy egyeztetés történik az értelmezett szó és az értelmező között.

A kifejtő magyarázó mellérendeléshez hasonlóan itt is azonos az értelmezett szónak és az értelmezőnek a denotátuma.

Ezen érvek alapján tartja Balogh az értelmezős konstrukciót átmeneti szerkezetnek az alá- és mellérendelés között.

\subsection{Az azonosító / értelmezői viszony}

Dér (2001) kétféle értelmezőt különböztet meg: az azonosító és a „közönséges” értelmezőt (az utóbbi a hagyományos nyelvtanokban a minőség-, mennyiség- és birtokos jelzői értelmezőnek felel meg). Csupán látszatnak tartja a közönséges értelmezői típusok és a minőség-, mennyiség-, birtokos jelzők egymásnak való megfeleltethetőségét, ahogyan az értelmezett szó és az értelmező közötti egyeztetést is. Szerinte ,az értelmező tag egy teljes jelzős szerkezetet képvisel, így nem lehet jelzője az értelmezettnek” (uo.: 80), vagyis nem beszélhetünk alárendelésről. A mellérendelő viszony lehetőségét arra hivatkozva veti el, hogy az értelmezett szó és az értelmező denotátuma azonos, míg a mellérendelő szerkezet tagjaié rendszerint nem. Az értelmező mindkét típusánál egy „,új” grammatikai viszonyt feltételez, amelyet azonosításnak nevez. A „közönséges” értelmező esetében redukció történik, vagyis hogy elkerüljük a szó szerinti ismétlést, az értelmezett szó után egy elliptikus jelzős szerkezet jelenik meg. Dér egy fontos különbséget emel ki a kétféle értelmező között: míg az azonosító értelmező esetében egyértelmüen megmutatható az azonosítás grammatikai viszonya, addig a „közönséges” értelmező esetében az azonosítást csak ,,a redukció folytán kimaradt alaptag visszateljesítése révén ismerhetjük fel” (uo.: 82). 


\subsubsection{Balogh Judit $(1999,2003,2004)$}

Balogh (1999) az értelmezőt már nem a jelzők altípusaként tárgyalja, noha szintén használja a hátravetett jelzői terminust, de a szerkezet másik két fajtája, az azonosító értelmező és az értelmező határozó kapcsán megemlíti, hogy azok nem mutatnak rokonságot a jelzős szókapcsolatokkal.

Az értelmezős szerkezet helyét vizsgálva a szintagmák között Balogh (2003) összehasonlítja az értelmezőt a jelzőkkel. A minősítő jelzőknek (a minőség- és a mennyiségjelző sorolható ide) nincs viszonyragjuk, így a szerkezeten belül a szórendi kötöttség jelöli a nyelvtani viszonyt. A jelzők közül egyedül a mutató névmási kijelölő jelző viseli magán a jelzett szó inflexiós toldalékait, többesjelét, esetragját és névutóját. Ez az oka annak, hogy Balogh (2003) párhuzamot von az ez/az mutató névmási kijelölő jelző és az értelmezős szerkezet között. Vegyük sorra az általa összegyüjtött hasonlóságokat és különbségeket. A (67-72)-es adatok Ba$\operatorname{logh}$ (2003: 462-463)-ban találhatók. ${ }^{11}$

1. táblázat: A névmási kijelölö jelzö és az értelmezős szerkezet összehasonlítása

\begin{tabular}{|l|l|l|}
\hline Szempont & \multicolumn{1}{|c|}{ Névmási kijelölö jelző } & \multicolumn{1}{c|}{ Értelmezős szerkezet } \\
\hline sorrend & $\begin{array}{l}\text { Mindig a jelzett szó elött áll, csak } \\
\text { azzal együtt mozoghat a mondatban. }\end{array}$ & $\begin{array}{l}\text { Az értelmező az értelmezett szó után } \\
\text { ál, a helyét szabadon, az értelme- } \\
\text { zett szótól függetlenül is megváltoz- } \\
\text { tathatja. }\end{array}$ \\
\hline hangsúly & A szerkezetnek egy hangsúlya van. & A szerkezet két hangsúlyú. \\
\hline natározott & $\begin{array}{l}\text { A jelző és a jelzett szó között mindig } \\
\text { megjelenik a határozott névelö. }\end{array}$ & $\begin{array}{l}\text { Az értelmező elött gyakran, de nem } \\
\text { mindig található határozott névelö. }\end{array}$ \\
\hline
\end{tabular}

\footnotetext{
${ }^{11}$ A (69)-es példákkal kapcsolatban pontosítani kell Balogh (2003: 464) azon megállapítását, hogy ,az értelmező és az értelmezett szó ragjai gyakran, de nem mindig azonosak", ugyanis az idézett adatokban az azonos alakú esetragok hiánya nem az értelmezős szerkezet tulajdonságából fakad. (69a)-ban az értelmezett szó - az értelmezőhöz hasonlóan - tárgyesetben van, a tárgyrag hiánya az értelmezetten megjelenő birtokos személyjelnek köszönhetö. (69b)-ben a locativusi - $t$ rendhagyó, csak kivételes esetekben jelenik meg, (69c)-ben pedig az esetragok megegyezésének hiánya azzal magyarázható, hogy az értelmezett egy határozószó. Mindehhez hozzátenném, hogy a helyviszonyok megadásánál lehetséges eltérő esetragok megjelenése, ha ugyanazt az irányt fejezik ki (például a fövárosban, Budapesten esetében két lokatívuszi kifejezés áll egymással értelmezői viszonyban).
} 


\begin{tabular}{|c|c|c|}
\hline egyez(tet)és & $\begin{array}{l}\text { A jelző és a jelzett szó között a bir- } \\
\text { tokjel, a többes szám jele és az eset- } \\
\text { ragok tekintetében megvalósul az } \\
\text { egyeztetés (67). Azonban sosem kap- } \\
\text { ja meg a mutató névmás a birtokos } \\
\text { személyjelet, az -ék többesjelet, az -i } \\
\text { birtoktöbbesítő jelet (68). }\end{array}$ & $\begin{array}{l}\text { Az értelmező és az értelmezett szó } \\
\text { toldalékai többnyire megegyeznek. A } \\
\text { ragok gyakran, de nem mindig azo- } \\
\text { nosak (69). Az értelmező felveheti az } \\
\text { értelmezett jeleit, de azok teljes } \\
\text { egyezése nem kötelező a két szerke- } \\
\text { zettagon (70). }\end{array}$ \\
\hline névutó & $\begin{array}{l}\text { A szerkezet mindkét tagja után meg- } \\
\text { jelenik a névutó (71a). Rag és névutó } \\
\text { nem válthatja egymást ebben a szer- } \\
\text { kezetben. }\end{array}$ & $\begin{array}{l}\text { A névutónak nem kötelező megjelen- } \\
\text { nie az értelmezett szó után is, állhat } \\
\text { csak az értelmező után ( } 71 b) \text {. Rag és } \\
\text { névutó válthatja egymást az értelme- } \\
\text { zős szerkezeten belül (71c). }\end{array}$ \\
\hline $\begin{array}{l}\text { mellérendelő } \\
\text { szintagma }\end{array}$ & $\begin{array}{l}\text { A többségi jelentés nem adható meg } \\
\text { mellérendelő szintagma által ( } 72 \mathrm{a} \text {, } \\
\text { b). }\end{array}$ & $\begin{array}{l}\text { A többségi jelentés mellérendelö } \\
\text { szintagma által is megjelenhet }(72 \mathrm{c} \text {, } \\
\text { d). }\end{array}$ \\
\hline
\end{tabular}

(67) a. azé a lányé

b. ezek a fiúk

c. arról a vitáról

(68) a. arról a feladatomról

b. ezek a Balázsék

c. azok a hallgatóim

d. azoké a tornászlányokéi

(69) a. Kérem a cipőm, az újat!

b. Pécsett, ebben a szép városban azelött nem jártam.

c. Ausztriában fent, a hegyekben még ilyenkor is nagy a hó.

(70) a. Éváék, a barátnőmék

b. a nadrágját, a feketét

(71) a. A helyett a lány helyett Anita tartotta meg az elöadást.

b. Ágnes, a barátnöm helyett ma Tamás válaszol a kérdésekre.

c. Valaki elvitte lentröl, a ház elól a kiselejtezett bútorokat.

(72) a. *Ez és az a könyvek a te szobádban voltak.

b. *Azok a muskátli és a petúnia az alsó erkélyre valók.

c. Ez és az, (vagyis) a könyvek, a te szobádban voltak. 
d. A muskátli és a petúnia, azok, az alsó erkélyre valók.

Balogh (2003: 464-465) néhány példával cáfolja azt az általános vélekedést, hogy a hátravetett jelzői értelmező visszahelyezhető az eredeti jelzői szerepbe (73).

a. Verset, kettöt is megtanultunk tegnap délután. $\rightarrow$ ? Kettö verset is megtanultunk tegnap délután.

b. Ő, az ügyes mindent el tud készíteni. $\rightarrow * A z$ ügyes ő mindent el tud készíteni.

c. A dolgozat, a tiéd jobban sikerült. $\rightarrow * A$ tiéd dolgozat jobban sikerült.

d. A kutya, a szomszédé elveszett. $\rightarrow *$ A szomszédé kutya elveszett.

Ezek a példák azonban nem alkalmasak annak illusztrálására, hogy a hátravetett jelzői értelmező nem mindig helyezhető vissza az elöl álló jelzői pozícióba. (73a)-ban az elöl álló jelzőt tartalmazó mondat is jól formált, a két szerkezet különbsége az értelmező sajátos szerepéből adódik, és más példáknál is kimutatható (Zöld almát vettem. $\rightarrow$ Almát, zöldet vettem.) (73b)ben a személyes névmás megjelenése miatt kizárólag azonosító értelmezőről beszélhetünk, a névmási értelmezett szót tartalmazó szerkezeteket már Károly (1958) is az azonosító értelmezők közé sorolta (1. a (27b-d) adatokat). (73c, d)-ben pedig az értelmező elöl álló jelzővé alakításakor hasonlóan kell eljárnunk, mint azokban a példákban, ahol az értelmező jelet visel (74).

(74) a. A sportolók, a gyöztesek büszkén vonultak végig a pályán. $\rightarrow$ A gyöztes sportolók büszkén vonultak végig a pályán.

b. A dolgozat, a tiéd jobban sikerült. $\rightarrow$ A te dolgozatod jobban sikerült.

c. A kutya, a szomszédé elveszett. $\rightarrow$ A szomszéd kutyája elveszett.

A (74)-es példákban az értelmező elöl álló jelzővé alakítása során elveszíti a rajta lévő ragot és jeleket, azonban a birtokos viszonyt jelölni kell, ezért (74b, c)-ben a visszahelyezés során kötelezően megjelenik a jelzett szón a birtokos személyjel, illetve a birtokoltságjel.

Az azonosító értelmező kapcsán Balogh (2003) megjegyzi, hogy az sosem volt jelzős szerkezet, így fel sem merül annak kérdése, hogy átalakítható-e elöl álló jelzővé. Az értelmező határozó esetében pedig szóba sem jön annak lehetősége, hogy jelzőnek tartsuk a szerkezetet. Mindezek alapján Balogh amellett érvel, hogy az értelmezőt nem sorolhatjuk a jelzők közé. Okfejtése a következő: Az értelmezö „lazán, utólag, mintegy külön állításként értelmezi a 
korábbi, eredeti jelzett szót, az alaptagot, vagyis az értelmezett főnevet. Legtöbbször külön hangsúlyt is kap, szünettel is elkülönül tőle" (Balogh 2003: 465). További fontos eltérés a jelző és az értelmező között, hogy az utóbbin inflexiós toldalékok, jelek és ragok jelennek meg, míg a jelzőn nem. Ezeknek a toldalékoknak köszönhetően az értelmező távolra is kerülhet az értelmezett szótól (A gitárosokat is meghívták az esti elöadásra, a legjobbakat.). Tehát a jelzőre jellemző szórendi kötöttség és morfológiai jelöletlenség nem érvényesül az értelmezős konstrukcióban. Továbbá Balogh amellett érvel, hogy a névmási kijelölő jelzőtől eltérően az értelmezős szerkezetben nem egyeztetés történik, hanem a melléknév alkalmilag főnevesül, és az értelmező ugyanolyan mondatrész szerepét tölti be, mint az értelmezettje, és ennek köszönhető, hogy ugyanazt a nyelvtani viszonyt megjelenítve az értelmező az értelmezett szóval megegyező esetragot vesz fel.

Balogh (2003) szerint a minősítő és a tulajdonító értelmező esetében a jelzős szerkezet redukciója érvényesül (Jakab 1977 nyomán): a hoztam pogácsát, finomat valójában a hoztam pogácsát, finom pogácsát azonosító szerkezet rövidült alakja.

a. Korábbi elemzés

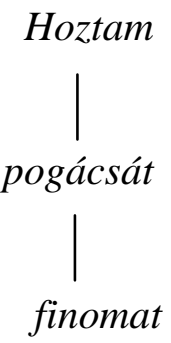

b. Balogh elemzése

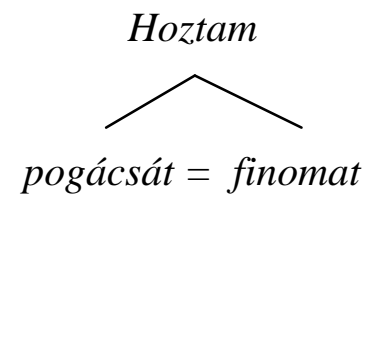

Miután Balogh (2003) kizárta az értelmezőket a jelzők, sőt az alárendelő szerkezetek köréből (1. (75b) elemzést), Balogh (2004) továbbra is az értelmező helyét vizsgálva a szintagmák között bevezet egy új szintagma-típust az alárendelő és a mellérendelő szókapcsolatok mellett: az értelmező-azonosító szintagmát. Ezt a következőképpen határozza meg: „,az azonos mondatrészi szerepet betöltő szerkezettagok közül a második tag értelmezi, más fogalmi kategóriával - kiegészítő tulajdonsággal, helyesbítő, pontosító vagy azonosító jelleggel, esetleg a részletesség kifejezésével - jellemzi az értelmezettet” (uo: 75). Az értelmező-azonosító szintagma fajtái a következők (Balogh 2004: 76):

1. A minősítő értelmezős szerkezet, melynek tagjai között szerepelhet a mégpedig kötőszó (76a).

2. A tulajdonító értelmezős szerkezetben is megjelenhet a mégpedig kötőszó (76b). 
3. Az azonosító értelmezős szerkezetben az azaz, vagyis kötőszó előfordulása figyelhető meg.
a) fônévi azonosítás (76c)
b) „sajátos azonosítás” (76d-f)

4. A pontosító-helyesbítő értelmezős szerkezet a vagyis, illetve kötőszóval állhat (76g).

5. Az egész-rész viszonyt mutató, részleges értelmezős szerkezet:

a) a szerkezet tagjai között nincs teljes azonossági viszony (76h).

b) az értelmezett szó jelentéstartalmának csak egy részét kifejező, köztük, benne névmással kapcsolt típus (76i).

c) a kiemelő értelmező a föleg, elsösorban, különösen, mindenekelött kapcsolóelemmel együtt jelenik meg (76j).

d) a példaadó értelmező a például, mint kötőelemmel jár együtt (76k).

6. A mint-es értelmező (761).

(76) a. Szeretem a rétest, az, almásat.

b. Hozd be a gitárt, Gergöét!

c. Találkoztam Virággal, a tanítványommal.

d. Fenn, a dombon mindig van hó.

e. Holnap tanulnom, azaz olvasnom kell.

f. Egész nap csak énekeltek, táncoltak, vagyis mulattak.

g. Fehér, vagyis krémszínü függönyt vettünk.

h. Az ELTE BTK magyar tanszékei Budapesten, (mégpedig) az Astoriánál vannak.

i. az ELTE szakemberei, köztük a bölcsészet képviselöi

j. a megye területein, fóleg a városokban

k. egyes kerületekben, mint a II. kerületben

1. bátyámat mint tanút hívták be

\subsection{Nemzetközi szakirodalom}

A következőkben a nemzetközi szakirodalom ismertetése következik a legújabb megközelítésekre, eredményekre helyezve a nagyobb hangsúlyt, és csak felvillantva az elözményeket. A terjedelmi korlátok miatt a korábbi munkákra csak hivatkozom, illetve a legfontosabb gondolatokat emelem ki belölük. Fontos újra hangsúlyozni, hogy a nemzetközi nyelvészeti mun- 
kákban az appozíció (apposition) alatt egy olyan fogalmat értenek, amely a magyar szakirodalomban az azonosító értelmező terminusának feleltethető meg.

\subsubsection{Az appozíció fogalma}

Sopher (1971) szerint az appozíciós szerkezet két elemének szintaktikailag és szemantikailag is ekvivalensnek kell lennie. Szintaktikailag a szerkezettagok egyetlen összetevőt alkotnak, szemantikailag pedig egyetlen referensük van, és ekvivalensnek kell lenniük.

Ahhoz, hogy ez a definíció alkalmazható legyen az értelmezőre, pontosan meg kell határozni, hogy mit is értünk az ekvivalencia fogalma alatt.

Quirk et al (1985) alapján az ekvivalencia fogalmát, kritériumait az appozíciós szerkezetre vonatkozóan a következőképpen adhatjuk meg:

1. A nominális appozíciós szerkezet tagjainak referenciálisan azonosnak kell lenniük, vagy az egyik referenciájának benne kell lennie a másikéban.

2. Bármelyik szerkezettagnak elhagyhatónak kell lennie anélkül, hogy az hatással lenne a mondat grammatikusságára.

3. Mindkét szerkezettag ugyanazt a szintaktikai funkciót tölti be a mondatban.

4. Nincs különbség az eredeti szerkezet és az egyik szerkezettag elhagyásával létrejövő mondat között az extralingvisztikai referenciát tekintve.

Ezek a feltételek azonban nem teljesülnek minden esetben. A szoros értelmező (close apposition) esetében nem hagyhatóak el a szerkezet tagjai, hiszen azok együttesen határozzák meg a DP referenciáját (1. a következő pontot).

Hannay-Keizer (2005) szerint a koreferencialitás kritériuma azért problémás, mert nem minden értelmező referenciális. Ha az értelmező egy puszta főnév, akkor annak nincs referenciája, és nem hagyható el az értelmezett, ha a puszta főnév argumentum-pozícióban jelenik meg (77).

a. But in the 1830s, Dr Thomas Arnold, Headmaster of Rugby School, saw a different side of sport.

'Azonban az 1830-as években Dr. Thomas Arnold, a Rugby School igazgatója, látta a sportnak egy másik oldalát.'

b. * But in the 1830s, Headmaster of Rugby School saw a different side of sport.

*‘Azonban az 1830-as években a Rugby School igazgatója látta a sportnak egy másik oldalát.' 
O’Connor (2008) szintén kimutatja, hogy az értelmezett szó elhagyása nem mindig eredményez grammatikus mondatot (78).

a. James, back then a little boy, impressed his audience.

'James, egy akkoriban még kicsi fiú, nagy hatással volt a hallgatóságára.'

b. *Back then a little boy impressed his audience.

*'Egy akkoriban még kicsi fiú nagy hatással volt a hallgatóságára.'

Még a 4. feltétel, az extralingvisztikai referencia is sérülhet (79). Az appozíciós szerkezet által kifejezett kapcsolat nélkül Robert és a brilliant linguist között (79b)-nek és (79c)-nek nem lesz ugyanaz a jelentése.

(79) a. Robert, a brilliant linguist, gave a talk on syntax. [angol]

'Robert, egy briliáns nyelvész előadást tartott a szintaxisról.'

b. Robert gave a talk on syntax.

'Robert elöadást tartott a szintaxisról.'

c. A brilliant linguist gave a talk on syntax.

'Egy briliáns nyelvész előadást tartott a szintaxisról.'

Crystal (1997: 24) úgy határozza meg az appozíciót, hogy a szerkezet összetevői ugyanazon a grammatikai szinten vannak, és azonos vagy hasonló referenciával bírnak.

Ez a meghatározás azonban felveti azt a kérdést, hogy mit értünk hasonló referencia alatt.

Kim (2012) azt emeli ki az appozíciós konstrukcióval kapcsolatban, hogy az a szomszédos pozícióba helyez két ekvivalens kifejezést, amelyek ugyanarra az individuumra utalnak.

\subsubsection{Az appozíció fajtái}

A nemzetközi szakirodalomban több szempont szerint is megkülönböztetnek különféle szerkezeteket az appozíción belül. Egyrészt az értelmező prozódiai, szintaktikai és szemantikai viselkedése alapján különbségek figyelhetők meg az úgynevezett szoros értelmező (close apposition) és a laza értelmező (loose apposition) között. Másrészt az értelmezett szónak és az értelmezőnek az elhelyezkedése egy specifikussági skálán három szemantikai osztály megkülönböztetését teszi lehetővé. Az alábbiakban ezeket a fajtákat ismertetem. 


\subsubsection{A szoros és a laza értelmezö}

A nemzetközi szakirodalomban (Burton-Roberts 1975, Molitor 1979, Lasersohn 1986, Acuña-Fariña 1996a, 1999; Huddleston-Pullum 2002, Keizer 2005, Potts 2005, LekakouSzendrői 2007) különbséget tesznek a szoros és a laza értelmező között. A (80)-as példák Lekakou-Szendrői (2007: 131)-ből származnak.

a. Burns the poet / the poet Burns [angol] 'Burns a költő' / 'a költő Burns'

b. Burns, the poet

'Burns, a költő'

Összehasonlítva a szoros és a laza értelmezőt, számos különbség mutatható meg a két appozíciófajta között. Az alábbiakban ezeket a különbségeket foglalom össze. A (81)-es és (85)-ös példák Lekakou-Szendröi (2007: 131, 133)-ból, a (82)-es adatok Stavrou (1995)-böl, a (83)as példamondatok Potts (2005)-böl, míg a (84)-es adatok Kolliakou (2004: 274-275)-ből, a (86-88)-as példák (Heringa 2012: 4)-ből származnak, és végül a (89)-es adatok származási helye: Lasersohn (1986: 311).

a) A szoros értelmezőben egyetlen intonációs egységet alkot a két elem (80a), míg a laza értelmezőben intonációs szünet van a két rész között.

b) A szoros értelmezőben nem ékelődhet be más elem a szerkezettagok közé (81a), míg a laza értelmezőben megjelenhet más elem is a két szerkezettag között (81b), az angolban ilyen elem például a namely, or rather, in other words.

\footnotetext{
a. *Burns namely the poet
}

*'Burns azaz a költő'

[angol]

b. the head of department, namely Prof. Todorov 'az osztályvezetö, azaz Todorov professzor'

c) A szoros értelmező két DP közötti viszonyt von maga után (82a), míg laza értelmezői viszonyban bármilyen két (azonos) kategória állhat egymással (82b).

a. *He ${ }_{V}$ ate $][v$ devoured] the whole pie.

*'Megette felfalta az egész pitét.' 
b. He [vate], or rather [V devoured] the whole pie.

'Megette, illetve felfalta az egész pitét.'

d) A szoros értelmezőben az egyetlen entitásra utaló referenciát a két DP együttesen határozza meg (83a), ezzel szemben a laza értelmezőben az első összetevő egyetlen entitást választ ki, és a második kiegészítő információt ad erről az entitásról (83b).

(83) a. Armstrong the Texan is a cyclist. Armstrong the Ohioan is an astronaut. 'A texasi Armstrong egy kerékpáros. Az ohiói Armstrong egy asztronauta.' b. Armstrong, the Texan, is a cyclist. \# Armstrong, the Ohioan, is an astronaut. 'Armstrong, a texasi egy kerékpáros. \# Armstrong, az ohiói egy asztronauta.'

e) A szoros értelmezős konstrukció korlátozó értelmű (84a), míg a laza értelmező második tagja sosem korlátozó (84a).

(84) Tonight I will speak of the Van Gogh brothers, the painter and the critic.

'Ma éjjel a Van Gogh testvérekről, a festőről és a kritikusról fogok beszélni.'

a. Van Gogh the painter...

'Van Gogh a festő...'

b. \# Van Gogh, the painter...

\# 'Van Gogh, a festő...'

f) A szoros értelmező esetében nincs az első DP-nek egyedülállósági előfeltevése (84a), míg a laza értelmezőben az első szerkezettagnak van egyedülállósági preszuppozíciója (85).

(85) Tonight I will speak of a great French artist.

'Ma éjjel egy nagyszerü francia müvészről fogok beszélni.'

a. Guillem, the dancer...

'Guillem, a táncos...'

b. \# Guillem the dancer...

\# 'Guillem a táncos...' 
g) A szoros értelmezőben mindkét rész nominális, egyik sem predikatív, míg a laza értelmezőben a második szerkezettag szemantikailag egy predikatív nominális, és nem egy referenciális nominális.

h) Az első elem nem módosítható korlátozó módon egy PP vagy egy vonatkozó tagmondat által a szoros értelmezőben (86a, b), míg a laza értelmezőben igen (86c, d).

a. *The linguist [of the year] Johnson is a brilliant man. [angol] *'Az év nyelvésze Johnson egy briliáns férfi.’

b. *The linguist [I like best] Johnson is a brilliant man. *‘A nyelvész, akit a legjobban kedvelek Johnson egy briliáns férfi.

c. The linguist of the year, Johnson, is a brilliant man.

'Az év nyelvésze, Johnson, egy briliáns férfi.'

d. The linguist I like best, Johnson, is a brilliant man.

'A nyelvész, akit a legjobban kedvelek, Johnson, egy briliáns férfi.'

i) A szoros értelmezőben a második elemet nem lehet kiterjeszteni egy attributív melléknév vagy egy determináns által (87a), míg a laza értelmezőben ez lehetséges (87b).

a. *De hoofdstad (het) beroemde Amsterdam trekt jaarlijks miljoenen a főváros a híres Amszterdam vonz évente milliók internationale bezoekers. [holland] nemzetközi látogatók

*‘A főváros a híres Amszterdam a nemzetközi látogatók millióit vonzza évente.'

b. De hoofdstad, het beroemde Amsterdam, trekt jaarlijks miljoenen a föváros a híres Amszterdam vonz évente milliók internationale bezoekers. nemzetközi látogatók

'A főváros, a híres Amszterdam a nemzetközi látogatók millióit vonzza évente.'

j) A szoros értelmezőben az értelmezett szónak határozottnak kell lennie (88a), míg a laza értelmezőben lehet határozatlan is (88b). 
(88) a. *Mary invited a linguist Johnson to her party.

*'Mary meghívott egy nyelvész Johnsont a partijára.'

b. Mary invited a linguist, Johnson, to her party.

'Mary meghívott egy nyelvészt, Johnsont, a partijára.'

k) A szoros értelmező megengedi a VP-ellipszist (89a), míg a laza értelmező nem (89b)

a. My friend Fred lives in Pittsburgh and so does my friend Dave.

'Fred barátom Pittsburgh-ben él, és Dave barátom is.'

b. * My friend, Fred, lives in Pittsburgh and so does my friend, Dave.

'A barátom, Fred, Pittsburgh-ben él, és a barátom, Dave, is.'

\subsubsection{Szemantikai osztályok Heringa (2012) alapján}

Heringa (2012) háromféle viszonyt tételez fel az értelmezett és az értelmező között: azonosítás (identification), tulajdonítás (attribution), bennfoglalás (inclusion). Az osztályozás alapja: az értelmező és az értelmezett pozíciója a specifikusság skáláján, amely a generikustól a nemspecifikuson át a specifikusig terjed. A specifikussági skálát ${ }^{12}$ az alábbi módon ábrázolja Heringa (2012: 38):

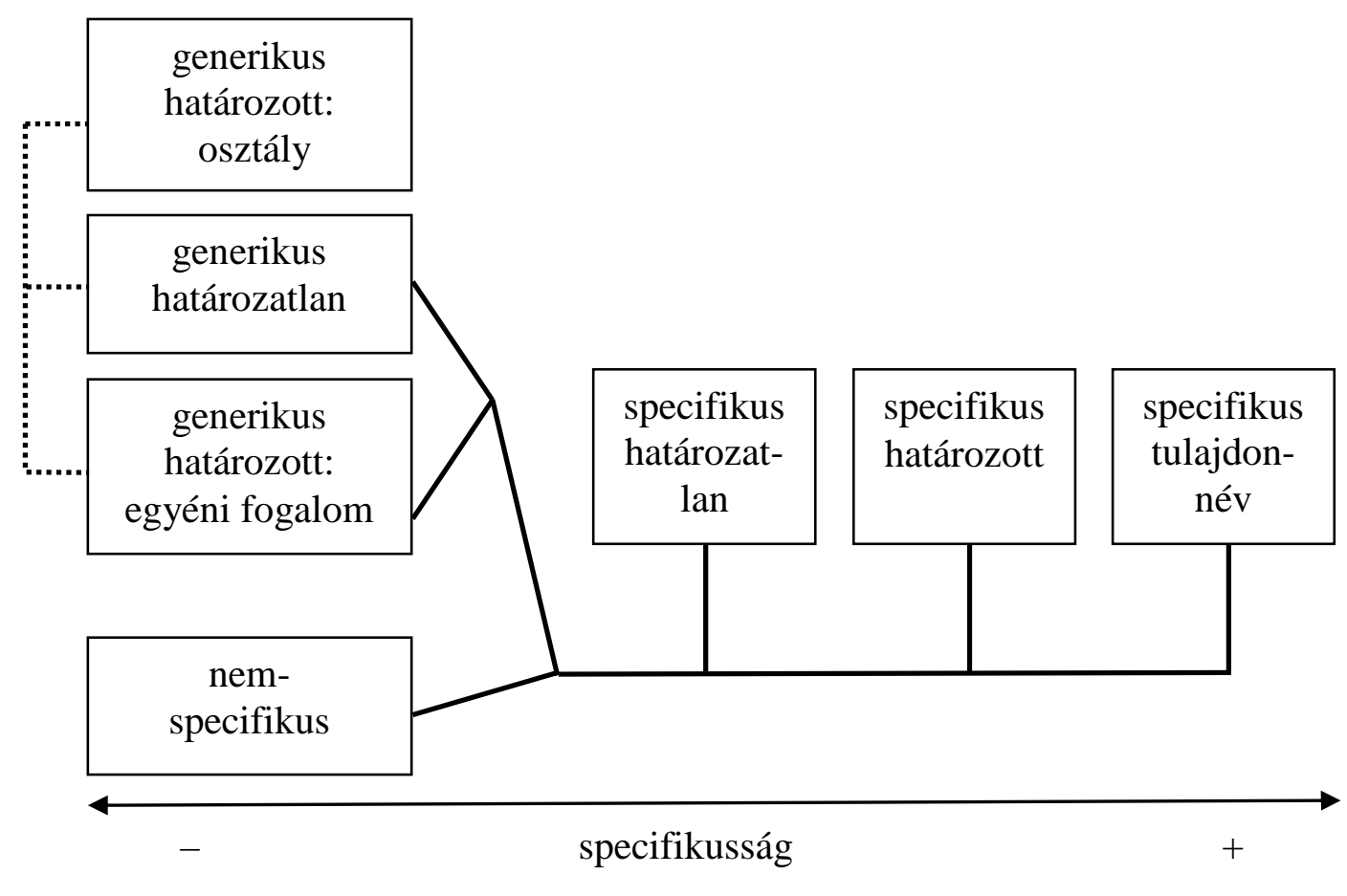

1. ábra: A specifikussági skála

\footnotetext{
${ }^{12}$ Ennek a skálának a magyar adatok esetében lesz igazán jelentősége a 3.2.2 pont alatti alfejezetben.
} 
A specifikussági skála ${ }^{13}$ rövid magyarázata: A skáláról leolvasható, hogy a legkevésbé specifikus olvasatok a nem-specifikus és a generikus interpretációk (amelyek se vertikálisan, se horizontálisan nem kapcsolódnak össze, mivel egyáltalán nem hasonlíthatók össze a specifikusságot tekintve). A vízszintesen összekapcsolt olvasatok egymáshoz viszonyított specifikussága egyértelmủen meghatározható (például a legspecifikusabb interpretáció a specifikus tulajdonnév). A szaggatott vonallal függölegesen összekapcsolt generikus olvasatok három típusa összehasonlítható egymással a specifikusságot tekintve, de nincs inherens sorrendjük.

A holland példákat az alábbi egyszerüsített táblázatokon keresztül mutatom be, amelyeket Heringa árnyaltabbá tesz a disszertációja későbbi pontján (a magyar példák ismertetésénél már a részletesebb táblázatokra fogok támaszkodni).

2. táblázat: Az azonosítás

[Heringa 2012: 26-27]

\begin{tabular}{|l|c|c|c|}
\hline Értelmezett & Generikus & Nem-specifikus & Specifikus \\
\hline Generikus & & & \\
\hline Nem-specifikus & & & \\
\hline Specifikus & & $(90 \mathrm{a})$ & (90) $)$ \\
\hline
\end{tabular}

(90)

a. De leeuw, de panthera leo, wordt met uitsterven bedreigd. [holland] az oroszlán a párduc oroszlán COP INSTR kihalás fenyegetve

'Az oroszlánt, a párducoroszlánt a kihalás veszélye fenyegeti.'

b. Jan wil graag een aapje, zo'n leuk bewonertje van de

Jan akar szívesen egy majom:DIM olyan.egy kedves lakó:DIM GEN az

Apenheul, op zijn schouder.

Apenheul SUP övé váll

'Jan szeretne a vállára egy kicsi majmot, az Apenheul-nak egy olyan kedves kis lakóját.

\footnotetext{
${ }^{13}$ Heringa (2012) megvizsgálja a specifikusság, a generikusság és a határozottság kritériumait, rámutatva, hogy egy fönévi kifejezés specifikusként vagy generikusként való interpretációja a kontextustól is függ. Kiemelve egy példát: egy határozatlan főnévi csoport specifikus (i), nem-specifikus (ii) és generikus olvasatot (iii) is kaphat a szövegkörnyezet függvényében. Az alábbi példák Heringa (2012: 35)-böl származnak.

(i) An ape climbed the tree. It was Abe.

'Egy emberszabású majom felmászott a fára. Abe volt az.'

[angol]

(ii) An ape climbed the tree. I did not know which ape it was.

'Egy emberszabású majom felmászott a fára. Nem tudtam, melyik emberszabású majom volt az.'

(iii) An ape climbs trees. That is in his nature.

'Egy emberszabású majom fákra mászik. Ez benne van a természetében.'
} 

c. De jongste bewoner van de Apenheul, dit lieve diertje, sprong a legfiatalabb lakó GEN az Apenheul ez édes állat:DIM ugrált op Jans schouder.
SUP Jan.GEN váll

‘Az Apenheul legfiatalabb lakója, ez az édes állatka Jan vállán ugrált.

3. táblázat: A tulajdonítás

[Heringa 2012: 28]

\begin{tabular}{|l|c|c|c|}
\hline Értelmezett & Generikus & Nem-specifikus & Specifikus \\
\hline Generikus & $(91 \mathrm{a})$ & & \\
\hline Nem-specifikus & $(91 \mathrm{~b})$ & & \\
\hline Specifikus & (91c) & & \\
\hline
\end{tabular}

(91) a. Jan heeft de bermzakspin, een geslacht van de spoorspinnen, ontdekt. Jan AUX a sárga.zsákpók egy nem GEN a hosszúlábú.zsákpók felfedezte 'Jan felfedezte a sárga zsákpókot, a hosszúlábú zsákpókok egy nemét.'

b. Om zijn aap te vangen heeft Janhulp van een opasser, ALL övé majom INF elkap AUX Jan segítség GEN egy gondozó

een vakman, nodig.

egy szakember szükséges

'Hogy elkapja a majmát, Jannak egy gondozó, egy szakember segítségére van szüksége.'

c. Jans huisdier, een baviaan, laat zijn tanden zien als hijboos is. Jan.GEN háziállat egy pávián engedi övé fogak lát amikor ő mérges COP 'Jan háziállata, egy pávián megmutatja a fogait, amikor éhes.'

4. táblázat: A bennfoglalás

[Heringa 2012: 29-30]

\begin{tabular}{|l|c|c|c|}
\hline Értelmezett & Generikus & Nem-specifikus & Specifikus \\
\hline Generikus & $(92 \mathrm{a})$ & & $(92 \mathrm{~b})$ \\
\hline Nem-specifikus & & $(92 \mathrm{c})$ & $(92 \mathrm{~d})$ \\
\hline Specifikus & & & $(92 \mathrm{e})$ \\
\hline
\end{tabular}


(92) a. De aap, maar vooral de orang-oetan, wordt met uitsterven bedreigd. a majom de föként az orángután COP INSTR kihalás fenyegetve 'Az emberszabású majmot, de főként az orángutánt a kihalás veszélye fenyegeti.'

b. Een aap, in het bijzonder de gorilla van Jan, is een goed klimmer. egy majom IN a különös a gorilla GEN Jan COP egy jó hegymászó 'Egy emberszabású majom, különösen Jan gorillája jó hegymászó.'

c. Jan wil een exotisch huisdier, bijvoorbeeld een aap, voor zijn verjaardag. Jan akar egy exotikus háziállat például egy majom SUB övé születésnap 'Jan akar egy egzotikus háziállatot, például egy emberszabású majmot a születésnapjára.'

d. Jan wil een huisdier, zoals de aap die hij bij de dierenwinkel Jan akar egy háziállat úgymint a majom az ő ADES a állatkereskedés zag, voor zijn verjaardag. látott SUB övé születésnap

'Jan akar a születésnapjára egy háziállatot, mint amilyen emberszabású majmot látott az állatkereskedésben.'

e. Jan kwam de groep apen die de buurt onveilig maakt, Jan jött a csoport majmok az a szomszédság veszélyes teszi waaronder de chimpnasee van Pietje, tegen. köztük a csimpánz GEN Pietj.GEN ellen

'Jan találkozott a körzetben csavargó emberszabású majmok csoportjával, köztük Pietje csimpánzaival.'

A példák alapján Heringa azt a konklúziót vonja le, hogy az értelmezős szerkezetek a következő módon csoportosíthatók:

a) Az azonosítás csoportjába tartozó szerkezetekben az értelmezett és az értelmező azonos módon specifikus.

b) A tulajdonítás esetében az értelmező generikus olvasatú, az értelmezett a specifikussági skálán bárhol lehet.

c) A bennfoglalás csoportjában az értelmező ugyanolyan specifikusságú, vagy specifikusabb, mint az értelmezett.

Heringa (2012) amellett foglal állást, hogy a holland, angol és német értelmezős szerkezetekben megjelenő ún. appozíció-jelölők (apposition markers) a három szemantikai osztály 
valamelyikében fordulhatnak csak elö, és ennek alapján már az appozíció-jelölő segítségével is lehet azonosítani, hogy az egy appozíciós példák vajon az azonosító, a tulajdonító vagy a bennfoglaló értelmezők közé tartoznak. Az 5. táblázat foglalja össze, hogy a három vizsgált nyelvben mely appozíció-jelölő mely értelmezőfajtát jelöli.

5. táblázat: Az appozíció-jelölők

[Heringa 2012: 56-58]

\begin{tabular}{|c|c|c|c|c|c|}
\hline Holland & Angol & Német & $\begin{array}{l}\text { Azono- } \\
\text { sítás }\end{array}$ & $\begin{array}{l}\text { Tulaj- } \\
\text { donítás }\end{array}$ & $\begin{array}{l}\text { Benn- } \\
\text { fogl. }\end{array}$ \\
\hline$\varnothing$ & & & $\mathrm{X}$ & $\mathrm{X}$ & \\
\hline (...) namelijk & (...) namely & nämlich & $\mathrm{X}$ & & \\
\hline te weten & to wit, viz & & $\mathrm{X}$ & & \\
\hline en wel & and & und zwar & $\mathrm{X}$ & & \\
\hline dat wil zeggen & (...) that is to say & & $\mathrm{X}$ & & \\
\hline dat is & (...) that is, i. e. & das hei $\beta \mathrm{t}$ & $\mathrm{X}$ & & \\
\hline met andere woorden & in other words & $\begin{array}{l}\text { mit anderen } \\
\text { Worten }\end{array}$ & $\mathrm{X}$ & & \\
\hline of & or & & $\mathrm{X}$ & & \\
\hline of(te)wel & & & $\mathrm{X}$ & & \\
\hline $\begin{array}{l}\text { simpel / anders } \\
\text { gezegd }\end{array}$ & $\begin{array}{l}\text { put (more) simply / } \\
\text { differently }\end{array}$ & $\begin{array}{l}\text { anders, deutlicher } \\
\text { gesagt }\end{array}$ & $\mathrm{X}$ & & \\
\hline $\begin{array}{l}\text { in technische / } \\
\text { wetenschappelijke/ } \\
\mathrm{x} \text { termen }\end{array}$ & $\begin{array}{l}\text { in (more) technical } \\
\text { / scientific / } \mathrm{x} \\
\text { terms, technically } \\
\text { (speaking) }\end{array}$ & $\begin{array}{l}\text { mehr technisch } \\
\text { ausgedrückt }\end{array}$ & $\mathrm{X}$ & & \\
\hline ook wel & & & $\mathrm{X}$ & & \\
\hline ik bedoel / ... bedoel ik & (...) I mean & ich meine & $\mathrm{X}$ & & \\
\hline ... weet je wel & ... you know & & $\mathrm{X}$ & & \\
\hline (...) zeg maar & & & $\mathrm{X}$ & & \\
\hline overigens & by the way & übrigens & & $\mathrm{X}$ & \\
\hline zoals je & as you know & & & $\mathrm{X}$ & \\
\hline Zoals bekend & & bekanntlich & & $\mathrm{X}$ & \\
\hline
\end{tabular}




\begin{tabular}{|c|c|c|c|c|}
\hline \multirow{5}{*}{$(E)^{14}$} & bijvoorbeeld & $\begin{array}{l}\text { (...) for example, } \\
\text { e.g., (...) for } \\
\text { instance }\end{array}$ & $\begin{array}{l}\text { beispielsweise, } \\
\text { zum Beispiel }\end{array}$ & $\mathrm{X}$ \\
\hline & waaronder & among them & unter anderem & $\mathrm{X}$ \\
\hline & zoals, zo ook & such as, like & so auch, wie auch & $\mathrm{X}$ \\
\hline & zeg & say & & $\mathrm{X}$ \\
\hline & $\begin{array}{l}\text { inclusief/ } \\
\text {...incluis }\end{array}$ & $\begin{array}{l}\text { including/ } \\
\text {...included }\end{array}$ & $\begin{array}{l}\text { einschlie } \beta \text { lich, } \\
\text {...eingeschlossen }\end{array}$ & $\mathrm{X}$ \\
\hline \multirow{6}{*}{$(\mathrm{P})$} & $\begin{array}{l}\text { (maar) met } \\
\text { name }\end{array}$ & notably & namentlich & $\mathrm{X}$ \\
\hline & $\begin{array}{l}\text { (maar) in het } \\
\text { bijzonder }\end{array}$ & $\begin{array}{l}\text { (but) }(\ldots) \text { in } \\
\text { particular }\end{array}$ & $\begin{array}{l}\text { besonders, } \\
\text { insbesondere }\end{array}$ & $\mathrm{X}$ \\
\hline & $\begin{array}{l}\text { (maar) } \\
\text { hoofdzakelijk }\end{array}$ & $\begin{array}{l}\text { (but) mainly / } \\
\text { chiefliy / mostly }\end{array}$ & $\begin{array}{l}\text { Hauptsächlich, in } \\
\text { der Hauptsache, in } \\
\text { erster Linie, (zu) } \\
\text { meist }\end{array}$ & $\mathrm{X}$ \\
\hline & speciaal & (but) especially & & $\mathrm{X}$ \\
\hline & $\begin{array}{l}\text { niet in het } \\
\text { minst }\end{array}$ & & & $\mathrm{X}$ \\
\hline & $\begin{array}{l}\text { (maar) vooral, } \\
\text { voornamelijk }\end{array}$ & (but) particularly & $\begin{array}{l}\text { überwiegend, vor } \\
\text { allem, } \\
\text { vornehmlich }\end{array}$ & $\mathrm{X}$ \\
\hline
\end{tabular}

\subsubsection{Az appozíciós szerkezet jellemzői}

Az appozíciós szerkezet szintaktikai és szemantikai jellemzőivel a mátrix mondathoz való kapcsolatát írhatjuk le. Az értelmezős szerkezeten belüli sorrend vizsgálata is ebben az alfejezetben kap helyet.

\footnotetext{
${ }^{14}$ A bennfoglaláson belül két csoportot lehet megkülönböztetni: szemléltetés ( $\mathrm{E}=$ exemplification) és részletezés ( $\mathrm{P}=$ particularisation).
} 


\subsubsection{A másodlagos propozíció: a tagmondati predikáció}

Az értelmező laza kapcsolatban áll a mátrix mondattal, erre utal, hogy ha az értelmezett a VP része, akkor VP-ellipszis során az értelmező nem része az ellipszis interpretációjának (Heringa 2012: 62).

a. On the left, you see an old church, a beautiful building, and on the right, you see a new one.

'Balra egy régi templomot, egy szép épületet látsz, míg jobbra egy újat látsz.'

b. (i) $=>$... and on the right a new church

'... és jobbra egy új templomot'

(ii) $\neq>$... and on the right a new church, a beautiful building

'...és jobbra egy új templomot, egy szép épületet'

A laza kapcsolatot az egyeztetés is alátámasztja: (94)-ben az alanyi pozícióban megjelenő többes számú értelmezettel, és nem az egyes számú értelmezővel egyeztetjük az igét (Heringa 2012: 62).

Land, brains, wealth and technology - in other words everyhing we need, are / *is plentiful in this country.

[angol]

'Föld, ész, vagyon és technológia, más szóval minden, amire szükségünk van, bőséges ebben az országban.'

Az értelmezett és az értelmező közti viszony interpretálható a beszélőtől származó teljes üzenetként, egy másodlagos propozícióként, elkülönítve a főmondati propozíciótól: BE (Anchor, Apposition). Az appozíciós üzenetet mindig a beszélőnek kell tulajdonítani, és nem a főmondat alanyának.

Noha a propozíciók függetlenek, és saját igazságértékük van, az appozíciós propozíció kevésbé fontos, mint a mátrix mondaté, mivel csak plusz információt nyújt.

Az appozíciós üzenet nincs nyíltan jelen, de implikálva van a konvencionális jelentésböl és a szavak kompozíciójából, ezért egy konvencionális implikatúra.

Heringa szerint ez nem pusztán szemantikai vagy pragmatikai jelenség, hanem inkább egy bonyolult szintaktikai szerkezet következménye. Az értelmezett és az értelmező közti kapcsolat egy predikatív szerkezet, amely kiterjeszthető teljes CP-vé. Heringa megmutatja, hogy az 
appozíciók nominális predikátumként viselkednek, és nem argumentumként, s ebben Doron (1994) következő érvére támaszkodik:

a) Az egyedek feletti kvantifikáció általában lehetetlen a nominális predikációban, s ugyanez igaz az appozíciókra is (95). A példák származási helye: Heringa (2012: 76).

a. *Abe, Bonnie, and Chimp are/is every chimpanzee in the zoo.

*'Abe, Bonnie és Chimp az állatkertben minden csimpánz.'

b. *We saw Abe, Bonnie, and Chimp, every chimpanzee in the zoo.

*'Láttuk Abe-t, Bonnie-t és Chimp-et, minden csimpánzt az állatkertben.’

b) Ha mégis lehetséges a kvantifikáció egy predikatív szerkezetben, akkor az azzal párhuzamos appozícióban is lehetséges Potts (2005: 131) szerint (96).

(96) a. Hillary is no amateur climber.

[angol]

'Hillary nem amatör hegymászó.'

b. We spoke with Hillary, no amateur climber, about the dangers.

'Beszélgettünk a veszélyekről Hillaryval, a nem amatőr hegymászóval.'

c) Az ún. i-wihtin-i konstrukciók nem jelenhetnek meg argumentum-pozícióban, míg predikátum-pozícióban és appozícióban igen (97), ahogyan ezt Doron (1994: 55) példája mutatja.

a. *[His s $_{i}$ own worst enemy $]_{i}$ lost the elections again.

* 'Önmaga legnagyobb ellensége újra elvesztette a választásokat.’

b. John $n_{i}$ is [his own worst enemy] . $_{\text {. }}$

'John önmaga legnagyobb ellensége.'

c. John $n_{i}$ [his own worst enemy $]_{i}$, lost the elections again.

'John, önmaga legnagyobb ellensége, újra elvesztette a választásokat.'

d) Puszta névszók is megjelenhetnek predikátumként és appozícióként, míg argumentumpozícióban nem.

e) Az appozíciók módosíthatók határozószókkal, amelyek rendszerint a predikátumot módosítják (Quirk et al 1985: 1314). 
(98) Norman Jones, then a student, wrote several best-sellers.

'Norman Jones, akkoriban tanuló, számos bestsellert írt.'

f) Az appozíciók tagadása ugyanúgy történik, mint a predikátumoké (Quirk et al 1985: 1312).

(99) Anna Wilson, not my best friend, voted against me.

'Anna Wilson, nem a legjobb barátom, ellenem szavazott.'

g) A számnevek az appozícióban (100a) és a predikátumban (100b) 'pontosan’ olvasatot kapnak, míg argumentum-pozícióban (100c) ‘legalább’ olvasatot (Doron 1994: 57).

(100) a. Mary invited her guests, two musicians from New Orleans, to have supper with her.

[angol]

'Mary meghívta vacsorára a vendégeit, két zenészt New Orleansból.'

b. Mary's guests were two.

'Mary vendégei ketten voltak.'

c. Mary invited two musicians from New Orleans to have supper with her.

'Mary meghívott két zenészt New Orleansból vacsorára.'

Ha az appozíciót egy nominális predikátumnak tekintjük, akkor elvárás lehet, hogy a szerkezetben legyen egy alany is. Az értelmezett azért nem lehet alany, mert egyidejüleg argumentumként funkcionál a mátrix mondatban. Heringa (2012) szerint az ún. komplex appozícióknak lehet nyílt alanya is (101). A (101a) példa származási helye Potts (2005: 124).

(101) a. The students, most of them linguists, missed the bus.

'A tanulók, többségük nyelvész, lekésték a buszt.'

b. Most of them are linguists.

'Többségük nyelvész.'

c. They are most of them linguists.

'Ök legtöbben nyelvészek.'

A (101a) példa egy, az értelmezettre utaló névmást is magában foglaló partitív kifejezést tartalmaz, amelyet Heringa (2012) szerint az appozíciós propozíció alanyának lehet tekinteni (101b). Ezzel szemben O’Connor (2008) amellett foglal állást, hogy az ilyen komplex appozí- 
ciókat ugyanúgy kell elemezni, mint a többi értelmezős szerkezetet, a bennük előforduló partitív kifejezést lebegő kvantornak (floating quantifier) tekintve (101c). Ezzel az elemzéssel azért nem ért egyet Heringa (2012), mert vannak olyan partitív kifejezések (few of them 'közülük kevesen', $n$ of them 'közülük n-en'), amelyek nem lehetnek lebegő kvantorok (102a), illetve megjelenhetnek az értelmezős szerkezetben olyan kvantorok, amelyek nem lebeghetnek (102b). A (101a, b) példák Heringa (2012: 83, 86)-ból származnak.

(102) a. In the last decades, there were several reforms, few of them successful changes, in the educational system.

'Az elmúlt évtizedekben volt több reform, közülük kevés sikeres változtatás, az oktatási rendszerben.

b. The old singers, some stars in their days, criticized the modern artists.

'Az idős énekesek, némelyik csillag az ö idejében, kritizálták a modern müvészeket.'

Heringa (2012) abban egyetért O’Connor (2008)-cal, hogy az egyszerü és a komplex appozíciókat ugyanúgy kell elemezni, és amellett foglal állást, hogy ha nincs nyílt alany egy értelmezős szerkezetben, akkor egy rejtett névmást kell feltételezni.

Az appozíciók szemantikai típusai korrelálnak a kopulás mondatok típusaival: A tulajdonító appozíció egy tulajdonságot rendel az értelmezett referenséhez, ahogyan a predikációs kopulás mondatban (predicational copular clause) tulajdonít egy tulajdonságot a predikátum az alany referensének. Az azonosító appozíció ad egy alternatív leírást az értelmezett által leírt entitás számára, s pontosan ez történik az azonosító kopulás mondatban (equative copular clause), ahol a kopula egyenlővé teszi az alany és a predikátum referensét.

Az appozíciónak lehet saját ideje. Ez a feltevés onnan származik, hogy az értelmezős szerkezet egyidejüséget mutathat egy referenciaponttal, ugyanakkor eltérve a főmondat referenciális idejétől (103a). Sőt az appozíciós tagmondatok időbeli határozószót is tartalmazhatnak. Az esetadás újabb bizonyíték lehet a TP jelenlétére: vannak olyan példák, amelyekben az értelmező alanyesetet kap az értelmezett esetétől függetlenül (103b). Az idő jelölése megerősíti az alany jelenlétének feltevését, amelyhez szükséges a [Spec TP]. A (103a) példa Heringa (2012: 92)-ben, míg a (103b) Bergenholtz (1985)-ben található.

(103) a. Keith, once a drug addict, now leads a rehabilitation centre.

'Keith, egykori drogfüggő, most egy rehabilitációs központot vezet.' 
b. Der Dokumentumfilm über Peter, einmal ein / *einen Junkie, zeigte die a dokumentumfilm DEL Péter egykor egy.NOM egy.ACC drogos mutatta a Veränderung in seinem Leben als er mit den Drogen aufhörte. [német] változás IN övé élet amikor ő INSTR a drogok felhagyott

'A dokumentumfilm Péterről, az egykori drogosról, megmutatta a változást az életében, amikor felhagyott a drogokkal.'

A mondathatározók jelenléte azt jelzi, hogy az appozíciós szerkezet a VP-nél magasabb funkcionális projekciókat (IP-t vagy TP-t) tartalmazhat, s Heringa amellett érvel, hogy a szerkezet valójában egy CP (104). Ezt megerősíti az alárendelő kötőszók jelenléte (105a) és a független illokúciós erő az appozíciós üzenet számára (105b). (105b)-ben a mátrix mondat illokúciós aktusa egy kérdés, míg az appozíciós üzeneté állítás. A példák származási helyei: O’ Connor (2008: 93, 97, 156); Corazza (2005: 13).

(104) a. Mr. Bartelli, often the navigator on the boat his team races, has sailed competitively since his 20 s.

[angol]

'Mr. Bartelli, gyakran a hajó navigátora a csapatversenyeken, a 20-as évei óta vitorlázik versenyszerűen.'

b. Racial profiling, unfortunately a frequent occurrence in American society, must be stopped.

'A faji jellemzést, sajnálatos módon egy gyakori jelenséget az amerikai társadalomban, meg kell állítani.'

(105) a. The road, though no longer an officially designated route, has been celebrated in books, song and a TV series.

[angol]

'Az utat, a többé már hivatalosan nem kijelölt útvonalat, könyvekben, egy dalban és egy tévésorozatban ünneplik meg.'

b. Is Jane, the best doctor in town, already married?

'Jane, a legjobb orvos a városban, már férjhez ment?'

Heringa (2012) megmutatja, hogy a bennfoglalás különbözik a másik két osztálytól, itt kötelező az appozíció-jelölő használata, a kopulás mondatokkal sem lehet párhuzamba állítani, ezért eltérő elemzést javasol Burton-Roberts (1994)-re hivatkozva: a bennfoglalás mondatkoordinációt von maga után. A (106)-os példák származási helye: Heringa (2012: 64). 
(106) a. The children liked the animals, particularly the monkeys.

'A gyerekek szeretik az állatokat, különösen a majmokat.'

b. *Animals are particularly the monkeys.

* ‘Állatok különösen a majmok.’

c. The children like the animals and the children particularly like the monkeys.

'A gyerekek szeretik az állatokat, és a gyerekek különösen szeretik a majmokat.'

\subsubsection{Szórend}

Heringa (2012) amellett érvel, hogy az angolban a látszólag fordított appozíciós szerkezetekben is az értelmezett áll elöl, amint ezt a (107)-es példa is mutatja (Potts 2005: 137).

(107) a. A former linguist, Edward Witten, is now the top-dog in string theory. [angol] 'Egy egykori nyelvész, Edward Witten, most nagykutya a sorelméletben.'

b. Edward Witten, a former linguist, is now the top-dog in string theory.

'Edward Witten, egy egykori nyelvész, most nagykutya a sorelméletben.'

Ha (107a) valóban (107b) fordított változata lenne, azt várnánk, hogy az első elem nem része a mátrixnak, és így nem lép kölcsönhatásba a fömondat elemeivel. Az egzisztenciális there-rel való kontextusok azonban azt mutatják, hogy csak az első elem érzékeny (107a)-ban a mátrix mondatra a határozottsági hatás tekintetében, amint ez (108)-ban is látható (Potts 2005: 137).

(108) a. There was a former linguist at the party.

[angol]

'Volt egy egykori nyelvész a partin.'

b. There was a former linguist, Edward Witten, at the party.

'Volt egy egykori nyelvész, Edward Witten, a partin.'

c. \# There was Ed Witten at the party.

'Volt Ed Witten a partin.'

d. \# There was Ed Witten, a former linguist, at the party.

'Volt Ed Witten, egy egykori nyelvész a partin.'

Még egy érv felhozható amellett, hogy (108a)-ban is a második elem az appozíció: az információs szerkezet. Míg (108a) egy bizonyos egykori nyelvészről állít valamit, addig (108b) 
Edward Witten-ről nyújt plusz információt. Hogy ezen megnyilatkozások melyikét használjuk, a feltett kérdéstől függ. (Arra a kérdésre, hogy ki Edward Witten, (108b) jó válasz, míg (108a) nem.)

Ha az értelmezett szót az appozíciós szerkezet fejének tartjuk, akkor az elvárás az, hogy a fejvégű nyelvekben az értelmező álljon elöl. Az 1.2.4.1 pont alatti alrészben látni fogjuk, hogy az appozíciós szerkezeteket párhuzamba állíthatjuk az értelmezői vonatkozó tagmondatokkal. A fejvégü nyelvekben csak korlátozó prenominális vonatkozó tagmondat van, de a török nyelvet megvizsgálva Lehmann (1984) azt állítja, hogy a török posztnominális változatot használ az értelmezői vonatkozó tagmondatok esetében (109). A példa (Lehmann 1984: 144)-ből származik.

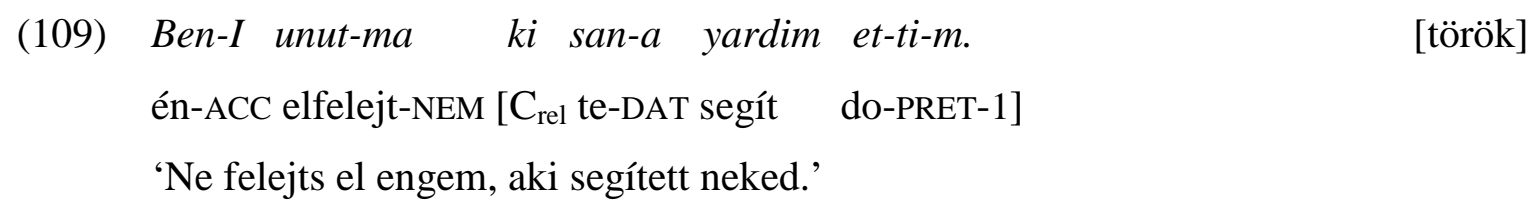

Heringa (2012) azt a konklúziót vonja le, hogy az appozíciós szerkezetekben ugyanaz a szerkezettagok sorrendje, vagyis az értelmezőnek és az értelmezői vonatkoztatásnak is követnie kell az antecedensét.

De Vries (2006) hipotézise, hogy csak korlátozó prenominális vonatkozó tagmondat van a fejvégű nyelvekben, prenominális nem-korlátozó értelmezők nem léteznek. Ezt arra alapozza, hogy az appozíciók és az értelmezői vonatkozások specifikálják az antecedensüket, és a specifikáció fogalmából kiindulva követniük kell az általuk specifikált elemet. A törökön kívül a baszk, a lahu és a nama nyelvben is található posztnominális értelmezői vonatkoztatás, miközben ezek a nyelvek a prenominális pozíciót használják a korlátozó vonatkoztatás kifejezésére.

Del Gobbo (2003) bemutatja, hogy az appozíciónak és az értelmezői vonatkozó tagmondatnak a kínaiban is követnie kell az értelmezettet (Del Gobbo 2003: 103).

(110) Zhangsan jiandao Daiyu, yi-ge hen piaoliang de guniang. [kínai] Zhangsan találkozik Daiyu egy-CL nagyon csinos DE lány 'Zhangsan találkozott Daiyuval, egy nagyon csinos lánnyal.' 
A japán appozíciós konstrukciókat megvizsgálva Heringa az $\left[\mathrm{NP}_{1} \mathrm{NP}_{2}\right]$-konstrukciót valódi értelmezőnek tartja, ezek a szerkezetek a japánban mindig nem-korlátozó olvasatot kapnak. A (111)-es példa származási helye Sode (2004: 31).
(111) Nihon saidai-no mizuumi, Biwa-ko [japán] Japán legnagyobb-GEN tó Biwa-tó
'Biwa-tó, Japán legnagyobb tava'

Az elemek szórendje miatt érdekesek ezek a példák. Az intonáció (vesszővel jelölve) és a fordítás azt sugallja, hogy $\mathrm{NP}_{2}$ közelebb van a jelölöhöz, mint $\mathrm{NP}_{1}$. Így inkább $\mathrm{NP}_{2}$ feleltethető meg az értelmezővel, amely itt követi az értelmezettet.

$\mathrm{Az}\left[\mathrm{NP}_{1}\right.$-EX $\left.\mathrm{NP}_{2}\right]$-konstrukció első pillantásra az angol bennfoglaló szerkezethez hasonlít. A (112)-es példa Sode (2004: 35)-ben található.
(112) Akitaken-nado oogataken-ni saikin ninki-ga aru. [japán] akiták-EX nagy.fajta.kutyák-DAT mostanság népszerüség-NOM bír 'Mostanság az akiták és más nagy testü kutyák népszerüvé válnak.'

Heringa mégis amellett érvel, hogy ezek a konstrukciók strukturálisan közelebb vannak az azonosítás és a tulajdonítás szemantikai osztályába tartozó appozíciókhoz. Emellett szóló érve, hogy a (112)-es szerkezet átalakítható a (113)-ban látható módon, míg ezek a parafrázisok az angol bennfoglaló appozíciók számára nem elérhetőek. A (113)-as példa származási helye Sode (2004: 38).

$$
\text { Oogataken-wa Akitaken-nado da. }
$$

[japán]

nagy.fajta.kutyák-TOP akiták-EX COP

'A nagytestü kutyák akiták és mások.'

\subsubsection{Az appozíciós szerkezet elemzése}

Az alábbiakban röviden ismertetem a nemzetközi szakirodalomban fellelhető megközelítéseket az appozíció szerkezeti elemzésével kapcsolatban. Három elemzési javaslatot fogok részletesebben bemutatni - a legfrissebb eredményekre koncentrálva. 
A nemzetközi szakirodalomban kétféle megközelítés létezik azt a kérdést illetően, hogy hogyan kapcsolódik egy közbevetés a mátrix tagmondathoz, illetve az értelmező az értelmezetthez. Az „árvaházi” (orphanage) megközelítés szerint nincs szintaktikai viszony az értelmező és az értelmezett között, az értelmező független a mátrix mondattól. ${ }^{15}$ Ezzel szemben az integrációs megközelítés szerint szerkezeti viszony van az értelmező és az értelmezett között.

\subsubsection{Korábbi elemzések}

Az azonosító értelmező nemzetközi szakirodalma igen gazdag és összetett képet mutat, és a magyar nyelvtanokhoz hasonlóan itt sincs egységes álláspont a szerkezet elemzését illetően.

Az appozíciós szerkezeteket elemezték mellérendelésként: Hockett (1955) a két elem ekvivalenciája miatt szimmetrikus viszonyt feltételez az appozíciós szerkezetben. Sturm (1986) amellett érvel, hogy az appozíció és a koordináció szintaktikailag megkülönböztethetetlen, az egyetlen különbség közöttük az interpretációban van. Az appozícióban a két tag közötti viszony az azonosítás, míg a koordinációban a viszony úgy interpretálható, hogy két különböző referens van felvéve.

Az appozíciót tekintették két mondat koordinációjának: Burton-Roberts (1975) szerint az appozíció két tagjának koreferenciális volta miatt a szerkezet nem elemezhető nominális koordinációként. Helyette két mondat koordinációját feltételezi: az 1. tagmondat tartalmazza az értelmezettet, a 2. tagmondat ugyanaz, kivéve, hogy az értelmezett helyett az értelmező jelenik meg, s a redundáns elemek törlődnek, hogy az értelmezett és az értelmező egymás mellé kerüljön. A mellérendelő kötőszó pozícióját pedig egy appozíció-jelölő töltheti ki.

A szerkezetet tekintették alárendelésnek is: Curme (1947) szerint az appozíció a jelzői módosítás típusa, az értelmezett a fej, és az értelmező az azonosító. Acuña-Fariña (1996a) az értelmezőt az értelmezett nem-korlátozó módosítójaként elemzi. Szerinte egy főnév korlátozó és nem-korlátozó módosítója közti különbség az, hogy a nem-korlátozó módosító egy magasabb szinten van, és ezáltal nemcsak a fejet módosítja, hanem annak a korlátozó módosítóját is. Doron (1994) az alárendelés altípusaként, predikációként elemzi az appozíciót. Ebben a predikatív viszonyban az értelmezett az alany, és az értelmezőnek van egy nominális predikátum jegye. Potts (2005) szerint az értelmezők jobbról csatolt adjunktumok az értelmezett mellett, s a vessző-jegy idézi elő a szerkezetben a predikatív interpretációt.

Az appozíciót egy harmadik típusú viszonyként is jellemezték: Sopher (1971) szerint az elemek közötti viszony nem koordináció, mivel azok koreferenciálisak. Ugyanakkor alárende-

\footnotetext{
${ }^{15}$ Az orphanage (,árvaházi”) terminust Safir (1986)-ból vette át Haegeman (2009).
} 
lés sem lehet a köztük lévő viszony, mivel az elemek funkcionálisan ekvivalensek, az alárendelés viszonyában azonban az elemeknek különféle szintaktikai funkciójuk van. DelormeDougherty (1972) egyetértenek ezzel. Peterson (1999) szerint az értelmezős szerkezet elemei nem alkotnak egy szintaktikai egységet, ezért nem állnak szintagmatikus viszonyban egymással. Az appozíció szintaktikailag nem része a mátrix mondatnak, csak szemantikailag és intonációsan kapcsolódik az értelmezetthez. Koktová (1986) szerint sem része az appozíció a szintaxisnak, inkább pragmatikai jelenség, mivel nem járul hozzá a mátrix mondat szemantikájához, annak igazságértékéhez, inkább csak preszuppozícióként szolgál.

A nemzetközi szakirodalomban több elképzelés is kapcsolatba hozza a (laza) értelmezős konstrukciókat a nem-korlátozó vonatkozó szerkezetekkel. Ezek a megközelítések két fő irányt képviselnek: az értelmezős szerkezetet vagy egy lecsökkentett vonatkozó tagmondatként (Smith 1964, Pollmann 1975), vagy egy appozíciós vonatkozásként (O’Connor 2008, Cardoso-De Vries 2010) kezelik. Az alábbi példa (Smith 1964: 42) azt illusztrálja, hogy egy értelmezői relatív kopulás tagmondatból a vonatkozó névmás és a kopula törlésével kapható meg egy appozíciós szerkezet (114).

(114) John, (who was) a good salesman, charmed them immediately. [angol] 'János, (aki) egy jó eladó (volt), azonnal elbűvölte őket.'

\subsubsection{Heringa (2012)}

Heringa (2012) az appozíció szerkezeti elemzése során az értelmező és a mátrix mondat közötti ambivalens viszonyra épít: az értelmező egyfelől szorosan kapcsolódik az értelmezetthez, a mátrix mondat egy eleméhez, másfelől az értelmező lazán kapcsolódik magához a mátrix mondathoz.

Az appozíció függetlenségét mutató jellemzők:

a) Az értelmező elkülönül a mátrix mondattól a vessző-intonáció által.

b) Az értelmező nem játszik szerepet olyan szintaktikai eljárásokban, mint az egyeztetés és a névmás interpretációja.

c) Az értelmezőnek saját propozíciója van, amely diskurzusviszonyba léphet a fő propozícióval.

d) Az appozíciónak lehet saját illokúciós ereje, időbeli referenciája és alárendelő kötőszava.

e) Az appozíció megjelenhet fókuszban egy kettéhasított (cleft) mondatban.

f) Az appozíció nem a fö predikátum argumentuma. 
g) Az appozíció kívül van a mátrix mondatban lévő kvantor hatókörén.

A fenti tulajdonságok alapján Heringa az appozíciót a közbevetések osztályába sorolja. A közbevetés (pl. értelmezői vonatkozó tagmondat, indulatszó közbevetése, megszólítás, idéző tagmondat, magyarázó tagmondat) lineárisan integrálva van egy vendéglátó mondatba, de strukturálisan bizonyos mértékig független.

Heringa amellett érvel, hogy a rejtett alanyi névmás az appozíciós tagmondatban egy Etípusú névmás, amelynek van egy kvantifikációs antecedense, még sincs strukturálisan kötve ezen elem által. Az E-típusú névmások tulajdonsága, hogy azon túl, hogy utalnak az antecedensre, még a kontextust is számításba veszik, ahogyan ezt Evans (1980: 339) példája mutatja (115).

(115) Few congressmen admire Kennedy, and they are very junior. [angol]

'Kevés képviselő csodálja Kennedyt, és ők nagyon fiatalok.'

A (115)-ös példában a they 'ők’ nemcsak a kevés képviselöre utal, hanem azokra a képviselőkre, akik csodálják Kennedyt.

Másfelől az appozíció modális alárendelést mutat a mátrix mondatra nézve, illetve szomszédosnak kell lennie az értelmezettel (kivétel, amikor az értelmezőt kiemeljük a mondat jobb perifériájára), ezek a jellemzők az appozíció főmondatba való integrálását illusztrálják. A (116)-os példák Roberts (1996: 216)-ból származnak.

(116) a. You should buy a lottery ticket ${ }_{i}$ and put it in a safe place.

'Venned kellene egy sorsjegyet, és egy biztonságos helyre kellene tenned.'

b. \# It $t_{i}$ 's worth a million dollars.

\# 'Ez egymillió dollárt ér.'

c. It $t_{i}$ might be worth a million dollars.

'Ez egymillió dollárt érhet.'

A (116a, b) adatok azt példázzák, hogy a névmások ugyanazon a mondaton belül létrehozhatnak anaforás viszonyt a határozatlan DP-vel, de a mondaton kívüli névmások, a kvantifikációs elem hatókörén kívül esve már nem tudnak anaforás viszonyba lépni a DP-vel. (116a, c)-ben azonban a mondathatár ellenére létrehozható egy anaforás viszony, mivel a (116c) is tartalmaz egy kvantifikációs elemet, amelynek a hatóköre alatt lévő dolog szemantikailag alá van ren- 
delve az előző diskurzus intenzionális kontextusának. Ezt nevezik modális alárendelésnek. (Nemcsak a modális igék, hanem az attitüdigék mellett is megfigyelhető ez a jelenség.)

(117)-ben a kvantifikációs határozószó (usually) egy intenzionális operátorként működik, létrehozva egy anaforás kapcsolatot a határozatlan nominális elem (amely az every kvantor hatóköre alatt van) és a rejtett névmás között az appozíciós üzenetben. Így az értelmezett és az értelmező közti határ hasonló a mátrix mondat és a modális alárendelés közti viszonyhoz. (Az appozíció modális alárendelésként való elemzése megmagyarázza azokat az adatokat, amelyek első pillantásra hatóköri viszonyt sugallnak egy értelmező és a mátrix mondat között.) A (117)-es példát Doron (1994: 60) vette át Sells (1985)-böl.

(117) Every rice farmer in Korea owns a wooden cart, usually a rickety old thing.

'Minden koreai rizstermelőnek van egy fából készült kordéja, rendszerint egy régi, rozoga holmi.'

A közbevetésnek a mátrix mondattól való függetlensége a szintaktikai szerkezetből ered, ha a közbevetés nincs k-vezérelve a mátrix mondat bármely eleme által. Ugyanakkor integrációs jelenség is megfigyelhető: a szomszédossági követelmény miatt az appozíció egy összetevőt alkot az értelmezettel. Heringa célja egy olyan szerkezet létrehozása, amellyel egyidejüleg leírható a függőség és a függetlenség, ezért kétféle mủveletet különböztet meg: a dominancia összeolvasztást (dominance Merge, 118a) és a kiegészítő összeolvasztást (supplementation Merge, 118b).

(118) a. dominancia összeolvasztás<smiles>BCC</smiles>

b. kiegészítő összeolvasztás

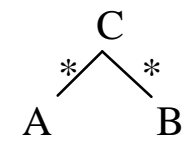

A kiegészítő összeolvasztás műveletének a lényege, hogy általa az appozíció egy összetevőt alkot az értelmezettel, ugyanakkor sem az értelmezett, sem más elem a mátrix mondatban nem k-vezérli az értelmezőt, mert a kiegészítés blokkolja ezt a viszonyt, mivel az ily módon egyesített összetevők egy eltérő dimenzióba kerülnek, s láthatatlanná válnak a többi elem számára. A kiegészítő összeolvasztás művelete megtöri a dominancia tranzitivitását, és így blokkolja a k-vezérlést.

A főmondathoz nem lehet közvetlenül hozzákapcsolni a közbevetést, mert akkor a közbevetéshez kapcsolódó elemek is láthatatlanná válnának a mátrix mondat elemei számára. De 
Vries (2012) egy ParP funkcionális projekciót javasol a probléma megoldására, amely már integrálható a dominancia összeolvasztás müvelete által a mátrix mondatba, míg a ParP-n belül az értelmező a kiegészítő összeolvasztás által kapcsolódik az értelmezett szóhoz.

(119)

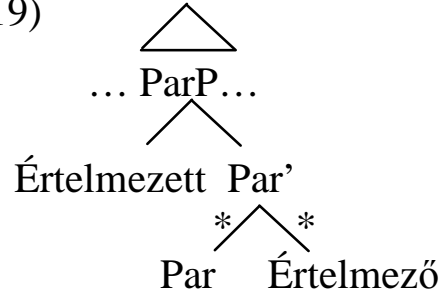

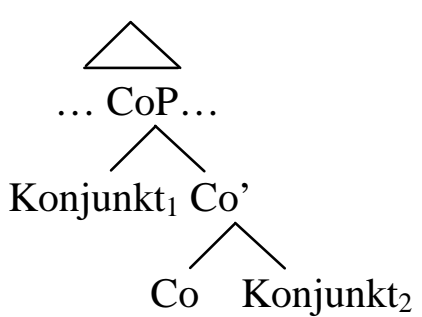

Ez a szintaktikai szerkezet megmagyarázza az appozíciós konstrukció paradox természetét. Az appozíció és a koordináció hasonlósága is megmutatható: az appozíció-jelölők a Par-fejbe kerülnek, az értelmezett szó és az értelmező esete megegyezik, továbbá léteznek többszörös appozíciós szerkezetek. Ugyanakkor Heringa (2012) előző konklúziója az volt, hogy az appozíció predikatív, alárendelt viszonyban áll az értelmezettel. E két viszony kombinációja a (120)-as szerkezet.

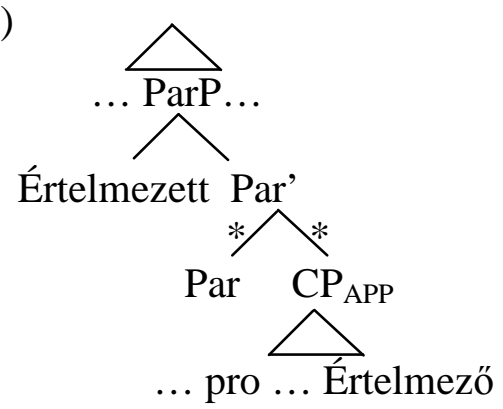

\subsubsection{Az azonosító értelmező szerkezete Griffiths-De Vries (2012) alapján}

De Vries $(2009,2012)$ egy olyan integrációs megközelítés mellett érvel, amely szerint az értelmező közbevetve van koordinálva az értelmezetthez, mégpedig egy szintaktikai funkcionális fej által (Par), ahogyan ez látható (119)-ben is.

(121) [host_clause [ParP [DP John] [Par' $\operatorname{Par}^{0}$ [who is my neighbour]]] is a good guy]. 'John, aki a szomszédom, egy jó fiú.'

Griffiths-De Vries (2012) elvetik az appozíciós vonatkozó mondatok jobb-adjunkciós elemzését, mert ez nem magyarázza meg a hatóköri függetlenséget a (122)-es példában. 


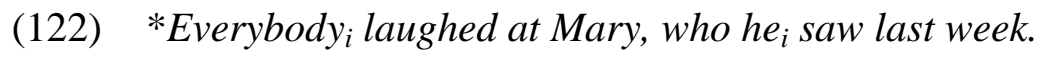

'Mindenki $i_{\mathrm{i}}$ kinevette Maryt, akit a múlt héten pro $_{\mathrm{i}}$ láttak.'

Griffiths-De Vries (2012) megközelítésében a közbevetési projekció beolvasztása blokkolja a k-vezérlést.

Az elemzés előnyei: i) Megmagyarázza, hogy az értelmezett és az értelmező miért szomszédos (ez kevésbé világos az ,árvaházi” megközelítésben).

ii) A Par-fej egy szükséges szintaktikai fej Potts (2005) „vessző-jegye”, vagyis egy szemantikai operátor számára, amely azt az információt nyújtja, hogy az értelmező másodlagos a vendéglátó tagmondat által denotált propozícióhoz képest.

iii) Egy olyan szintaktikai integrációs megközelítés, mint a ParP feltevése, azt jósolja, hogy a közbevetések rekurzívan létrehozhatók (123).

(123) I like linguists, who study language, such an intriguing phenomenon, as you know, and in particular syntacticians, the most intelligent of all.

[angol]

'Kedvelem a nyelvészeket, akik tanulmányozzák a nyelvet, mint egy érdekes jelenséget, amint tudod, és föleg a szintaktákat, mind közül a legintelligensebbeket.'

Az értelmezők belső szerkezetét nem vizsgálják, csak a közbevetés és a mátrix tagmondat közti kapcsolatra fókuszálnak. Ehhez az appozíciós vonatkozó tagmondatokat és a hozzájuk köthető töredékválaszokat veszik alaposan szemügyre, amely utóbbit elliptikus szerkezetnek tartják.

Egy appozíciós vonatkozó tagmondat értelmezhet egy nominális összetevőt (124a) vagy egy tagmondatot (124b).

(124) a. John stole [Mary's computer, which crashes all the time]. [angol]

'John ellopta Mary számítógépét, amely állandóan tönkrement.'

b. [John stole Mary's computer, which got him arrested].

'John ellopta Mary számítógépét, amiért letartóztatták őt.'

Kérdések kontextusában tesztelték a fenti mondatokat. Ha a kérdés egy direkt tárgyi töredékválaszt vár (125a), akkor egy tárgyi vonatkozású appozíciós vonatkozó tagmondat jelenik meg (125a(i)), de a tagmondati vonatkozású appozíciós vonatkozó tagmondat (124a(ii)) is jó. 
Ha a kérdés alanyt von maga után (125b), a tárgyi vonatkozású appozíciós vonatkozó tagmondat (125b(i)) elfogadhatatlan válasz.

(125) a. A: What did John steal?

'Mit lopott el John?'

B: (i) Mary's computer, which crashes all the time.

'Mary számítógépét, amely állandóan elromlott.'

(ii) Mary's computer, which got him arrested.

'Mary számítógépét, amiért letartóztatták.'

b. A: Who stole Mary's computer?

'Ki lopta el Mary számítógépét?'

B: (i) *John (did), which crashes all the time.

*'John (tette), amely állandóan elromlik.'

(ii) John (did), which got him arrested.

'John (tette), amiért letartóztatták öt.'

A fentiek alapján azt a következtetést vonták le, hogy egy appozíciós vonatkozó tagmondat a felszínen csak egy olyan értelmezett mellett jelenhet meg, amely legalább részben nyílt.

A fenti adatok eredményeit további példákkal támasztják alá (126). Az értelmezői tagmondat (126a)-ban vonatkozhat a tárgyi DP-re (Mari számítógépére) és a tagmondati propozícióra (a számítógép ellopásának eseményére) is. Ez a kétértelmüség megmarad a tárgyi töredékválasz esetében (126b), míg ha a törölt rész tartalmazza a tárgyi DP-t, csak a propozíciós olvasat lesz elérhető (126c).

(126) a. John stole Mary's computer, which is awful.

'John ellopta Mary számítgépét, ami szörnyü.'

b. A: What did John steal?

'Mit lopott el John?'

B: Mary's computer, which is awful.

'Mary számítógépét, ami szörnyü.'

c. A: Who stole Mary's computer?

'Ki lopta el Mary számítógépét?'

B: John (did), which is awful.

'John (tette), ami szörnyü.' 
Az alábbi szintaktikai integrációs elemzést rendelik az egyes mondatokhoz, ellipszissel kombinálva: A propozíciós olvasat esetében (127-128) az értelmezői vonatkozó tagmondat egy teljes CP-t vesz fel értelmezettjeként. Az ellipszis C'-t célozza meg, miközben az elliptált részek visszanyerhetők az előző kérdésekből. ${ }^{16}$

A: What did John steal?

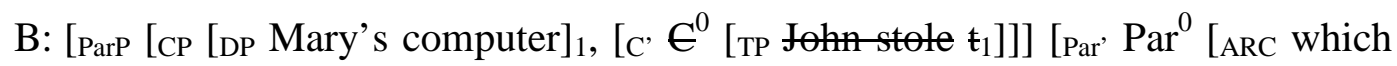
got him arrested]]].

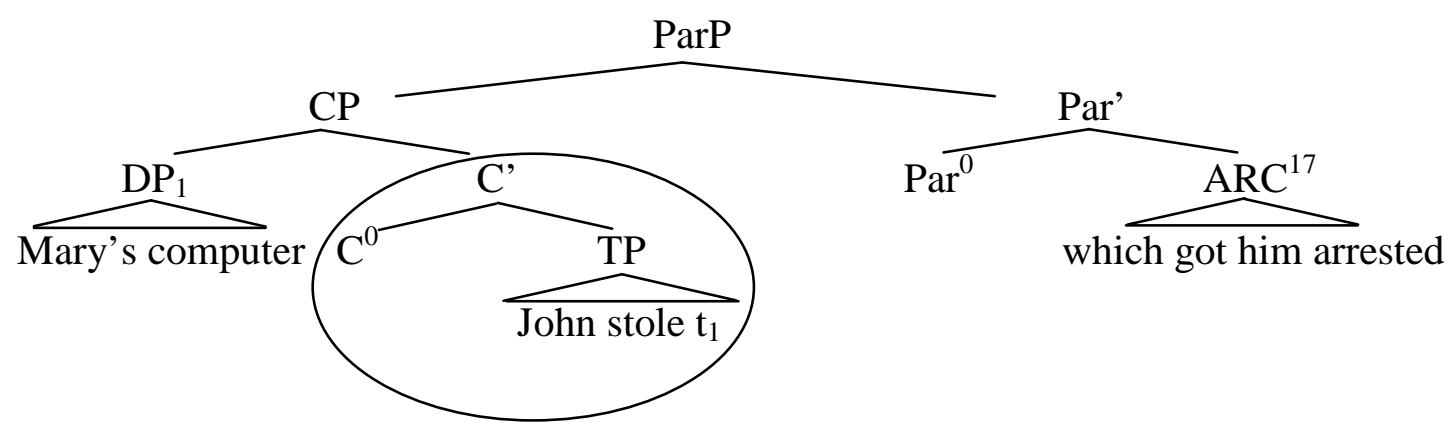

(128) A: Who stole Mary's computer?

B: [ParP [CP [DP John $]_{1},\left[\mathrm{C}^{\prime} \mathrm{C}^{0}\left[\mathrm{TTP}_{\mathrm{t}}\right.\right.$ stole Mary's cemputer] $\left.]\right]$ [Par' Par $^{0}$ [ARC which got him arrested]]]

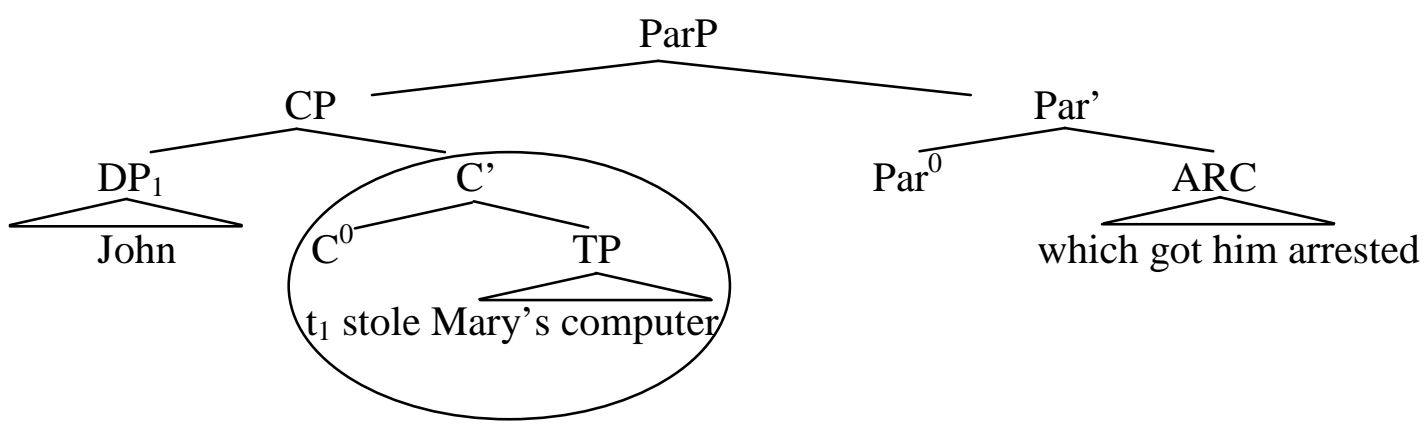

A nominális összetevős olvasat esetében (129-130) az értelmező vonatkozó tagmondat egy főnévi frázist vesz fel az antecedenseként. Ebben az esetben a ParP fókuszmozgatáson megy keresztül, és C' törlése következtében a direkt tárgy - az értelmezői vonatkoztatással kombinálva - töredékválaszként jelenik meg. A (130)-ban látható elemzést azért zárják ki, mert az ellipszis egy nem-összetevőt célozna meg, ami nem lehetséges.

${ }^{16}$ A (127-129)-es példákban zsilipelés történik, vagyis a fókusz utáni összetevöt töröljük. Az ellipszis elvégzése elött a törölni nem kívánt összetevő fókuszmozgatáson megy keresztül. A zsilipelésről a 2.5.2.2 pont alatti alrészben bővebben is lesz szó.

${ }^{17} \mathrm{ARC}=$ appositive relative clause (appozíciós vonakozó tagmondat) 
A: What did John steal?

B: [CP [ParP [DP Mary's computer] [Par' $\operatorname{Par}^{0}[\text { ARC which crashes all the time] }]_{1}\left[\mathrm{C}, \mathbf{C}^{0}\right.$ [TP John stole $\left.\left.\mathrm{t}_{1}\right]\right]$.

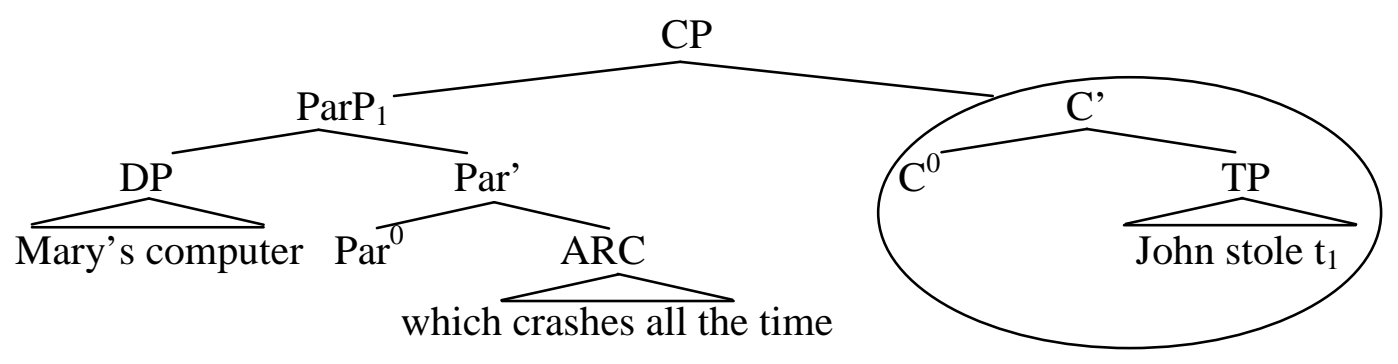

(130) A: Who stole Mary's computer?

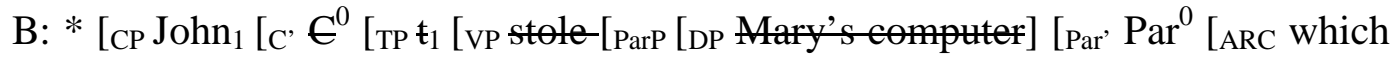
crashes all the time]]]]]]].

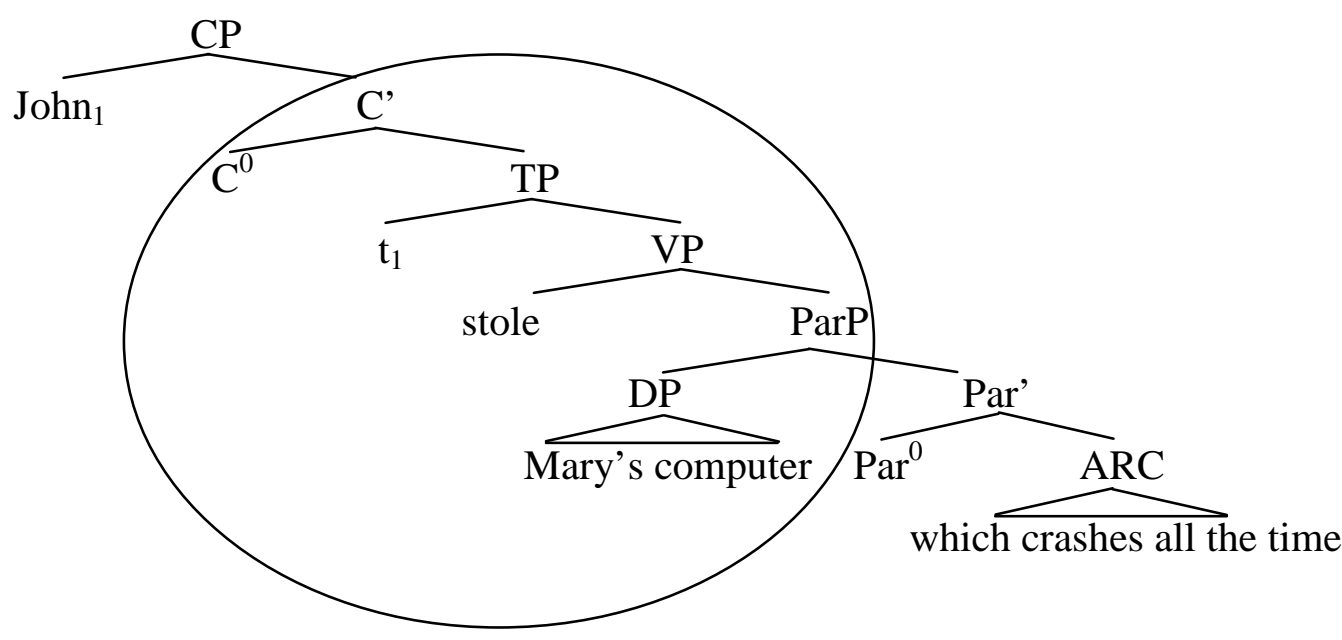

(kizárva)

A ParP-megközelítés az alábbi példákban is megmagyarázza, hogy az ellipszis miért vezet egyértelműséghez (131b, c)-ben, míg (131a)-ban nem: az elliptált résznek szemantikailag értelmezhetőnek kell lennie (vagyis a kontextusból visszanyerhetőnek).

(131) a. A: What did John steal?

B: Mary's computer, which is awful.

(i) $\left[\mathrm{CP}\left[\mathrm{ParP}[\mathrm{DP} \text { Mary's computer }]\left[\mathrm{Par}^{\prime} \operatorname{Par}^{0}[\mathrm{ARC} \text { which is awful }]\right]\right]_{1}\right.$ [C, $\in^{0}$ [тр John-stele $\left.\left.\mathfrak{t}_{1}\right]\right]$.

(ii) $\quad\left[\mathrm{ParP}\left[\mathrm{CP}[\mathrm{DP} \text { Mary's computer }]_{1}\left[\mathrm{C}^{\prime} \mathrm{E}^{0}\left[\mathrm{TP}\right.\right.\right.\right.$ John stole $\left.\left.\left.\mathrm{t}_{1}\right]\right]\right]\left[\mathrm{Par}^{\prime} \mathrm{Par}^{0}\right.$ [ARC which is awful]]].

b. A: Who stole Mary's computer?

B: John, which is awful. 
(i) $\quad\left[\mathrm{ParP}\left[\mathrm{CP}[\mathrm{DP} \text { John }]_{1}\left[\mathrm{C}^{\prime} \mathrm{C}^{0}\left[\mathrm{TP}_{\mathrm{t}} \mathfrak{\ddagger}_{1}\right.\right.\right.\right.$ stole Mary's computer $\left.\left.]\right]\right]\left[\mathrm{Par}^{\prime} \mathrm{Par}^{0}\right.$ [ARC which is awful]]].

(ii) $*{ }_{\mathrm{CP}} \mathrm{John}_{1}\left[{ }_{\mathrm{C}}, \mathrm{C}^{0}{ }_{\mathrm{TP}} \mathbf{t}_{1}\right.$ [vP stole-[ParP [DP Mary's computer] [Par' $\operatorname{Par}^{0}[$ ARC which is awful]]]]]]].

c. A: Did John steal Mary's computer?

B: Possibly, which is awful.

(i) $\quad\left[\right.$ ParP $\left[\mathrm{CP}\right.$ Possibly [C, $\mathrm{E}^{0}\left[\mathrm{TP} \mathfrak{t}_{1}\right.$ John stole Mary's computer $\left.]\right]$ [Par' $\operatorname{Par}^{0}$ [ARC which is awful]]].

(ii) * [ ${ }_{\mathrm{CP}}$ Possibly [C, $\mathrm{C}^{0}$ [TP John [vp stele-[ParP [DP Mary's computer] [Par' $\operatorname{Par}^{0}[$ ARC which is awful]]]]]]].

(131a)-nak két olvasata van: az összetevős olvasat szerkezete a (129)-es ágrajzzal, míg a propozíciós olvasat szerkezete a (127)-es ágrajzzal adható vissza.

(131b)-nek csak propozíciós olvasata van, mint a (130)-ban bemutatott példának. A lehetetlen összetevős olvasat szerkezete a (130)-as ágrajznak felel meg, amely azért nem lehetséges, mivel egy nem-összetevő ellipszisét vonná maga után.

(131c)-nak szintén csak propozíciós olvasata van a fenti okokból.

Azt a konklúziót vonhatjuk le, hogy Griffiths-De Vries (2012) - elliptikus környezetben vizsgálva az appozíciós szerkezeteket - bizonyítékot találtak arra, hogy az értelmező egy összetevőt alkot az értelmezettel.

\subsubsection{Ott (2014)}

Ott (2014) a nem korlátozó nominális appozíciókat vizsgálja, amelyeket közbevetésnek tart, és nem adjunktumoknak. Két típusát különbözteti meg: a specifikációs nominális appozíció esetében az értelmező specifikálja, azonosítja az értelmezett szót (132a), míg a predikációs nominális appozícióban az értelmezö valamilyen tulajdonságot rendel az értelmezetthez (132b).

(132) a. I met an old friend, John Smith, at the pub today.

'Találkoztam egy régi barátommal, John Smith-szel ma a kocsmában.'

b. I met John Smith, my best friend, at the pub today.

'Találkoztam John Smith-szel, egy régi barátommal ma a kocsmában.' 
A szerkezetet úgy elemzi a belső szintaxist tekintve, hogy mindkét típusnál PF-törlést javasol, a nominális appozíció alapjául szolgáló tagmondatból elliptál bizonyos részeket. A külső szintaxist illetően amellett foglal állást, hogy az appozíciónak a vendéglátó mondatba való integrációja nem szintaktikai, hanem diskurzusbeli.

Először nézzük meg a specifikációs appozíció szerkezeti elemzését. Az appozíció felszíni maradéka egy alapul szolgáló párhuzamos tagmondatnak, amelyből a redundáns elemeket töröljük PF-en (133).

(133) a. [CP1 I met [C an old friend] at the pub today]

b. [CP2 I met [A John Smith] at the pub today] $\rightarrow$ törlés [CP2 Imet [A John Smith] at the pub today]

c. [CP1 I met [C an old friend]

[CP2 Imet [A John Smith] at the pub today] at the pub today]

A predikációs appozíció esetében az értelmező egy lecsökkentett predikációs kopulás tagmondat predikatív NP-je (134).

(134) a. [CP1 I met [C John Smith] at the pub today]

b. [CP2 he is [A my best friend] $\rightarrow$ törlés

[CP2 he is [A my best friend]]

c. [CP1 I met [C John Smith]

[CP2 he is [A my best friend]]

at the pub today]

A kétféle szerkezettel meg tudjuk magyarázni a specifikációs és a predikációs appozíció közti különbségeket a tagmondati tulajdonságaikat illetően. A predikációs értelmező módosítható (135), míg a specifikációs értelmező nem (136).

(135) a. Keith, (once) a drug addict, now leads a rehab clinic.

'Keith, egykori drogfüggő, most egy rehabilitációs klinikát vezet.'

b. [СР2 he was once a drug addict]

‘ø̋ egykor egy drogfüggő volt’ 
(136) a. A drug addict, (*once) Keith, now leads a rehab clinic.

'Egy drogfüggő, (*egykor) Keith most egy rehabilitációs klinikát vezet.'

b. *[CP2 once Keith now leads a rehab clinic]

* ‘egykor Keith most egy rehabilitációs klinikát vezet’

A magyar példák azonban nem támasztják alá ezt a fajta megkülönböztetést, ahogyan látni fogjuk a 3.1 pont alatti alfejezetben, ahol bemutatom, hogy a specifikációs értelmezők is módosíthatók.

A specifikációs appozíció esetében meg kell egyeznie a két tagmondat igazságértékének, különben ellentmondást kapunk (137), vagyis ha igaz, hogy Mari egyik bátyjának van egy barátnője, akkor annak is igaznak kell lennie, hogy Péternek van egy barátnője. Ezzel szemben a predikációs appozíció esetében a két tagmondat egymástól függetlenül lehet igaz vagy hamis anélkül, hogy ez ellentmondáshoz vezetne (138), vagyis ha igaz, hogy Péternek van egy barátnője, attól még lehet hamis, hogy Péter Mari egyik bátyja, és fordítva, ha nem igaz, hogy Péternek van egy barátnője, attól még igaz lehet, hogy Péter Mari egyik bátyja.

(137) One of Mary's brothers, Peter, has a girlfriend. [angol]

'Mari egyik bátyjának, Péternek van egy barátnője.'

a. [CP1 [NP one of Mary's brothers $]_{i}$ has a girlfriend]

b. $\left[\mathrm{CP}_{2}\left[{ }_{\mathrm{NP}} \text { Peter }\right]_{\mathrm{i}}\right.$ has a girlfriend $]$

(138) Peter, one of Mary's brothers, has a girlfriend. [angol]

'Péternek, Mari egyik bátyjának van egy barátnője.'

a. [CP1 Peter has a girlfriend]

b. [ $\mathrm{CP} 2$ he is one of Mary's brothers]

A specifikációs appozíció megegyezik a $\theta$-szerepet és az esetet tekintve az értelmezettel (139), míg a predikációs appozíció predikatív esetet visel (140).

(139) a. Sie haben einem von den Typen, dem Peter, geholfen zu flüchten. ők AUX egy.DAT GEN a fiúk a.DAT Péter segített INF elmenekül 'Segítettek a srácok egyikének, Péternek, elmenekülni.' [német]

b. Ja videl doč Lavrova, Katju, včera $v$ Moskve. én látott lánya.ACC Lavrov.GEN Katja.ACC tegnap IN Moszkva 'Láttam Lavrov lányát, Katjat tegnap Moszkvában.' 
(140) Sie haben dem Peter-(angeblich) ein Obdachloser aus Köln-mit ök AUX a.DAT Péter állítólag egy.NOM hajléktalan ELA Köln INSTR

einer Spende geholfen. [német]

egy adomány segített

'Adománnyal segítettek Péternek, (állítólag) egy hajléktalan embernek Kölnböl.'

Ott (2014) szerint a specifikációs és a predikációs értelmezőhöz rendelt szerkezetek magyarázatot adnak az esetragok eltérő viselkedésére a kétféle appozícióban. 


\section{A HÁTRAVETETT JELZŐI ÉRTELMEZŐ}

Ebben a fejezetben - a magyar leíró nyelvészetben hagyományos terminussal élve - a hátravetett jelzői értelmezővel kapcsolatos kutatásom eredményeit fogom bemutatni. Először a szerkezet tulajdonságait ismertetem, kiegészítve, illetve módosítva a leíró nyelvtanok állításait. Ezt követően megvizsgálom az értelmezett szó és az értelmező közötti egyezést. Külön kitérek arra a kérdésre, amelyet a korábbi nyelvtanok nem vizsgáltak: bármely melléknév és számnév esetében előállítható-e a hátravetett jelzői értelmezős szerkezet. A vizsgált konstrukciót párhuzamba állítom a görög nyelvben található úgynevezett 'polydefinite' szerkezettel, megvilágítva, hogy a látszólagos hasonlóságok mellett milyen különbségek szólnak az ellen, hogy a két szerkezetet azonos módon elemezzük. Végül egy újfajta szerkezeti elemzést mutatok be, a hátravetett jelzői értelmezőt két tagmondat koordinációjaként és az azokon végrehajtott ellipszisként elemezve.

\subsection{A hátravetett jelzői értelmező tulajdonságai}

A leíró nyelvtanok egyes állításai módosításra, kiegészítésre szorulnak a hátravetett jelzői értelmező tulajdonságait illetően. Az alábbiakban Szőke (2014b) alapján sorra veszem az egyes jellemzőket, amelyek a vizsgált szerkezet leírását szolgálják.

A leíró nyelvtanok úgy jellemzik a hátravetett jelzői értelmezöt, hogy az átalakitható elöl álló jelzövé. Az „átalakítás”18 fogalmát azonban nem határozzák meg pontosabban, az alábbi példák jelzik, hogy nem elég az értelmezett szó és az értelmező sorrendjét felcserélni (1).
a. az almát, a zöldet $\rightarrow *$ * zöldet almát
b. a fiúk, az erösek $\rightarrow *$ az erösek fiúk
c. a barátommal, az enyémmel $\rightarrow *$ az enyémmel barátommal
d. a kabátot, Péterét $\rightarrow *$ * Péterét kabátot

Szuffixumot viselő szerkezet esetén az értelmező kizárólag ragok (1a, c, d) és jelek (2b-d) nélkül jelenhet meg elöl álló jelzőként. Ha pedig a birtokjeles értelmezőből akarunk létrehozni elöl álló jelzőt, akkor az ,átalakítás” után az értelmezett szón meg kell jelennie a birtokoltságjelnek is $(2 \mathrm{~d})$.

\footnotetext{
${ }^{18}$ A hagyományos nyelvtanok az átalakítás fogalmát használják e jelenség körülírására, amely azonban nem feleltethető meg a generatív grammatikában használatos transzformáció fogalmának.
} 
(2)
a. az almát, a zöldet $\rightarrow$ a zöld almát
b. a fiúk, az erösek $\rightarrow$ az erös fiúk
c. a barátommal, az enyémmel $\rightarrow$ az én barátommal
d. a kabátot, Péterét $\rightarrow$ a Péter kabátját

A leíró nyelvtanok kiemelik az értelmezős konstrukció azon tulajdonságát, mely szerint átalakítható ${ }^{19}$ alany-állítmányi szerkezetté. Az alábbi példák azonban azt mutatják, hogy ezt az állítást pontosítani kell (3).
a. a csizmát, a pirosat $\rightarrow *$ a csizmát pirosat
b. a sportolónak, a gyöztesnek $\rightarrow *$ a sportolónak gyöztesnek

A szerkezet tagjai csak úgy kerülhetnek alany-állítmányi viszonyba, ha nem viselnek látható esetvégződést (az alanyként megjelenő értelmezett szó legfeljebb nominatívuszi esetet viselhet, míg az értelmező predikátumként semmilyen esetben sem állhat $(4 \mathrm{a}, \mathrm{b})){ }^{20}$
a. a csizmát, a pirosat $\rightarrow$ a csizma piros
b. a sportolónak, a gyöztesnek $\rightarrow$ a sportoló gyöztes

A fenti állítás azonban továbbra is módosításra szorul, ahogyan ezt az alábbi példák is megvilágítják (5).
a. a miniszterelnök, a hajdani $\rightarrow *$ a miniszterelnök hajdani
b. a fiúkat, mind a hármat $\rightarrow *$ a fiúk mind a három

A fenti példák alapján a következő megállapítást tehetjük: a nem metszetképző melléknévi (5a) és a számnévi (5b) értelmezős szerkezet két tagjából nem lehet predikatív viszonyt létrehozni.

\footnotetext{
${ }^{19}$ Az átalakítás fogalma itt sem egyezik meg a generatív nyelvészetben használatos transzformáció fogalmával.

20 A létige viselkedéséből adódik az a jelenség, hogy ha az értelmezős szerkezetben 1. vagy 2. személyü személyes névmás szerepel (ia, b), akkor a konstrukcióból csak egy létige segítségével hozható létre predikatív viszony (ic, d).

(i) a. te, a barátom $\rightarrow *$ te a barátom

b. én, a legerösebb $\rightarrow$ *én a legerösebb

c. te, a barátom $\rightarrow$ te a barátom vagy

d. én, a legerösebb $\rightarrow$ én a legerösebb vagyok
} 
Az alany-állítmány viszonyra vonatkozó megállapítás azonban további megszorításra szorul a felsőfokú melléknevek miatt, ahogyan azt a következő példa (6) is mutatja.
a. Kiválasztottam a ruhádat, a legszebbet.
b. *A ruhád legszebb.
c. A (kiválasztott) ruhád a legszebb. ${ }^{21}$

A felsőfokú melléknevek önállóan nem tölthetik be az állítmány szerepét (6b), a szerkezetet a határozott névelő megjelenése teszi grammatikussá (6c), amely arra utal, hogy egy DP, és nem egy AdjP alkotja a predikátumot. ${ }^{22}$ Tehát felsőfokú melléknévi értelmező esetén az értelmezős konstrukcióból csak úgy lehet alany-állítmányi szerkezetet létrehozni, ha a melléknevet egy határozott névelőjü DP-be helyezzük, amelynek a fönévi feje elliptálva van.

A hátravetett jelzői értelmezőknek fontos tulajdonsága, hogy az értelmezett szót korlátozzák. Jakab (1978) megszorítónak nevezi ezen jellemző miatt az értelmezős szerkezeteket. A magyar hátravetett jelzői értelmezők korlátozó voltát Kolliakou (2004) tesztjének alkalmazásával fogom bizonyítani (7).

(7) János szüretelni volt. Az almák, a zöldek nagyon finomak voltak.

a. János almát szüretelt, és voltak az almák között zöldek és nem zöldek.

b. János almát és más gyümölcsöt is szüretelt, és voltak közöttük zöld és nem zöld almák is.

c. János almát szüretelt, és csak zöld almák voltak.

d. János almát és más gyümölcsöt is szüretelt, de az almák mind zöldek voltak.

A minősítő - illetve a hátravetett jelzői - értelmező korlátozó volta mellett szól, hogy (7) esetében a c) és d) forgatókönyvek nem tünnek konzisztensnek a kiinduló példamondattal.

Az adatok körét alaposan megvizsgálva felmerülhet a következő kérdés: mi a helyzet az alábbi példákkal (8-9), ha azokat abból a szempontból vizsgáljuk meg, hogy korlátozóak-e. Néz-

\footnotetext{
${ }^{21}$ A felsőfokú melléknév nem ugyanazt a jelentést hívja elő, ha jelzőként, illetve predikátumként jelenik meg: $a$ legszebb ruhád $\neq$ a ruhád a legszebb. Ez a felsőfokú melléknév szemantikai-pragmatikai tulajdonságával magyarázható: a legszebb ruhád = a ruháid közül a legszebb; a ruhád a legszebb = a szóba jöhetö dolgok közül a ruhád a legszebb (Kiefer 1983).

${ }^{22}$ A felsőfokú melléknevek nemcsak a predikátum szerepét nem tölthetik be önállóan megjelenve, hanem hátravetett jelzői pozícióban sem állhatnak névelö nélkül (erre a 2.3.1 pont alatti alfejezetben hozok példákat).
} 
zük meg először a (8a, b) példákat, amelyek nem tünnek korlátozónak, bár első pillantásra itt is hátravetett jelzői értelmezővel van dolgunk.

a. a lányom, az a nagyokos

b. a férjem, a szerencsétlen / az idióta

$$
\text { A feleségem, a szorgalmas minden nap kitakarít, és vacsorával vár otthon. }
$$

(8a, b)-ben valójában nem melléknevek szerepelnek, hanem főnevek, ezért ezek azonosító értelmezők. A következő érvet hozhatjuk fel amellett, hogy a nagyokos, a szerencsétlen és az idióta szófaja főnév is lehet: betölthetik alany szerepét határozatlan főnévi csoportban megjelenve (10a), míg a csak melléknevek nem (10b).
a. Bejött egy nagyokos / egy szerencsétlen / egy idióta.
b. Bejött *egy szép / *egy okos.

Most pedig vizsgáljuk meg a (9)-es példát abból a szempontból, hogy korlátozó-e a benne található értelmező. Ez a mondat csak egy olyan kontextusban képzelhető el, ahol megengedett a többnejüség, és a férj arról a feleségéről beszél, aki szorgalmas. Nem korlátozó értelemben nem használható ez a megnyilatkozás.

Cs. Nagy Lajos Nyelvtani elemzési gyakorlókönyvében (1991) további olyan példák is találhatók, amelyeket a hátravetett jelzői értelmező alá kellene besorolnunk, mégsem nevezhetők korlátozónak (11). Ezekre a példákra később még visszatérek a 4.2 .1 pont alfejezet alatt.

(11) a. A nagy höségben üdítő́t sokat megisznak.

b. A beteg kompótot bármilyet és bármennyit megehet.

c. Kiflit akármennyit vehetsz.

d. Almát többet is ehetsz.

Összefoglalva az eddigieket, elmondható, hogy pontosításra szorult az átalakítás fogalma, amely során a hátravetett jelzői értelmezőből elöl álló jelzőt lehet létrehozni. Láthattuk azt is, hogy módosítani kellett azt az állítást is, amely szerint az értelmezős konstrukció átalakítható alany-állítmányi szerkezetté, mivel egyrészt e művelet során meg kell fosztani a szerkezettagokat az esetvégződésektől, másrészt nem is lehetséges minden hátravetett jelzői ér- 
telmezős szerkezet esetében az átalakítás. A hátravetett jelzői értelmezőknek igen fontos és nagyobb hangsúlyt érdemlő tulajdonsága a korlátozó értelem, mivel ez egy újabb eltérés az azonosító értelmezőkhöz (legalábbis a laza értelmezőkhöz) képest.

\subsection{Egyezés a hátravetett jelzői értelmezős szerkezetben}

Az 1.1.3.3 pont alatt már megemlítettem, hogy a leíró nyelvtanokkal szemben az egyezés (sharing) fogalmát használom az egyeztetés (agreement) helyett, amely utóbbi az alárendelt szerkezetben megjelenő tagok szuffixumainak megegyezését írja körül. Mivel feltételezésem szerint a hátravetett jelzői értelmezős szerkezetben nem alárendelés van, ezért az egyezés terminusát kívánom használni a vizsgált jelenség leírására.

\subsubsection{Egyezés az esetragokat tekintve}

Kiefer (1998) alapján 18 esetragot vehetünk fel az értelmezett szó és az értelmezett esetvégződésének egyezését vizsgálva. Kiefer nem esetragnak tekinti a következőket, hanem képzőnek a (12f) kivételével:
a. -kor temporalisi toldalék
b. -stUl sociativusi toldalék
c. $-(V) n t A$ distributiv-temporalisi toldalék
d. - $(V) n k e ́ n t$ distributivusi toldalék
e. -képpen formalisi
f. $-t$ locativusi

A genitivust mint esetragot szintén kizárja Kiefer (1998), mert azonos a dativus ragjával, így a 25 potenciális főnévi esetragból 18 marad. A 6. táblázatban egy-egy példát hozok az értelmezős szerkezet két tagjának esetegyezésére mind a 18 főnévi esetragot feltüntetve.

6. táblázat: Egyezés az esetragokat tekintve

\begin{tabular}{|l|l|l|}
\hline Az eset neve & Esetrag & Példa \\
\hline 1. nominativus & $\varnothing$ & A kislány, a legszebbik elment a boltba. \\
\hline 2. accusativus & $-\mathrm{t}$ & A házat, a zöldet megveszem. \\
\hline 3. dativus & -nak/-nek & A dolgozónak, a legjobbnak kitüntetés jár. \\
\hline
\end{tabular}




\begin{tabular}{|l|l|l|}
\hline 4. inessivus & -ban/-ben & A kertben, a virágosban sok gyom van. \\
\hline 5. illativus & -ba/-be & A városba, a legközelebbibe járok bevásárolni. \\
\hline 6. elativus & -ból/-böl & A szekrényböl, a régiből vettem ki ezt a ruhát. \\
\hline 7. superessivus & -n/-on/-en/-ön & A problémán, a legújabbon sokat gondolkodtam. \\
\hline 8. delativus & -ról/-röl & Egy utazásról, egy külföldiről álmodozom. \\
\hline 9. sublativus & -ra/-re & Az asztalra, a feketére tedd le a könyvet! \\
\hline 10. adessivus & -nál/-nél & A bátyámnál, a legidősebbnél él a nagymama. \\
\hline 11. ablativus & -tól/-től & A háztól, a szomszédostól ösvény vezet az erdőbe. \\
\hline 12. allativus & -hoz/-hez/-höz & A leveshez, a tegnapihoz nem illik ez a hús. \\
\hline 13. terminativus & -ig & A jóslatig, a sejtelmesig sok időt kellett várni. \\
\hline 14. formativus & -ként & A barátnőmként, a legjobbként velem kell tartanod! \\
\hline 15. translativus & -vá/-vé & Sárkánnyá, ijesztővé változott át hirtelen. \\
\hline 16. instrumentalis & -val/-vel & A késsel, a legélesebbel sem tudtam elvágni a húst. \\
\hline 17. causalis & -ért & Sokat kell dolgozni az eredményért, a kiválóért. \\
\hline $\begin{array}{l}\text { 18. essivus- } \\
\text { formalis }\end{array}$ & -ul/-ül & Péter mintaképül, követendőül szolgál. \\
\hline
\end{tabular}

Az - $U l$ essivus-formalis esetrag alakját tekintve megegyezik az -ul/-ül denominális verbumképzővel (szép - szépül), illetve az -ul/-ül határozórag igen gyakran járul magához a melléknévhez módhatározói funkciót betöltve (rossz - rosszul), és mindez nagymértékben megnehezíti a példakeresést (13). További nehézséget jelent ennél az esetragnál, hogy a vele ellátott főnév általában szorosabb egységet alkot az igével, mintegy idiomatikus kifejezést létrehozva, így maga előtt sem türi meg a melléknevet (14).

(13) a. ?Mari szép mintaképül szolgál. - *Mari mintaképül, szépül szolgál.

b. Péter rossz mintaképül szolgál. - *Péter mintaképül, rosszul szolgál.

(14) a. Nöül vesz. - *Szép nöül vesz.

b. Feleségül megy hozzá. - *Második feleségül megy hozzá.

c. Vendégül lát. - *Hívatlan vendégül lát.

d. Kutyául érzem magam. - *Rühes kutyául érzem magam.

e. Vitézül harcol. - *Jó vitézül harcol. 
A birtokos személyjel előfordulása lehetővé teszi a tárgyrag elmaradását (megetetem a macskám), ezért elvi szinten lehetséges, hogy a tárgyi szerepet betöltő értelmezős szerkezetben csak az értelmezőn jelenjen meg a tárgyrag, miközben a birtokos személyjellel ellátott értelmezett szó nem visel látható accusativusi esetet. A generált adatok azonban kissé erőltetettnek tünnek (15).
a. Hozd magaddal a macskád, a cirmosat!
b. Kinyomtatom a fotóm, a legjobbat.

Összegzésként elmondhatjuk, hogy a hátravetett jelző értelmező mindig ugyanabban az esetben áll, mint az értelmezett szó.

\subsubsection{Egyezés a névutókat tekintve}

A névutókat tekintve is megegyezik az értelmező és az értelmezett szó (16-17). Amint azonban a b) példák mutatják, a szerkezet akkor is grammatikus, ha csak az értelmező után áll névutó (noha ennek van egy feltétele, mégpedig az, hogy az értelmező ne távolodjon el az értelmezett szótól).

(16) a. A virág mellett, a piros mellett találsz egy kártyát.

b. A virág, a piros mellett találsz egy kártyát.

c. A virág mellett találsz egy kártyát, a piros mellett.

(17) a. Az autók alatt, a rosszak alatt a benzin átáztatta a talajt.

b. Az autók, a rosszak alatt a benzin átáztatta a talajt.

c. Az autók alatt a benzin átáztatta a talajt, a rosszak alatt.

Tehát a névutók tekintetében is megfigyelhető az értelmezett szó és a hátravetett jelzői értelmező közötti egyezés.

\subsubsection{Egyezés a jeleket tekintve}

Az értelmezett szónak és az értelmező szerepü melléknévnek kötelező számbelileg is megegyeznie (18). A (18c-e) példák sem kivételek ez alól, ezekben azonban nem alaki, hanem értelmi egyezés történik. 
(18) a. A rózsák, az illatosak gyorsan elfogytak a boltból.

b. *A rózsák, az illatos gyorsan elfogytak/elfogyott a boltból.

c. A sok rózsa, az illatosak gyorsan elfogytak a boltból.

d. Az asszonyok, a legügyesebb és a legokosabb nyerte meg a versenyt.

e. Két asszony, a legügyesebbek nyerték meg a versenyt.

Az -é birtokjelet tekintve is kötelező az értelmezőnek megegyeznie az értelmezett szóval (19). Azt azonban hangsúlyozni kell, hogy ez nem azonos a birtokos jelzőnek megfelelő értelmezővel, amin ugyancsak megjelenik az -é birtokjel (20).

a. A férfié, a magasé ez az autó.

b. *A férfié, a magas ez az autó.

(20) A könyvet, a fiúét visszaadom neked.

Mivel kötelező az értelmezett és az értelmező között a(z értelmi) számbeli egyezés és az -é birtokjellel való egyezés is, így ha mindkét jel jelen van, akkor az egyezés mindkettőt tekintve megfigyelhető (21).

(21) a. A fiúké, a legügyesebbeké az érdem.

b. *A fiúé, a legügyesebbeké az érdem.

c. *A fiúké, a legügyesebbé az érdem.

d. *A fiúké, a legügyesebbek az érdem.

Érdekességként megemlíthető, hogy a birtokos személyjelet tekintve nem történik egyezés a hátravetett jelzői értelmezős szerkezetben (22), sőt az adatokból látható, hogy az esetek többségében rosszul formált mondatokat kapunk. Arra azonban nincs magyarázat, hogy (22d) miért lehetséges, miért válik jól formálttá a példa a birtoktöbbesítő jel megjelenése által.

(22) a. A ruhámat, a szépet veszem fel ma este

b. *A ruhámat, a szépemet veszem fel ma este.

c. *A ruhámat, a legszebbemet veszem fel ma este.

d. A ruháimat, a legszebbjeimet viszem magammal az útra. 
Az -ék asszociatív többesjel esetében nem lehetséges az értelmezett szó és az értelmező közötti teljes alaki egyezés $(23),{ }^{23}$ mivel a vizsgált jel „csak határozott referenciájú főnévi szerkezethez járulhat, vagyis szintaktikailag csak DP kategóriájú főnévi csoporttal egyesíthető” (Bartos 2000a: 698).

a. Kovácsék, a lusták / *a lusta / *a lustáék mindenhonnan elkésnek.

b. Mindenkinek jó véleménye van a barátnőmékröl, *a kedvesekröl / * a kedvesröl / *a kedvesékröl.

A (23a) példából látható, hogy az -ék asszociatív többesjel megjelenésekor kötelező a többes számú egyezés, de maga az asszociatív többesjel már nem tapadhat az értelmező szerepü melléknévhez. A (23b) példa agrammatikusságának szemantikai oka van, csak a barátnőmről állíthatjuk, hogy kedves, és nem a barátnőmék által denotált csoport minden egyes tagjáról. ${ }^{24}$

Összegzésként elmondható, hogy a többes szám jelét (az -ék asszociativ többes jel esetében is) és az -é birtokjelet tekintve jelenik meg kötelezően az egyezés a hátravetett jelzői értelmezős szerkezet tagjai között.

\subsubsection{Egyezés a határozottságot tekintve}

A határozottságot tekintve nem szükséges megegyeznie az értelmezőnek az értelmezett szóval (24-25), továbbá ha az értelmezős szerkezet mindkét tagja határozatlan, eltérhetnek abban, hogy megjelenik-e előttük a határozatlan névelő (26).
a. Egy kenyeret kérek, a legszebbet.
b. Kérek egy kenyeret, a legszebbet.
c. Egy kenyeret, a legszebbet kérem.

\footnotetext{
${ }^{23} \mathrm{Az}$-ék jel funkciója az, hogy entitásokat társít a főnévhez, az ún. fokális referenshez, amelyen megjelenik. A fokális referensek: emberek tulajdonnevei (Kovácsék), emberek rokonsági terminusai (apámék), emberek egyéb köznevei (barátomék). Bartos (2000a) megjegyzi, hogy az -ék jel egy frázisszintü toldalék, vagyis nem szavakhoz, hanem frázisokhoz járul hozzá.

${ }^{24} \mathrm{Az}$-ék jel viselkedését még inkább megvilágítják az alábbi példák (ii-iii), ahol a jelzőként megjelenő melléknév csak a lányomra vonatkozik, és nem a lányomék által denotált csoport minden egyes tagjára. (A lányomék jelentése: a lányom és a hozzá tartozó emberek csoportja.)
}

(ii) Meglátogattak a kisebbik lányomék.

(iii) ?? Meglátogattak a lányomék, a kisebbikek.

Ugyanakkor a lusta Kovácsék (vagyis a személynevek + -ék jel) egy olyan csoportot denotál, amelynek minden tagja Kovács, és emellett lusta. (A Kovácsék jelentése: a Kovács család tagjai, vagyis Kovács 1 , Kovács ${ }_{2}$, Kovács 3 stb.) 
a. Megveszem az autót, egy pirosat.

b. Megveszek egy autót, a pirosat.

(26) a. Veszek egy ruhát, egy pirosat.

b. Veszek egy ruhát, pirosat.

c. Veszek ruhát, egy pirosat.

Az eltérő határozottságú értelmezett szónak és hátravetett jelzői értelmezőnek fontos szerepe lesz a szerkezet elemzésének vizsgálatakor (lásd a 2.5 pont alatti alfejezetet).

\subsection{A hátravetett jelzői értelmező összetevőinek a vizsgálata}

A leíró nyelvtanok nem vizsgálják meg azt a kérdést, hogy vajon bármely elöl álló jelzóböl létre lehet-e hozni értelmezős szerkezetet. Birtokos jelzőből minden esetben létrehozható értelmező, de ugyanez már nem mondható el a minőség- és a mennyiségjelzők esetében. Az alábbiakban példákon keresztül ismertetem, hogy milyen melléknevek és számnevek jelenhetnek meg értelmezőként.

\subsubsection{A szerkezetben megjelenő melléknevek}

Fontosnak tartom kihangsúlyozni, hogy nem minden melléknév töltheti be az értelmezői szerepet (27), első pillantásra úgy tünhet, hogy a nem metszetképző melléknevek nem jelenhetnek meg az értelmezős szerkezetben.

a. Elfogták az állitólagos terroristákat. $\rightarrow$ */??Elfogták a terroristákat, az állitólagosakat.

b. A sajtótájékoztatón megjelent a volt miniszter. $\rightarrow * A$ sajtótájékoztatón megjelent a miniszter, a volt.

A fenti példákkal szemben azonban vannak olyan nem metszetképző melléknevek, amelyek megfelelő kontextusba ágyazva betölthetik az értelmező szerepét: (28a)-ban a miniszterelnök denotációja tartalmaz két alhalmazt, az egyikben a jelenlegi, a másikban az egykori miniszterelnök van. Ehhez hasonlóan (28b)-ben a terroristák denotációja is két alhalmazzal rendelkezik: szembeállíthatjuk egymással az állítólagos és a valódi terroristákat. 
b. Elfogták a terroristákat, az állitólagosakat, míg a valódiakat hagyták elmenekülni.

Mindebből azt a konklúziót vonhatjuk le, hogy ha a nem metszetképző melléknév nem olyan kontextusban fordul elö, amelyben szembeálítható egy másik melléknévvel, akkor nem jelenhet meg hátravetett jelzői értelmezőként.

A felsőfokú melléknevek nem állhatnak névelő nélkül hátravetett jelzői pozícióban (29a), szemben az alapfokú (29b) vagy a középfokú melléknevekkel (29c).
a. Veszek almát, *(a) legpirosabbat. / Veszek egy almát, *(a) legpirosabbat.
b. Veszek almát, pirosat. / Veszek egy almát, pirosat.
c. Majd én veszek almát, pirosabbat. / Majd én veszek egy almát, pirosabbat.

Ez a megszorítás nem az értelmezős szerkezet tulajdonságából vezethető le, hanem a felsőfokú melléknevek szemantikájával van összefüggésben, amelyek mind jelzöi, mind értelmezői funkcióban csak határozott DP-ben jelenhetnek meg (*Veszek egy legpirosabb almát.).

\subsubsection{A szerkezetben megjelenő számnevek}

A számnevek ritkábban jelennek meg értelmezőként, mint a melléknevek. Cs. Nagy Lajos Nyelvtani elemzési gyakorlókönyvében (1991) csak néhány olyan példát találtam, amelyekben az értelmező (sokszor csak értelmezőnek tartott összetevő) egy mennyiségjelzőre vezethetö vissza (30).
a. A nagy höségben ïdítôt sokat megisznak.
b. A beteg kompótot bármennyit ehet.
c. Gombát mennyit szedtetek az erdöben?
d. Kiflit akármennyit vehetsz.
e. Almát többet is ehetsz.

A (30)-as példák hasonlóak abban, hogy a szerkezetben egy kontrasztív topik fordul elö. Ezek a konstrukciók valójában nem tekinthetők értelmezőnek, ezekben egy kvantifikált kifejezés jelenik meg. Az ilyen jellegú példákra még visszatérek a 4.2.1 pont alatt. 
Az adatok alapos vizsgálata után az alábbi megállapításokat tehetjük: A határozott számnév csak a következő esetekben jelenhet meg egy határozott értelmezett szó mellett értelmezőként: ha a számnévi értelmező felveszi a mind előtagot (31b), vagy birtokos személyjelet visel (31c), vagy megkapja az -en végződést (31d). Ez utóbbi csak alanyesetben álló értelmezett szó mellett lehetséges. Határozatlan értelmezett szó után már állhat számnév (31e), de igen gyakori, hogy az is-sel együtt jelenik meg az értelmező (31f).

(31) a. Láttam a három fiút. $\rightarrow$ * Láttam a fiúkat, a hármat / hármat.

b. Láttam a fiúkat, mind a hármat.

c. Láttam a fiúkat, hármójukat.

d. Megérkeztek a fiúk, hárman.

e. Veszek zsemlét, tízet.

f. Láttam gólyát / gólyákat, hármat is.

A sorszámnevek kivétel nélkül betölthetik az értelmező szerepét (32a), azt azonban meg kell jegyezni, hogy elöl álló jelzőként a hagyományos nyelvtanok kijelölő jelzőnek tekintik a sorszámneveket. A törtszámnevek ritkán jelennek meg jelzőként, ugyanígy értelmezői szerepben is ritkán fordulnak elő, de azért akad egy-két példa (32b).
a. Felmásztam az emeletre, az ötödikre.
b. Megettem a maradék tortát, egy negyedet / ?kétharmadot.

Amint a példákból is látható, a számnevek csak korlátozottan - bizonyos feltételek teljesülése esetén - jelenhetnek meg hátravetett jelzői értelmezőként.

\subsection{A görög 'polydefinite' szerkezetek}

Lekakou-Szendrői (2007) olyan görög szerkezeteket vizsgál, amelyekben a melléknévnek van egy saját határozott determinánsa, és ezeket párhuzamba állítják a szoros értelmezővel, N-ellipszist feltételezve. A görögben a szoros értelmezőt (33-34) a következőképpen jellemzi Stavrou (1995): a szerkezetet alkotó mindkét főnévnek van saját determinánsa, felcserélhető a szerkezettagok sorrendje, az értelmező korlátozó értelmü, és csak határozott DP-k állhatnak egymással szoros értelmezői viszonyban. 
a. $o$ aetos to puli

a sas a madár

b. to puli o aetos

a madár a sas

(34) De su ipa oti sinandisa ton Antoniou to filologo, ala

NEG te-GEN mondta-1SG hogy találkozott-1SG az Antoniou a nyelvész de ton Antoniou to mathimatiko.

az Antoniou a matematikus

'Nem azt mondtam neked, hogy Antoniou-val a nyelvésszel találkoztam, hanem hogy Antoniou-val a matematikussal.'

Azok a görög 'polydefinite’ szerkezetek (35a), amelyekben a melléknév a második szerkezettag, első ránézésre igen nagy hasonlóságot mutatnak a magyar hátravetett jelzői értelmezőkkel.
a. to spiti to megalo
a ház a nagy
b. to megalo to spiti
a nagy a ház

[görög]

A szerkezet jellemzői között Lekakou-Szendrői (2007) a következőket sorolják fel:

a) A konstrukciót szabad szórend jellemzi, amelynek azonban az a feltétele, hogy a melléknév előtt is szerepelnie kell a határozott determinánsnak (35).

b) A nem metszetképző melléknevek nem jelenhetnek meg ebben a konstrukcióban (36).

c) Pragmatikailag korlátozónak kell lennie a melléknévnek, ez a feltétel azonban nem teljesül a (37)-es példában, hiszen minden kobra mérgező a világtudásunk alapján.

\begin{tabular}{|c|c|c|c|c|}
\hline \# Idame & tis & dilitiriodis & tis & kobres. \\
\hline láttam & a-PL.ACC & mérgező-PL.ACC & a-PL.ACC & kobra-PL.ACC \\
\hline
\end{tabular}


d) Határozatlan determinánssal nem jelenhet meg a szerkezet (38).

$$
\begin{aligned}
& \text { ena megalo (*ena) spiti } \\
& \text { 'egy nagy (*egy) ház’ }
\end{aligned}
$$

e) A két DP egy összetevőt alkot, amire bizonyítékként azt hozza fel a szerzőpáros, hogy osztoznak az eseten, és egy prepozíció előzi meg őket (39).

$$
\begin{aligned}
& \text { [PP P me [KP K [DP [DP to kokino] [DP to podhilato]]] } \\
& \text { INSTR a-ACC piros-ACC a-ACC kerékpár-ACC }
\end{aligned}
$$

'a kerékpárral, a pirossal'

Lekakou-Szendrői (2007) amellett érvelnek, hogy a görög 'polydefinite' szerkezeteket két DP alkotja, csak az egyikböl töröljük a fönevet (40).
a. [DP [DP to megalo Ø] [DP to spiti]]

$$
\text { a nagy a ház }
$$

b. [DP [DP to spiti] [DP to megalo Ø]]

$$
\text { a ház a nagy }
$$

A görög szerkezet szoros értelmezőként való elemzését a következő tényezők támasztják alá:

a) A szoros értelmezőre jellemző szórendi szabadság (bármelyik elem állhat elöl) a görög szerkezetre (35) is érvényes. Az utóbbinál egyetlen feltétel: a szerkezet mindkét része elött meg kell jelennie egy-egy határozott determinánsnak.

b) A szerkezet szoros értelmezőként való elemzése megmagyarázza, miért nincsenek ún. 'polyindefinite' szerkezetek (38), hiszen a szoros értelmező szükségszerüen maga után vonja a két határozott DP-t.

c) A szoros értelmezőben korlátozó viszony van a két alrész között: a valódi alhalmaz kényszere szerint a szoros értelmezőben követelmény, hogy az egyik DP denotációja valódi alhalmaza legyen a másik DP denotációjának. Mint már láttuk, a görög 'polydefinite' szerkezetekben sem jelenhet meg olyan melléknév, amely pragmatikailag nem korlátozó (38).

Kolliakou (2004) alkalmaz egy tesztet, hogy megmutassa, a 'polydefinite' szerkezetek korlátozottabb kontextusban vannak használva, mint a monadikus párjuk. Míg az a szerkezet, amely csak egy határozott determinánst tartalmaz (41), mind a négy kontextussal (43a-d) el- 
képzelhető, addig a 'polydefinite' szerkezet (42) csak a (43a, b) forgatókönyvekkel konzisztens.

(41) O Yannis taise ta zoa. I mikres gates itan pinasmenes.

'Yannis állatokat tart. A fiatal macskák éhesek voltak.'

(42) O Yannis taise ta zoa. I mikres i gates itan pinasmenes.

'Yannis állatokat tart. A macskák, a fiatalok éhesek voltak.'

(43) a. A Yannis által tartott összes állat macska volt, és voltak fiatal és nem fiatal macskák is közöttük.

b. Yannis macskákat és más állatokat is tartott, és voltak fiatal és nem fiatal macskák is közöttük.

c. A Yannis által tartott összes állat macska volt, és csak fiatal macskák voltak közöttük.

d. Yannis macskákat és más állatokat is tartott, és minden macska fiatal volt.

Ha a görög 'polydefinite' szerkezeteket összevetjük a magyar hátravetett jelzői értelmezővel, akkor a következő hasonlóságokat és különbségeket emelhetjük ki:

a) Az értelmezett szónak meg kell elöznie az értelmezőt a magyar szerkezetben (44).

(44) a. a ház, a nagy

b. *a nagy, a ház

b) A magyarban a nem metszetképző melléknevek (45a) is megjelenhetnek értelmezőként, ami azonban feltételekhez van kötve, amint a 2.3.1 pont alatt láthattuk (45b).

(45) a. A miniszter, a hajdani kezet fogott a jelenlegivel.

b. * Elfogták a terroristákat, az állítólagosakat.

c. Elfogták az állítólagos terroristákat.

c) A melléknév pragmatikailag korlátozónak tűnik a magyar hátravetett jelzői értelmezős szerkezetekben. A (46)-os példa csak egy olyan világban képzelhető el, ahol engedélyezett a poligámia.

A férjem, a lusta semmilyen házi munkára sem hajlandó. 
Mint már korábban láthattuk a 2.1 pont alatti alfejezetben, Kolliakou (2004) tesztje - a magyar hátravetett jelzői értelmezőre alkalmazva - a szerkezet korlátozó volta mellett szól.

d) Határozatlan determinánssal is megjelenhet a két főnévi csoport (47a), sőt a szerkezettagok eltérő határozottságúak is lehetnek (47b).
a. Veszek egy szoknyát, egy feketét.
b. Megveszek egy szoknyát, a feketét.

e) A magyar hátravetett jelzői értelmező esetében nem lehet azt állítani, hogy a két szerkezettag egy összetevőt alkot. Noha ugyanaz az esetrag jelenik meg az értelmezett szón és az értelmezőn is, illetve osztozhatnak ugyanazon a névutón (amint ezt a 2.2.1 és a 2.2.2 pont alatti részek mutatják), de a két szerkezettag nem alkot egyetlen intonációs egységet, valamint nem kötelező a szomszédosságuk (48).

Egy csizmát vettem, egy pirosat a legjobb barátnőmnek.

Az összehasonlítás eredménye azt mutatja, hogy bár első pillantásra hasonlónak tűnhet a magyar hátravetett jelzői értelmező a görög 'polydefinite' szerkezethez, valójában több az eltérés, mint a hasonlóság.

Ha a magyar hátravetett jelzői értelmező helyét keressük az értelmező fajtáin belül, kizárhatjuk a szoros appozíciót, amelynek a kritériumai nem teljesülnek a hátravetett jelzői értelmezőt tartalmazó példákban. Ugyanakkor a laza appozíció alá sem sorolhatjuk be a hátravetett jelzői értelmezőt, mivel az előbbi nem korlátozó, míg az utóbbi korlátozó.

Ez egy újabb érv amellett, hogy a magyarban a hátravetett jelzői és az azonosító értelmezőt egymástól elkülönítve vizsgáljuk, és hogy ne egy egységes szerkezetet akarjunk a két konstrukcióhoz rendelni, ahogyan a hagyományos nyelvtanok tették eddig.

\subsection{A hátravetett jelzői értelmező szerkezete}

Ebben az alfejezetben sorra veszem a hátravetett jelzői értelmező korábbi elemzéseivel szembeni ellenérveket, majd bemutatom az általam javasolt elemzési eljárást, amelynek a középpontjában az ellipszis áll. Fontosnak tartom megvizsgálni, hogy az értelmezős szerkezet ellipszisként való felfogása nem sérti-e meg az elliptálás feltételeit, így azok ismertetésére is nagy gondot fordítok. 


\subsubsection{Ellenérvek a korábbi elemzésekkel szemben}

Ebben a részben a szakirodalomban fellelhető érveket, ellenérveket már nem fogom megismételni (lásd 1.1.3.2 pont alatti alfejezetet), csak a saját ellenérveimet fogom ismertetni.

Ha alárendelést feltételezünk a hátravetett jelzői értelmezős szerkezetben, akkor eltérő határozottságú értelmezett szó és értelmező esetén az lenne az elvárásunk, hogy a fej, vagyis a tárgyi argumentumként megjelenő értelmezett szó irányítja az állítmánnyal való határozottsági egyeztetést. Egyes példák azonban azt mutatják, hogy ez nem feltétlenül van így (49).

\section{(49) Egy kenyeret, a legszebbet kérem.}

A (49)-es példában azt látjuk, hogy a határozottságot tekintve az állítmányt nem az értelmezett szóval, hanem az értelmezővel kell egyeztetni. Ha azonban ellipszisként ${ }^{25}$ elemezzük ezeket a szerkezeteket, máris magyarázatot kapunk arra, hogyan történhet ez az egyeztetés (50).

Egy kenyeret [kérek], a legszebb [kenyer]-et kérem.

Az értelmezős szerkezet alárendelésként való elemzése elleni érv azonban még nem cáfolja azt a megoldást, hogy két fönévi csoport mellérendelése történik, és a közelségi elv (Quirk et al 1985) ${ }^{26}$ alapján megy végbe a határozottsági egyeztetés a tárgy és az ige között. A következő két érv azonban az NP-koordináció ellen szól: É. Kiss (2012) a koordinált NP-ket vizsgálva (51a) esetében ellipszist feltételez, míg (51b) esetében NP-koordináció történik az egyeztetés alakulása miatt. Ha ezzel a kétféle szerkezettel összehasonlítjuk az értelmezős konstrukciót (51c), akkor látható, hogy az az (51a)-hoz hasonlóan viselkedik az egyeztetést tekintve.
a. Végre megegyezett a két lány és [†égre megegyeztek] a fiúk.
b. Végre megegyeztek [a két lány és a fiúk].
c. Végre megegyezett a két lány, a legokosabbak.

\footnotetext{
${ }^{25}$ Az ellipszis alá eső szerkezeti elemeket áthúzással jelölöm.

${ }^{26}$ A közelségi elv (Principle of Proximity) azt jelenti, hogy az igével való egyeztetés során a posztverbális pozícióban megjelenő DP-koordinációnak az első tagjával, míg a preverbális pozícióban megjelenő DPmellérendelésnek a második tagjával egyeztetjük az igét.
} 
A másik ellenérvem az, hogy az értelmezőnek nem kell közvetlenül az értelmezett szó után állnia, más összetevők is megjelenhetnek közöttük (52), és ekkor azért nem beszélhetünk NPkoordinációról, mert az úgynevezett mellérendelő szerkezeti megszorítás (Coordinate Sructure Constraint) elve szerint (Ross 1967: 98-99) nem lehet egy mellérendelői szerkezetből kimozgatni az egyik tagot, vagy annak valamely elemét. Két tagmondat mellérendelése és az azokon végrehajtott ellipszis azonban az ilyen példákban is egy lehetséges elemzési módnak tünik.

(52) A húgom látogatott meg, a legfiatalabb [húgom] [tátogatot meg] tegnap este a kórházban.

További érvként szolgálhat az ellipszises elemzés mellett, hogy N(P)-ellipszis során a birtokjel, illetve a birtokos személyjelek is törlődnek (53a), hasonlóan a hátravetett jelzőkhöz (53b), ahogyan ezt a 2.2.3 pont alatti alfejezetben láttuk a (22)-es példákban.
a. *Te a csúnya ruhádat veszed fel ma este, én a szépemet.
b. *A ruhámat, a szépemet veszem fel ma este.

Bár látszólag Jakab $(1977,1978)$ redukciós ${ }^{27}$ elképzelése nagyon hasonló a fentiekben vázolt elliptikus elemzéshez, de a két felfogás között fontos különbségek vannak. Jakab nem vizsgálja meg a hátravetett jelzői értelmezős szerkezetnek az igével való egyeztetését, és az általa alkalmazott redukciós elv önmagában nem magyarázza meg a (49)-es példát, amelynek elemzését a közelségi elv müködésének feltételezésével kell kiegészíteni. A redukciós elv azzal jár, hogy a redukált „tag (megváltozott mivoltában) egy szinttel feljebb kerül, vagyis nem másodrendü, hanem elsőrendü bővítmény lesz" (Jakab 1977: 42). Mindez a generatív elméleti keretben ahhoz vezetne, hogy a redukált szerkezet melléknevének a DP-ben a főnévi fej helyén kellene megjelennie, amely azonban teljesen kizárt ebben a megközelítésben. A szófajváltást - amely mellett Jakab $(1972,1977)$ érvel - nem támasztják alá sem morfológiai, sem szintaktikai érvek. Az értelmezői szerepủ melléknév továbbra is a melléknévre, és nem a

\footnotetext{
${ }^{27}$ Jakab (1972: 45) a következö módon fogalmazza meg a redukció törvényét: „Ha a jelzös szószerkezet alaptagja odaértés vagy más ok folytán hiányzik a mondatból, a jelző vagy az alárendelő összetett mondat fömondatának jelzői helyzetủ utalószava mint alárendelt tag alkalmilag átveszi a jelzős szerkezet jelentését, továbbá az alaptag szófaji értékét, alaki kitevőit (a redukálódott birtokos jelzős szerkezetet -é birtokjel jelzi) és mondatbeli funkcióját".
} 
fönévre jellemző elöhangzós szuffixumot veszi fel (54a); valamint a melléknévnek továbbra is csak rá jellemző módosítói lehetnek $(54 b, c)$.
a. a kabátokról, a havasakról / *havasokról
b. *Véget vetettünk a vitának, a kirándulásról szóló hevesnek.
c. Sokáig beszéltek a vitáról, a kissé hevesröl.

Az átmeneti szerkezet feltételezése nem oldja meg azt a kérdést, hogy milyen struktúrát rendelhetünk az értelmezöt tartalmazó konstrukcióhoz, ennélfogva a példák elemzése során felmerülő problémákra sem képes kielégítő magyarázatot adni.

Az azonosító/értelmezői viszony szintén nem ad támpontot a szerkezeti elemzéshez, ráadásul a redukciós elvre épül, amely - mint láthattuk - a generatív elméleti keretbe átültetve rossz jóslatokhoz vezet.

\subsubsection{A hátravetett jelzői értelmező elemzése ellipszisként}

Amint az előző pontból is kiderül, az elemzési javaslatom a hátravetett jelzői értelmező esetében az, hogy a szerkezet két tagmondat koordinációja és az azokon végrehajtott ellipszis által jön létre. Az értelmezős szerkezetek elemzésének bemutatása előtt röviden ismertetem az ellipszis jellemzőit, fajtáit és feltételeit, külön kitérve arra a kérdésre, hogy az értelmező ellipszisként való felfogása nem sérti-e meg ezeket a feltételeket. Ezt követően sorra veszem azokat az ellipszisfajtákat, amelyek megjelenésével számolnunk kell a magyar hátravetett jelzői értelmezős szerkezetekben. Végül bemutatom a vizsgált példákat - minden lehetséges szórendet figyelembe véve, és elvégzem az ismertetett példamondatok szerkezeti elemzését.

Fontos megjegyezni, hogy ha a hátravetett jelzői értelmezőt ellipszisként elemezzük, nem beszélhetünk az értelmezett szó és az értelmező közötti egyeztetésről, hanem azok ugyanazt a jegytartalmat viselik az esetet és a számot tekintve. ${ }^{28}$

\subsubsection{Az ellipszis jellemzői}

Az ellipszis „meghatározott lexikai egységek hangalakjának a be nem illesztése a tagmondat szerkezetének egyes pozícióiba”"29 (Bánréti 2007: 79). Ha az engedélyező tagmondat megelőzi

\footnotetext{
${ }^{28}$ Ez abból következik, hogy a kontextus-azonosság feltételével összhangban ugyanabban a grammatikai függőségi viszonyban áll az értelmezett és az értelmező is a saját tagmondatán belül.
} 
az ellipszist tartalmazó tagmondatot, akkor elöreható ellipszisröl beszélünk, ha követi, akkor pedig visszaható ${ }^{30}$ ellipszisnek nevezzük.

Ezen a ponton érdemes rámutatni arra, hogy a Jakab-féle redukciós törvény nem ugyanazt jelenti, mint az ellipszis Wilder (1997), Bartos (2000b), Merchant (2004, 2010, 2013), Bánréti (2007) alapján. Az ellipszis során nem történik szófajváltás, az értelmező szerepủ melléknév nem veszi át az elliptált főnév szerkezeti helyét. Ennek alapján kijelenthetjük, hogy az általam képviselt elemzés csak látszólag, első pillantásra hasonlít Jakab $(1977,1978)$ nézetéhez, valójában azzal szöges ellentétben áll.

A következőkben csak az ellipszis feltételeit fogom ismertetni Wilder (1997) és Bánréti (2007) alapján, mivel nem tartom a disszertáció feladatának a szakirodalomban felmerülő problémák ismertetését. ${ }^{31}$

\subsection{Az előreható ellipszis feltételei}

a) A tartalom-azonosság feltételét Wilder (1997: 73) úgy határozza meg, hogy ha az engedélyező és az ellipszis alá eső rész tartalma azonos, akkor mehet végbe az ellipszis. Előreható ellipszis esetén nem kötelező a teljes hangalaki azonosság (55).

(55) John drinks wine and his kids [drink] cola.

'John bort iszik, és a gyerekei kólát [isznak].'

Wilder (1997)-hez hasonlóan az előreható ellipszis esetében Bánréti (2007) a morfoszintaktikai feltételeket - Bartos (2000b) nyomán - úgy határozza meg, hogy nem szükséges az ellipszis alá eső rész és az antecedens teljes alaki egyezése (például VP-ellipszis ese-

\footnotetext{
${ }^{29}$ Wilder (1997) szerint elöreható ellipszis esetében történik a hangalakok be nem illesztése, míg visszaható ellipszis során a már beillesztett hanganyag utólagos törlésével kell számolni.

30 Bánréti (2007) a hátraható ellipszis elnevezést használja, de mivel az angol 'backward' kifejezés visszahatóként való fordítása pontosabban utal az adott ellipszisre, én az utóbbit követem az elemzések során.

${ }^{31} \mathrm{Az}$ ellipszissel foglalkozó gazdag szakirodalom ismerete elengedhetetlen ahhoz, hogy a hátravetett jelzői értelmező szerkezeti elemzése során építeni lehessen a különféle ellipszisfajtákra. A teljesség igénye nélkül megemlítek néhány problémát, amellyel a szakirodalom feldolgozása során szembesültem:

1) A szintaktikai és a szemantikai azonosság kérdésköre (Baltin 2014, Merchant 2014, Johnson 2014).

2) Az elliptálás folyamatát tekintve az előreható és a visszaható ellipszis különbözik egymástól (Wilder 1997, lásd a 29-es lábjegyzetet).

3) Bánréti (2007) által tárgyalt egyes ellipszisfajták a magyarban valójában ugyanazt a jelenséget fedik le, az irtóhangsúlyos összetevő után megjelenő előreható ellipszisen belül az általa megkülönböztetett V-, VP-, mondat-, NP- és AdvP-ellipszis ugyanazt a mechanizmust mutatják: a fókusz után törlünk minden összetevőt.
} 
tén csak az idő-/módjelnek kell azonosnak lennie, az alany és a tárgy személyével/számával/határozottságával való egyeztetést jelölő Agr-jegyeknek nem). ${ }^{32}$

$$
\text { *János ma teszi le a vizsgát, Péter meg tegnap [teszi le a vizsgát]. }
$$

b) A kontextus-azonosság feltételét Wilder (1997: 98) úgy határozza meg, hogy az elliptált rész antecedense ugyanabban a hierarchikus viszonyban áll a tagmondatával, mint az elliptált rész a saját tagmondatával (57).

a. Mary claimed that Paul hit Sue and [Mary claimed that Paul] ran away.

'Mary azt állította, hogy Paul megütötte Sue-t, és [Mary azt állította, hogy Paul] elfutott.'

b. Mary claimed that Paul hit Sue and [Mary] ran away.

'Mary azt állította, hogy Paul megütötte Sue-t, és [Mary] elfutott.'

Bánréti (2007) amellett érvel, hogy a megelőzés és a szerkezeti dominancia feltétele szerint az engedélyező tagmondatban lévő antecedensnek k-vezérelnie kell az ellipszis alá eső részt (58).

a. Az elsősök MONDATTANBÓL akarnak elöször vizsgázni, a másodikosok azt mondják, hogy ők inkább ALAKTANBÓL [akarnak elöször vizsgázni]].

b. *A másodikosok azt mondják, hogy ők ALAKTANBÓL akarnak elöször vizsgázni, az elsősök meg inkább MONDATTANBÓL [akarnak elöször vizsgázni]]. ${ }^{33}$

\footnotetext{
${ }^{32}$ Az alábbi példa (iv) kapcsán felmerült az a kérdés, hogy mi zárja ki annak lehetőségét, hogy az elliptált rész jelen idejü legyen.

(iv) János tegnap tette le a vizsgát, Péter meg ma [tettele] / * [teszi le].

Véleményem szerint a jelen idejű alakot nem elliptálhatjuk a szerkezetből. Ezt igazolja az a tény, hogy ha a második tagmondatba beillesztünk egy olyan elemet, amely mellett nem jelenhet meg a múlt idejü igealak, akkor a mondat rosszul formált lesz ellipszissel (v).

(v) *János tegnap tette le a vizsgát, Péter meg ma ezután.

${ }^{33}$ Bánréti (2007) példáiban a * nem feltétlenül a mondat rosszul formáltságát jelenti, hanem azt, hogy az adott példában feltüntetett ellipszis nem lehetséges. Ez a megállapítás az általam idézett példák közül a (58b)-re és a (61b)-re érvényes.
} 
Ha az engedélyező tagmondat és az ellipszist tartalmazó tagmondat is egy-egy főmondatnak van alárendelve, akkor a releváns tagmondatoknak párhuzamos szerkezetủeknek kell lenniük, s ez esetben nem kell teljesülnie a k-vezérlésnek (59).

(59) A másodikosok azt mondják, hogy ök ALAKTANBÓL akarnak elöször vizsgázni, az elsösök meg azt mondják, hogy ök inkább MONDATTANBÓL [a vizsgázni].

c) A lokalitási feltételről Wilder (1997: 65) azt állítja, hogy egy elliptált részt csak olyan antecedenssel lehet azonosítani, amely a legközelebbi mellérendelt tagmondatban van (60).

$$
\text { John came in and Mary sat down and [Mary/*Jehn] read a book. }
$$
'John bejött, és Mary leült, és [Mary /*John] olvasott egy könyvet.'

A szomszédosság feltételéről előreható ellipszis esetén - Wilder (1997)-tel ellentétben Bánréti (2007) azt állítja, hogy nem szükséges, hogy az antecedens és az ellipszis alá eső rész szomszédos tagmondatban legyen (61a). Ha azonban a közbeékelt tagmondat tartalmaz egy potenciális antecedenst, akkor az ellipszis rosszul formált lesz (61b).

(61) a. A nagymama az UNOKÁJÁTÓL akart segítséget kérni, ugyanis az árvíz már a ház felé közeledett, a nagypapa meg a LÁNYÁTÓL [akart segítséget kérni].

b. *A nagymama az UNOKÁJÁTÓL akart segítséget kérni, ugyanis a szomszédok a TÜZOLTÓKTÓL kaptak mentőcsónakot, a nagypapa meg a LÁNYÁTÓL??[akart se gítséget kérni] /?? [kapott mentöesónakot].

Az elöreható VP-ellipszis esetén lehetséges a nem párhuzamos mondatszerkezet (62).

(62) JÁNOS érkezett meg valahova, mégpedig a DÉLI PÁLYAUDVARRA [érkezett meg]. 


\subsection{A visszaható ellipszis feltételei}

a) A visszaható ellipszis esetében a tartalom-azonosság feltétele Wilder (1997: 90) szerint azt jelenti, hogy az engedélyező és az ellipszis alá eső részek fonológiai formájának teljesen azonosnak kell lennie (63).

(63) John said that I [tove / toved] and Mary said that we love/ she loved/* she loves jazz.

'John azt mondta, hogy én [szeretem /szerettem], míg Mary azt mondta, hogy mi szeretjük / ö szerette / ő szereti a jazzt.'

Fontos megjegyezni, hogy a magyarban ez a megszorítás nem igaz a visszaható ellipszis során (64). Az előreható ellipszishez hasonló morfoszintaktikai feltételek teljesülnek, vagyis szükséges az engedélyező ige és az ellipszis alá eső ige tövének és időjelének azonossága, de nem szükséges az Agr-végződések megegyezése.

(64) Mi a kacsát [f" ti meg a csirkét fözitek meg.

b) A kontextus-azonosság feltétele Wilder (1997: 97) szerint azt jelenti, hogy az antecedensnek a tartományához való viszonya azonos az elliptált résznek a tartományához való viszonyával. Az előreható ellipszissel ellentétben itt akkor is lehetséges az ellipszis, ha egy mélyebben beágyazott tagmondatban van az antecedens (65).

(65) Mary can run [_], and I believe that John can run 5000 metres in 30 minutes.

'Mary le tud futni [_], és úgy hiszem, hogy John is le tud futni 5000 métert 30 percen belül.'

Bánréti (2007) a magyar példákkal azt illusztrálja, hogy a tagmondatok szerkezete kötelezően párhuzamos (66). ${ }^{34}$

(66) JANCSI \# \# [adott ajándékot Juliskának], meg ÉN adtam ajándékot Juliskának.

\footnotetext{
${ }^{34}$ A \# \# olyan szünetet jelöl, amely előtt kiemelkedő intonáció van (Bánréti 2007: 98).
} 
c) A lokalitási feltételről Wilder (1997) azt állítja, hogy a visszaható ellipszis esetében ugyanúgy müködik, mint az előreható ellipszisnél.

Bánréti (2007) a visszaható ellipszis kapcsán szintén amellett érvel, hogy az ellipszist tartalmazó tagmondatnak közvetlenül meg kell előznie az engedélyező tagmondatot, a két tagmondatnak szomszédosnak kell lennie (67).

(67) *A nagymama az UNOKÁJÁTÓL [akart segítséget kérni], ugyanis az árvíz már a ház felé közeledett, a nagypapa meg a LÁNYÁTÓL akart segítséget kérni.

d) Az ellipszist közvetlenül balról határoló egység lehet nem teljes frázis (68).

$$
\text { Ödön PÉNZ [nélküll vásárolt], Jani meg FEDEZET nélkül vásárolt. }
$$

2.5.2.1.3 Az ellipszis feltételei a hátravetett jelzői értelmezős szerkezetben A következő példákon (69) keresztül fogom szemléltetni, hogyan teljesülnek az ellipszis feltételei a hátravetett jelzői értelmezős szerkezet ellipszisként való elemzése során.

a. A rózsák [elfogytak a boltbót], az illatos [fózsá]-ak elfogytak a boltból.

b. Elfogytak a boltból a rózsák, az illatos [rózsá]-ak [fogytak el a boltbót].

c. Sok rózsa [nyílik a kertben], piros [rózsá]-ak nyílnak a kertben.

d. Egy kenyeret [kérek], a legszebb [kenyer]-et kérem.

e. A csizmám [nélküll nem megyek sehova], a piros [esizmám] nélkül nem megyek sehova.

f. A lányomtól [telet kaptan], a legokosabb [tányem]-tól /* a legokosabb [tá nyom]-nak levelet kaptam.

g. Ma a rózsát [veszem meg], holnap a két liliomot [veszem meg], a piros [tiliөm]-akat / *a piros [rózsá]-at veszem meg.

h. Ma veszem meg a rózsát, ugyanis holnap nem érek rá. A pirosat.

A tartalom-azonosság feltétele teljesül a fenti példákban mind az előreható, mind a visszaható ellipszis esetében, de amint a (69c, d) mutatja, Bartos (2000b) és Bánréti (2007) alapján a visszaható ellipszisnél is megengedettek az eltérő Agr-végződések, szemben Wilder (1997) megszorításával. 
(69e) arra példa, hogy a visszaható ellipszis esetében a közvetlenül határoló kategória lehet nem teljes frázis is.

(69f) azt példázza - ahogyan egyébként a többi adat is bizonyítja -, hogy a kontextusazonosság feltétele sem sérülhet.

Különösen érdekes a szomszédosság feltételének vizsgálata, hiszen ezen a ponton is eltérés mutatkozik a Wilder (1997) és Bánréti (2007) által felállított feltételek között. A (69g) példa azt mutatja, hogy az értelmezett szónak és az értelmezőnek egymással szomszédos tagmondatokban kell megjelenniük, vagyis az ellipszist az a potenciális antecedens engedélyezi, amely az elliptált részt tartalmazó tagmondattal szomszédos tagmondatban található. $(69 \mathrm{~g})$ esetében azt is gondolhatnánk, hogy a közbeékelődő potenciális antecedens (liliom) gátolja a távolabbi antecedens (rózsa) elérését, de (69h) cáfolja, hogy csupán ez lenne az ok. (69h)-ban az értelmező már nem szerves része a mondatnak, hanem inkább csak egy utógondolat. Ezen szerkezetek azonban kívül esnek jelen dolgozat vizsgálódási körén.

\subsubsection{Az ellipszis fajtái a magyar értelmezős szerkezetekben}

Az alábbiakban látni fogjuk, hogy a következő ellipszisekre, mozgatásokra találhatunk példát a magyar értelmezős szerkezetekben. ${ }^{35}$ A különféle ellipszisfajtákat a hátravetett jelzői értelmezős szerkezettől független példákkal szemléltetem.

1. Az N-fej ellipszise: Előreható ellipszissel elliptáljuk az N-fejet, amelynek az eset- és számjegyei a melléknéven fognak megjelenni (70). Mivel a szám és az eset is frázishoz járul, az Nfej törlése ezeket a toldalékmorfémákat nem érinti, azok ott maradnak a frázisvégeken, és az ellipszis után megmaradt tartomány jobb szélén kiejtett elemhez (jelen esetben a jelzői szerepü melléknevekhez) fognak morfológiailag tapadni. Ez a fajta ellipszis minden hátravetett jelzői értelmezős szerkezet esetében megtörténik, és mindig csak a második tagmondatban lehetséges, hiszen az értelmezőnek követnie kell az értelmezett szót.

$$
\text { Te az olcsó autót vetted meg, én meg a drága [auté]-t vettem meg. }
$$

2. Zsilipelés (sluicing): A fókuszos összetevő után minden más összetevőt elliptálunk a második tagmondatból. Craenenbroeck-Lipták (2006) - Merchant (2001, 2004) elképzelését kiterjesztve - amellett érvelnek, hogy a magyar zsilipelés minden olyan szintaktikai környezetben

\footnotetext{
${ }^{35}$ Vannak további ellipszisfajták - mint például a hántolás (stripping) vagy az ürképző ellipszis (gapping) -, amelyekre nem tudtam támaszkodni a hátravetett jelzői értelmező szerkezeti elemzése során.
} 
megjelenhet, ahol egy operátor/változó függőség van, vagyis nemcsak az összetevős kérdésekben (71a), hanem a kijelentő mondatokban is, hátul hagyva egy fókuszált (71b) vagy disztributív kvantifikációs egységet (71c).

(71) a. János meghívott valakit, de nem tudom, hogy KIT [e].

b. János meghívott valakit és azt hiszem, hogy BÉLÁT [e].

c. Tudtam, hogy János meghívott néhány embert, de nem tudtam, hogy mindenkit [e].

3. Visszaható ellipszis: Az első tagmondatból elliptálhatjuk az igét (72a) - olykor egy-egy argumentumával együtt (72b) - vagy egy főnévi csoportot (72c), vagy az igével együtt egy nem teljes szószerkezetet is $(72 \mathrm{~d})$.
a. Ö egy autót [ mi pedig egy lakást vettünk.
b. Mi Pécsett [veszünk lakást], ti pedig Pesten vesztek lakást.
c. Mi felújítottuk [a lakást], ök meg berendezték a lakást.
d. Mi esernyö [nélküll indultunk útnak], Jánosék pedig pénz nélkül indultak útnak.

4. ATB (across-the-board) mozgatás: Minden koordinált tagmondatból balra kimozgatva kiemeljük ugyanazt az összetevőt, amely nyomot hagy az eredeti helyein (Munn 1998), amint ezt a (73)-as példa mutatja.

(73) Who $o_{i}$ did you say that Carrie likes $e_{i}$ and Sarah hates $e_{i}$ ? [angol]

'Kit ${ }_{i}$ mondtál, hogy Carrie szereti e és Sarah gyülöli $e_{i}$ ?'

5. RNR (Right Node Raising): A jobb csomópontra emelés során minden koordinált tagmondatból jobbra kimozgatva kiemeljük ugyanazt az összetevőt (Larson 2012: 143), ahogyan ez (74)-ban látható.

(74) Mary bought $e_{i}$, and John read $e_{i}$, the newspaper . $_{\text {. }}$

'Mary megvette $\mathrm{e}_{\mathrm{i}}$, John elolvasta $\mathrm{e}_{\mathrm{i}}$ az újságot ${ }_{\mathrm{i}}$ '

Fontos kihangsúlyozni, hogy fókuszhangsúlyos összetevő nem elliptálható, mivel az ellipszis egyik fő feltétele, hogy a törölt résznek visszanyerhetőnek, visszakereshetőnek kell 
lennie (Wilder 1997: 72), de az ellipszis során „elnémított” részt megfosztjuk a hangsúlyától, vagyis ezáltal értékes információt veszítenénk a fókusz törlésekor. Ebből adódóan a hátravetett jelzői értelmezős szerkezeteknek két tagmondat koordinációjaként és az azokon elvégzett ellipszisként való elemzése során a következő ellipszisfajtákra és mozgatásokra szükséges támaszkodni: N-fej ellipszise, zsilipelés, visszaható ellipszis (VE), ATB, RNR.

\subsubsection{A vizsgált példák}

Az alábbi példákkal kell számolnunk az elemzés során, összegyüjtve az összes szórendi változatát egy olyan mondatnak, amely hátravetett jelzői értelmezőt tartalmaz: ${ }^{36}$

1. Mari megette az almát, a ZÖLDET.

2. Mari az almát, a zöldet MEGette.

3. Az almát, a zöldet megette Mari.

4. Az almát, a zöldet Mari MEGette.

5. Megette Mari az almát, a ZÖLDET.

6. Megette az almát, a zöldet Mari.

7. MARI ette meg az almát, a ZÖLDET.

8. Az almát, a zöldet MARI ette meg.

9. Az ALMÁT, a ZÖLDET ette meg Mari.

10. Mari az ALMÁT, a ZÖLDET ette meg.

\subsubsection{Elemzések}

Amint azt már előrebocsátottam, az N-fej előreható ellipszise minden szerkezetben megtörténik, hiszen ily módon elliptálható az értelmező mögül a redundáns elem (vagyis az értelmezett szó ismétlődő hangalakja). Ezzel kombinálódik a többi ellipszisfajta, illetve mozgatás, így ötféle szerkezettel kell számolnunk. Az alábbiakban ismertetem az ötféle elemzést, megtartva a példamondatok eredeti sorszámát. A szerkezetekben azt is feltüntetem, hogy melyik ellipszisfajta hol érvényesül. A *-gal jelölt elemzés azért nem járható út, mert hangsúlyos összetevőt nem elliptálhatunk, a visszakereshetőségi feltétel miatt nem lehet egy elemet úgy törölni, hogy az információvesztéssel járjon, márpedig a hangsúly - elnémítás után - nem kereshető vissza.

\footnotetext{
${ }^{36}$ A példamondatokban a hangsúlyos részeket NAGYBETÜVEL jelöltem.
} 


\section{Az N-fej ellipszise és visszaható ellipszis (VE)}

Az első tagmondatból visszaható ellipszissel törölni kell az értelmezett szó utáni részt, míg a második tagmondatban az értelmezőn belül az $\mathrm{N}$-fej elliptálása történik. A második tagmondatban azért lehetséges a fókuszhangsúlyos $\mathrm{N}$-fej törlése, mert a fókuszhangsúlyra vonatkozó információt tovább viszi a DP maradéka (a melléknév és az esetrag). Két szórendi változat elemezhető ezzel a két ellipszisfajtával.

3. Az almát, a zöldet megette Mari.

Az almát [megette Mari], a zöld [almá]-t megette Mari.

$$
\text { VE } \quad \text { N-fej ellipszise }
$$

9. Az ALMÁT, a ZÖLDET ette meg Mari.

Az ALMÁT [ette meg Mari], a ZÖLD [ALMÁ]-T ette meg Mari.

$$
\text { VE } \quad \text { N-fej ellipszise }
$$

\section{Az N-fej ellipszise és zsilipelés}

Amikor az értelmezős szerkezet posztverbális pozícióban jelenik meg (a mondat lezárásaként), a második tagmondatból csak a zsilipelés segítségével lehet elliptálni az összetevőket. Ennek oka az, hogy nincs olyan ellipszisfajta, amely lehetővé tenné, hogy egy tagmondat elejéről is és végéről is elliptáljunk összetevőket. A zsilipelés alkalmazása esetén az értelmező fókuszhangsúlyt kap, és ebben az esetben a szerkezettagok eltérő szintaktikai pozícióban jelennek meg. A szórendi változatok közül három példamondat elemzését lehet elvégezni a fent vázolt módon.

1. Mari megette az almát, a ZÖLDET.

Mari megette az almát, a ZÖLD [almá]-T [ette meg Mari].

$$
\mathrm{N} \text {-fej ellipszise zsilipelés }
$$

5. Megette Mari az almát, a ZÖLDET.

Megette Mari az almát, a ZÖLD [almá]-T [e Mari].

$\mathrm{N}$-fej ellipszise zsilipelés 
7. MARI ette meg az almát, a ZÖLDET.

MARI ette meg az almát, a ZÖLD [almá]-T [ette meg Mari].

N-fej ellipszise zsilipelés

\section{Az N-fej ellipszise és RNR}

Az RNR-re, vagyis a jobb csomópontra való emelésre akkor van szükség, amikor hangsúlyos elemet kellene elliptálni, ami a visszakereshetőségi feltétel megsértésével járna. Mindkét tagmondatból az értelmezett és az értelmező után megjelenő összetevőket kiemeljük, jobbra kimozgatva őket, illetve az értelmezőn belül végbemegy az N-fej ellipszise. A tíz szórendi változatból kétféle mondat elemezhető ezen az úton.

4. Az almát, a zöldet Mari MEGette.

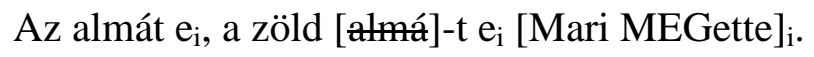

$$
\mathrm{N} \text {-fej ellipszise RNR }
$$

*Az almát [Mari MEGette], a zöld [almád-t Mari MEGette.

8. Az almát, a zöldet MARI ette meg.

Az almát $e_{i}$, a zöld [almá]-t $e_{i}[\text { MARI ette meg] }]_{i}$.

$$
\text { N-fej ellipszise RNR }
$$

*Az almát [MARIette meg], a zöld [almá]-t MARI ette meg.

\section{Az N-fej ellipszise és ATB-topikalizáció}

Ha van topik a mondatban, miközben az értelmezős szerkezet fókuszpozícióban jelenik meg, akkor a koordinált tagmondatokból az ATB-mozgatás révén a topikot a megfelelő pozícióba emeljük, majd ezt követi a visszaható ellipszis elvégzése, illetve az N-fej elliptálása. Az ATBtopikalizáció alkalmazása azért szükséges, mert nincs olyan ellipszisfajta, amellyel a második tagmondat elejéről és végéről is elliptálhatnánk összetevőket.

10. Mari az ALMÁT, a ZÖLDET ette meg.

Mari $_{i}$ az ALMÁT [vp[emeg] e e

ATB VE N-fej ellipszise

* Mari az ALMÁT [ette meg], [Mari] a ZÖLD [ALMÁ]-T ette meg. 


\section{Az N-fej ellipszise, ATB-topikalizáció és RNR}

Van két olyan szórendi változat, amikor az ATB-topikalizációra és az RNR-re is szükséges támaszkodni a szerkezet elemzése során. Az ATB-mozgatást ezekben a példákban is az váltja ki, hogy a második tagmondat különböző pontjain kellene végrehajtani az ellipszist. Az RNR egyrészt a fókuszhangsúlyos elem elliptálásának elkerülését szolgálja, másrészt a visszaható ellipszis célja nem lehet egy DP.

2. Mari az almát, a zöldet MEGette.

Mari $_{\mathrm{i}}$ az almát [vp $\mathrm{e}_{\mathrm{j}}\left[\mathrm{e}_{\mathrm{i}}\right]$, a zöld [almá]-t [vp e $\mathrm{e}_{\mathrm{j}}\left[\mathrm{e}_{\mathrm{i}}\right]$ [ [vPMEGette $\mathrm{e}_{\mathrm{i}}$ ].

ATB N-fej ellipszise RNR

*Mari az almát [MEGette], [Mari] a zöld [almá]-t MEGette.

6. Megette az almát, a zöldet Mari.

[vp Megette $e_{j} e_{i}$ az almát [vp $e_{j}\left[e_{i}\right]$, a zöld [almád-t [vp $\left.e_{j}\left[e_{i}\right]\right]$ Mari $i_{i}$.
ATB
$\mathrm{N}$-fej ellipszise
RNR

Összefoglalásként elmondható, hogy a hátravetett jelzői értelmezőt tartalmazó mondat összes szórendi változata a magyar nyelvben két tagmondat koordinációjaként és ellipszisként elemezhető. A tíz példamondat öt különféle szerkezettel írható le, amelyekben az N-fej ellipszise kombinálódik más ellipszisfajtákkal (zsilipelés, visszaható ellipszis), illetve mozgatásokkal (ATB-topikalizáció, RNR).

A fent ismertetett elemzés kompatibilis a hátravetett jelzői értelmező tulajdonságaival: 1) A szerkezettagok között megfigyelhető egyezés levezethető a koordinált tagmondatokon végrehajtott ellipszis által.

2) A nem metszetképző melléknevekre vonatkozó korlátozás (75a) azért egyeztethető össze az elliptikus felfogással, mert a koordinált tagmondatokon végrehajtott ellipszis során (75b) a két tagmondatban egy szembeállítás figyelhető meg.

(75) a. Elfogták a terroristákat, az állitólagosakat, míg a valódi terroristákat hagyták elfutni.

b. Az amerikaiak a terroristákat [fogták el], az angolok meg a bankrablókat fogták el. 
3) A számnévi értelmezőre vonatkozó korlátozás (76a) az ellipszis esetében is megfigyelhető: határozott DP-ből nem elliptálható az N-fej oly módon, hogy csak a névelő és a számnév (a megfelelő esetraggal ellátva) maradjon meg a szerkezetben (76b).

a. Meghívtam a fiúkat, *a kettöt / mind a kettöt / mindkettőjuiket.

b. János meghívta a két fiút, én meg elküldtem *a kettöt / mind a kettöt / mindkettöjüket.

4) Az értelmező korlátozó voltára is adható magyarázat az N-fej ellipszise által, hiszen egy jelzős szerkezetből - amelyben a jelző korlátozó értelmü - elliptáljuk az N-fejet (77).

az almát, a piros [almá]-at

5) Az értelmezős szerkezet tagjainak nem kell ugyanolyan határozottságúnak lennie (78a), és ez a tulajdonság összeegyeztethető az ellipszis azon jellemzőjével, mely szerint az elliptált rész és az antecedens Agr-jegyeinek nem kell megegyezniük (78b).
a. János egy almát, a legpirosabbat kéri.
b. János egy almát [kér], Péter meg a körtémet kéri.

A fentiekből levonható az a konklúzió, hogy a hátravetett jelzői értelmezős szerkezet két tagmondatként és ellipszisként való elemzése egy olyan elképzelés, amely a konstrukció tulajdonságaival is el tud számolni.

\section{6 Összefoglalás}

Ebben a fejezetben a hátravetett jelzői értelmező vizsgálatával foglalkoztam, megtartva a hagyományos terminust annak ellenére, hogy a szerkezetet nem sorolom a jelzők közé.

Először a hátravetett jelzői értelmező jellemzőit ismertettem, kiegészítve, illetve módosítva a leíró nyelvtanokban felsorolt tulajdonságokat. Pontosításra szorultak azok az állítások, amelyek szerint a hátravetett jelzői értelmezős konstrukciók átalakíthatóak elöl álló jelzős szerkezetté, illetve a szerkezettagokból alany-állítmányi viszony hozható létre. Egyrészt megtévesztő az ,átalakítás” fogalma generatív elméleti keretben dolgozva, másrészt csak bizonyos feltételek teljesülése mellett lehetséges a szerkezetek újrafogalmazása. Láthattuk azt is, hogy a 
nem metszetképző melléknévi értelmezők és a számnévi értelmezők esetében nem lehetséges predikatív viszony létrehozása az értelmezett szó és az értelmező között, illetve a felsőfokú melléknévi értelmező esetében további megszorítás szükséges az alany-állítmányi viszony létrehozásához. Továbbá fontos kihangsúlyozni a hátravetett jelzői értelmező korlátozó voltát, mivel az kiemelkedő szerepet tölt be az egyes értelmezőfajták elkülönítése során, és fontos érvként szolgál amellett, hogy a szerkezetet eltérő módon kell elemezni az azonosító értelmezőtől.

A hátravetett jelzői értelmezős szerkezet tagjai között egyeztetés helyett egyezést feltételezek, elkerülve ezzel, hogy az olvasó arra a téves következtetésre jusson, hogy a konstrukciót alárendelésnek tartom. A bemutatott példák alapján láthattuk, hogy kötelező az egyezés a szerkezettagok között az esetragok, a többes szám jele és az -é birtokjel tekintetében, ugyanakkor csak korlátozottan lehetséges, hogy az értelmezőn megjelenjen ugyanaz a birtokos személyjel, mint az értelmezett szón. Az -ék asszociatív többesjel esetében kötelező a többes számú egyezés, de az -ék jel teljes alakjában már nem tapadhat az értelmezőhöz. A névutók esetében szintén megfigyelhető az egyezés, de ha az értelmezős szerkezet tagjai nem távolodnak el egymástól, akkor abban az esetben is grammatikus a példánk, ha csak az értelmező után áll névutó. A szerkezettagok határozottságát tekintve nem kötelező az értelmezett szó és az értelmező egyezése.

Megvizsgáltam, hogy bármely elöl álló jelzős szerkezetből létrehozható-e értelmezős konstrukció. A példák alapján a következő konklúziók vonhatók le: ha a nem metszetképző melléknév nem olyan kontextusban fordul elő, amelyben szembeállítható egy másik melléknévvel, akkor nem töltheti be hátravetett jelzői értelmező szerepét, illetve a számnevek korlátozottan - bizonyos feltételek teljesülése esetén - jelenhetnek meg hátravetett jelzői értelmezőként.

Összehasonlítottam a magyar hátravetett jelzői értelmezőket a görög 'polydefinite' szerkezetekkel, amelyek között első pillantásra nagy hasonlóság fedezhető fel. Az összehasonlítás eredménye azt mutatja, hogy valójában több az eltérés a kétféle konstrukció között, mint a hasonlóság. Ennek a vizsgálatnak azért van nagy jelentősége, mert ezáltal közelebb juthatunk azoknak a kérdéseknek a megválaszolásához, hogy a magyar értelmezőket hogyan csoportosíthatjuk, illetve az egyes fajták milyen kapcsolatban állnak egymással. A görög 'polydefinite' szerkezettel való összehasonlítás során arra a következtetésre jutottam, hogy a hátravetett jelzői értelmező nem sorolható be a szoros appozíciók közé korlátozó volta ellenére, de ugyanezen tulajdonsága a laza appozíciók köréből is kizárja a vizsgált konstrukciót. Ez egy újabb érv amellett, hogy a magyarban a hátravetett jelzői és az azonosító értelmezőt egy- 
mástól elkülönítve vizsgáljuk, és hogy ne egy egységes szerkezetet akarjunk a két konstrukcióhoz rendelni, ahogyan a hagyományos nyelvtanok tették eddig.

A hátravetett jelzői értelmező szerkezeti elemzése során először elvetettem a korábbi elgondolásokat saját ellenérveim alapján: az alárendelés ellen a konstrukcióval való egyeztetés szól, a mellérendelő szintagma elleni fö érv a szerkezettagok szórendi szabadsága, az átmeneti szerkezet feltételezése pedig nem nyújt megoldást a problémára. Az én javaslatom, hogy a magyar nyelvben a hátravetett jelzői értelmezőt két tagmondat koordinációjaként és ellipszisként kell kezelni. Példákon keresztül szemléltettem, hogy az értelmezős szerkezet ily módon történő elemzése nem sérti az ellipszis feltételeit, vagyis a tartalom-azonosság, a kontextus-azonosság és a szomszédosság feltételei is teljesülnek. Két kisebb eredményt kell kiemelni: A vizsgálatok egyrészt alátámasztották, hogy a magyar példák esetében a visszaható ellipszisnél is lehetségesek az eltérő Agr-végződések. Másrészt Bánréti (2007) állításával ellentétben a szomszédosság feltételének is teljesülnie kell, mégpedig abban az esetben is, ha az értelmezett szó és az értelmező közé nem ékelődik be egy potenciális antecendens. A hátravetett jelzői értelmező elemzése során a következő ellipszisfajtákra és mozgatásokra építettem: N-fej ellipszise, visszaható ellipszis, zsilipelés, ATB-topikalizáció, RNR. Ezzel az ötféle müvelettel leírható az összes szórendi változata egy olyan mondatnak, amely hátravetett jelzői értelmezőt tartalmaz. Végül megmutattam, hogy ez a fajta elképzelés hogyan egyeztethető össze a hátravetett jelzői értelmezős szerkezet tulajdonságaival. 


\section{AZ AZONOSÍTÓ ÉRTELMEZŐ}

Ebben a fejezetben az azonosító értelmezővel kapcsolatos eredményeket fogom ismertetni, amely a következőképpen definiálható: két olyan tagból álló konstrukció, amelyek azonos szintaktikai pozícióban jelennek meg, azonos grammatikai funkciót látnak el, és az értelmezett szót azonosítja, kiegészíti, pontosítja vagy leszűkíti a második elem. A nemzetközi szakirodalomban használatos appozíció (apposition) fogalmának a magyarban az azonosító értelmező terminus felel meg, így a két kifejezést egymás szinonimájaként fogom használni. ${ }^{37}$

Először a vizsgált szerkezet jellemzőit mutatom be, reflektálva a szakirodalmak által összegyüjtött tulajdonságokra, kibővítve a magyar nyelvű leírások által nyújtott jellemzést. Kutatásom arra is kiterjed, hogy a magyar azonosító értelmező esetében van-e létjogosultsága a nemzetközi szakirodalom által megkülönböztetett egyes típusok elkülönítésének. Külön figyelmet szentelek a szerkezetben megjelenő kötőszók vizsgálatának, gazdag példatárra építve. A vizsgálat tárgyát képezi az is, hogy az alanyi, illetve tárgyi szerepben megjelenő azonosító értelmezőnek melyik tagja váltja ki az állítmánnyal való egyeztetést. A kérdésfelvetés azért indokolt, mert a kapott válaszok támpontot nyújthatnak annak eldöntéséhez, hogy lehetséges-e az azonosító értelmezőt alárendelésként, vagy éppen mellérendelésként elemezni. A konstrukció elemzése után még külön kitérek az 'én, a koronatanú' és a 'mi férfiak' típusú szerkezetekre. Ennek a fejezetnek a végére került a határozói értelmezők kérdésköre is.

\subsection{Az azonosító értelmező tulajdonságai}

Először nézzük meg, hogyan jellemezhető a magyar nyelvben az azonosító értelmező, illetve milyen módosításokat kell tennünk a hagyományos nyelvtanok állításait tekintve.

A magyar leíró nyelvtanok úgy határozzák meg az azonosító értelmezőt, hogy az olyan hátravetett jelző, amely nem alakítható át elöl álló jelzővé. Ezt az állítást két ponton is megtámadhatjuk: Egyrészt az értelmezőt nem sorolhatjuk a jelzők közé (1. Balogh 2003 érvelését az 1.1.4 pont alatti részben). Másrészt vannak olyan azonosító értelmezók, amelyekból létrehozható elöl álló jelzö, az (1)-es példákban - a hagyományos terminussal élve - kijelölő jelzőt kapunk, ha felcseréljük az értelmezett szó és az értelmező sorrendjét. A nemzetközi szakirodalomban azonban a hasonló példákat szoros értelmezőnek tekinthetjük, erre a megkülönböztetésre az 3.2.1 pont alatt fogok bővebben kitérni.

\footnotetext{
${ }^{37}$ Bár elismerem, hogy az azonosító értelmező terminus megtévesztő lehet abban az értelemben, hogy nem csak azokat a szerkezeteket értjük alatta, amelyekben a szerkezettagok között azonosítás történik, de ezen a ponton a hagyományt kívánom követni.
} 
A hátravetett jelzői értelmező és az azonosító értelmező közötti fontos különbség, hogy míg az előbbi korlátozó, addig az utóbbi (legalábbis a laza értelmező!) nem korlátozó olvasatot von maga után, hiszen abban általában két entitás (vagy esetleg cselekvés) azonosítása történik (2).
a. Mari, a barátnöm
b. a szomszédom, az orvos

A magyar példákban - az egyeztetés segítségével - nehéz bizonyítani az értelmezős szerkezetnek a mátrix mondattól való függetlenségét, mivel nem egyértelmű, hogy az állítmánnyal való egyeztetést az értelmezett szó vagy az értelmező irányítja (3). Erre a kérdésre a 3.4 pont alatt részletesen ki fogok térni.
a. A két barátnöd, a lányaim megérkeztek.
b. ?A lányaim, a két barátnöd megérkeztek.

A szakirodalomban a VP-ellipszist tartalmazó példákkal is alá szokták támasztani az értelmezőnek a mátrix mondattal való laza kapcsolatát: az ellipszis interpretálásában nem vesz részt az értelmezö. A magyar nyelvben a (4)-es adat áll legközelebb a többi szakirodalmi példához (Heringa 2012: 62).

(4) Meghívtam vacsorára Marit, János húgát, és Évát is. ${ }^{38}$

$\rightarrow$ Meghívtam vacsorára Marit, János húgát, és Évát is meghívtam vacsorára. † Meghívtam vacsorára Marit, János húgát, és Évát, János húgát is meghívtam vacsorára.

\footnotetext{
${ }^{38}$ Azt az esetet nem vizsgálom, amikor három személy meghívása történik, írásban az és kötőszó előtti vessző jelenléte vagy hiánya jelzi a különbséget.

(i) Meghívtam vacsorára Marit, János feleségét, és Évát is. (= Két személyt hívtam meg vacsorára.)

(ii) Meghívtam vacsorára Marit, János feleségét és Évát is. (= Három személyt hívtam meg vacsorára.)
} 
A magyar adatok csak részben támasztják alá azt a feltevést, hogy az értelmezős szerkezet valójában egy TP, amelynek saját ideje és alanya is van. Egyrészt az értelmezett és az értelmező esete mindig megegyezik (szemben egyes német példákkal, amelyekben az értelmező nominatívuszt visel az értelmezett esetétől függetlenül), másrészt a magyarban az időre utaló szavak gyakran az értelmező főnévi csoportján belül jelennek meg (5).

a. Egy híres író, [egy egykori alkoholista], lesz ma este a vendégünk.

b. *Egy híres író, egykor / valamikor [egy alkoholista], lesz ma este a vendégünk.

Az értelmező előtt megjelenhetnek bizonyos határozók a magyar appozíciós konstrukcióban is (6a), de ezek szerkezeti helye gyakran szintén az értelmező főnévi csoportján belül van (6b). Megjelenésüket az utóbbi esetben az teszi lehetővé, hogy az értelmezőnek van egy olyan melléknévi vagy igenévi adjunktuma, amelynek már lehet határozói bővítménye.

a. A faji kérdésröl, [sajnálatos módon egy igen gyakori problémáról] csak hallgatnak a politikusok.

b. Az FTC, [gyakran a legkeményebben küzdö csapat] csupán 3. lett a bajnokságon.

A fentiekből adódik, hogy a határozók nemcsak azokban a példákban jelenthetnek meg, amelyek az Ott (2014)-féle osztályozás alapján a predikációs appozíciók alá sorolhatóak be. Ha a specifikációs appozícióban is van az értelmezőnek olyan adjunktuma, amely megengedi egy határozó megjelenését, akkor ezekben a példákban is lehetséges a határozók beékelése az értelmezős szerkezet tagjai közé (7a). Sőt olyan specifikációs értelmező is generálható (7b), amelyben a határozó az értelmező főnévi csoportján kívül foglal helyet.

(7) a. Egy keményen küzdö csapat, gyakran a legtöbb gólt rúgó FTC csupán 3. lett a bajnokságon.

b. Egy híres író, fiatal korában / fiatalon Illyés barátja újabb verseskötetet adott $k i$.

A (7b) példa megkérdőjelezi azt a nézetet, hogy a specifikációs appozíciót nem lehet határozóval módosítani (Ott 2014). 
A magyar nyelvben is található olyan példa, amelyben saját alanya van az appozíciós konstrukciónak (8).

(8) A tanárom, egykor maga is nagy dohányos, támogatott, hogy leszokjak a dohányzásról.

A (8)-as példában az értelmezőhöz kapcsolódva jelenik meg a maga visszaható névmás, amelyet egy alanynak kell engedélyeznie, ebből adódóan az appozíciós szerkezetnek egy saját pro alannyal kell rendelkeznie. A (8)-as adat esetében egy értelmezős szerkezettel állunk szemben, és nem egy közbevetett tagmondattal, amit az igazol, hogy hiányzik a múlt idejü állítmány a szerkezetből. Ha azonban megjelenik egy állítmány a szerkezetben, akkor többé már nem beszélhetünk értelmezős konstrukcióról. Ebben az esetben kétféleképpen tehetjük jól formálttá a mondatot. Az egyik lehetőség, hogy vonatkozó tagmondattá alakítjuk az eredetileg appozíciós szerkezetet (A tanárom, aki egykor maga is nagy dohányos volt, támogatott...). A másik út, hogy az értelmezős konstrukciót jellemző intonációs szünetnél még nagyobb szünetet tartunk, kiemelve a gondolat közbevetéses jellegét (A tanárom - egykor maga is nagy dohányos volt - támogatott...). Érdemes végiggondolni azt a kérdést, hogy ha az értelmezőt a közbevetések közé soroljuk, akkor van-e határ az appozíciók és a valódi parentetikus gondolatok között, vagy pedig egy kontinuum mentén helyezkednek el ezek a szerkezetek, és nem húzható éles határvonal közéjük.

Az állítólag, valószínüleg mondathatározók megjelenése egy fontos különbség felismeréséhez vezet a predikációs és a specifikációs értelmezőket illetően (9-10).

a. Az FTC-vel, állitólag egy jó csapattal fogunk készíteni egy interjút.

b. Egy jó csapattal, állítólag az FTC-vel fogunk készíteni egy interjút.

a. Kiss Kata, valószínüleg egy leendö szépségkirálynö lesz ma este a vendégünk.

b. Egy leendö szépségkirálynö, valószínüleg Kiss Kata lesz ma este a vendégünk.

(9a)-ban egy predikációs appozíció jelenik meg, és itt a másodlagos propozíció az, hogy az FTC állítólag egy jó csapat. (9b)-ben azonban már specifikációs appozíció található, és itt az állítólag mondathatározó arra vonatkozik, hogy az FTC-vel fogunk készíteni egy interjút. A (10)-es példában hasonlóan alakul a két mondat interpretációja: (10a)-ban egy predikációs appozíciót láthatunk, ahol a másodlagos predikáció az, hogy Kiss Kata valószínüleg egy leendö szépségkirálynő, míg (10b)-ben a specifikációs appozíció esetében azt állítjuk, valószínü- 
leg Kiss Kata lesz ma este a vendégünk. Ezen példák interpretációja alátámaszthatja az Ott (2014) által felvázolt kétféle szerkezeti elemzés létjogosultságát.

További mondathatározók: feltehetőleg, feltétlenül, bizonyára, alighanem, kétségtelenül, tényleg, tulajdonképpen, esetleg, valamint idesorolhatjuk a kétértelmü mondathatározókat is, mint amilyen a szerencsére, természetesen, biztosan, szokatlanul. A felsorolt mondathatározók némelyike azonban csak a predikációs nominális értelmezőben jelenhet meg, a specifikációsban nem (11-12).

(11) a. Kiss Jánosról, bizonyára egy igen erős emberrỏl még sokat hallhatunk.

b. *Egy igen erös emberröl, bizonyára Kiss Jánosról még sokat hallhatunk.

a. Nagy Annának, tényleg egy kiváló festőnek nyílt meg ma a kiállítása.

b. *Egy kiváló festőnek, tényleg Nagy Annának nyílt meg ma a kiállítása.

\subsection{Az azonosító értelmező fajtái}

Ebben az alfejezetben azt fogom bemutatni, hogy a magyar nyelvben milyen módon lehet az azonosító értelmező egyes példáit csoportosítani. A magyar szakirodalomban az azonosító appozíciókat vagy az értelmező szófaja (lásd Simonyi 1913, Károly 1958) vagy az értelmező funkciója (lásd Balogh 2004) felől megközelítve csoportosították. Az alábbiakban a nemzetközi szakirodalomra reflektálva mutatok be két újfajta megközelítési módot.

\subsubsection{A szoros és a laza értelmező}

Felmerül a kérdés, hogy mit kezdjünk azokkal a példákkal (13), amelyek levezethetők az azonosító értelmezőkből (14), de mégsem viselkednek ugyanúgy.

a. a fodrász Mari

b. a pápa Miltiadész
a. a fodrász, Mari
b. Mari, a fodrász
c. a pápa, Miltiadész
d. Miltiadész, a pápa

Károly (1958: 23) megjegyzi, hogy külföldön ,,az általános grammatikai felfogás szerint az értelmező (appozíció) tartalmilag szükebb kategória, mint a mi értelmezőnk, mert csak a főn- 
évi jelzős szerkezetekre korlátozódik, de mondatfunkciós és formai szempontból tágabb, mert nemcsak a laza szerkezeteket foglalja magába, hanem az összes főnévi jelzős szerkezeteket”. A nemzetközi szakirodalmat tárgyaló fejezetben láthattuk, hogyan különböztetik meg az azonosító értelmezőn belül a laza és a szoros értelmező két csoportját.

A következő érvet hozhatjuk fel amellett, hogy a magyar nyelvben is van létjogosultsága a szoros értelmezőnek: Ha összehasonlítjuk a (15a) és (15c) példákat, azt láthatjuk, hogy a laza értelmezős szerkezetből (15a) elhagyható az értelmező (15b), a mondat grammatikalitása nem változik meg. Ezzel szemben a (15c) példában nem jelenhet meg laza értelmezö, hiszen annak elhagyása esetén agrammatikus mondatot (15d) kapunk. Így csakis a szoros értelmezős szerkezet állhat a (15c)-ben, hiszen itt követelmény a szerkezet korlátozó tulajdonsága (márpedig a laza értelmezős szerkezet sosem korlátozó).

(15) a. Mari, a barátnöm sokkal népszerübb, mint Éva, a húgom.

b. Mari sokkal népszerübb, mint Éva.

c. Miltiadész a hadvezér sokkal ismertebb, mint Miltiadész a pápa.

d. *Miltiadész sokkal ismertebb, mint Miltiadész.

Az angol szoros értelmezőben felcserélhető a két DP (16), nézzük meg, ez hogyan történik a magyar nyelvben (16).

a. the poet Burns

[angol] 'a költő Burns'

b. Burns the poet 'Burns a költö'

a. A hadvezér Miltiadészt sokkal többen ismerik, mint a pápa Miltiadészt.

b. Miltiadészt a hadvezért sokkal többen ismerik, mint Miltiadészt a pápát.

c. Miltiadész a hadvezér jóval ismertebb Miltiadésznál a pápánál.

Ha a nemzetközi szakirodalom példái alapján szoros értelmezőnek tekintjük a (17)-es adatokat, akkor ki kell emelnünk egy feltünő különbséget a kétféle szerkezet között: ha az értelmező áll elöl, nem veszi fel az értelmezett szó esetragját (17a), míg ha az értelmező követi az értelmezettet, akkor ugyanazt az esetvégződést viseli $(17 \mathrm{~b}, \mathrm{c})$. A példák egy részére még viszsza fogok térni az 4.2.2 pont alatti részben, megvizsgálva, hogy a fodrász Mari típusú szerkezetek esetében valóban szoros értelmezőt kell-e feltételeznünk. 
A laza értelmező tagjai közé más elemek is beékelödhetnek (az angolban például a namely 'azaz', or rather 'illetve', in other words 'más szavakkal'). A magyar nyelvben is találunk hasonló adatokat (18).
a. Mari, vagyis a barátnöm
b. Juli, azaz a fodrászom

A (18)-as példákat a magyar hagyományos nyelvtanok mellérendelő szószerkezetnek tartják, azon belül a kifejtő magyarázók közé sorolják. Ezek nem valódi mellérendelések, mivel ugyanarra az entitásra vonatkozik a szerkezet két tagja, ebből adódóan érdemes lenne elgondolkodni azon a lehetőségen, hogy ezeket is az értelmezők közé soroljuk be a jövőben, erre a kérdésre még visszatérek a kötőszókat tárgyaló alfejezetben.

Az egyik fő különbség az intonációban jelentkezik: a szoros értelmező egyetlen intonációs egységet alkot (19a), míg a laza értelmező két tagja elkülönül a vessző-intonáció által (19b).

Szoros értelmezői viszonyba csak DP-k kerülhetnek (19a), míg a laza értelmezői viszony lehetséges bármilyen két azonos kategória között (19b).
a. [DP Miltiadész] [DP a pápa]
b. [vp leszidta], [vp megdorgálta]

A szoros értelmező korlátozó, míg a laza értelmező nem korlátozó olvasatot von maga után. A szoros értelmező olyan kontextusban (20a) használható, amikor több individuum közül nevezünk meg egyet, a szerkezet két tagja együttesen határozza meg az adott entitásra utaló referenciát. (20b)-ben csupán egyetlen olyan individuum merül fel, akinek Miltiadész a neve, ezért használhatjuk ebben a kontextusban a laza értelmezős konstrukciót.

(20) a. A: Úgy hallottam, hogy a meghirdetett elöadás Miltiadészról fog szólni, csak azt nem tudom, hogy a hadvezérröl vagy a pápáról.

B: Mivel elsösorban az ókori görögöket tanulmányozom, így természetesen Miltiadészról a hadvezérrōl / \# Miltiadészról, a hadvezérröl fogok beszélni.

b. A: Úgy hallottam, hogy a ma esti elöadás az ókori görög harcokról fog szólni.

B: Igen, egész pontosan Miltiadészról, a hadvezérröl / \# Miltiadészról a hadvezérról fogok beszélni. 
Fontos azonban kihangsúlyozni, hogy ez a viszony nem csak több individuum feltételezése esetén jelenhet meg. Lehetséges olyan kontextus is, amelyben egyetlen individuum szerepel értelmezettként (21), amelynek azonban két különböző tulajdonságát szeretnénk kiemelni vagy különböző tulajdonságai közül szeretnénk választani.
a. Petöfi a költő sikeresebb volt Petöfinél a katonánál.
b. Bevallom, Kosztolányit az írót jobban kedvelem, mint Kosztolányit a költöt.

Hasonló adatok már Simonyi (1913)-ban is megjelentek (1. az 1.1.1 pont alatti alfejezetben a (8)-as példákat).

Összegezve az eddigieket, amellett foglalok állást, hogy a magyar nyelvben is beszélhetünk szoros értelmezőről, bár ezek korlátozottabb számban jelennek meg. Csak azokat a szerkezeteket nevezem szoros appozíciónak a magyar nyelvben, amelyeknek mindkét tagját ugyanúgy ellátjuk a megfelelő esetragokkal. Ha egy szerkezetnek csak a második tagja visel esetet, akkor azt már nem szoros értelmezőnek, hanem főnévi módosítónak fogom tartani (a 4.2.2 pont alatt még visszatérek erre a kérdésre, egy újabb érvet ismertetve). Ebből adódik az a következmény is, hogy a magyarban nem cserélhető fel az értelmezős konstrukció tagjainak a sorrendje.

\subsubsection{A Heringa-féle szemantikai osztályok}

A következőkben Heringa (2012) szemantikai osztályait (azonosítás, tulajdonítás, bennfoglalás) veszem sorra, megvizsgálva, hogy a magyar példák mennyire különíthetők el az értelmezett szónak és az értelmezőnek a specifikussági skálán betöltött helye szerint. További cél a kötőszók, pontosabban az appozíció-jelölők vizsgálata, hogy azok vajon a magyar nyelvben is besorolhatók-e a három szemantikai osztály egyikébe az angol, a német és a holland minta alapján.

Az azonosítás esetében az az elvárás, hogy a szerkezet mindkét tagja a specifikussági skála azonos helyén jelenjen meg, továbbá Heringa megengedi - a holland példák alapján -, hogy a specifikusság különféle változatai egymással való kombinációkat is létrehozzanak. Ezeket a további kombinációkat a magyar példák is alátámasztják, ahogyan a 7. táblázat mutatja. (A lehetséges kombinációkat a satírozott cellák jelölik, tartalmazva az adott példamondat számát). 
7. táblázat: Az azonosítás magyar példái

\begin{tabular}{|c|c|c|c|c|c|c|c|}
\hline értelmező & $\begin{array}{l}\text { generi- } \\
\text { kus hatá- } \\
\text { rozott }\end{array}$ & $\begin{array}{l}\text { generi- } \\
\text { kus hat.- } \\
\text { lan }\end{array}$ & $\begin{array}{l}\text { generi- } \\
\text { kus hat. } \\
\text { egyéni } \\
\text { fogalom }\end{array}$ & $\begin{array}{l}\text { nem- } \\
\text { specifi- } \\
\text { kus }\end{array}$ & $\begin{array}{l}\text { specifikus } \\
\text { határozat- } \\
\text { lan }\end{array}$ & $\begin{array}{l}\text { specifi- } \\
\text { kus hatá- } \\
\text { rozott }\end{array}$ & $\begin{array}{l}\text { specifikus } \\
\text { tulajdon- } \\
\text { név }\end{array}$ \\
\hline $\begin{array}{l}\text { generikus } \\
\text { határozott }\end{array}$ & (23a) & & & & & & \\
\hline $\begin{array}{l}\text { generikus } \\
\text { hat.-lan }\end{array}$ & & $(23 b)$ & & & & & \\
\hline $\begin{array}{l}\text { gen. hat. } \\
\text { egyéni f. }\end{array}$ & & & $(23 c)$ & & & & \\
\hline $\begin{array}{l}\text { nem- } \\
\text { specifikus }\end{array}$ & & & & (24) & & & \\
\hline $\begin{array}{l}\text { specifikus } \\
\text { hat.-lan }\end{array}$ & & & & & (22a) & $(22 b)$ & $(22 c)$ \\
\hline $\begin{array}{l}\text { specifikus } \\
\text { határozott }\end{array}$ & & & & & $(22 d)$ & $(22 \mathrm{e})$ & $(22 f)$ \\
\hline $\begin{array}{l}\text { spec. tu- } \\
\text { lajdonnév }\end{array}$ & & & & & $(22 \mathrm{~g})$ & $(22 \mathrm{~h})$ & (22i) \\
\hline
\end{tabular}

(22) a. János az órán rajzolt egy szvasztikát, azaz egy horogkeresztet, bár ez a tanárának nagyon nem tetszett.

b. Péter egy autóval, mégpedig Jánosnak ezzel a kis dömperével, játszik.

c. Mari egy játék babát, mégpedig a Gyöngyhercegnöt kérte karácsonyra.

d. Péter bohóca, vagyis egy bizonyos ajándék a barátjától, elveszett.

e. Mari babája, mégpedig a nagymamájától kapott játék, megsérült.

f. Mari babája, pontosabban kifejezve a Gyöngyhercegnö, beesett az ágy mögé.

g. A Gyöngyhercegnö, azaz egy a nagymamától kapott játék baba, a lányom kedvencévé vált.

h. Elfelejtettem becsomagolni a böröndbe a Gyöngyhercegnöt, vagyis Mari babáját.

i. A Vénusz, vagyis az Esthajnalcsillag segítette az embereket tájékozódni az utazásaik során. 
a. A koala, azaz a phascolarctos cinereus Ausztráliában honos erszényes.

a'. A tanárunk elöadást tartott az év madaráról, vagyis a túzokról.

b. Egy tarajos göte, vagyis egy szalamandraféle csigákat, rovarokat eszik.

c. A világ legnagyobb hatalmú férfija, érthetöbben mondva az USA elnöke, a Fehér Házban él.

A tulajdonítás esetében az értelmező generikus, míg az értelmezett bárhol lehet a specifikussági skálán, a satírozott négyzetek jelzik a lehetséges kombinációkat a 8. táblázatban. Az üresen hagyott színes négyzetek kombinációira nem találtam magyar példákat (ahogyan Heringa sem tudott felmutatni holland adatokat ezek esetében). ${ }^{39}$

8. táblázat: A tulajdonítás magyar példái

\begin{tabular}{|c|c|c|c|c|c|}
\hline értelmezet & $\begin{array}{l}\text { generikus } \\
\text { határozott }\end{array}$ & $\begin{array}{l}\text { generikus } \\
\text { hat.-lan }\end{array}$ & $\begin{array}{l}\text { generikus } \\
\text { hat. egyéni } \\
\text { fogalom }\end{array}$ & $\begin{array}{l}\text { nem- } \\
\text { specifikus }\end{array}$ & specifikus \\
\hline $\begin{array}{l}\text { generikus } \\
\text { határozott }\end{array}$ & & $(25 a)$ & (26a) & & \\
\hline $\begin{array}{l}\text { generikus } \\
\text { hat.-lan }\end{array}$ & & $(25 b)$ & $(26 b)$ & & \\
\hline $\begin{array}{l}\text { gen. hat. } \\
\text { egyéni f. }\end{array}$ & & $(25 c)$ & $(26 c)$ & & \\
\hline $\begin{array}{l}\text { nem- } \\
\text { specifikus }\end{array}$ & & $(25 d)$ & $(26 d)$ & & \\
\hline $\begin{array}{l}\text { specifikus } \\
\text { hat.-lan }\end{array}$ & & $(25 e)$ & $(26 e)$ & & \\
\hline $\begin{array}{l}\text { specifikus } \\
\text { határozott }\end{array}$ & & $(25 f)$ & (26f) & & \\
\hline $\begin{array}{l}\text { specifikus } \\
\text { tulajdonnév }\end{array}$ & & $(25 \mathrm{~g})$ & (26g) & & \\
\hline
\end{tabular}

${ }^{39}$ Heringa (2012) a következő magyarázatot adja arra, hogy miért nem lehetségesek a tulajdonítás esetében azok a kombinációk, amelyekben az értelmező mint generikus határozott jelenik meg: Ezek a kombinációk azért hiányoznak, mert a határozott generikus főnévi frázis egy teljes osztályra utal, aminek következtében nincs olyan változó, amely az osztály valamely egyéni tagjára utalna, vagyis a határozott generikus NP-t nem lehet összekapcsolni egyéni tagokra utaló referensekkel. 
(25) a. A tricikli, (azaz) egy háromkerekü bicikli igen népszerü a kisgyerekek körében.

b. Egy tandem kerékpár, egy kétüléses bicikli mindig jól jöhet a szerelmeseknek.

c. Az év tanárát, egy lelkes és kiváló pedagógust, a diákok választják meg.

d. János egy kockát, egy háromdimenziós testet akart rajzolni azórán.

e. János egy bizonyos autót, egy négykerék-meghajtású járgányt akart megvenni.

f. János számszeríja, tudvalevöleg egy gyilkos fegyver, nagyon veszélyes.

g. A Gyöngyhercegnö, amint tudod/mellesleg egy játék baba, nagyon népszerü Magyarországon.

(26) a. Az orrszarvút, a dél-afrikai vadorzók áldozatát a kihalás veszélye fenyegeti.

b. Egy leopárd, mellesleg Kenya legveszélyesebb állata, rendszerint antilopot eszik.

c. Az év tanárát, a legkiválóbb pedagógust kitüntették.

d. János egy iPadot, a mai fiatalok legkeresettebb kütyüjét kérte karácsonyra.

e. János megütötte egy osztálytársát, az iskola kedvencét.

f. A növérem, az iskola legjobb tanulója könyvjutalmat kapott év végén.

g. A Louvre-t, Európa legnépszerübb múzeumát évente több százezren látogatják.

A bennfoglalás esetében az értelmező specifikusabb, mint az értelmezett. Bár az elvárások szerint létezhetne olyan szerkezet, amelyben az értelmezett és az értelmező is egy-egy specifikus tulajdonnév, de ilyen példát nem sikerült találni (ahogyan ez látható az üresen maradt kiszínezett cellából).

9. táblázat: A bennfoglalás magyar példái

\begin{tabular}{|c|l|l|l|l|l|l|l|}
\hline $\begin{array}{c}\text { értelme- } \\
\text { zó }\end{array}$ & $\begin{array}{l}\text { generi- } \\
\text { kus hatá- } \\
\text { értel- } \\
\text { mezett }\end{array}$ & $\begin{array}{l}\text { generi- } \\
\text { kus hat.- } \\
\text { lan }\end{array}$ & $\begin{array}{l}\text { generi- } \\
\text { kus hat. } \\
\text { egyéni } \\
\text { fogalom }\end{array}$ & $\begin{array}{l}\text { nem- } \\
\text { specifikus }\end{array}$ & $\begin{array}{l}\text { specifikus } \\
\text { határozat- } \\
\text { lan }\end{array}$ & $\begin{array}{l}\text { specifi- } \\
\text { kus hatá- } \\
\text { rozott }\end{array}$ & $\begin{array}{l}\text { specifikus } \\
\text { tulajdon- } \\
\text { név }\end{array}$ \\
\hline $\begin{array}{l}\text { gen. ha- } \\
\text { tározott }\end{array}$ & $(28 \mathrm{a})$ & $(28 \mathrm{~b})$ & $(28 \mathrm{c})$ & & & & \\
\hline
\end{tabular}




\begin{tabular}{|c|c|c|c|c|c|c|c|}
\hline $\begin{array}{l}\text { gen. hat.- } \\
\text { lan }\end{array}$ & $(28 \mathrm{~d})$ & $(28 \mathrm{e})$ & (28f) & & (29a) & $(29 b)$ & $(29 c)$ \\
\hline $\begin{array}{l}\text { gen. hat. } \\
\text { egyéni f. }\end{array}$ & $(28 g)$ & $(28 \mathrm{~h})$ & (28i) & & $(29 d)$ & $(29 e)$ & (29f) \\
\hline $\begin{array}{l}\text { nem- } \\
\text { spec. }\end{array}$ & & & & $(29 g)$ & (29h) & (29i) & (29j) \\
\hline $\begin{array}{l}\text { spec. } \\
\text { hat.-lan }\end{array}$ & & & & & $(27 e)$ & (27a) & $(27 b)$ \\
\hline $\begin{array}{l}\text { spec. } \\
\text { hat. }\end{array}$ & & & & & & $(27 c)$ & $(27 d)$ \\
\hline $\begin{array}{l}\text { spec. } \\
\text { tul.név }\end{array}$ & & & & & & & \\
\hline & $\begin{array}{l}\text { generikus } \\
\text { határozott }\end{array}$ & $\begin{array}{l}\text { generikus } \\
\text { hat.-lan }\end{array}$ & $\begin{array}{l}\text { generikus } \\
\text { hat. } \\
\text { egyéni } \\
\text { fogalom }\end{array}$ & $\begin{array}{l}\text { nem- } \\
\text { specifikus }\end{array}$ & $\begin{array}{l}\text { specifikus } \\
\text { határozat- } \\
\text { lan }\end{array}$ & $\begin{array}{l}\text { specifikus } \\
\text { határozott }\end{array}$ & $\begin{array}{l}\text { specifikus } \\
\text { tulajdonnév }\end{array}$ \\
\hline
\end{tabular}

(27) a. Blanka néhány plüssállattal, köztük Mari játék mackójával játszik reggel óta.

b. Blanka néhány babával, köztük a Gyöngyhercegnövel játszott.

c. János elvesztette a kedvenc autóit, beleértve a mamájától kapott versenyautót is.

d. A Jupiter holdjai, köztük a Galilei-holdak, egy ellipszis alakú pályán keringenek.

(e. Mari vett néhány játékot, köztuik egy beszélö babát.)

(28) a. A ragadozó madarak, különösen/például a sasok, éles karmokkal bírnak.

b. A sólyom, de különösen egy kabasólyom, nagyon sok idöt tölt a levegöben.

c. Az orrszarvú, föképpen a kicsinyeit védö szülö, nagyon veszélyes lehet.

d. Egy macskafélének, de leginkább a tigrisnek, gyönyörü bundája van.

e. Egy nagy ragadozó, például egy oroszlán a táplálkozási lánc csúcsán van.

f. Egy emberszabású majom, de fóként az alfahímek csoportja, támogatja a rokonait.

g. János kedvenc állatai, köztük a koala, kivétel nélkül veszélyeztetett fajok. 
h. Egy igazgatási egység vezetője, úgymint egy dékán, gyakran nagy tisztelettel bír.

i. Egy közösség vezetöjének, úgymint egy iskola igazgatójának, jól kell ismernie a beosztottjait.

(29) a. Egy háziállatnak, de különösen Péter egy bizonyos mandarinhalának, sok törödésre van szüksége.

b. Egy háziállat, úgymint János hüllője, sok gondoskodást igényel.

c. Egy luxusautó, úgymint a Lexus, a közemberek számára megfizethetetlen.

d. Az emberszabású majmok alfahímjét, úgymint a pesti állatkert egy bizonyos gorilláját, még az emberekkel szemben is domináns viselkedés jellemzi.

e. Egy gyüjtö mintadarabjának, például Péter egyfilléres érmének, mindig ragyogóan kell kinéznie.

f. Európa híres múzeumait, de különösen/köztük a Louvre-t, rengetegen látogatják.

g. János egy háziállatot, például egy gőtét szeretne kapni a szülinapjára.

h. János le akar rajzolni néhány játékot, köztiik Péternek egy autóját.

i. János is venni akar egy feltünö járgányt, mint például Péter luxusautóját.

j. Jánosnak a projektmunkáját egy ürhajóról, például a Vosztok-1-röl kell elkészítenie.

Ha az értelmezett és az értelmező lehetséges specifikussági kombinációt összegezzük a fenti példák alapján a háromféle szemantikai csoport tekintetében, akkor a 10. táblázatot kapjuk. A következő szimbólumokat alkalmaztam: az azonosítás jele '=’, a tulajdonítás jele '>’, a bennfoglalás jele '<'.

10. táblázat: A lehetséges kombinációk összegzése

\begin{tabular}{|c|c|c|c|c|c|c|c|}
\hline értelmezett & $\begin{array}{l}\text { gen. } \\
\text { határo- } \\
\text { zott }\end{array}$ & $\begin{array}{l}\text { gen. } \\
\text { határo- } \\
\text { zatlan }\end{array}$ & $\begin{array}{l}\text { gen. } \\
\text { egyéni } \\
\text { fog. }\end{array}$ & $\begin{array}{l}\text { nem- } \\
\text { spec. }\end{array}$ & $\begin{array}{l}\text { spec. } \\
\text { határo- } \\
\text { zatlan }\end{array}$ & $\begin{array}{l}\text { spec. } \\
\text { határo- } \\
\text { zott }\end{array}$ & $\begin{array}{l}\text { spec. } \\
\text { tul.-név }\end{array}$ \\
\hline gen. határozott & $=$ & $><$ & $><$ & & & & \\
\hline gen. hat.-lan & $<$ & $=><$ & $><$ & & $<$ & $<$ & $<$ \\
\hline gen. egyéni fog. & $<$ & $><$ & $=><$ & & $<$ & $<$ & $<$ \\
\hline nem-spec. & & $>$ & $>$ & $=$ & $<$ & $<$ & $<$ \\
\hline spec. hat.-lan & & $>$ & $>$ & & $=$ & $=$ & $=$ \\
\hline spec. hat. & & $>$ & $>$ & & $=$ & $=$ & $=$ \\
\hline spec. tul.név & & $>$ & $>$ & & $=$ & $=$ & $=$ \\
\hline
\end{tabular}


Amint látható a táblázatból, vannak olyan kombinációk, amelyek két vagy akár mindhárom szemantikai osztály értelmezős szerkezeteire jellemzőek lehetnek (pl. generikus határozatlan - generikus határozatlan). Az angol, a német és a holland adatok esetében ez azért nem jelent problémát egy-egy példa osztályozása során, mert a szerkezettagok között megjelenő appozíció-jelölők egyértelmüen eldöntik, hogy a példa melyik szemantikai osztályba sorolható. A magyar adatok esetében azonban látni fogjuk a 3.3 pont alatti alfejezetben, hogy egyes appozíció-jelölők nem kapcsolódnak feltétlenül egyetlen szemantikai osztályhoz.

Heringa (2012: 47-48) egy tesztet alkalmaz a tulajdonító appozíciónak a másik két értelmezőfajtától való elkülönítésére. Holland példákon keresztül megmutatja, hogy csak a tulajdonító appozíció esetében lehetséges a szerkezet átalakítása oly módon, hogy egy értelmezői vonatkozó tagmondatot ékelünk be az értelmező helyére (30).

a. Het prisma, dat/wat een ruimtelijke figuur is, heeft toepassingen a prizma amely egy háromdimenziós alak COP birtokol alkalmazások in de optiek. [holland]

IN az optika

'A prizmát, amely egy háromdimenziós alak, az optikában alkalmazzák.'

b. *De reuzenpanda, die de pandabeer is, eet voornamelijk bamboe.

a óriáspanda amelyik a pandamaci COP eszik főként bambusznád *‘Az óriáspanda, amely a pandamaci, főként bambusznádat eszik.’

Ez a teszt azonban nem alkalmazható teljes mértékben a magyar példákra: bár a bennfoglalás példái esetében valóban nem lehet az értelmezőt átalakítani értelmezői vonatkozó tagmondattá (31), de ugyanez nem mondható el az azonosítás összes példájáról (32). A könnyebb követhetőség kedvéért megismétlem a korábbi példákat, feltüntetve az eredeti sorszámukat.

a. *Blanka néhány babával, amely a Gyöngyhercegnő, játszott. (27b)

b. *A sólyom, amely egy kabasólyom, nagyon sok idöt tölt a levegöben. (28b)

a. Péter bohóca, amely egy bizonyos játék a barátjától, elveszett. (22d)

b. A Gyöngyhercegnö, amely egy a nagymamától kapott játék baba, a lányom kedvencévé vált. (22g)

Amint már láthattuk, Heringa (2012) megmutatja, hogy a tulajdonító appozíció két tagjából létrehozható egy predikációs kopulás tagmondat, amelyben - a tulajdonító értelmezőhöz 
hasonlóan - a predikátum egy tulajdonságot rendel hozzá az alanyhoz. Az azonosító appozíció pedig egy azonosító kopulás mondattá alakítható át, amely egyenlővé teszi az alany és a predikátum referensét. A bennfoglaló appozíció viszont nem alakítható át kopulás tagmondattá.

A magyar nyelvészetben is különbséget tesznek kétféle nominális predikátum között: a minősítő állítmány besoroló, osztályozó vagy tulajdonító (33), míg az azonosító állítmány a szerkezet két tagjának referensét azonosítja egymással (34).
a. Péter katona.
b. Hamupipőke és Piroska ismert mesehösök.
c. A sas ragadozó madár.
d. Az a festmény az enyém.
b. János a tettes.
c. Decsi Sándor az én becsületes nevem.

(34) a. Péter a kapus.

Ha megvizsgáljuk a magyar példákat abból a szempontból, hogy az értelmezős szerkezet tagjai között létrehozható-e a predikatív viszony, akkor látható, hogy a bennfoglalás szemantikai osztályába tartozó adatok egyikében sem lehet az értelmezett szót és az értelmezőt predikatív viszonyba állítani (35).
a. *néhány plüssállat Mari játék mackója (27a)
b. *néhány baba a Gyöngyhercegnö (27b)
c. *a kedvenc autói a mamájától kapott versenyautó (27c)
d. *a ragadozó madarak a sasok (28a)

Ugyanakkor az azonosítás és a tulajdonítás osztályába tartozó példák között is találhatóak olyanok, amelyekben - ellentétben az elvárásokkal - nem hozható létre predikatív viszony a szerkezettagok között (36).
a. *egy szvasztika egy horogkereszt (22a)
b. *egy tandem kerékpár egy kétüléses bicikli (25b)
c. *egy bizonyos autó egy négykerék-meghajtású járgány (25e) 
Továbbá a példák egy részében az is megfigyelhető, hogy nem az értelmezett szóról, hanem az értelmezőről predikálunk valamit (37).
a. egy autó Jánosnak ez a kis dömpere (22b)
b. egy játék baba a Gyöngyhercegnö (22c)
c. Mari babája a Gyöngyhercegnö (22f)

Az azonosítás szemantikai osztályába tartozó példák többségéről valóban elmondható, hogy a szerkezettagokból létrehozott predikatív viszonyban általában azonosító állítmány jelenik meg (38a-c), azonban találunk kivételt is (38d).
a. Mari babája a nagymamájától kapott játék (22e)
b. a Gyöngyhercegnő Mari babája (22h)
c. az év madara a túzok (23a')
d. Péter bohóca egy bizonyos ajándék a barátjától (22d)

A tulajdonítás példáiban valóban minősítő állítmányként funkcionál az értelmező a szerkezettagok közti alany-állítmány viszonyban (39a-c).
a. a tricikli egy háromkerekü bicikli (25a)
b. az év tanára egy lelkes és kiváló pedagógus (25c)
c. az orrszarvú a dél-afrikai vadorzók áldozata (26a)

További nagyon fontos különbség a bennfoglalás osztályába és a másik két osztályba tartozó példák között, hogy az előbbi esetében nem hagyható el az appozíció-jelölő anélkül, hogy a mondat ne válna agrammatikussá (40).
a. *Blanka néhány babával, a Gyöngyhercegnövel játszott. (27b)
b. ??A ragadozó madarak, a sasok, éles karmokkal bírnak. (28a)
c. *A sólyom, egy kabasólyom, nagyon sok időt tölt a levegőben. (28b)

Az appozíció-jelölő fontos szerepet tölt be a bennfoglalás példáiban, hiszen azt jelzi, hogy a szerkezet tagjai között nem létesíthető olyan predikatív viszony, amelyben az értelmezett szóról állítunk valamit az értelmező segítségével (41). 
Még egy fontos különbséget lehet kiemelni a bennfoglalás és a másik két osztály (az azonosítás és a tulajdonítás) között. Míg az előbbi csoportba tartozó példák átalakíthatóak olyan mondatokká, amelyekben nem kötelező az értelmezett szó és az értelmező szomszédossága (42), addig a tulajdonítás (43a-b) és az azonosítás példáiról (43c-d) ez nem mondható el. Ha egy-egy példa mégis jól formált, akkor nagyon erős intonációval (írásban kettősponttal jelöltem), utógondolatként, gyakran a mégpedig, vagyis kötőszók előfordulása esetén jelenhet meg az értelmező az értelmezett szótól távolabbra (43e-g).

(42) a. Blanka néhány babával játszott, köztük a Gyöngyhercegnövel. (27b)

b. A ragadozó madarak, éles karmokkal bírnak, különösen/például a sasok. (28a)

c. A sólyom nagyon sok idöt tölt a levegöben, de különösen a kabasólyom. (28b)

(43) a. *Egy tandem kerékpár mindig jól jöhet a szerelmeseknek, egy kétüléses bicikli. (25b)

b. *Az orrszarvút a kihalás veszélye fenyegeti, a dél-afrikai vadorzók áldozatát. (26a)

c. *Mari babája megsérült, a nagymamájától kapott játék. (22e)

d. *A világ legnagyobb hatalmú férfija a Fehér Házban él, az USA elnöke. (23c)

e. Az év tanárát a diákok választják meg: (mégpedig) egy lelkes és kiváló pedagógust. (25c)

f. A Louvre-t évente több százezren látogatják: *(vagyis) Európa legnépszerübb múzeumát. (26g)

g. A tanárunk az év madaráról tartott előadást: (vagyis) a túzokról. (23a')

Ez megerősíti azt az elképzelést, hogy a bennfoglalás esetében két tagmondat koordinációja és ellipszis történik, azzal a különbséggel, hogy a (42)-es példákban csak a második tagmondatból kell elliptálni a redundáns elemeket, míg ha az értelmezős szerkezet tagjai szomszédosak egymással, akkor az első tagmondatban (is) történik ellipszis. 


\subsubsection{Az azonosító értelmező különféle csoportjai}

Ebben az alrészben az azonosító értelmezőn belül megkülönböztetett altípusokat próbálom meg elhelyezni egy táblázatban, amelynek célja, hogy egy áttekinthetőbb rendszer létrehozásával minél pontosabb szerkezeti elemzést lehessen nyújtani.

Fontosnak tartom megjegyezni, hogy Heringa (2012) háromféle szemantikai osztálya közül az azonosítás és a tulajdonítás megfeleltethető az Ott (2014)-féle csoportosításnak. Ha megvizsgáljuk az azonosításra hozott magyar példákat (22-24), láthatjuk, hogy mindegyik megfelel a specifikációs értelmező fogalmának, míg a tulajdonítás magyar példái (25-26) a predikációs értelmezővel állíthatók párhuzamba. Természetesen ez nem a véletlen műve, hanem azzal magyarázható, hogy a predikációs értelmező valamilyen tulajdonságot rendel az értelmezetthez (vagyis megfelel a tulajdonítás fogalmának), míg a specifikációs értelmező azonosít két entitást (azaz lefedi az azonosítás fogalmát). Mindez annak köszönhető, hogy Ott (2014) osztályozása a Heringa (2012)-féle szemantikai csoportokra épül. A bennfoglalás példáinak hiányát az Ott (2014)-féle csoportosításból részben azzal is magyarázhatjuk, hogy már Heringa is kizárta ezt a szemantikai osztályt a részletesebb vizsgálatok köréböl.

A szoros értelmezők példái a magyar nyelvben egy szükebb csoportot képeznek, mint a nemzetközi szakirodalomban fellelhető adatok. A magyar példák mindegyike a tulajdonítás szemantikai osztálya alá sorolható be.

11. táblázat: Az azonositó értelmezö fajtái

\begin{tabular}{|l|c|c|}
\hline & Laza értelmezö & Szoros értelmezö \\
\hline Azonosítás & $(44 \mathrm{a})$ & - \\
\hline Tulajdonítás & $(44 \mathrm{~b})$ & $(45)$ \\
\hline Bennfoglalás & $(44 \mathrm{c})$ & - \\
\hline
\end{tabular}

(44) a. A legjobb barátom, János tegnap este meglátogatott a kórházban.

b. Rúzsa Magdi, egy híres énekesnö lett a zsüri negyedik tagja.

c. Három rokonom, köztük a nagymamám elfogadta a meghívást.

(45) Miltiadészt a pápát sokkal kevesebben ismerik Miltiadésznál a hadvezérnél.

A (44a) adatban található értelmező egyben a specifikációs értelmezőre egy példa, míg a (44b)-ben látható appozíciós szerkezet a predikációs értelmezőnek felel meg. 


\subsection{Appozíció-jelölők az értelmezős szerkezetben}

Mint már korábban említettem, a hagyományos leíró nyelvtanok egyes kötőszók ( $a z a z, v a$ gyis, tehát) megjelenése esetén a példákat a kifejtő magyarázó mellérendelés alá sorolják, és nem tekintik értelmezős szerkezetnek. Simonyi (1913), Károly (1958) és Balogh (2004) több olyan példát is megad az értelmezös szerkezetek között, amelyekben kötőszó szerepel. A teljesség igénye nélkül bemutatok néhány példát (a magyar szakirodalmi háttér ismertetésekor több adat is szerepel mindhárom nyelvésztől). A (46a-b) Károlytól, míg a (46c-e) példák Balogh (2004: 76)-ból származnak.

a. A tésztát, föleg a krumplistésztát szerették. [Illyés]

b. Azok meg, mármint az asszonyok, mindegyiket dícsérik. [Veres Péter]

c. Egész nap csak énekeltek, táncoltak, vagyis mulattak.

d. a megye területein, föleg a városokban

f. Az ELTE BTK magyar tanszékei Budapesten, (mégpedig) az Astoriánál vannak.

Mindenképpen amellett kell állást foglalnunk, hogy a magyar nyelv esetében is értelmezös szerkezetet kapunk, ha egyes kötőszók azonos referenciával rendelkező elemek között jelennek meg, olyan konstrukciót alkotva, amelyben a második szerkezettag pontosítja, kiegészíti az első jelentését. Tehát a kötőszó - a továbbiakban appozíció-jelölő - jelenléte nem von maga után automatikusan mellérendelő szerkezetet, amelyet a leíró nyelvtanok a magyarázókifejtő mellérendelések közé soroltak.

Vizsgáljuk meg közelebbről azokat az appozíció-jelölőket, amelyek megjelenhetnek a magyar értelmezős szerkezetben. Az 3.2.2 pont alatti részben hozott példák a háromféle értelmezős szerkezetre (azonosítás, tulajdonítás, bennfoglalás) tartalmazzák az adott csoportra leginkább jellemző appozíció-jelölőket. Az angol, a német és a holland példákkal egybevetve azonban a magyar adatok esetében nem lehet élesen elkülöníteni az egyes appozíció-jelölőket azzal a kikötéssel, hogy az értelmezös szerkezetnek csak egy adott szemantikai osztályára jellemzőek.

Az azonosítás szemantikai osztályát jellemző appozíció-jelölők a következők: vagyis, azaz, mégpedig, érthetöbben mondva, pontosabban kifejezve.

A tulajdonítás szemantikai osztályába tartozó értelmezős szerkezetben a következő appozíciójelölők jelenhetnek meg: tudvalevőleg, mellesleg, amint tudod, mint köztudott.

A bennfoglalás csoportjába tartozó szerkezetekben az alábbi appozíció-jelölőkkel találkozhatunk: köztük, (mint) például, beleértve, úgymint, de föként, de különösen, de leginkább, de 
legfóképpen. Az azonosítás egyes appozíció-jelölői azonban (mint a vagyis, azaz, mégpedig) a tulajdonítás osztályába sorolt egyes példákban is megjelenhetnek, vagyis az appozíció-jelölök alapján nem lehet minden esetben megkülönböztetni az egyes szemantikai osztályokba sorolható adatokat a magyar nyelvben.

\subsection{Egyeztetés az azonosító értelmezővel}

Ahhoz, hogy az azonosító értelmezőhöz a megfelelő szerkezetet tudjuk rendelni, az szükséges, hogy eldöntsük a több évtizede tartó vitát: alá- vagy mellérendelés történik a konstrukcióban, vagy valamiféle ellipszissel állunk szemben. A kérdés megválaszolásában segíthet annak vizsgálata, hogy az alanyi vagy tárgyi szerepben megjelenő értelmezős szerkezettel hogyan egyeztetjük az állítmányt.

Balogh (2004: 71) két példát megemlítve amellett érvel, hogy bizonyos esetekben az alany (47a), illetve a tárgy értelmezője (47b) irányítja az állítmánnyal való egyeztetést.

a. Ági és Panni, az újonnan jött osztálytársak hamarosan beilleszkedtek az osztályközösségbe.

b. Két diákot, Nagy Jóskát és Kis Pistát behívatták az igazgatói irodába.

A (47a) példa esetében akár az értelmezett szó is kiválthatná a többes számú egyeztetést, mivel az és-koordináció esetében a preverbális pozícióban megjelenő egyes számú alanyok koordinációja eredményezhet többes számú állítmányt is (48), ahogyan É. Kiss (2012:1026) ezt megmutatta.

\section{Anna és Péter tegnap megérkeztek.}

A vizsgálatot kiterjesztettem több adatra is, amelyek esetében nem született egyértelmü grammatikalitási ítélet, ezért döntöttem ezen példamondatok tesztelése mellett.

\subsubsection{A tesztek rövid ismertetése}

Annak a kérdésnek az eldöntéséhez, hogy vajon alárendelésként vagy mellérendelésként viselkedik-e a kérdéses konstrukció, az értelmezős szerkezetet tartalmazó mondatokat az egyeztetés alakulását tekintve teszteltem. Egyrészt az alanyi pozícióban álló értelmezős szerkezetet 
vizsgáltam, amelyben az értelmezett szó és az értelmező külön-külön megjelenve eltérő egyeztetést vált ki az állítmányon. Másrészt a tárgyi szerepet betöltő értelmezős konstrukciót is teszteltem, amelyben a szerkezettagok eltérő határozottságúak. A tesztelést két körben végeztem el. Az első esetben olyan tesztet állítottam össze, amelybe semleges, úgynevezett kontrollmondatok is bekerültek. Kilenc kérdőívet kaptam vissza, melynek kitöltői között egyaránt voltak nyelvészek és nem nyelvészek is. A második körben célirányosan már csak azokat a mondatokat teszteltem kizárólag nyelvészek körében, amelyeknek a grammatikalitási megítélése ingadozó volt az első teszteléskor. Ebben az esetben nyolc kérdőív válaszait dolgozhattam fel. A tesztek a mellékletben találhatók. Fontos azonban ezen a ponton kiemelni, hogy a példamondatok kapcsán az egyik instrukció az volt, hogy csak a vesszőnél szabad szünetet tartani. Ennek azért van nagy jelentősége, mert az ettől eltérő intonáció befolyásolhatja az eredményt. Ha megvizsgáljuk a teszt példamondatait, akkor láthatjuk, hogy csak az értelmezett szó és az értelmező között kellett intonációs szünetet tartani.

A tesztelés során megpróbáltam több változót is figyelembe venni, ezek a következők voltak: Vajon befolyásolja-e az eredményeket, hogy az értelmezős szerkezet fókusz- vagy topikpozícióban jelenik meg? Vajon hatással van-e a grammatikalitási ítéletekre az ige fajtája? Változik-e a mondatok megítélése, ha az ige távolabbra kerül az értelmezős szerkezettől?

\subsubsection{A tesztelés eredményei}

Az eredményeket a 12. táblázat foglalja össze. Beszíneztem azokat a sorokat, amelyek csak az első tesztben megjelenő példamondatokat tartalmazzák - ezeknél láthatjuk, hogy egyértelmű értékítélet született az adatok grammatikalitását illetően.

12. táblázat: A tesztelés eredménye

\begin{tabular}{|c|c|c|c|}
\hline \multicolumn{1}{|c|}{ Példamondatok } & $\checkmark$ & $? / ? ?$ & $*$ \\
\hline \multicolumn{1}{|c|}{ Alany-állitmány egyeztetése preverbális pozícióban megjelenö értelmezö esetén } \\
\hline 1. Anna és Éva, a két lányom megérkeztek. & 10 & 1 & 6 \\
\hline 2. Anna és Éva, a két lányom megérkezett. & 8 & 0 & 1 \\
\hline 3. A két lányom, Anna és Éva megérkeztek. & 9 & 0 & 0 \\
\hline 4. A két lányom, Anna és Éva megérkezett. & 8 & 1 & 0 \\
\hline 5. Anna és Éva, a két lányom összevesztek. & 9 & $2+1$ & 5 \\
\hline 6. Anna és Éva, a két lányom összeveszett. & 9 & 0 & 0 \\
\hline
\end{tabular}




\begin{tabular}{|c|c|c|c|}
\hline 7. A két lányom, Anna és Éva összevesztek. & 9 & 0 & 0 \\
\hline 8. A két lányom, Anna és Éva összeveszett. & 8 & 0 & 1 \\
\hline 9. Anna és Éva, a két lányom tegnap megérkeztek. & 7 & 3 & 7 \\
\hline 10. Anna és Éva, a két lányom tegnap megérkezett. & 8 & 0 & 1 \\
\hline 11. A két lányom, Anna és Éva tegnap megérkeztek. & 8 & 0 & 1 \\
\hline 12. A két lányom, Anna és Éva tegnap megérkezett. & 9 & 0 & 0 \\
\hline 13. A lányaim, a két barátnőd megérkezett. & 5 & 4 & 8 \\
\hline 14. A lányaim, a két barátnőd megérkeztek. & 6 & 7 & 4 \\
\hline 15. A két barátnőd, a lányaim megérkezett. & 0 & 0 & 9 \\
\hline 16. A két barátnőd, a lányaim megérkeztek. & 12 & 2 & 3 \\
\hline 17. A lányaim, a két barátnőd tegnap megérkezett. & 8 & 1 & 8 \\
\hline 18. A lányaim, a két barátnőd tegnap megérkeztek. & 8 & 6 & 3 \\
\hline 19. A két barátnőd, a lányaim tegnap megérkezett. & 0 & 0 & 9 \\
\hline 20. A két barátnőd, a lányaim tegnap megérkeztek. & 9 & 3 & 5 \\
\hline 21. Anna és Éva, a két lányom vesztek össze. & 9 & 5 & 3 \\
\hline 22. Anna és Éva, a két lányom veszett össze. & 9 & 0 & 0 \\
\hline 23. A két lányom, Anna és Éva veszett össze. & 9 & 0 & 0 \\
\hline 24. A két lányom, Anna és Éva vesztek össze. & 8 & 0 & 1 \\
\hline 25. A lányaim, a két barátnőd veszett össze. & 8 & 3 & 6 \\
\hline 26. A lányaim, a két barátnőd vesztek össze. & 7 & $4+1$ & 5 \\
\hline 27. A két barátnőd, a lányaim veszett össze. & 0 & 0 & 9 \\
\hline 28. A két barátnőd, a lányaim vesztek össze. & 8 & 1 & 0 \\
\hline \multicolumn{4}{|c|}{ Alany-állitmány egyeztetése posztverbális pozícióban megjelenö értelmezö esetében } \\
\hline 29. Összevesztek Anna és Éva, a két lányom. & 9 & 2 & 6 \\
\hline 30. Összeveszett Anna és Éva, a két lányom. & 9 & 0 & 0 \\
\hline 31. Összevesztek a két lányom, Anna és Éva. & 1 & 0 & 8 \\
\hline 32. Összeveszett a két lányom, Anna és Éva. & 9 & 0 & 0 \\
\hline 33. Összevesztek a lányaim, a két barátnőd. & 9 & 0 & 0 \\
\hline 34. Összeveszett a lányaim, a két barátnőd. & 0 & 0 & 9 \\
\hline 35. Összevesztek a két barátnőd, a lányaim. & 1 & 0 & 8 \\
\hline 36. Összeveszett a két barátnőd, a lányaim. & 9 & 6 & 2 \\
\hline
\end{tabular}




\begin{tabular}{|l|c|c|c|}
\hline \multicolumn{4}{|l|}{ Tárgy-állítmány egyeztetése preverbális pozícióban megjelenö értelmezö esetén } \\
\hline 37. Annát, egy bájos kislányt felkértek a fotózásra. & 7 & 5 & 5 \\
\hline 38. Annát, egy bájos kislányt felkérték a fotózásra. & 10 & 4 & 3 \\
\hline 39. Egy bájos kislányt, Annát felkértek a fotózásra. & 3 & 3 & 11 \\
\hline 40. Egy bájos kislányt, Annát felkérték a fotózásra & 15 & 0 & 2 \\
\hline 41. Annát, egy bájos kislányt kértek fel a fotózásra. & 4 & 7 & 6 \\
\hline 42. Annát, egy bájos kislányt kérték fel a fotózásra. & 11 & 1 & 5 \\
\hline 43. Egy bájos kislányt, Annát kértek fel a fotózásra. & 3 & 2 & 12 \\
\hline 44. Egy bájos kislányt, Annát kérték fel a fotózásra. & 16 & 1 & 0 \\
\hline Tárgy-állítmány egyeztetése posztverbális pozícióban megjelenö értelmezö esetén \\
\hline 45. Felkértek Annát, egy bájos kislányt a fotózásra. & 0 & 0 & 9 \\
\hline 46. Felkérték Annát, egy bájos kislányt a fotózásra. & 8 & 0 & 1 \\
\hline 47. Felkértek egy bájos kislányt, Annát a fotózásra. & 9 & 0 & 0 \\
\hline 48. Felkérték egy bájos kislányt, Annát a fotózásra. & 0 & 1 & 8 \\
\hline
\end{tabular}

\subsubsection{Az eredmények kiértékelése}

Általánosságban elmondható, hogy a mondatok megítélésében nem mutatkozott szignifikáns eltérés annak függvényében, hogy az értelmezős szerkezet topik- vagy fókuszpozícióban jelent-e meg a mondatban, illetve hogy milyen az ige fajtája (kollektív vagy sem). Abban az esetben, amikor az értelmezős szerkezet és az állítmány távolabbra került egymástól, kimutatható némi változás a mondatok megítélésében, de ezek a különbségek nem ugyanabba az irányba mutatnak (erre még ki fogok térni részletesebben a 3.4.3.1 pont alatt).

\subsubsection{Az alanyi értelmezős szerkezet és az állítmány egyeztetése}

Először nézzük meg, milyen eredmények születtek a preverbális pozícióban megjelenő alanyi értelmezős szerkezetek esetében, amelyek topik szerepét töltik be a mondatban.

Az első 12 példamondat kevésbé perdöntő a tesztelés szempontjából, mivel egy éskoordináció jelenik meg az értelmezős szerkezet egyik tagjaként. É. Kiss (2012) alapján tudjuk, hogy a preverbális pozícióban megjelenő egyes számú főnévi csoportok koordinálása egyes és többes számú egyeztetést is kiválthat az állítmányon. Ebből adódóan egyes monda- 
tok $(2,4,6,8,10,12)^{40}$ esetében nem lehet egyértelműen eldönteni, hogy az értelmezős szerkezet melyik tagja váltotta ki az egyes számot az állítmányon. Az igazi cél ezeknél az adatoknál az volt, hogy többes számú ige megjelenése esetében el tudjuk dönteni, hogy az értelmező vagy az értelmezett szó váltja ki a többes számú egyeztetést. Amikor az éskoordináció értelmezőként állt egy többes számú ige mellett, akkor egyértelmü grammatikalitási ítéletek születtek: az adatokat grammatikusnak tartották a kérdőív kitöltői. Amikor azonban az és-koordináció értelmezettként szerepelt a mondatokban többes számú igével, már nagymértékű ingadozás volt tapasztalható az adatok megítélésében, de többen voltak azok, akik grammatikusnak vagy kérdőjelesnek ítélték ezeket a tesztmondatokat, mint azok, akik agrammatikusnak. Ezen adatok alapján nem lehet egyértelműen állást foglalni, hogy az értelmező vagy az értelmezett irányítja az állítmánnyal való egyeztetést alanyi pozícióban megjelenő appozíciós szerkezet esetében.

Érdekes még megvizsgálni azt, hogy mi történik, ha az értelmezős szerkezet és az állítmány közé beékelődik egy újabb elem. A kiinduló hipotézis az, hogy a távolság felerősíti a közelségi elv hatását, és az értelmezővel való egyeztetés irányába fognak mutatni a grammatikalitási ítélek. A minimálpárokat megvizsgálva látható, hogy azokban az adatokban, amelyekben egyértelmű volt a grammatikalitási ítélet a tegnap határozó megjelenése előtt, nem történt változás a mondat megítélését tekintve az után sem, hogy az értelmezős szerkezettől távolabbra került az állítmány (2-es és 10-es, 3-as és 11-es, 4-es és 12-es minimálpárok). Az 1-es (10:1:6) és a 9-es (7:3:7) minimálpár esetében (amelyben az és-koordinációs értelmezett szó mellett többes számú ige jelenik meg) a határozónak az appozíció és az állítmány közé való beékelődésekor csökkent azok száma, akik grammatikusnak ítélték a példamondatot - alátámasztva ezzel a kiinduló hipotézisemet.

Nézzük meg a többi mondatot (a 13 -astól a 20-asig), amelyekben olyan főnévi csoportok találhatók az értelmezős szerkezetben, amelyek külön-külön megjelenve eltérő egyeztetést váltanak ki az igével. Egyértelmü grammatikalitási ítélet csak a következő esetben született: ha többes számú értelmező mellett egyes számú állítmány jelent meg, akkor minden adatközlő agrammatikusnak ítélte a példát (15, 19). Kevesebben találták agrammatikusnak, ha többes számú értelmezett szó mellett többes számú ige jelent meg egyes számú helyett (13-as és 14 es, illetve 17-es és 18-as minimálpárok). Ha az értelmező volt többes számú, akkor az egyes számú igét tartalmazó mondatot mindenki agrammatikusnak ítélte (15-ös és 19-es adatok),

\footnotetext{
${ }^{40}$ A teszt példamondataira bekeretezett arab számokkal fogok hivatkozni, hogy meg lehessen őket különböztetni a disszertációban szereplő többi adattól.
} 
míg többes számú ige (16-os és 20-as adatok) megjelenése esetén nem született egységes grammatikalitási ítélet, bár többen voltak azok, akik jól formáltnak tartották az ilyen típusú mondatokat, mint akik nem.

Érdekes eredmény figyelhető meg, amikor egy határozó bekerül az appozíciós szerkezet és az állítmány közé: Többes számú értelmezett szó esetében az egyes (13-as és 17-es minimálpár) és a többes számú igét (14-es és 18-as minimálpár) tartalmazó mondatokat egyaránt többen ítélték jól formáltnak a tegnap határozó megjelenésekor, miközben a rosszulformáltsági érték változatlan maradt. A többes számú értelmezőt és egyes számú igét tartalmazó minimálpár (15-ös és 19-es) mindkét tagját egyaránt egységesen mindenki agrammatikusnak ítélte. Ugyanakkor az eddigieknek ellentmondó eredmény született a 16-os és a 20-as minimálpárt tekintve, ahol a többes számú értelmező mellett megjelenő többes számú ige esetében a határozó megjelenését követően csökkent azoknak a száma, akik jól formáltnak ítélték a mondatot.

Az alábbiakban azokat a példákat (21-estöl a 28-asig) veszem sorra, amelyekben az értelmezős szerkezet fókuszként jelenik meg. Az és-koordinációt tartalmazó adatok ebben az esetben is kevésbé fontosak. Egyértelmü grammatikalitási ítéletek születtek: ha az éskoordináció az értelmező volt, akkor az egyes (23-as adat) és a többes számú igét (24-es adat) tartalmazó mondat egyaránt grammatikus az adatközlök szerint. Csak akkor nem született egyöntetü ítélet, amikor az és-koordináció értelmezett szóként jelent meg egy többes számú ige mellett (21-es példa), de többen találták jól formáltnak a szóban forgó adatot, mint rosszul formáltnak. Egyértelmű grammatikalitási ítélet született a többes számú értelmezőt tartalmazó mondatok esetében: egyes számú igével agrammatikusnak (27-es), míg többes számú igével jól formáltnak (28-as) ítélték az adatokat. A többes számú értelmezett szó mellett mind az egyes számú, mind a többes számú ige megjelenése esetében nagy szóródás mutatkozott a mondatok megítélésében (25-ös és 26-os példák).

A következőkben a posztverbális pozícióban álló értelmezős szerkezetet tartalmazó mondatok (a 29-estől a 36-osig) grammatikalitási ítéleteit fogom kiértékelni. Az adatok többségének (a 30-astól a 35-ösig) a megítélése arra utal, hogy az egyeztetést az értelmezett szó irányítja. A 29-es adathoz kapcsolódó grammatikalitási ítélet azért meglepő, mert É. Kiss (2012) szerint posztverbális pozícióban megjelenő egyes számú főnévi csoportok éskoordinációja esetében agrammatikus mondatot eredményez a többes számú ige. Ennek ellenére az Összevesztek Anna és Éva, a két lányom mondatot 9:2:6 arányban a többség gramma- 
tikusnak ítélte. Az elvárásokkal ellentétben a 36-os adat esetében sem született egyöntetű ítélet, amire nincs kielégítő magyarázat.

Az fentieket figyelembe véve tehát az a konklúzió vonható le, hogy az eredmények alapján nem lehet egyértelműen állást foglalni amellett, hogy az értelmezett szóval vagy az értelmezővel történik az egyeztetés, ugyanis két tényező alakítja egyszerre az egyeztetés alakulását: a közelségi elv és a jelölt jegyérték a többességet illetően. Az egyes számú egyeztetést kiváltó főnévi csoport (morfológiailag) jelöletlen jegyértékkel bír, míg a többes számú egyeztetéssel járó főnévi csoport (morfológiailag) jelölt jegyértéket hordoz (Greenberg 1966, Corbett 2000). ${ }^{41} \mathrm{Ha}$ az értelmező többes számú, akkor egyértelmű az egyeztetés alakulása: többes számú ige (49) jelenik meg (a közelségi elv is a többes számú állítmányt erősíti meg).
a. A két barátnőd, a lányaim megérkeztek / érkeztek meg.
b. *A két barátnöd, a lányaim megérkezett / érkezett meg.

Ha az értelmezett szó a többes számú, akkor a preverbális pozícióban megjelenő értelmezős szerkezet esetében a közelségi elv és a többességi jelölt jegyérték szembekerül egymással, és a mondatok grammatikalitásának megítélése igen vegyes képet mutat az egyeztetés alakulását illetően (50).
a. ?? A lányaim, a két barátnöd megérkezett / veszett össze.
b. ? A lányaim, a két barátnöd megérkeztek/vesztek össze.

Ha az értelmezős szerkezet posztverbális pozícióban jelenik meg, akkor a közelségi elv az irányadó az egyeztetés alakulását tekintve (51).
a. Összevesztek / *összeveszett a lányaim, a két barátnöd.
b. Összeveszett / * összevesztek a két barátnőd, a lányaim.

\footnotetext{
${ }^{41}$ A morfológiai jelöltség mellett beszélhetünk szemantikai jelöltségről is: nemcsak a többes számú főnévi csoportok rendelkeznek jelölt jegyértékkel a többességet illetően, hanem a szemantikailag többes számú DP-k is (Farkas-De Swart 2010). Mivel a magyar nyelvben a szemantikailag többes számú, de morfológiailag egyes számú DP-k az állítmányon egyes számú egyeztetést váltanak ki (Három / sok / több gyerek összegyült.), a morfológailag jelölt és jelöletlen jegyértékkel dolgozom a disszertációban. Ugyanakkor az egyes számú főnévi csoportok koordinációja is viselheti a jelöltséget, ha többes számú egyeztetést vált ki (Mari és Anna megérkeztek).
} 


\subsubsection{A tárgy és az állítmány egyeztetése}

Először a preverbális pozícióban megjelenő tárgyi értelmezős szerkezetet tartalmazó mondatok (a 37-estől a 44-esig) grammatikalitási ítéleteit vizsgálom meg. Egyértelmü ítélet csak két esetben (40-es és 44-es adat) született, amikor az értelmező határozott főnévi csoport volt, és határozott tárgyi szuffixumot viselő predikátum jelent meg a mondatban, grammatikusnak ítélték a példákat. A válaszadók kétharmada agrammatikusnak ítélte azokat a példákat (39-es és 43-as), amelyekben határozott értelmező mellett általános ragozású ige állt. ${ }^{42}$ Amikor az értelmezett szó volt határozott főnévi csoport, abban az esetben már igen vegyes képet mutat az adatok megítélése, de a preferált változat a határozott tárgyi ragozás volt.

A posztverbális pozícióban megjelenő tárgyi értelmezős szerkezetek esetében egyértelmủ grammatikalitási ítéletek születtek: Agrammatikusnak ítélték az adatközlők azokat az adatokat, amelyekben általános ragozású ige állt határozott értelmezett szó mellett, vagy határozott ragozású predikátum szerepelt határozatlan értelmezett szó mellett. Azokat a szerkezeteket tartották jól formáltnak, amelyekben határozott tárgyi szuffixumot viselő ige után határozott értelmezett szó, vagy általános ragozású predikátum után határozatlan értelmezett szó szerepelt.

Konklúzió: A preverbális pozícióban megjelenő tárgyi értelmezős szerkezet esetében is két tényező van hatással az egyeztetésre: a közelségi elv és a jelölt jegyérték a határozottságot tekintve. A határozatlan főnévi csoport jelöletlen, míg a határozott főnévi csoport jelölt jegyértékkel bír. Ha az értelmező a határozott, akkor egyértelműen a határozott ragozás a preferált a mondatok megítélésekor (52).
a. *Egy bájos kislányt, Annát felkértek / kértek fel a fotózásra.
b. Egy bájos kislányt, Annát felkérték / kérték fel a fotózásra.

Ha a közelségi elv és a jelölt jegyérték konfliktusba kerül egymással, akkor már vegyes képet mutat a mondatok megítélése, de a határozott ragozás tünik preferáltabbnak (53).
a. ?? Annát, egy bájos kislányt felkértek / kértek fel a fotózásra.
b. ? Annát, egy bájos kislányt felkérték / kérték fel a fotózásra.

\footnotetext{
${ }^{42}$ A magyar szakirodalomban a tárgyas ragozás két változatára több terminuspár is használatban van, a disszertációmban az általános-határozott (Magyar grammatika 2000) szakszavakat használom - leginkább a szóismétlés elkerülése végett választva ezt a megkülönböztetést.
} 
A posztverbális pozícióban álló értelmezős szerkezetet tartalmazó mondatok esetében egyértelmủ grammatikalitási ítéletek születtek: ilyenkor a közelségi elv alapján történik az egyeztetés (54).
a. *Felkértek Annát, egy bájos kislányt a fotózásra.
b. Felkérték Annát, egy bájos kislányt a fotózásra.
c. *Felkérték egy bájos kislányt, Annát a fotózásra.
d. Felkértek egy bájos kislányt, Annát a fotózásra.

A teszteredmények kiértékelésének összegzéseként elmondható, hogy a közelségi elvnek is van szerepe az egyeztetés alakulásában, ami arra utalhatna, hogy mellérendelő szerkezettel állunk szemben, de a jelölt jegyérték olykor ezt felülírja, és ilyenkor az értelmezett szóval történik az egyeztetés, ez pedig az alárendelés irányába mutat.

Továbbá érdemes megemlíteni, hogy a kapott eredmények alátámasztják Gécseg (2012) által végzett kérdőíves felmérés egyik konklúzióját. Gécseg (2012) arra a kérdésre keresi a választ, hogyan azonosítható a magyarban a kopulás mondatok alanya. Jelen disszertáció eredményei is összhangban vannak az alábbi következtésével: a 3. személyü NP-kkel való számbeli egyeztetéskor kimutatható egy olyan tendencia, mely szerint a morfológiailag jelölt alakú (vagyis a többes számú) NP-vel való egyeztetést részesítik előnyben az adatközlők.

\subsubsection{Az intonációs szünet jelentősége}

Az eddigi megfigyeléseket azonban módosítja - amint már fentebb is említettem -, ha az értelmező után is tartunk intonációs szünetet. Ezzel a szerkezet közbevetéses jellegét erősítjük fel, aminek köszönhetően úgy tűnik, az állítmányt már inkább az értelmezett szóval kell egyeztetni a preverbális pozícióban megjelenő alanyi (55a-b) vagy tárgyi appozíciós szerkezet $(55 \mathrm{c}-\mathrm{d})$ esetén is.

(55) a. A lányaim, a két barátnőd, összevesztek.

b. A két barátnöd, a lányaim, összeveszett.

c. Annát, egy bájos kislányt, felkérték a fotózásra.

d. Egy bájos kislányt, Annát, felkértek a fotózásra. 
A fenti példák azt mutatják, hogy az értelmező után tartott intonációs szünet esetében a preverbális pozícióban megjelenő alanyi vagy tárgyi appozíciós szerkezetnek az első tagja, vagyis az értelmezett szó irányítja az állítmánnyal való egyeztetést.

Ugyanakkor mindenképpen ki kell emelni, hogy ha az értelmezős szerkezet fókuszpozícióban jelenik meg, az értelmező után nem tarthatunk intonációs szünetet, mivel az ige előtt leesik a fókuszhangsúly, míg intonációs szünet esetén fel kell emelni a hangsúlyt (56).

(56) a. *A lányaim, a két barátnőd, vesztek össze.

b. *A két barátnöd, a lányaim, veszett össze.

c. *Annát, egy bájos kislányt, kérték fel a fotózásra.

d. *Egy bájos kislányt, Annát, kértek fel a fotózásra.

Mivel az intonációs szünet igen fontos szerepet kap egy-egy adat grammatikalitásának megítélésekor, a további tervek között szerepel egy olyan tesztsor összeállítása, amelyben a példamondatok felvételröl hangzanak el.

\subsubsection{Egyeztetés a specifikációs és a predikációs értelmezővel}

A következőkben vizsgáljuk meg azt, hogy az állítmánnyal való egyeztetést befolyásolja-e, hogy predikációs (57a) vagy specifikációs értelmezős szerkezet (57b) jelenik meg alanyi, illetve tárgyi szerepben.

a. Nagy Tamást, egy híres festőt ?kérték fel / ??kértek fel a fotózásra.

b. Egy híres festöt, Nagy Tamást kérték fel a fotózásra.

Nem meglepő, hogy ugyanazt az eredményt kapjuk, mint a tesztelt mondatoknál (52-53), ahol szintén megtalálható a példák között a kétféle appozíciós szerkezet. A predikációs appozíció esetében nem dönthető el egyértelmủen, hogy melyik szerkezettaggal kell egyeztetni az állítmányt a határozottság tekintetében, mivel konfliktusba kerül egymással a közelségi elv és a jelölt jegyérték. A specifikációs appozíció esetében az állítmány egyeztetését az értelmező irányítja, mivel itt a közelségi elv és a jelölt jegyérték egymást erősítve érvényesül.

A mondathatározó megjelenése az értelmezős szerkezetben már befolyásolni látszik az egyeztetés alakulását. 
(58) a. Rúzsa Magdit, állítólag egy híres énekesnöt választottak / *választották meg zsüritagnak.

b. Egy híres énekesnöt, állítólag Rúzsa Magdit választották / * választottak meg zsüritagnak.

c. Kiss Katát, valószínüleg egy leendö szépségkirálynöt hívnak / *hívják meg a müsorba.

d. Egy leendö szépségkirálynöt, valószínüleg Kiss Katát hívják / *hívnak meg a müsorba.

(59) a. Megválasztották zsüritagnak Rúzsa Magdit, állítólag egy híres énekesnöt.

b. Megválasztottak zsüritagnak egy híres énekesnöt, állítólag Rúzsa Magdit.

c. Meghívják a müsorba Kiss Katát, valószínüleg egy leendö szépségkirálynőt.

d. Meghívnak a müsorba egy leendö szépségkirálynőt, valószínüleg Kiss Katát.

A példák alapján azt láthatjuk, hogy a mondathatározók jelenlétének köszönhetően eltünik a korábbi bizonytalanság az egyeztetést illetően, és már csak a közelségi elv befolyásolja az állítmányon megjelenő szuffixumot mind a preverbális (58), mind a posztverbális pozícióban (59) megjelenő appozíció esetében.

A posztverbális pozícióban megjelenő, mondathatározót tartalmazó értelmezős szerkezetben még inkább megragadható a nyelvi intuíciónk számára a predikációs és a specifikációs appozíció közti különbség. (59a)-ban a predikációs értelmező azt a jelentést hívja elö, hogy Rúzsa Magdi állítólag egy híres énekesnö. Ezzel szemben (59b)-ben a specifikációs értelmező elsődlegesen azt a jelentést vonja maga után, hogy állítólag Rúzsa Magdit választották meg zsüritagnak.

\subsection{Az azonosító értelmező elemzése}

Az azonosító értelmező esetében egyetlen érv szól a szerkezet tagjai közti alárendelés feltételezése mellett - a két elem között predikatív viszony létesíthető -, de ennél több érv nem hozható fel. A szerkezet nem elemezhető - legalábbis nem minden esetben - két tagmondat koordinációjaként és ellipszisként, mert ily módon nem tudnánk magyarázatot adni az egyeztetés alakulására az alábbi példában (60), ahol az állítmányt az értelmezővel kellene egyeztetni ellipszis esetében.

(60) Én, a koronatanú pontosan jelentem meg a bíróságon. 
Az azonosító értelmező viselkedése leginkább a mellérendelésekével állítható párhuzamba, ugyanakkor van köztük egy fontos különbség. Az appozíciós szerkezet esetében két azonos, míg mellérendelésnél két eltérő referenciájú entitás (vagy cselekvés) jelenik meg a konstrukcióban. További különbség, hogy többszörös mellérendelés esetén az utolsó mellérendelt tag előtt ki kell tenni a kötőszót (61a), míg ha az appozíciós szerkezetben jelenik meg több értelmező, a szerkezet appozíció-jelölő nélkül is grammatikus lesz (61b).

(61) a. Vettem két szoknyát, egy nadrágot és három blúzt.

b. Meglátogatott Mari, a szomszédom, a város legjobb fogorvosa.

Az elemzés kidolgozása során három lehetséges megközelítést is el kellett vetnem: egyrészt az appozíciós szerkezet lecsökkentett vonatkozói tagmondatként való felfogását, másrészt ellipszisként való elemzését, és végül az értelmezős konstrukciók RELATOR-os elemzését (Den Dikken 2006) a szerkezettagok között lévő predikatív viszonyra építve.

Először is azt mutatom meg, hogy az értelmezős szerkezet lecsökkentett vonatkozói tagmondatként való elemzése miért nem alkalmazható egységesen a magyar példákra. Megismétlem Smith (1964: 42) példáját, amely az angol nyelvben illusztrálja azt, hogy egy értelmezői relatív kopulás tagmondatból a vonatkozó névmás és a kopula törlésével kapható meg egy appozíciós szerkezet (62).

(62) John, (who was) a good salesman, charmed them immediately.

'János, (aki) egy jó eladó (volt), azonnal elbűvölte őket.'

Ezen megoldási javaslat során a következő problémák merültek fel a magyar adatokkal kapcsolatban: Egyrészt a bennfoglalás példáin (63a) kívül néhány, az azonosítás szemantikai osztályába tartozó adat (63b) sem alakítható át értelmezői vonatkozó tagmondattá.

(63) a. *A ragadozó madarak, (különösen azok,) akik a sasok, éles karmokkal bírnak.

b. */??A lányaim, akik a két barátnőd, megérkeztek.

Másrészt nehéz lenne elszámolni a szerkezettagok közti egyezéssel, vagyis hogy miért jelenik meg az értelmezett szó esetragjával megegyező esetvégződés a lecsökkentett értelmezői tagmondaton (64). 
Harmadrészt meg kellene magyarázni azt is, hogy miért és hogyan tűnik el a vonatkozó tagmondat után (65a) kötelezően megjelenő intonációs szünet bizonyos értelmezős szerkezetekből (65b).

a. Annát, aki egy bájos kislány, felkérték a fotózásra.

b. Annát, egy bájos kislányt felkérték a fotózásra.

Végül, de nem utolsósorban az állítmánnyal való egyeztetés sem alakul mindig ugyanúgy a kétféle szerkezetben. Míg a vonatkozói tagmondatot tartalmazó példában a vonatkozás antecedensével történik a mátrix mondat állítmányának az egyeztetése (66a), addig az értelmezős szerkezetet tartalmazó példákban olykor az értelmezővel, és nem az értelmezett szóval kell az állítmányt egyeztetni (66b).

(66) a. Egy bájos kislányt, aki Anna, felkértek a fotózásra.

b. Egy bájos kislányt, Annát *felkértek/felkérték a fotózásra.

A fenti problémákat figyelembe véve arra a következtetésre juthatunk, hogy a magyar értelmezős szerkezetek lecsökkentett vonatkozó tagmondatként való felfogása nem nyújt egy adekvát, egységes elemzést, és több kérdést vet fel, mint amennyit megválaszolna.

Egy másik lehetséges megközelítés az appozíciós szerkezetek ellipszisként való elemzése. Azért érdemes megvizsgálni ezt a lehetőséget, mert így a kétféle értelmezőre (az azonosítóra és a hátravetett jelzőire) egységes elemzést lehetne adni. A bennfoglalás példái esetében Burton-Roberts (1994), Heringa (2012) két tagmondat koordinációját és azokon végrehajtott ellipszist javasol (67).

(67) [CP1 A sólyom nagyon-sok idöt tölt a levegöben], [СР2 de különösen egy kabasólyom nagyon sok időt tölt a levegőben].

Amikor az értelmező után is kell intonációs szünetet tartani, és a mátrix mondat állítmányát az értelmezett szóval kell egyeztetni, nem járható út a tagmondatok koordinációján végrehajtott ellipszis (68b), hanem az értelmezőt tartalmazó tagmondatot be kell ékelni a másik CP-be (68c). 

a. A lányaim, a két barátnőd, megérkeztek.
b. *[ ${ }_{\mathrm{CP} 1}$ A lányaim megérkeztek], [CP2 a két barátnőd megérkezett].
c. [ ${ }_{\mathrm{CP} 1} \mathrm{~A}$ lányaim [ $\mathrm{CP}_{2}$ a két barátnőd megérkezett] megérkeztek].

Ha az értelmező után nincs intonációs szünet, nem egyértelmü, hogy az ellipszist tagmondatok koordinációján vagy közbeékelésén kell alkalmazni. Az állítmánynak a tárgyi értelmezővel való egyeztetése első megközelítésben arra utalt, hogy az azonosítás példáit lehet két tagmondat koordinációjaként elemezni (69a, b), azonban vannak olyan példák, amelyek ennek ellentmondanak (69c, d).

a. Egy bájos kislányt, Annát felkérték/*felkértek a fotózásra.

b. [CP1 Egy bájos kislányt felkértek a fotózásra], [СР2 Annát felkérték a fotózásra].

c. ?A lányaim, a két barátnőd megérkeztek / ?? A lányaim, a két barátnőd megérkezett.

d. [CP1 A lányaim [CP2 a két barátnőd megérkezett] megérkeztek]. / [CP1 A lányaim megérkeztek], [CP2 a két barátnőd megérkezett].

Az ellipszis feltételezése során felmerült több kérdés is: Mi irányítja, befolyásolja - az állítmánnyal való egyeztetésen túl -, hogy a tagmondatok koordinációját vagy közbeékelődését feltételezzük? Hogyan magyarázza meg az ellipszises elemzés, hogy ha az értelmező többes számú alany vagy határozott tárgy, akkor egyértelműen az értelmező, és nem az értelmezett szó irányítja az állítmánnyal való egyeztetést? Mivel ez a megközelítés nem tud támaszkodni a tesztmondatok kiértékelésekor kapott eredményekre, vagyis nem magyarázza a közelségi elv és a jelölt jegyérték együttes müködését, illetve konfliktusát, arra a következtetésre jutottam, hogy egy másik elemzési módot kell kidolgozni, amely nem hagyja figyelmen kívül a disszertáció eredményeit.

Harmadik megoldásként felmerült annak lehetősége, hogy az appozíciós konstrukciókat - hasonlóan a birtokos szerkezethez, a befejezett melléknévi és a határozói igeneves szerkezethez (Szőke 2011) - olyan predikatív viszonyként is lehetne elemezni, amelyben a RELATOR teremt kapcsolatot a két szerkezettag között. Den Dikken (2006) abból a hipotézisből indul ki, hogy minden predikatív viszony szintaktikailag olyan szerkezettel van reprezentálva, amelyben a predikátumot és az alanyt denotáló összetevők egy összekötő elem, vagyis a RELATOR alárendeltjei, amely létrehozza a kapcsolatot - mind a szintaktikait, mind a szemantikait - a két összetevő között. Ezt a fajta elgondolást azért kellett elvetnem - még az elemzések kidol- 
gozása előtt -, mert ahogyan a 3.2.2 pont alatti alfejezetben láthattuk, a bennfoglaló értelmezőkön kívül vannak olyan, az azonosítás és a tulajdonítás szemantikai osztályába tartozó értelmezők is, amelyekben a szerkezettagok között nem hozható létre predikatív viszony. Ez a tény kizárja az egységes elemzés kidolgozásának lehetőségét (még abban az esetben is, ha csak egyes appozíciófajtákra próbáljuk meg alkalmazni).

Amint láttuk a 3.4 pont alatti részben, az egyeztetés alakulása sem nyújt perdöntő bizonyítékot arra nézve, hogy az azonosító értelmezős szerkezet alárendelés vagy mellérendelés. A kérdést tovább bonyolítja az a tény, hogy az azonosító értelmező egyes fajtái más prozódiai, szintaktikai és szemantikai tulajdonságokkal rendelkeznek. Mindezek figyelembevételével az a javaslatom (Szőke megjelenés alatt), hogy az azonosító értelmező egyes fajtáihoz különkülön szerkezeti elemzést kell rendelni az eltérő tulajdonságokra építve.

\subsubsection{Az értelmező utáni intonációs szünet}

Egységes elemzés csak a laza értelmező azon adatai esetében adható, amikor az értelmező után is tartunk intonációs szünetet, felerősítve ezáltal a szerkezet parentetikus jellegét. A példák alapján láthattuk, hogy ilyenkor a mátrix mondatbeli állítmányt az értelmezett szóval kell egyeztetni. Az elemzési javaslatom a ParP vagyis egy olyan parentetikus frázis alkalmazása, amelynek specifikálója az értelmezett szó, komplementuma az értelmező. Ahhoz, hogy az értelmező láthatatlan legyen a mátrix mondat számára, a kiegészítő összeolvasztás műveletét (Heringa 2012: 139-141) kell alkalmazni, ahogyan ezt az 1.2.4 pont alatti alfejezetben láthattuk, így az állítmánnyal való egyeztetést kizárólag az értelmezett szó tudja irányítani (70).

(70)

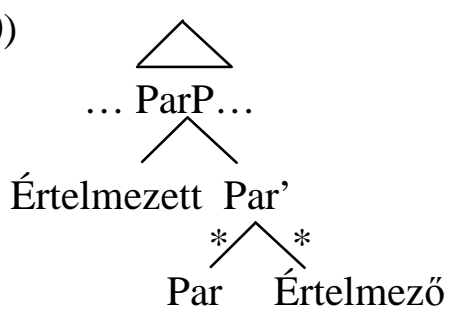

A következőkben vizsgáljuk meg, hogy az értelmező utáni intonációs szünet hiányában milyen szerkezet rendelhető az egyes appozíciófajtákhoz. 


\subsubsection{Az azonosítás és a tulajdonítás osztályába tartozó értelmezők elemzése}

Amint már korábban említettem, az azonosítás osztályába tartozó nominális értelmezők megfeleltethetőek az Ott (2014)-féle osztályozásban a specifikációs értelmezőknek, ezért ezt a két fogalmat egymás szinonimájaként fogom használni. Először is azt fogom bemutatni, hogy a magyar adatok valóban alátámasztják-e az Ott (2014) által javasolt elemzést, amely szerint a specifikációs értelmezőt tartalmazó tagmondat beékelödik a mátrix mondatba, s a redundáns elemek törölve vannak (71).

(71) [CP1 I met an old friend [CP2 Imet John Smith at the pub today] at the pub today]]

A specifikációs értelmezővel való egyeztetés alakulása a magyarban azonban ellentmond a (70)-es szerkezetnek, mivel vannak példák, amelyekben az értelmezővel kell egyeztetni a mátrix mondat állítmányát, amint ezt illusztrálja a (72)-es példa.
a. Egy bájos kislányt, Annát felkérték a fotózásra.
b. *[CP1 Egy bájos kislányt [CP2 Annát elkérték a fózásra] felkértek a fósra]

Mindebböl az következik, hogy egy másik szerkezetet kell rendelnünk az azonosítás szemantikai osztályába tartozó példákhoz a magyar nyelvben.

Amint láthattuk, a tulajdonítás osztályába sorolható nominális appozíciós konstrukciók az Ott (2014)-féle osztályozásban a predikációs értelmezőknek felelnek meg, így ezt a két fogalmat egymás szinonimájaként használom a továbbiakban. Ott (2014) olyan szerkezetet rendel a predikációs appozícióhoz, amelyben az értelmező egy lecsökkentett predikációs kopulás tagmondat (73).

(73) [CP1 I met John Smith [CP2 he is my best friend] at the pub today]

A (73)-as szerkezet azonban két okból sem alkalmazható a magyar predikációs értelmezők esetében. Először is a lecsökkentett predikatív mondat állítmányáról, vagyis az értelmezőről hiányzik a megfelelő esetrag (74), márpedig a magyarban az értelmezett szó és az értelmező mindig ugyanazt az esetvégződést viseli.

$$
\text { *[CP1 Az FTC-vel, [CP2 az FTC egy jó csapat] fogunk készíteni egy interjút.] }
$$


Másrészt nem adható magyarázat arra, hogyan történik az állítmánynak az értelmezővel való egyeztetése - ahogyan ez megfigyelhető az adatoknak egy jelentős hányadában. Az elemzést tovább nehezíti az a körülmény, hogy az egyeztetés alakulását a preverbális pozícióban megjelenő appozíció esetében két tényező (a közelségi elv és a jelölt jegyérték) befolyásolja, aminek következtében egyes példákban az értelmezett szóval, míg más példákban az értelmezövel történik az állítmány egyeztetése (75).

\section{(75) a. ?? Annát, egy bájos kislányt felkértek a fotózásra. b. ? Annát, egy bájos kislányt felkérték a fotózásra.}

A 3.4 pont alatti alfejezetben láthattuk, hogy ha az azonosítás és a tulajdonítás szemantikai osztályába tartozó értelmezős szerkezet preverbális pozícióban jelent meg, nem született egyértelmü grammatikalitási ítélet azokban az esetekben, amikor a jelölt jegyérték és a közelségi elv konfliktusba került egymással. Ebből adódóan mindkét értelmezős szerkezet esetében a következő az elemzési javaslatom: Az azonosítás és a tulajdonítás osztályába tartozó értelmezőt is egy appozíciós parentetikus frázisként $\left(\operatorname{Par}_{\mathrm{APP}} \mathrm{P}\right)$ elemezzük, megkülönböztetve azoktól az appozíciós szerkezetektől, amelyekben az értelmező után is tartunk szünetet. Ezekben a szerkezetekben az értelmező nem a kiegészítő összeolvasztás müveletével kapcsolódik az értelmezett szóhoz, mivel egyes esetekben az értelmező irányítja az állítmánnyal való egyeztetést, vagyis a mátrix mondat predikátumának látnia kell az értelmezőt is. Amikor a szerkezettagok nem ugyanolyan jegyértékkel rendelkeznek, akkor a jegykonfliktus eredményeként a $\operatorname{Par}_{\mathrm{APP}} \mathrm{P}$ a jelölt jegyértéket (a többességet vagy a határozottságot) fogja örökölni a jegyátszivárgásnak ${ }^{43}$ (feature percolation) köszönhetően. Az és-koordinációhoz hasonlóan (É. Kiss 2012) csak a jelölt jegyérték szivárog fel a $\operatorname{Par}_{\mathrm{APP}} \mathrm{P}-\mathrm{re}$, annak hiányában egyes számú, illetve határozatlan ragozás jelenik meg az állítmányon. Preverbális pozícióban lévő értelmezős konstrukció esetében két lehetőség van: $\operatorname{~Par}_{\mathrm{APP}} \mathrm{P}$ jegyértéke és a közelségi elvben szerepet játszó értelmező jegyértéke megegyezik (ebben az esetben az értelmező irányítja az állítmánnyal való egyeztetést), vagy konfliktusba kerülnek egymással (ebben az esetben tapasztalható ingadozás a grammatikalitási ítéletekben, és az állítmányt az értelmezett szóval és az értelmezővel is lehet egyeztetni). Mivel csak a preverbális pozícióban megjelenő értelmezős szerkezet esetében volt tapasztalható ingadozás a grammatikalitási ítéletekben, ezért a továbbiakban csak az ilyen példákra koncentrálok. Nézzük meg, milyen szerkezet rendelhető az

\footnotetext{
${ }^{43}$ Lieber (1989) szerint egy nem fejről is végbemehet a jegyátszivárgás, ha a fej nincs specifikálva az adott jegy számára.
} 
alanyi pozícióban megjelenő, az azonosítás szemantikai osztályába tartozó értelmezőhöz (7677).

(76) A két barátnöd, a lányaim megérkeztek /*megérkezett.

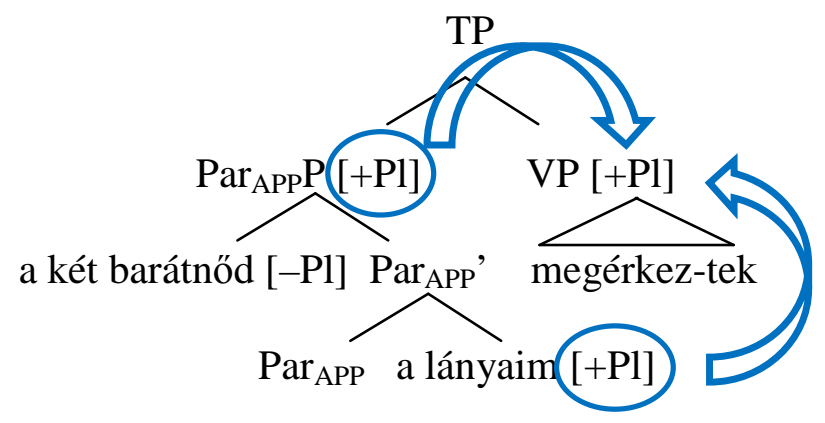

A (76)-os példában a közelségi elvben szerepet játszó értelmező és a $\mathrm{Par}_{\mathrm{APP}} \mathrm{P}$ jegyértéke megegyezik, így az állítmánnyal való egyeztetést kizárólag az értelmező irányíthatja.

A lányaim, a két barátnöd ?megérkeztek/??megérkezett.

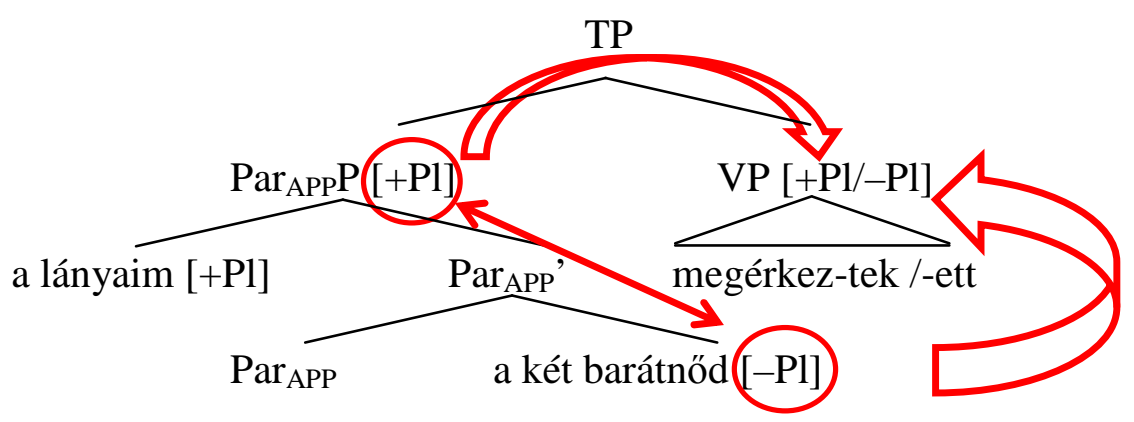

A (77)-es példában a közelségi elvben szerepet játszó értelmező és a $\operatorname{Par}_{\mathrm{APP}} \mathrm{P}$ jegyértéke konfliktusban áll egymással, így az állítmánnyal való egyeztetést a $\operatorname{Par}_{\mathrm{APP}} \mathrm{P}$ és az értelmező is irányíthatja, a többes számú és az egyes számú állítmány is grammatikus a mondatban - e kérdést tekintve az anyanyelvi beszélők grammatikalitási ítéleteiben ingadozás tapasztalható.

Az alábbiakban a tárgyi pozícióban megjelenő, az azonosítás osztályába tartozó értelmező szerkezetét fogom bemutatni (78). ${ }^{44}$

\footnotetext{
${ }^{44}$ Felmerülhet kérdésként, hogyan lehetséges, hogy az egy bájos kislány az egyik példában generikus határozatlan (78), míg a másik mondatban specifikus határozatlan interpretációt nyer (79). Heringa (2012) példákkal illusztrálja, hogy egy határozatlan NP lehet generikus, nem-specifikus, specifikus olvasatú a szövegkörnyezet függvényében (lásd a 13-as lábjegyzetet). A (78)-as példában a határozatlan NP azért lehet generikus határozatlan olvasatú, mert egy korábban már bevezetett diskurzus-referensre utal vissza. Ezzel szemben (79)-ben az egy bájos kislány egy új diskurzus-referenst vezet be egy konkrét szituációban, vagyis ennek megfelelően specifikus határozatlan interpretációt kap.
} 


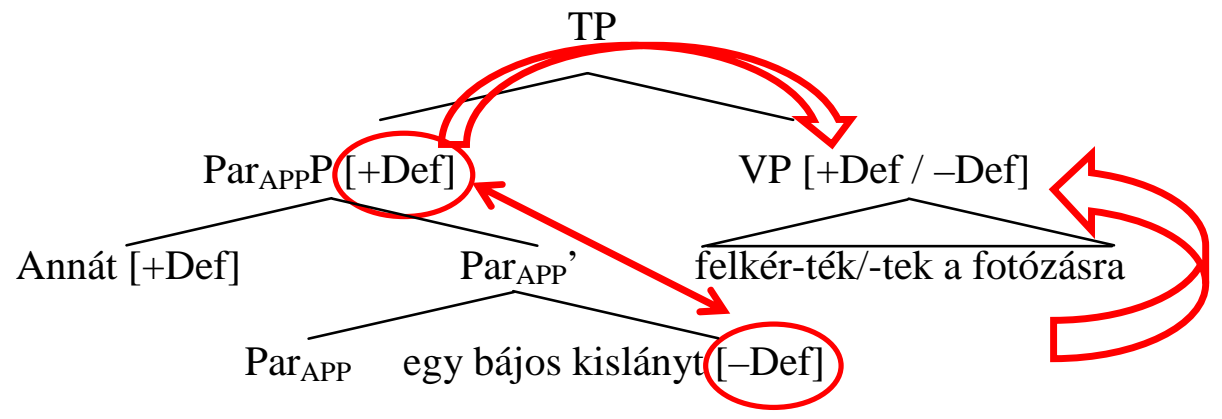

(78)-ban a közelségi elv alapján irányító szerepet játszó értelmező és a $\operatorname{Par}_{\mathrm{APP}} \mathrm{P}$ jegyértéke konfliktusba kerül egymással, ezáltal az állítmány lehet határozott és általános ragozású is - a szuffixum választásában ingadozás tapasztalható.

Az azonosítás osztályába tartozó értelmezőre nem hozható olyan példa, amelyben a tárgyi pozícióban megjelenő $\operatorname{Par}_{\mathrm{APP}} \mathrm{P}$ jegyértéke és a közelségi elvben szerepet játszó értelmező jegyértéke nem kerül konfliktusba egymással, mivel ebben az esetben már egy tulajdonító értelmezőt kapnánk. Ebből a tényből adódik, hogy a tárgyi pozícióban megjelenő, az azonosítás osztályába tartozó értelmező esetén, ha a szerkezettagok eltérő határozottságúak, akkor az értelmezővel (amely határozott) kell egyeztetni az állítmányt (79).

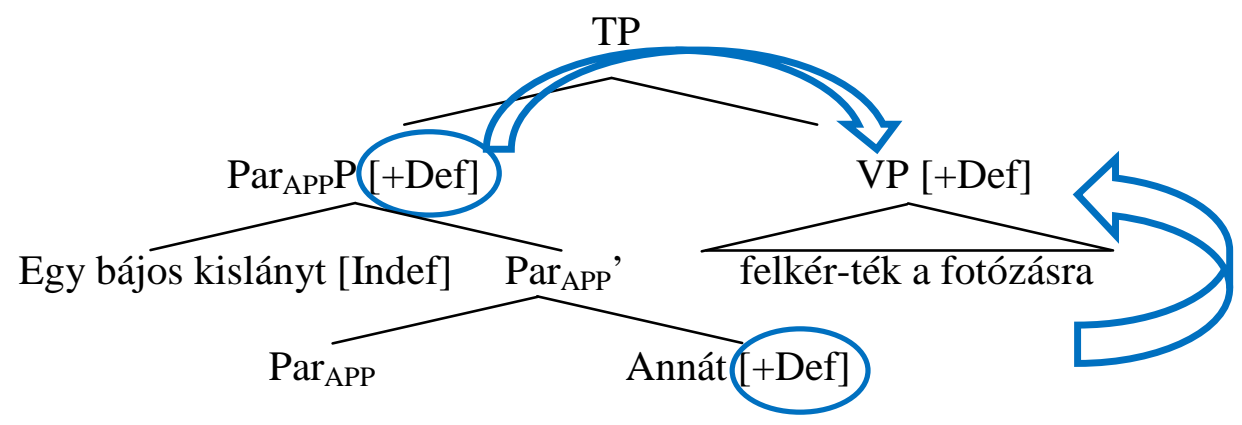

Amikor az azonosítás és a tulajdonítás osztályába tartozó értelmezős szerkezetek posztverbális pozícióban jelentek meg, egyértelmü grammatikalitási ítéletek születtek: ezekben az esetekben kizárólag a közelségi elv játszik szerepet az állítmánnyal való egyeztetés során $(80-81)$. 
(80)

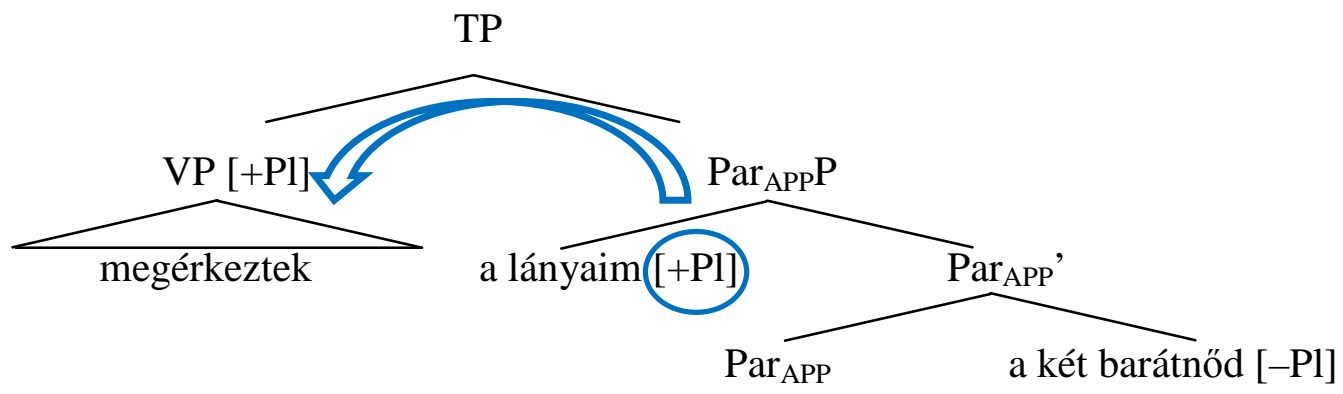

$(81)$

Megérkezett /* Megérkeztek a két barátnőd, a lányaim.

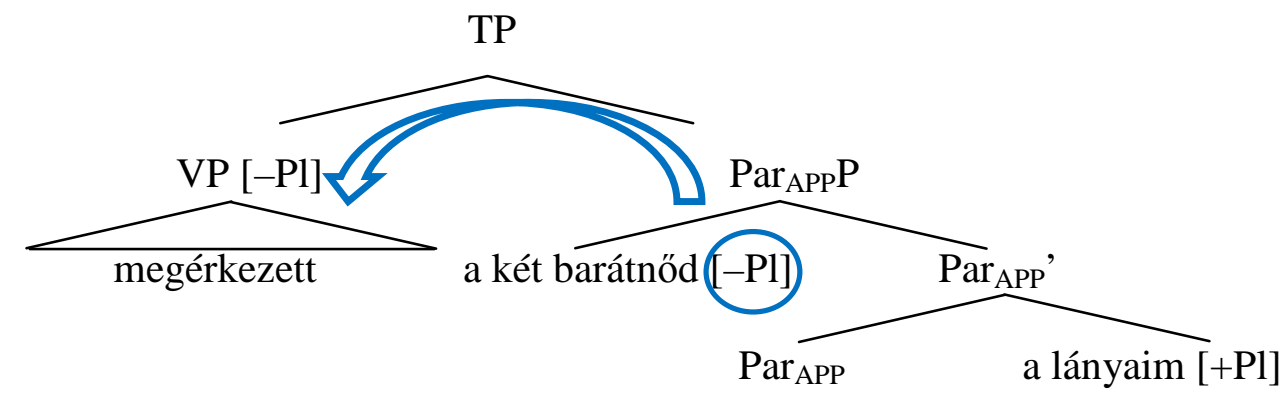

A posztverbális pozícióban megjelenő értelmezős szerkezet esetében - a közelségi elvnek köszönhetően - kizárólag az értelmezett szó irányítja az állítmánnyal való egyeztetést, az appozíciós konstrukció tagjai közti esetleges jegykonfliktus ebben az esetben nem kap semmilyen szerepet az egyeztetés során.

\subsubsection{A bennfoglalás osztályába tartozó értelmező elemzése}

Ennek a csoportnak nem szentelnek különösebb figyelmet a nemzetközi szakirodalomban, Heringa (2012) a példák számbavétele után kizárta ezeket a szerkezeteket a további vizsgálódások köréből, és ezen csoportot két tagmondat koordinációjaként és ellipszisként elemzi Burton-Roberts (1994)-es javaslata alapján. Ott (2014) pedig már az appozíció osztályozásakor figyelmen kívül hagyja ezeket a példákat.

A következőkben azt vizsgálom meg, hogy a magyar példák valóban alátámasztják-e azt az elemzési javaslatot, amely két tagmondat koordinációját és az azokon végrehajtott ellipszist feltételezi. A kérdés eldöntéséhez két tényezőt vizsgálhatunk meg: a bennfoglalást tartalmazó mondatok parafrázisát, illetve a bennfoglaló értelmezőnek az állítmánnyal való egyeztetését. Először nézzük meg, hogy a bennfoglalás példái hogyan alakíthatóak át (82). 
(82) a. Három jó barátom, köztuik Mari, elutazott hétvégén a hegyekbe.

b. *Három jó barátom köztük Mari.

c. Mari a három jó barátom egyike.

d. Három jó barátom elutazott hétvégén a hegyekbe, köztük Mari elutazott hétvégén a hegyekbe.

(82b) azt példázza, hogy a bennfoglaló értelmezős szerkezet két tagja között nem hozható létre predikatív viszony. (82c) már grammatikus parafrázisa a bennfoglaló értelmezőnek, de nem ez az, amit (82a)-ban a beszélő mondani akar. Valójában (82d)-vel adható vissza az értelmezős szerkezetet tartalmazó mondat jelentése, amely azt sugallja, hogy itt két tagmondat koordinációja történik.

Most vizsgáljuk meg, hogy az alanyként megjelenő bennfoglaló értelmezős szerkezet milyen egyeztetést vált ki az állítmányon (83).

a. */?? A barátaim, köztük Mari elutazott hétvégén a hegyekbe.

b. */?? Az emberszabású majmok, például a csimpánz nagy népszerüségnek örvend.

c. A barátaim, köztük Mari, elutaztak hétvégén a hegyekbe.

d. Az emberszabású majmok, például a csimpánz, nagy népszerüségnek örvendenek.

A (83a, b) példák agrammatikussága nemcsak abból a tényből fakad, hogy az állítmány az értelmezővel van egyeztetve, hanem az értelmező utáni intonációs szünet hiányából is, ahogyan ezt a (83c, d) adatok jólformáltsága mutatja. Az értelmező utáni intonációs szünet megjelenése felerősíti az értelmező parentetikus jellegét, és ebben az esetben - ahogyan az azonosítás és a tulajdonítás osztályába tartozó példáknál is láthattuk - az állítmány egyeztetése az értelmezett szóval történik. Az ilyen példákban az appozíciós konstrukció egy közbevetés lesz (ParP), amelyben a kiegészítő összeolvasztás művelete által kapcsolódik az értelmező az értelmezett szóhoz, ahogyan ezt a (70)-es ágrajzban láthattuk.

Ugyanakkor azonban el kell számolni azokkal a példákkal is, amelyekben a bennfoglaló értelmezős szerkezet fókuszpozícióban jelenik meg, ugyanis ilyenkor az értelmező után már nem tarthatunk intonációs szünetet a fókuszhangsúly miatt, és ilyen esetekben a mátrix mondat állítmányát egyértelmüen az értelmezővel kell egyeztetni (84). 
a. A barátaim, köztük Mari utazott / *utaztak el hétvégén a hegyekbe.

b. Az emberszabású majmok, de leginkább a csimpánz örvend / *örvendenek nagy népszerüségnek.

A (84)-es példákban az állítmánynak az értelmezővel való egyeztetése amellett szól, hogy az értelmező utáni intonációs szünet hiánya esetén a konstrukciót két tagmondat koordinációjaként és ellipszisként elemezzük (85).

(85) a. [CP1 A barátaim [utaztak el hétvégén a hegyekbe]], [CP2 köztük Mari utazott el hétvégén a hegyekbe].

b. [CP1 Az emberszabású majmok [ërvendenek nagy népszerüségnek]], [CP2 például a csimpánz örvend nagy népszerüségnek].

Felmerülhet a kérdés, hogy egyes appozíció-jelölők a bennfoglalás példáiban (ilyen például a köztük) nem olyan kötőszók-e, amelyek csak DP-t vezethetnek be. Ezt az alábbi példával cáfolnám, amely az én nyelvi intuícióm szerint egy jól formált mondat (86).

$$
\text { [CP1 Ami a barátaimat illeti], [CP2 köztük Mari is elutazott]. }
$$

\subsubsection{A szoros értelmező elemzése}

A szoros értelmezőben egy intonációs egységet alkot a szerkezet két tagja, mindig két DP jelenik meg a konstrukcióban, továbbá az egyetlen entitásra vonatkozó referenciát a két DP együttesen határozza meg. Ezek a tulajdonságok amellett szólnak, hogy a szoros értelmezőt ne tagmondatok koordinációjaként, hanem egyetlen összetevőként elemezzük. Ugyanakkor felmerül egy komoly kérdés: hogyan határozzuk meg a szerkezettagok közti viszonyt. A probléma megoldásának keresése során nem támaszkodhatunk az állítmánnyal való egyeztetés vizsgálatára, mivel nem generálhatóak olyan példák, amelyekben az értelmezett szó és az értelmező alanyként eltérő számú egyeztetést váltana ki külön-külön az állítmányon, illetve eltérő határozottságú tárgyként sem jelenhetnek meg.

További tulajdonságokat is figyelembe lehet venni a szoros értelmező elemzése során, ezek a következők: a szerkezettagok közé nem ékelődhet semmilyen más elem (beleértve az appozíció-jelölőket is), valamint a tagok csak megszorításokkal módosíthatóak (87). ${ }^{45}$

\footnotetext{
${ }^{45}$ A (87c) példa grammatikusságára Dékány Éva hívta fel a figyelmemet, amiért külön köszönet jár neki.
} 
(87) a. *Miltiadészt a gyöztes hadvezért sokkal többen ismerik, mint Miltiadészt a kevésbé ismert pápát.

b. *A híres Miltiadészt a hadvezért sokkal többen ismerik, mint a kevésbé ismert Miltiadészt a pápát.

c. Miltiadész a fiatal hadvezér sikeresebb volt, mint Miltiadész az idős hadvezér.

A szoros appozíció (88a) nagyon hasonlít az utógondolatra (88b) abban az értelemben, hogy mindkettő korlátozó értelmü.

(88) a. Petőfit a költő́t többre becsülték (mint Petőfit a nyelvészt).

b. Petöfit sokra becsülték, mármint a költöt (és nem a nyelvészt). $\neq$

c. Petőfit, a költöt sokra becsülték.

Az utógondolat (88a) - a korlátozó értelme miatt - nem ugyanazt a jelentést hívja elő, mint a laza értelmezős minimálpárja (88c).

Megvizsgálhatjuk a szoros értelmező fókuszként való megjelenését is, hogy a szerkezeti elemzéséhez közelebb jussunk (89).

(89) a. Kosztolányit az írót kedveltem meg az elmúlt évek során, (...)

b. (...) és nem Kosztolányit a költơtt.

c. (...) és nem a költöt.

d. *(...) és nem Móriczot.

A szoros értelmező esetében (89a)-nak a folytatása (89b), mivel ez a fajta appozíció két azonos nevü entitás közül választ, így fókuszként a két lehetséges entitást állítja szembe egymással. Ugyanakkor (89c) is lehet a folytatása (89a)-nak, hiszen ezáltal az értelmezett szót korlátozó két DP lesz egymással szembeállítva. (89d) azért nem lehet a fókuszos mondat folytatása, mert ebben az esetben a szoros értelmező használatát semmi sem követelné meg.

Az általam javasolt elemzés az, hogy az értelmezőt jobbról csatoljuk az értelmezett szóhoz, és a két DP egy összetevőt alkot (90). 
(90)

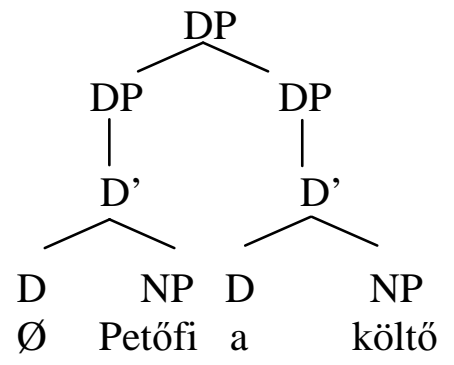

A (90)-ben látható elemzést követi Alberti-Medve a Generatív grammatikai gyakorlókönyv II. Ágrajzok (2002: 277)-ben, de azt fontos megjegyezni, hogy egy laza értelmezős példát (egy jómódú orvos ismerősöm, a Kovács Teofil doktor) elemeznek a fent látható módon.

\subsubsection{Egy komplex appozíciós konstrukció szerkezete}

Az azonosító értelmező tulajdonságait tárgyalva megmutattam, hogy a magyar értelmezős szerkezetnek is lehet saját ideje, alanya és határozója, vagyis a konstrukció valójában egy CPnek tekinthető. A következőkben azt fogom megmutatni, hogyan épül fel egy komplex appozíciós szerkezet (91).

(91) A tanárom, egykor maga is nagy dohányos, támogat a leszokásban.

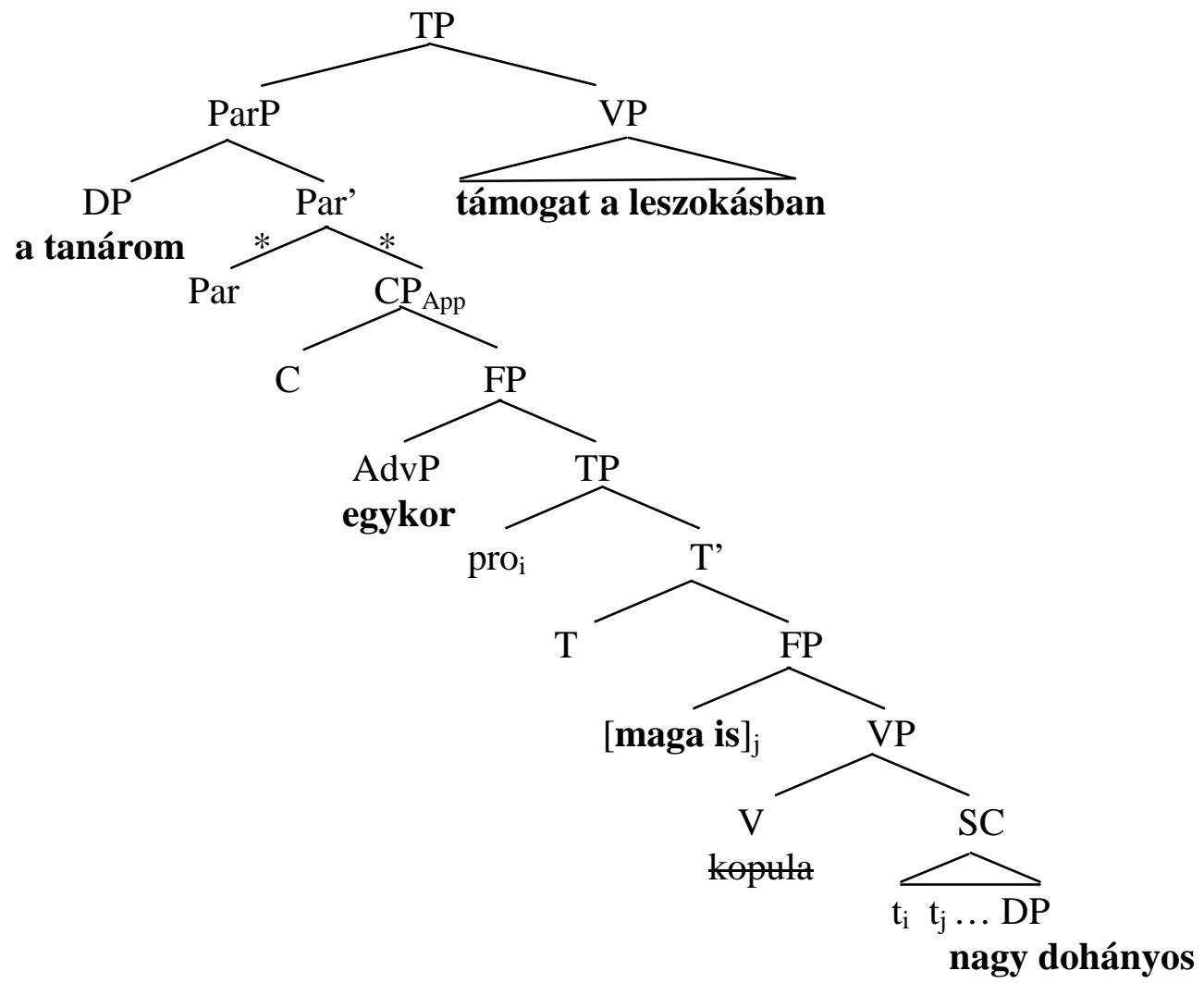


Maga az értelmező egy kis tagmondatnak (SC-nek) tekinthető, van egy saját pro alanya, amelynek jelenlétére a maga névmás utal, illetve egy időhatározóval is rendelkezik - ezáltal egy értelmezői $\mathrm{CP}\left(\mathrm{CP}_{\mathrm{App}}\right)$ építhető fel. Bár nincs kopula az értelmezői mondatban, annak mégis van - az időhatározó jelenléte erre utal - saját Tense jegye, amely a (91)-es példában eltér a mátrix mondat Tense jegyétől. Végül az értelmezői CP a kiegészítő összeolvasztás müvelete által kapcsolódik az értelmezett szóhoz.

Azt azonban hangsúlyozni kell, hogy a komplex appozíciós szerkezetek csak korlátozott számban jelenhetnek meg a magyar nyelvben. Saját alanya csak akkor lehet a konstrukciónak, ha az appozíciós szerkezet nem visel látható esetvégződést (92).

$$
\text { *A tanáromat, egykor maga is nagy dohányost, meglátogattam. }
$$

\subsection{Az 'én, a koronatanú' és a 'mi férfiak' szerkezetek elemzése}

Ebben az alfejezetben azokat az értelmezős szerkezeteket fogom megvizsgálni, amelyekben az értelmezett szó egy személyes névmás (93). Két különféle típusú konstrukcióval van dolgunk: (93a) esetében tartunk intonációs szünetet a szerkezet tagjai között, és határozott fönévi csoport jelenik meg értelmezőként, míg $(93 b, c)$ példákban nincs intonációs szünet az appozícióban, és határozatlan főnévi csoport jelenik meg értelmezőként.
a. Én, a koronatanú pontosan jelentem meg a bíróságon.
b. Mi férfiak mindig is határozottak voltunk.
c. Ti lányok igazán jól föztök.

\subsubsection{Az 'én, a koronatanú' szerkezetek}

Először azokat a szerkezeteket vizsgálom meg, amelyekben bármilyen számú és személyü személyes névmás megjelenhet értelmezett szóként, intonációs szünet van a szerkezeti tagok között, és határozott főnévi csoport alkotja az értelmezőt. A 13. táblázat ad egy összefoglalást a személyes névmást tartalmazó szerkezetekről, feltüntetve az angol adatokat is (DelormeDougherty 1972: 10, 12; Acuña-Fariña 1996b: 11), lehetőséget adva a két nyelv összehasonlítására. 
13. táblázat: A személyes névmást tartalmazó értelmezős szerkezetek

\begin{tabular}{|c|c|c|c|c|}
\hline & I. & II. & III. & \\
\hline $\mathrm{E} / 1$. & $\begin{array}{l}\text { Én, a koronatanú } \\
\text { (I, the boy) }\end{array}$ & $\begin{array}{l}\text { *Én, koronatanú } \\
(* \mathrm{I}, \text { boy) }\end{array}$ & $\begin{array}{l}\text { *Én a koronatanú } \\
(* \text { I the boy) }\end{array}$ & pontosan jelentem meg... \\
\hline $\mathrm{E} / 2$. & $\begin{array}{l}\text { Te, a koronatanú } \\
\text { (you, the boy) }\end{array}$ & $\begin{array}{l}\text { *Te, koronatanú } \\
\text { (*you, boy) }\end{array}$ & $\begin{array}{l}\text { *Te a koronatanú } \\
(* \text { you the boy) }\end{array}$ & pontosan jelentél meg... \\
\hline $\mathrm{E} / 3$. & $\begin{array}{l}\text { Ö, a koronatanú } \\
\text { (he, the boy) }\end{array}$ & $\begin{array}{l}\text { *Ö, koronatanú } \\
(* \text { he, boy) }\end{array}$ & $\begin{array}{l}\text { *Ö a koronatanú } \\
(* \text { he the boy) }\end{array}$ & pontosan jelent meg... \\
\hline $\mathrm{T} / 1$. & $\begin{array}{l}\text { Mi, a koronata- } \\
\text { núk } \\
\text { (we, the boys) }\end{array}$ & $\begin{array}{l}\text { Mi, koronatanúk } \\
\text { (we, boys) }\end{array}$ & $\begin{array}{l}\text { *Mi a koronata- } \\
\text { núk } \\
\text { (we the boys) }\end{array}$ & $\begin{array}{l}\text { pontosan jelentünk } \\
\text { meg... }\end{array}$ \\
\hline $\mathrm{T} / 2$. & $\begin{array}{l}\text { Ti, a koronata- } \\
\text { núk } \\
\text { (you, the boys) }\end{array}$ & $\begin{array}{l}\text { Ti, koronatanúk } \\
\text { (you, boys) }\end{array}$ & $\begin{array}{l}\text { *Ti a koronatanúk } \\
\text { (you the boys) }\end{array}$ & $\begin{array}{l}\text { pontosan jelentetetek } \\
\text { meg... }\end{array}$ \\
\hline $\mathrm{T} / 3$. & $\begin{array}{l}\text { Ök, a koronata- } \\
\text { núk } \\
\text { (they, the boys) }\end{array}$ & $\begin{array}{l}\text { *Ök, koronatanúk } \\
\text { (they, boys) }\end{array}$ & $\begin{array}{l}\text { *Ök a koronata- } \\
\text { núk } \\
\text { (*they the boys) }\end{array}$ & pontosan jelentek meg... \\
\hline
\end{tabular}

A példák II. oszlopában bővíthető a grammatikus adatok köre, ha az egyes számú személyes névmási értelmezett szó mellé határozatlan névelőjü értelmezőt helyezünk, és nem egy puszta főnevet (94).
a. Én, egy tanú a sok közül, pontosan jelentem meg a bíróságon.
b. Te, egy alkoholista, nem illessz a lányomhoz.
c. Ő, egy hivatásos színész, meggyőzően alakította a szerepét.

A (94)-es példákkal már majdnem teljessé vált a paradigma, az angol adatokhoz képest egyedül a többes szám harmadik személyü személyes névmási értelmezett szó mutat eltérést (*ők, koronatanúk).

A III. oszlop példái közül a többes szám első és második személyü értelmezett szó + határozott fönévi csoport alkotta szerkezetek mutatnak eltérést az angol grammatikus példákhoz képest. 
A 13. táblázat grammatikus példáiból jól látszik, hogy az állítmányt az értelmezett szóval, és nem az értelmezővel kell egyeztetni. Ebből adódóan ezeket a szerkezeteket nem lehet két tagmondat koordinációjaként elemezni (95).

*[CP1 Én [pentesan jelentem meg a bíróságon]], [CP2 a koronatanú pontosan jelent meg a bíróságon].

Többféle szerkezeti elemzés is lehetséges a személyes névmási értelmezős konstrukció esetében, a következőkben ezeket veszem sorra. Az egyik lehetséges eljárás, hogy az értelmezőt tartalmazó tagmondatot közbeékeljük a mátrix mondatba, és a redundáns elemeket elliptáljuk (96).

(96) [CP1 Én, [CP2 a koronatanú [pøntesan jelent meg a bíróságon]] pontosan jelentem meg a bíróságon].

Ezzel a megközelítéssel szemben azt az ellenérvet tudom felhozni, hogy az azonosító értelmező fajtáin belül egyedül a bennfoglalás szemantikai osztályába tartozó értelmezős szerkezeteket (azoknak is csak egy kis csoportját) lehet két tagmondat koordinációjaként és ellipszisként elemezni. A bennfoglalás osztályába tartozó példákról azonban láthattuk, hogy több ponton is eltérnek a többi appozíciófajtától.

Egy másik lehetséges elemzési mód, hogy az értelmezőt a kiegészítő összeolvasztás mủveletével kapcsoljuk az értelmezett szóhoz, aminek köszönhetően a mátrix mondat számára láthatatlanná válik, így a predikátummal való egyeztetésben kizárólag az értelmezett szó tud részt venni. Ezzel az eljárással szemben pedig az az ellenérv hozható fel, hogy ez a parentetikusabb jellegü értelmezők megkülönböztetésére szolgál, amelyektől azonban célszerü lenne elhatárolni ezeket a szerkezeteket. A másik ellenérv, hogy ez a fajta elemzés nem tud elszámolni az egyeztetéssel, ha a szerkezettagok sorrendjét felcseréljük, vagyis ha a személyes névmás az értelmező szerepét tölti be (97). ${ }^{46}$

\section{A koronatanú, vagyis én elmentem a bíróságra.}

\footnotetext{
${ }^{46}$ Bár ezen alfejezet célkitűzése a személyes névmást mint értelmezett szót tartalmazó szerkezetek vizsgálata, de érdemes figyelembe venni azokat a konstrukciókat is, amelyekben a névmás értelmezőként jelenik meg.
} 
A (97)-es példában az ige egyeztetése a második szerkezettaggal történik, ebböl adódóan a mátrix mondatbeli állítmánynak látnia kell az értelmezőt is, ezért nem egyesíthetjük a szerkezettagokat a kiegészítő összeolvasztás müvelete által.

A cél tehát egy olyan szerkezeti elemzés nyújtása, amely beilleszthető az egyes appozíciófajtákhoz rendelt megközelítések közé. A személyes névmást tartalmazó appozíciós konstrukciók esetében is irányíthatja az egyeztetést a jelölt jegyérték: ezekben az esetekben az 1. és 2. személyü jegyeket tekinthetjük jelöltnek a jelöletlen 3. személyü jegytartalommal szemben (Harley-Ritter 2002). Az értelmezős konstrukciók egy appozíciós parentetikus frázist ( $\left.\mathrm{Par}_{\mathrm{APP}} \mathrm{P}-\mathrm{t}\right)$ alkotnak, amelyben az értelmezett szó és az értelmező jegyértékei közül $\mathrm{Par}_{\mathrm{APP}} \mathrm{P}$ a jelölt jegytartalmat fogja örökölni, és ez a jelölt jegyérték fogja irányítani a predikátummal való egyeztetést abban az esetben, amikor az appozíció preverbális pozícióban jelenik meg (98).

\section{Én, a koronatanú, elmentem a bíróságra.}

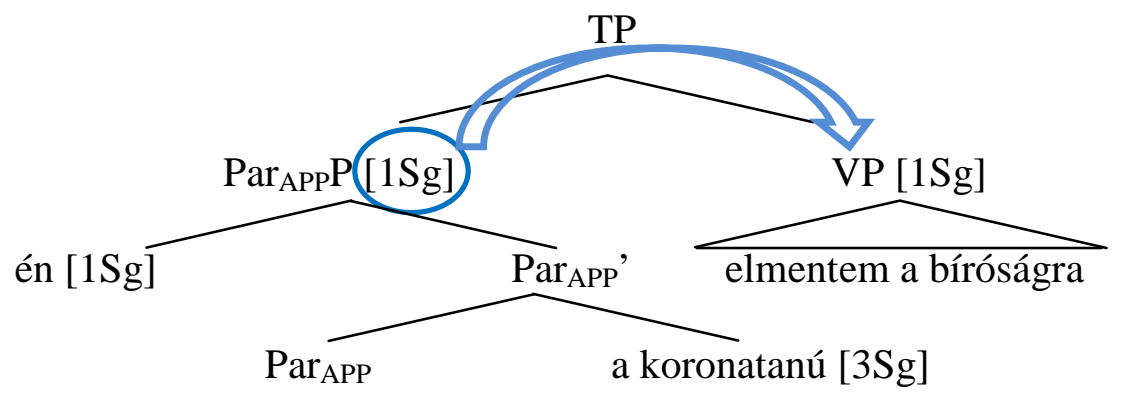

A posztverbális pozícióban megjelenő értelmezős szerkezet esetében - akárcsak az azonosítás és a tulajdonítás szemantikai osztályába tartozó példáknál - a közelségi elv alapján megy végbe a mátrix mondatbeli predikátummal való egyeztetés, erről azok a példák árulkodnak, amelyekben a személyes névmás értelmezőként jelenik meg (99).

\section{Elment a bíróságra a koronatanú, vagyis én.}

Ez a megközelítés azért jobb az előző kettőnél, mert így az azonosító appozíció egyes fajtáihoz - kivéve a bennfoglalás szemantikai osztályához - hasonló szerkezetet lehet rendelni. Ugyanakkor el kell ismerni, hogy a személyes névmást tartalmazó szerkezetek az egyeztetés tekintetében különbséget is mutatnak az azonosítás és a tulajdonítás szemantikai osztályába tartozó appozícióktól: míg a két utóbbi értelmezőfajta esetében ingadozás tapasztalható az egyeztetés során, amikor a közelségi elv és a jelölt jegyérték konfliktusba kerül egymással 
(preverbális pozícióban), addig a személyes névmási értelmezős példákban (szintén preverbális pozícióban) mindig a jelölt jegyérték irányítja az állítmánnyal való egyeztetést.

Ha azonban megvizsgáljuk a tárgyi szerepet betöltő appozíciós konstrukciókat (100), adódik egy újabb probléma ezzel a megközelítéssel.

(100) Engem, a koronatanút ismételten behívtak / *behívták a bíróságra.

Tárggyal való egyeztetésnél a jelölt jegyérték a határozottsági jegy lenne, de a (100)-as példában azt láthatjuk, hogy az egyeztetés során se a közelségi elv, se a jelölt jegyérték nem irányadó. Ez a kéréskör visszavezethető a személyes névmásokkal való egyeztetés problematikájára, hiszen „furcsa törésvonal húzódik meg az 1. és 2. személyü, valamint a 3. személyü névmások viselkedesében: az előbbiek alanyi ragozású igével állnak, míg az utóbbiak tárgyas ragozásúval” (Bartos 2000c: 155). Farkas (1990) szerint az 1. és 2. személyü névmások ,inherensen határozottak", ezért nem szükséges a morfoszintaxisban ezen elemek határozottként való elemzése. Tény, hogy ha a tárgyi szerepet betöltő, személyes névmást tartalmazó appozíció preverbális pozícióban jelenik meg, mindig a személyes névmás irányítja az állítmánnyal való egyeztetést (függetlenül attól, hogy a névmás értelmezett vagy értelmező), míg ha posztverbális pozícióban áll, a közelségi elv veszi át az irányító szerepet az egyeztetés során. Ezek a szerkezetek további vizsgálatot igényelnek, kiterjesztve a kutatást a személyes névmások kérdéskörére is.

\subsubsection{A 'mi férfiak' szerkezetek}

A következökben olyan szerkezeteket fogok megvizsgálni, amelyekben a személyes névmás jelenik meg értelmezett szóként, mégpedig úgy, hogy az értelmező előtt nem tartunk intonációs szünetet. Az angol nyelvhez (101) hasonlóan a magyarban (102) sem teljes a paradigma. A (101)-es példák származási helye: Acuña-Fariña (1996b: 11).
(101)
a. *I a boy (*én egy fiú’)
d. we boys ('mi fiúk')
b. *you a boy (*'te egy fiú')
e. you boys ('ti fiúk')
c. *he a boy
(*`ő egy fiú’)
f. ? they boys (*'ők fiúk’)
(102)
a. *Én egy tanár keveset keresek.
d. Mi tanárok keveset keresünk.
b. *Te egy tanár keveset keresel.
e. Ti tanárok keveset kerestek.
c. *Ö egy tanár keveset keres.
f. ??/*Ök tanárok keveset keresnek. 


\subsubsection{A determináns-elmélet}

Postal (1964), Burton-Roberts (1975), Huddleston (1984) szerint a (101)-hez hasonló példákban a személyes névmások valójában a határozott névelők egyik típusa. Postal (1964) szerint a vizsgált NP-kben a főnévi fej a one(s), és ennek determinánsa a személyes névmás (103).

$$
\begin{aligned}
& \text { (103) a. I (one) } \\
& \text { b. we (ones) }
\end{aligned}
$$

Mivel a beszélt nyelvben a (103)-as szerkezetek rendszerint nem hangzanak el, Postal a Névmás-törlési szabályt alkalmazza (PRO DEL), melynek eredményeként csak a névmások jelennek meg a felszínen. Bár egyes angol dialektusokban találkozunk a we’uns, illetve a you'uns formával, de Postal elméletének igazi motivációja a we men ('mi férfiak') szerkezetek létezése. Ezekben a szerkezetekben a személyes névmás paradigmatikus kontrasztban áll a határozott névelővel és egyéb determinánssal (104). A (104)-es adatok Acuña-Fariña (1996b: 8)-ból származnak.

(104) a. We men will stay in this position.

'Mi férfiak ebben a pozícióban fogunk maradni.'

b. The men will stay in this position.

'A férfiak ebben a pozícióban fognak maradni.'

c. Some men will stay in this position.

'Néhány férfi ebben a pozícióban fog maradni.'

\subsubsection{Az értelmezős elmélet}

Delorme-Dougherty (1972), Quirk et al (1985) amellett foglalnak állást, hogy az ilyen típusú szerkezetek értelmezők. Szerintük a disztribúciós hasonlóság, amire Postal épít, csekély jelentőséggel bír. Felvetik azt a kérdést, ha a személyes névmás determináns, akkor mi magyarázza az alábbi agrammatikus példákat (105a-c). A (105-106)-os példák Delorme-Dougherty (1972: 12, 13)-ból származnak.
(105)
a. *I boy
(*én fiú')
d. we boys
('mi fiúk')
b. *you boy
(*'te fiú’)
e. you boys
('ti fiúk')
c. *he boy
(*'ő fiú’)
f. they boys
$(? ? / *$ ‘ők fiúk’) 
Az (a-c) példák agrammatikusságára nem lehet morfofonemikus tényként hivatkozni, ahogyan Postal teszi, ugyanis további hasonló adatokat is lehet találni az angolban, a teljesség igénye nélkül nézzünk meg egy példát (106).
a. *Smallest ones eat a lot.
*'Legkisebbek sokat esznek.'
b. The smallest ones eat a lot.
'A legkisebbek sokat esznek.'
c. *We smallest ones eat a lot.
*'Mi legkisebbek sokat eszünk.'
d. We, the smallest ones, eat a lot.
'Mi a legkisebbek sokat eszünk.'

Delorme-Dougherty szerint a névmást ezekben a szerkezetekben egy egész NP-nek kell követnie, nem csak egy N-nek. Ez kizárja, hogy determinánsok legyenek a névmások. Az értelmezős elemzés magyarázatot ad a Postal által morfofonemikus tényként kezelt adatokra is, vagyis hogy a (többes számú) névmások megjelenhetnek közvetlenül egy többes számú fönév előtt, de közvetlenül egy egyes számú puszta főnév előtt már nem jelenhet meg névmás. Ennek két oka van: 1) csak egy NP jelenhet meg az appozíciós szerkezetben egy olyan NP-vel, amelynek névmási feje van, 2) a többes számú határozatlan főnévi csoport determinánsa null (boys), míg az egyes számú határozatlan főnévi csoport determinánsa nem null (a boy). Ebből adódóan az értelmezős szerkezetben sem jelenhet egyes számú puszta főnév (*I boy).

Míg Postal elemzése egy ad hoc mechanizmust kívánna meg a (105a-c) példák blokkolására, addig az értelmezős elemzés egy ad hoc mechanizmust kívánna meg ezek generálására. Az értelmezős elmélet a (106)-os példákra is magyarázatot ad, hiszen a rosszul formált adatok (pl. *smallest ones) nem jelenhetnek meg összetevőként az appozícióban.

\subsubsection{Egy harmadik megközelítés - idioszinkratikus minta}

Acuña-Fariña (1996b) szintén elveti Postal determináns-elméletét Delorme-Dougherty (1972) érveire hivatkozva. Ugyanakkor az appozíciós elmélettel kapcsolatban is felvet néhány kérdést. Az első probléma az, hogy Delorme-Dougherty nem határozzák meg pontosan, hogy mi is az appozíció (amelyben az értelmező vesszö-intonációval vagy anélkül is elkülönülhet az értelmezettől). A vessző-intonáció hiányára hozott példáik: a fact ('tény’), answer ('válasz'), 
question ('kérdés') főnevek és komplementumaik. Appozíciós szerkezetnek tartják a my brother Bill ('Bill bátyám'), the answer yes ('az igen válasz'), the word apple ('az alma szó') példákat is, ahol nincs szünet az elemek elkülönítésére, és ezekre az adatokra úgy tekintenek, amelyek alátámasztják, hogy a hangsúly, az intonáció nem szükséges az appozícióban. Vagyis a komplementumok és a módosítók is lehetnek appozíciók, de nem határozzák meg, hogy mikor nem azok. Továbbá nem határozzák meg, mit értenek az appozíciós jelentés alatt, amellyel a vizsgált szerkezetek - szerintük - mindig rendelkeznek. A harmadik probléma az, hogy az értelmezős elmélet nem magyaráz meg minden adatot. Az appozíciós szabály alkalmazásával a következő paradigmát kapjuk (107-108), ahol minden példában erős intonációs szünet van a szerkezet tagjai között. Mivel Delorme-Dougherty a szünet nélküli példákat vizsgálták, ezért azt állítják: az appozíciós szerkezetekben a többes számú határozatlan névelőjü értelmező vessző-intonációval vagy anélkül is követheti az értelmezettet (108d-f, 110df). E tekintetben hasonlítanak a határozott névelös appozíciós szerkezetre (107d-f, 109d-f). Azonban ez a fajta párhuzam figyelmen kívül hagyja a szünettel bíró és a szünet nélküli példák közti különbségeket, hiszen nagyon fontos eltérés, hogy a szünet nélküli, vagyis a korlátozó paradigma több mint 60\%-a agrammatikus. (Tény: mind a 12 nem korlátozó példa jó, míg csak 4 korlátozó példa jó - első és második személyek többes számban.) Minden megcsillagozott példa két NP-t foglal magában, és ez azt jelenti, hogy Delorme-Dougherty szabálya nem elég, hogy a jól formált sorokat generálja, és a rosszul formáltakat blokkolja. A (107110) példák Acuña-Fariña (1996b: 11)-ben találhatók.

\begin{tabular}{|c|c|c|c|c|}
\hline (107) & a. I, the boy & ('én, a fiú') & d. we, the boys & ('mi, a fiúk') \\
\hline & b. you, the boy & ('te, a fiú') & e. you, the boys & ('ti, a fiúk’) \\
\hline & c. he, the boy & ('ő, a fiú') & f. they, the boys & ('ők, a fiúk’) \\
\hline (108) & a. $I$, a boy & ('én, egy fiú’) & d. we, boys & ('mi, fiúk’) \\
\hline & b. you, a boy & ('te, egy fiú') & e. you, boys & ('ti, fiúk’) \\
\hline & c. he, a boy & ('ő, egy fiú’) & f. they, boys & (??/*'ők, fiúk’) \\
\hline (109) & a. *I the boy & (*én a fiú’) & d. we the boys & (*‘mi a fiúk’) \\
\hline & b. *you the boy & (*'te a fiú’) & e. you the boys & (*‘ti a fiúk’) \\
\hline & c. *he the boy & (*`ő, a fiú’) & f. *they the boys & (*`ők a fiúk’) \\
\hline (110) & a. *I a boy & (*eén egy fiú’) & d. we boys & ('mi fiúk’) \\
\hline & b. *you a boy & (*'te egy fiú’) & e. you boys & ('ti fiúk') \\
\hline & c. *he a boy & (*`ő egy fiú’) & f. ?they boys & (*`ők fiúk’) \\
\hline
\end{tabular}


Acuña-Fariña a személyes névmásokkal kapcsolatban a következőket emeli ki: mivel deiktikus formák, a megfelelő interpretálásukhoz mindig kell a pragmatikai szituáció, amelyben a beszédaktus történik. Az 1. és 2. személyü névmások minden referenciális specifikációt tartalmaznak az egyénre vonatkozóan, ezért rendszerint nem engednek további korlátozást (csak a nem korlátozó bővítést). A we men szerkezet azonban ellentmond ennek az általánosításnak, és vannak további kivételek is $(111 \mathrm{a}-\mathrm{c})$.
$(111)$
a. Silly me!
e. *Silly they!
'Én ostoba!'
*`Ök ostobák!’
b. You there.
f. *He there.
'Te ott.'
?'Ö ott.'
c. You in the raincoat.
g. *He in the raincoat.
'Te az esőkabátban.'
'Ö az esőkabátban.'

Pragmatikai magyarázatot adhatunk arra, hogy miért csak többes számban lehetséges a korlátozás a we men ('mi férfiak') szerkezetekben. Egyes szám 1. és 2. személyü névmás esetében pontos a referencia, de többes számnál szükség lehet annak meghatározására, hogy pontosan mely egyéneket jelenti a névmás. Ugyanakkor azonban arra nincs magyarázat, hogy ez miért nem müködik 3. személyben is. Erre nincs formális magyarázat, ezen a konstrukción nem lehet alkalmazni a névmás szintaktikai kategóriájára jellemző prototipikus feltételeket. Vagyis az olyan szerkezetek, mint a we men, atipikusan viselkednek a személyes névmás nyelvtanát illetően. Így egy formális kritérium hiányában Acuña-Fariña arra a konklúzióra jut, hogy a kérdéses szerkezetek az idioszinkratikus szintaxis részét képezik.

\subsubsection{A szerkezet elemzése}

Amellett foglalok állást, hogy a mi férfiak szerkezet a szoros értelmezővel mutat rokonságot. A paradigma hiányzó adatait pragmatikai okokkal magyarázhatjuk, ahogyan Acuña-Fariña tette, kiegészítve azt a 3. személyü névmásra vonatkozó megállapításokkal. A 3. személyü névmással sem lehet korlátozó értelmezős szerkezetet létrehozni, ennek oka: a 3. személyü névmás vagy anaforikus vagy deiktikus, az interpretálásához lennie kell valamilyen előzménynek, amelyből pontosan „,azonosítható”, és ekkor már nem lehet korlátozó módon bővíteni (112). 

a. Marit ${ }_{i}$ kitüntették.
b. $O_{i}$, az iskola legjobb diákja mindig is jól tanult.
c. $* O_{i}$ a diák mindig is jól tanult.

Vannak azonban olyan adatok, amelyek látszólag ellentmondanak annak, hogy az egyes szám 2. személyü névmásokat nem lehet korlátozni (113).
(113)
a. Te ott az ablaknál, gyere ide!
b. Téged ott az ablaknál mindenki ismer.

Ezek a példák azonban a megszólítások (114) közé tartoznak, amelyek morfológiai, szintaktikai szempontból is másképp viselkednek, mint a mondat többi alkotóeleme. (113b) esetében is - noha a névmás esetet és thematikus szerepet is kap - amellett foglalok állást, hogy pragmatikai értelemben megszólítjuk a hallgatót egy olyan kontextusban, ahol több résztvevő is jelen van.

(114) Te gyerek, ma még ki fogod húzni a gyufát!

\subsection{A határozói értelmező}

Az első kérdés, amely felmerül, vajon tényleg érdemes-e megkülönböztetni a határozói értelmezőket a többi értelmezőfajtától. Ha a válasz igen, akkor újabb kérdés vetődik fel: vajon hol húzható meg a határ az egymással értelmezős viszonyban álló határozók, illetve az egymástól független határozók között. Mi akadályozhat meg abban bennünket, hogy (115a, b) mintájára (115c)-t is értelmezőnek tartsuk?

(115) a. Kecskeméten, a fớtéren, a null kilométerkőnél találkozzunk!

b. Lent a völgyben egy hatalmas tó terül el.

c. Holnap 4-kor fogunk találkozni.

A (115a) példa a bennfoglalás szemantikai osztályába tartozó értelmezőkhöz hasonlít, de egy fontos különbséget ki kell emelni: a határozók között nem kell megjelennie appozíciójelölőnek a bennfoglaló értelmezőkkel ellentétben. (115b) a szoros értelmezőhöz hasonlít abban, hogy nem tartunk szünetet a két határozó között, ugyanakkor megsérti a szoros értelmező 
egyik fö jellemzőjét, mely szerint két DP kerülhet csak egymással ilyen viszonyba. További tulajdonsága (115b)-nek, hogy a két határozónak nem kell szomszédosnak lennie egymással, eltávolodhatnak egymástól anélkül, hogy utógondolatként kellene értelmezni a második elemként megjelenő határozót (116). Ehhez hasonlóan viselkednek a határozók a (115c) példában is, ahogyan az a (117)-ben látható.

(116) a. Lent egy hatalmas tó terül el a völgyben.

b. Egy hatalmas tó lent terül el a völgyben.

c. A völgyben lent egy hatalmas tó terül el.

(117) a. 4-kor fogunk találkozni holnap.

b. 4-kor fogunk holnap találkozni.

Először is amellett fogok érvelni, hogy (115c) nem értelmezős szerkezet. Ha megfigyeljük a (118)-as példamondatot, azt láthatjuk, hogy a két időhatározó más-más pozícióban jelenik meg: a 4-kor topik, míg a holnap fókusz szerepét tölti be a mondatban.

\section{4-kor holnap fogunk találkozni (, és nem holnapután).}

Mivel a két időhatározó - még egymás mellé kerülve is - megjelenhet más-más szintaktikai pozícióban, nem tekinthetjük őket értelmezős szerkezetnek. Ezen állítás bizonyításához hasonlítsuk össze a valódi értelmezős szerkezetekkel a két határozó megjelenését! Egyrészt az értelmezős szerkezet tagjai csak úgy szakíthatók el egymástól, ha a második elem utógondolatként kapcsolódik a mondathoz (119a). Másrészt az értelmezős szerkezet tagjai mindig ugyanabban a szintaktikai pozícióban jelennek meg (119b).

(119) a. A barátnőmre várok már hosszú percek óta, vagyis Marira. / *A barátnőmre várok Marira már hosszú percek óta.

b. A barátnőmet, Marit hívtam meg vacsorára (, és nem a fönökömet). / A barátnőmet, vagyis Marit hívtam meg vacsorára (, és nem a fönökömet).

A (119a)-ban jól látszik, hogy a valódi értelmezős szerkezet (a barátnőmre, Marira) esetében a két elem csak úgy szakadhat el egymástól, ha a második összetevő a mondat végére kerül utógondolatként, a mondat közepébe csak nagyon erős intonációs szünettel és hangsúllyal ágyazódhat egyfajta közbevetésként (120). Ezzel szemben (117)-ben láthattuk, hogy a két 
időhatározó a mondatban bárhol megjelenhet anélkül, hogy a második elemet utógondolatnak vagy közbevetésnek kellene tartanunk.

(120) A barátnőmre várok - vagyis / mégpedig Marira - már hosszú percek óta.

Másrészt a valódi értelmezős szerkezet esetében az egész appozíciós konstrukció kerül a fókuszpozícióba, erre utal, hogy a (119b) példában a fönökömet nem a szerkezet második tagjával állítható szembe, hanem az egész értelmezős konstrukcióval. Ezzel szemben (118)-ban láthattuk, hogy csak a második határozó áll fókuszban.

A fentiekből adódóan kizárom az értelmezők köréből azokat a határozókat, amelyek együttes megjelenése esetén a következő tulajdonságok mutathatóak ki: a két határozó sorrendje tetszőleges, a mondatban egymástól távolabbra is kerülhetnek anélkül, hogy a második elem utógondolat vagy közbevetés lenne, illetve még ha szomszédosak is egymással, csak a második határozó foglalhatja el a fókusz pozícióját. Vagyis mindezek alapján a (115c) mondatban található időhatározók nem tekinthetőek értelmezős szerkezetnek.

Vizsgáljuk meg, hogy (115b) példa esetében a fenti tulajdonságok közül melyek figyelhetőek meg. (117a)-ban láthattuk, hogy az időhatározók sorrendje tetszőleges, egymástól távolabbra is kerülhetnek, mégsem válik a második elem utógondolattá vagy közbevetéssé. Az azonban kérdés, hogy a két határozó együttesen megjelenhet-e a fókuszpozícióban. Ennek eldöntéséhez vessük össze a következő adatokat (121-123).

(121) a. Bent a szobában olvadt ki a jég, és nem bent a konyhában.

b. Bent a szobában olvadt ki a jég, és nem kint az udvaron.

(122) a. Annát a kislányt kérték fel a fotózásra, és nem Annát az édesanyát.

b. Annát a kislányt kérték fel a fotózásra, és nem az édesanyát.

a. A bájos kislányt kérték fel a fotózásra, és nem a kisfiút.

b. A bájos kislányt kérték fel a fotózásra, és nem a pityergöt / a pityergö kislányt.

(121)-ben a bent a szobában határozók a lent a völgyben szerkezettel mutatnak rokonságot, és amint látható, fókuszpozícióban hasonlóan viselkednek a szoros értelmezőhöz (122), illetve egy melléknévvel módosított főnévi csoporthoz (123). (123a)-ban a fókuszban álló egész DPvel állítjuk szembe a kisfiút, míg (123b)-ben a DP-nek egy eleme, a bájos kerül fókuszpozícióba. Hasonló viselkedési minta figyelhető meg a két határozó és a szoros értelmező esetében is. Ennek alapján amellett érvelek, hogy a bent a szobában típusú határozók - egymás mellett 
megjelenve - értelmezős szerkezetet alkotnak, mégpedig a szoros értelmezőhöz hasonlóan egy összetevőt hozva létre.

Összegzésként elmondható, hogy érdemes a határozói értelmezőt megkülönböztetni az azonosító appozíciótól, hiszen attól eltérő tulajdonságokat mutat. Ugyanakkor azonban határt kell szabni annak, hogy két határozót mikor tartunk értelmezős szerkezetnek.

\section{8 Összefoglalás}

Ebben a fejezetben az azonosító értelmező állt a vizsgálódás középpontjában. Először az azonosító értelmező tulajdonságait vizsgáltam meg, módosítva, illetve kiegészítve a magyar szakirodalom egyes állításait: egyrészt az appozíciót sem tekintem jelzőnek (hasonlóan a hátravetett jelzői értelmezőhöz), másrészt a szerkezettagok felcserélésével egyes példákban itt is létrehozható elöl álló jelzőt tartalmazó konstrukció. Továbbá az azonosító értelmező olyan tulajdonságainak a vizsgálatára helyeztem a hangsúlyt, amelyek igazolhatják a mátrix mondattól való függetlenségét. A magyar azonosító értelmezős szerkezetben is megjelenhet a szerkezettagok között határozó, a konstrukciónak lehet saját pro alanya, amelyre a maga visszaható névmás jelenléte utal, ugyanakkor az értelmezőnek ugyanazt az esetragot kell viselnie, mint az értelmezett szónak.

Az azonosító értelmező fajtáinak ismertetésekor két újfajta megközelítési módot mutattam be, és amellett érveltem, hogy a magyar nyelvben is van létjogosultsága a szoros értelmezőnek, annak ellenére, hogy nyelvünkben korlátozottabb módon jelenik meg, mint a nemzetközi szakirodalomban ismertetett nyelvekben. Megvizsgáltam azt is, hogy az angol, a német és a holland példák mintájára vajon a magyar azonosító értelmezők is besorolhatóak-e a Heringa (2012) által bemutatott három szemantikai osztályba. Ennek a kérdésnek azért van jelentősége, mert amellett érveltem, hogy egyes kötőszók (az ún. appozíció-jelölők) megjelenése esetén a magyar nyelvben - a hagyománnyal ellentétben - nem mellérendelő szintagmáról, hanem értelmezős szerkezetről kell beszélnünk. A kutatásom során kitértem arra is, hogy az appozíció-jelölők - a Heringa (2012) által vizsgált nyelvekhez hasonlóan - a magyarban is elkülöníthetőek-e, egy-egy szemantikai osztályhoz kapcsolva őket. Az angol, a német és a holland példákkal egybevetve azonban a magyar adatok esetében nem lehet egyértelmüen csoportosítani az egyes appozíció-jelölőket azzal a kikötéssel, hogy az értelmezős szerkezetnek csak egy adott szemantikai osztályára jellemzőek, ugyanis az azonosítás egyes appozíciójelölői (mint a vagyis, azaz, mégpedig) olyan példákban is megjelenhetnek, amelyek a tulajdonítás osztályába sorolhatók. 
Az alanyi vagy tárgyi szerepben megjelenő azonosító értelmezős szerkezettel való egyeztetést is alapos vizsgálat alá vetettem, mivel azon kérdés megválaszolása, hogy az értelmezett szóval vagy az értelmezővel egyeztetjük az állítmányt, segíthet annak eldöntésében, hogy alá- vagy mellérendelő szerkezettel állunk szemben. Az eredmények alapján azonban nem lehet egyértelmüen állást foglalni amellett, hogy melyik szerkezettaggal történik az egyeztetés, ugyanis két tényező alakítja egyszerre az egyeztetés alakulását a preverbális pozícióban megjelenő appozíciós konstrukció esetén: a közelségi elv és a jelölt jegyérték a többességet, illetve a határozottságot illetően. Ha az értelmező többes számú alany vagy határozott tárgy, akkor egyértelmű az egyeztetés alakulása: többes számú, illetve határozott tárgyi ragozású ige jelenik meg (a közelségi elv is a többes számú, illetve a határozott tárgyi ragozású állítmányt erősíti meg). Ha az értelmezett szó a többes számú alany vagy a határozott tárgy, akkor a preverbális pozícióban megjelenő értelmezős szerkezet esetében a közelségi elv és a jelölt jegyérték (a többességi, illetve a határozottsági) szembekerül egymással, és a mondatok grammatikalitásának megítélése igen vegyes képet mutat az egyeztetés alakulását illetően. Ha az értelmezős szerkezet posztverbális pozícióban jelenik meg, akkor a közelségi elv az irányadó az egyeztetés alakulását tekintve mind az alanyi, mint a tárgyi szerepben megjelenő appozíció esetében. Példákkal illusztráltam, hogy az értelmező után tartott intonációs szünet hogyan befolyásolja az egyeztetés alakulását (a preverbális pozíóban megjelenő appozíciós konstrukció esetén): mind az alanyi, mind a tárgyi szerepü értelmezős szerkezet esetében az értelmezett szó irányítja az állítmánnyal történő egyeztetést, mivel a szünetnek köszönhetően felerősödik a konstrukció közbevetéses jellege.

A szerkezeti elemzés során kizártam három megoldási javaslatot: egyrészt az appozíciós szerkezet lecsökkentett vonatkozói tagmondatként való felfogását, másrészt ellipszisként való elemzését, harmadrészt az értelmezős konstrukció RELATOR-os elemzését a szerkezettagok között lévő predikatív viszonyra építve.

A disszertációban amellett érveltem, hogy a szerkezeti elemzés során az azonosító értelmező egyes fajtáit (az azonosítás, a tulajdonítás és a bennfoglalás szemantikai osztályába tartozó appozíciókat, a szoros értelmezőt) el kell határolni egymástól. Külön típusként elemeztem azokat a példákat, amelyekben az értelmező után is kell tartani intonációs szünetet, azokat a közbevetések közé sorolva. Mivel az állítmány egyeztetése az értelmezett szóval történik ezekben a példákban, amellett foglaltam állást, hogy az értelmezőnek a kiegészítő összeolvasztás művelete által kell az értelmezett szóhoz kapcsolódnia, hogy láthatatlan legyen a mátrix mondatbeli állítmány számára. Az azonosítás és a tulajdonítás osztályába tartozó értelmező esetében egy olyan appozíciós parentetikus frázist $\left(\operatorname{Par}_{\mathrm{APP}} \mathrm{P}-\mathrm{t}\right)$ feltételeztem, amely- 
ben a szokásos, vagyis a dominancia összeolvasztás müvelete által kapcsolódik az értelmező a szerkezethez, mivel az egyeztetés alakulását két tényező - a közelségi elv és a jelölt jegyérték - befolyásolja, s ennek köszönhetően egyes példákban az értelmező, míg más példákban az értelmezett szó irányítja a mátrix mondatbeli állítmánnyal való egyezetést. A bennfoglalás szemantikai osztályába tartozó értelmező esetében azt láthattuk, hogy a példák többségében intonációs szünetet kell tartani az értelmező után is, ez alól kivételek a fókuszpozícióban megjelenő szerkezetek. Az intonációs szünet hiányát mutató konstrukciókhoz olyan szerkezetet rendeltem, amelyben két tagmondat koordinációja és a redundáns elemek elliptálása történik. A szoros értelmező esetében amellett foglaltam állást, hogy a két DP szoros egységet alkot. Külön meg kellett vizsgálni a személyes névmási értelmezett szót tartalmazó példákat, amelyeket - az azonosítás és a tulajdonítás osztályába tartozó értelmezőkhöz hasonlóan - appozíciós parentetikus frázisként ( $\mathrm{Par}_{\mathrm{APP}} \mathrm{P}-$ ként) elemeztem. Ezekben a szerkezetekben az állítmánnyal való egyeztetést a (személyt tekintve) jelölt jegyérték irányítja, ha az appozíció preverbális pozícióban jelenik meg. A tárgyi szerepben megjelenő szerkezetek azonban újabb problémát vetnek fel a konstrukció elemzése során, ezért ezeket az appozíciókat további vizsgálatok alá kell vetni. A mi férfiak típusú konstrukciókat szintén appozíciónak tartom, a szerkezettagok között szoros viszonyt feltételezve - a szoros értelmezőhöz hasonlóan.

Amellett érveltem, hogy érdemes megkülönböztetni a határozói értelmezőt a többi értelmezőfajtától. A határozói értelmezők esetében megpróbáltam elkülöníteni a valódi értelmezős szerkezetektől azokat a példákat, amelyekben két határozó is megjelenik, de mégsem állnak egymással értelmezős viszonyban. 


\section{AZ ÉRTELMEZŐ FOGALMA ÉS ÁLTALÁNOS JELLEMZŐI}

Miután külön-külön megvizsgáltam a hátravetett jelzői értelmezőt, az azonosító értelmezőt és a határozói értelmezőt a magyar nyelvben, a kapott eredmények alapján megpróbálom az értelmező fogalmát pontosítani, illetve a szerkezet általános jellemzőit ismertetni. Ebben a fejezetben térek ki arra a kérdésre is, hogy milyen példák nem sorolhatóak az értelmező fogalma alá, figyelembe véve az egyes értelmezőfajták tulajdonságait. Végül pedig állást foglalok, hogy a kutatásom eredményei az ,árvaházi” vagy az integrációs megközelítést támasztják-e alá.

\subsection{Az értelmező fogalma}

Az értelmező fogalmának megadását nehezíti, hogy a szoros és a laza értelmező két különböző szerkezet (korlátozó tulajdonság, intonáció stb.), illetve a definiálásban további nehézséget jelent a hátravetett jelzői értelmező használata a magyar nyelvben, mivel részben a szoros, részben a laza értelmezővel mutat rokonságot, ugyanakkor el is tér mindkettőtől abban, hogy esetében nem kötelező a szerkezettagok szomszédossága. Nehéz egy olyan definíciót adni, amely ezeket az eltérő szerkezeteket összefoglalóan jellemzi és írja körül.

\subsubsection{Az értelmezős konstrukció definiálása a jellemzői alapján}

A magyar nyelvü hagyományos leíró nyelvtanok nem adnak egy pontos definíciót az értelmezőre, hanem a tulajdonságok felsorolásával jellemzik a szerkezetet. Ezen megállapítások többsége azonban módosításra szorul. Az alábbiakban ezeket az állításokat fogom ismertetni, majd pontosítani, illetve kiegészíteni.

\subsubsection{A sorrend}

A leíró nyelvtanok szerint az értelmező mindig az alaptagja, vagyis az értelmezett szó után áll. Ezzel a kijelentéssel két probléma van: Ha az értelmezett szót alaptagnak tekintjük, ezzel azt sugalljuk, hogy a szerkezet két tagja között alárendelő viszony van, kizárva a mellérendelést vagy más elemzési lehetőséget. A másik probléma az értelmezett és az értelmező sorrendjével kapcsolatos, mert nem várhatjuk el ezt a sorrendet anélkül, hogy alaposabban meg ne vizsgálnánk a nemzetközi szakirodalomban szoros értelmezőnek nevezett fajtát (1a, b). Az (1a) példa esetében az értelmezett szót követi az értelmező, de (1b) esetében már fordított a szórend: az eredetileg értelmezős szerkezet tagjai felcserélődtek. 


\section{a. Miltiadész a hadvezér sokkal ismertebb, mint Miltiadész a pápa. \\ b. A hadvezér Miltiadész sokkal ismertebb, mint a pápa Miltiadész.}

Maga Károly (1958) is megemlíti, hogy a magyar szakirodalomtól a nemzetközi abban is különbözik, hogy az utóbbi szerint a szorosabb értelmező megelőzheti az értelmezettet. Ugyanakkor a 3.2.1 pont alatt - a szoros értelmezőnek a magyar nyelvben való megléte mellett érvelve - amellett foglaltam állást, hogy az (1b)-ben látható szerkezetek valójában nem tartoznak a szoros értelmezők közé, mivel csak az egyik szerkezettag visel esetragot - szemben az értelmezős konstrukció összes többi típusával (kivételt csak a határozói értelmezők képeznek). Ebből következik, hogy a magyar szoros értelmezős szerkezetekre is igaz, hogy az értelmező mindig követi az értelmezett szót.

Továbbá meg kell említeni Károly (1958) által felhozott néhány olyan példát, amelyekben látszólag az értelmező áll elöl. A teljesség igénye nélkül néhányat megismétlek közülük (2). A (2)-es adatok származási helye Károly (1958: 42-43).
a. Akármennyit elköltenék én pénzt.
b. Sokat akarok fogni lepkét

Mivel a (2)-ben látható és azokhoz hasonló példákat szeretném kizárni az értelmezők köréből (ahogyan ezt a 4.2.1 alatt meg is teszem), ezek az adatok sem szolgálhatnak érvként amellett, hogy az értelmező megelőzheti az értelmezett szót a magyar nyelvben.

Tehát a fentieket összegezve továbbra is azt állítom, hogy a magyar értelmezős szerkezetben a szerkezettagok sorrendje kizárólag a következő lehet: az értelmezett szót követi az értelmező. A leíró nyelvtanokat ezen a ponton csupán a szóhasználatot tekintve szükséges módosítani: az értelmezett szót nem nevezhetjük alaptagnak.

\subsubsection{Az egyeztetés}

A leíró nyelvtanok hangsúlyozzák, hogy az értelmezett szó és az értelmezö között számbeli és esetbeli egyeztetés van. Ez a megállapítás megint csak abban az esetben helytálló, ha a szerkezet két tagja közti viszonyt alárendelőnek tekintjük, nem számolva eközben más elemzési lehetőségekkel. Ha az értelmezős konstrukciót mellérendelésnek (Szabó 1955, Antal 1964), vagy a redukciós elv - szintén mellérendelő szerkezeten való - alkalmazásának (Jakab 1977 , 1978) vagy pedig két tagmondat koordinációjának és az azokon végrehajtott ellipszisnek 
(Szőke 2014a) tartjuk, már nem beszélhetünk a két tag közti egyeztetésről (agreement), csakis a szuffixumok egyezéséröl (sharing).

Balogh (2003) az értelmező mondatrészi szerepét vizsgálva hasonló következtetésre jut: az értelmezős szerkezetben nem esetbeli egyeztetés történik, mivel a két szerkezettag azonos mondatrész, vagyis ugyanolyan nyelvtani viszonyt fejeznek ki.

A 2.2.1 pont alatt láthattuk, hogy a hátravetett jelzői értelmező esetében mindig megegyezik a két szerkezettag esete. Ugyanez elmondható az azonosító értelmezőről is, egyetlen szépirodalmi példát találtam, amelyben a birtokos személyjel megjelenésének köszönhetően elhagyható a tárgyrag, de ettől függetlenül a két szerkezettag esete továbbra is megegyezik (3).

Bár a példák többségében valóban megfigyelhető az értelmezős szerkezet tagjainak számbeli egyezése is - néhány adat esetében ez csak értelmi egyezés (4) -, de a bennfoglalás osztályába tartozó appozíciók kivételt képeznek ez alól, megengedve, hogy az értelmezett szó többes számú, míg az értelmező egyes számú legyen (5a).

a. A három rózsát, a fehéreket veszem meg.

b. Három fiú, az iskola legjobb tornászai indulhatnak a megyei versenyen.
a. A ragadozó madarak, például a sas, a zsákmányszerzés bajnokai.
b. *A ragadozó madár, például a sasok, a zsákmányszerzés bajnokai / bajnoka.

Az (5a) példában látható, hogy a bennfoglaló appozíció szerkezettagjai között még értelmi számbeli egyezés sem történik. Ugyanakkor érdemes megemlíteni, hogy a számbeli egyezés hiánya csak akkor lehetséges a bennfoglalás példáiban, ha az értelmezett szó a többes számú, és az értelmező az egyes számú. Fordított esetben már nem léphet fel a számbeli egyezés hiánya, mivel sem szintaktikailag, sem szemantikailag nem lehetséges, hogy egyes számú főnévi csoport foglaljon magába egy többes számú fönévi csoportot (5b).

Tehát az értelmezős szerkezetet jellemző állítás a következőképpen módosul: az értelmezett szó és az értelmező között megfigyelhető az esetbeli és a számbeli egyezés a magyar nyelvben, kivéve a bennfoglaló azonosító értelmezőket, amelyek esetében a számbeli egyezés - bizonyos feltételek teljesülése esetén - nem kötelező. 


\subsubsection{A hangsúly}

A leíró nyelvtanok a következő megállapítást teszik: az értelmező rendszerint szünettel különül el a jelzett szótól, a szerkezetnek két hangsúlya van. Bár Károly (1958: 18) szerint ,az összes értelmezős szerkezetre kötelező érvénnyel jellemző a laza szerkesztésmód, tehát a tagoknak szünettel való elkülönülése, külön hangszakaszban való elhelyezkedése”, néhány sorral lejjebb mégis megengedi a szünet hiányát, hozzátéve, hogy ilyenkor „nem tipikusan értelmezős szerkezettel van dolgunk" (u.o. 19.).

A ,rendszerint” szó használatát valószínűleg az alábbi példák indokolják (6), amelyek eltérő intonációt mutatnak az értelmezős szerkezetek többségétől. A (6c-f) példák kapcsán Károly (1958: 41) megjegyzi, hogy a szerkezetben a szünet nagyon minimális vagy semmi. A (6a, b) példák Károly (1968: 33, 36)-ból származnak.
a. mi férfiak
b. A húst mindet megette.
c. vért keveset onta
d. Tiszta rímje már inkább van egytagú.
e. lámpa is volt kettö, de asztalunk nem volt hozzá egy se
f. mindenkinek van gondolata temérdek

[Arany: Buda halála]

[Horváth: Verstan]

[Veres]

[Csillag 1952: 538]

Ugyanakkor a vizsgált megállapítás nem számol a korábban már említett szoros értelmezővel (1), amelynek csak egy hangsúlya van, vagyis a két tag egyetlen intonációs egységet alkot.

A hangsúlyra vonatkozó megállapítás úgy pontos, ha a hátravetett jelzői értelmezőt és a laza értelmezőt jellemezzük úgy, hogy a szerkezetnek két hangsúlya van, és az értelmező rendszerint szünettel különül el az értelmezett szótól. A szoros értelmező esetében a szerkezettagok egyetlen intonációs egységet alkotnak. A határozói értelmező esetében mindkét hangsúlyozási módra találhatunk példát. Továbbá meg kell jegyezni, hogy a laza értelmező után is tartható intonációs szünet, felerősítve ez által a szerkezet parentetikus jellegét.

\subsubsection{A predikatív viszony}

A leíró nyelvtanok kiemelik az értelmezős konstrukció azon tulajdonságát, mely szerint át-

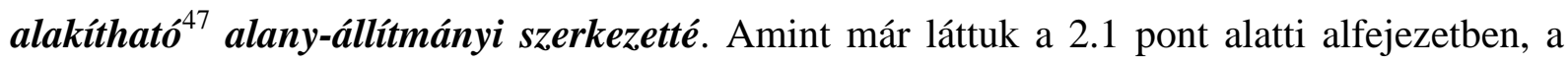

\footnotetext{
${ }^{47}$ Mint már említettem korábban, a hagyományos nyelvtanok az átalakítás fogalmát használják e jelenség körülírására, amely azonban nem feleltethető meg a generatív grammatikában használatos transzformáció fogalmának.
} 
hátravetett jelzői értelmezők esetében ezt az állítást módosítani kellett. Egyrészt példákkal illusztráltam, hogy a szerkezet tagjai csak akkor kerülhetnek egymással predikatív viszonyba, ha nem viselnek látható esetvégződést. Másrészt megmutattam azt is, hogy a nem metszetképző melléknévi, valamint a számnévi értelmezők esetében nem lehetséges a szerkezet tagjai között az alany-állítmányi viszony. Harmadrészt a felsőfokú melléknévi értelmező csak akkor töltheti be predikátum szerepét, ha egy határozott névelővel együtt jelenik meg (vagyis egy olyan DP részeként, amelyből a főnévi fej elliptálva van).

Az alany-állítmányi szerkezetté való átalakítás azonban nemcsak a hátravetett jelzői értelmező esetében jelenthet gondot, hanem az azonosító értelmezőnél is. Vegyük sorra a következő példákat (7). ${ }^{48}$

a. János, Magyarország leghíresebb festője $\rightarrow$ János Magyarország leghíresebb festöje volt.

b. Mari, a szomszédom $\rightarrow$ Mari a szomszédom volt.

c. Kis Kata, egy harmadrangú énekesnö a megyénkben $\rightarrow$ Kis Kata egy harmadrangú énekesnö volt a megyénkben.

d. Tóth Béla, az örnagy $\rightarrow$ *Tóth Béla az örnagy volt./ Tóth Béla volt az örnagy.

$(\rightarrow$ Tóth Béla örnagy volt.)

e. én, az író $\rightarrow$ *Én az író vagyok. / Én vagyok az író.

$(\rightarrow$ Én író vagyok.)

f. engem, a koronatanút $\rightarrow *$ Engem a koronatanút vagyok.

A (7a-c) példákban létrehozható predikatív viszony az értelmezett szó és az értelmező között anélkül, hogy az egyes szerkezettagokat meg kellene változtatni. A (7d-f) adatokban azonban kétféle alany-állítmányi viszony is előállítható: a határozott névelős értelmező predikátumként való megjelenése esetében azonosító állítmányt kapunk, míg az értelmező határozott névelőjének elhagyásával egy minősítő állítmánnyal állunk szemben. ${ }^{49} \mathrm{~A}(7 \mathrm{e})$ példában az is látható, hogy személyes névmási értelmezett szó esetén a szerkezettagok csak akkor kerülhetnek predikatív viszonyba egymással, ha egy kopula is megjelenik. A (7f) adat pedig azt példázza, hogy a hátravetett jelzői értelmezőhöz hasonlóan a predikatív viszony létrehozásának feltétele, hogy a szerkezettagok ne viseljenek látható esetvégződést.

\footnotetext{
${ }^{48}$ Az alany-állítmányi szerkezeteket tartalmazó mondatokat múlt időbe tettem, hogy egy kopula megjelenítésével érzékeltetni lehessen a jelentésárnyalatokat.

${ }^{49}$ A nemzetközi szakirodalomban az azonosító állítmányt tartalmazó mondat megfelelöje az equative copular clause, míg a minősítő állítmányt tartalmazó mondat megfelelöje a predicational copular clause.
} 
Ha az értelmezett szó és az értelmező is határozatlan főnévi csoport, akkor - a szerkezettagok határozottságának megváltoztatása nélkül - lehetetlen az értelmezős szerkezet átalakítása predikatív szerkezetté (8a).

a. Egy új játékot, egy szép babát szeretnék kapni. $\rightarrow$ *Egy új játék egy szép baba.

b. Egy új babát, a Gyöngyhercegnöt kaptam karácsonyra. $\rightarrow$ ? Egy új baba a Gyöngyhercegnö.

(8b)-ben csak az értelmezett szó határozatlan főnévi csoport, míg az értelmező nem, de az értelmezős konstrukció tagjaiból létrehozott predikatív szerkezetben nem az értelmezettről, hanem az értelmezőről állítunk valamit a szerkezet másik tagjának segítségével. Tehát abban az esetben, ha az értelmezett szó határozatlan főnévi csoport, nem lehetséges a szerkezettagok között a predikatív viszony létrehozása oly módon, hogy az értelmezett szóról predikálunk valamit az értelmező segítségével.

\subsubsection{Az értelmező definiálása a nyelvtani modulok felől}

Az előző pontban láthattuk, hogy nagyon nehéz egységes jellemzést adni az értelmezőről, mivel az egyes értelmezőfajták eltérő tulajdonságokkal bírnak. Emiatt megpróbálok egy olyan általános definíciót kidolgozni az értelmezőre, amely lefedi az összes típusát. Az értelmező fogalmának meghatározásakor érdemes különválasztani a prozódiai, szintaktikai, szemantikai és pragmatikai megközelítéseket.

Prozódia: Nincs olyan jellemző, amely az értelmező minden fajtáját lefedné.

Szintaxis: Az értelmezős szerkezet két tagból áll, amelyek azonos grammatikai funkciót látnak el.

Szemantika: Az értelmezős szerkezetben az értelmezett szót módosítja, kiegészíti, pontosítja vagy leszükíti az értelmező, és a két szerkezettag azonos referenssel bír (beleértve a magában foglalást is). A szerkezetnek saját propozíciója van, amely független a mátrix mondat propozicionális tartalmától.

Pragmatika: Az értelmezős üzenet egy konvencionális implikatúra (Potts 2005, Kim 2012), az értelmező segít a hallgatónak azonosítani az értelmezett referensét, arról új információval szolgálva.

A 14. táblázatban azokat a jellemzőket veszem sorra, amelyek a fenti meghatározáson túl jellemzik az egyes értelmezőfajtákat. 
14. táblázat: Az értelmező fogalma a nyelvtani modulok felöl ${ }^{50}$

\begin{tabular}{|c|c|c|c|c|c|}
\hline $\begin{array}{l}\text { Nyelvtani } \\
\text { modulok }\end{array}$ & $\begin{array}{ll}\text { Tulajdonságok } & \text { Értelmezőfajták } \\
\end{array}$ & $\begin{array}{l}\text { Hátravetett } \\
\text { jelzői ért. (9) }\end{array}$ & $\begin{array}{c}\text { Szoros értelme- } \\
\text { ző (10) }\end{array}$ & $\begin{array}{l}\text { Laza értelmezó } \\
\text { (11) }\end{array}$ & $\begin{array}{l}\text { Határozói ér- } \\
\text { telmező (12) }\end{array}$ \\
\hline Prozódia & Van intonációs szünet a szerkezettagok között. & + & - & + & $+/-$ \\
\hline \multirow[t]{3}{*}{ Szintaxis } & $\begin{array}{l}\text { A szerkezettagok kötelezően azonos szintaktikai po- } \\
\text { zícióban jelennek meg. }{ }^{51}\end{array}$ & - & + & + & + \\
\hline & Kötelező a szerkezettagok szomszédossága. & - & + & + & + \\
\hline & Megjelenhetnek appozíció-jelölők a szerkezetben. & + & - & + & + \\
\hline \multirow{3}{*}{$\begin{array}{l}\text { Szeman- } \\
\text { tika }\end{array}$} & Az értelmező korlátozó szerepü. & + & + & - & - \\
\hline & $\begin{array}{l}\text { A szerkezettagok együttesen határozzák meg a DP } \\
\text { referenciáját. }\end{array}$ & - & + & - & - \\
\hline & $\begin{array}{l}\text { Az értelmező kiegészítő információt ad az értelme- } \\
\text { zettről. }{ }^{52}\end{array}$ & + & - & $+1-$ & $+1-$ \\
\hline $\begin{array}{l}\text { Pragma- } \\
\text { tika }\end{array}$ & $\begin{array}{l}\text { Az értelmezett szónak egyedülállósági előfeltevése } \\
\text { van. }\end{array}$ & + & - & + & + \\
\hline
\end{tabular}

\footnotetext{
${ }^{50}$ A + jel jelöli egy adott tulajdonság meglétét, míg a - jel a szóban forgó jellemző hiányára utal.

${ }^{51} \mathrm{Ha}$ a hátravetett jelzői értelmező posztverbális pozícióban jelenik meg, akkor a szerkezettagok állhatnak eltérő szintaktikai pozícióban is (ilyenkor az értelmező - ellentétben az értelmezett szóval -fókusz szerepét tölti be (lásd zsilipeléses példák a 2.5.2.2 pont alatti alrészben).

${ }^{52}$ A laza és a határozói értelmező esetében ha a szerkezettagok a bennfoglalás viszonyában állnak egymással, akkor az értelmező szűkíti az értelmezett szó jelentését, és nem kiegészítő információt ad arról.
} 
(9) a. A sportolók, a vesztesek rosszkedvüen vonultak le a pályáról.

b. Három almát vettem, zöldeket, a sarki zöldségesnél.

(10) Kosztolányit az írót jobban kedvelem, mint Kosztolányit a költöt.

(11) a. Meglátogattam Marit, a barátnőmet.

b. A szomszédom, valamikor maga is nagy pókerjátékos, áthívott kártyázni.

(12) a. Felhívom kedden, vagyis január 6-án.

b. Kinn a szabadban tartjuk a gyermeknapot.

\subsection{Mi nem tartozik az értelmezők csoportjába?}

Ebben az alfejezetben azokat a példákat veszem sorra, amelyeket a hagyományos leíró nyelvtanok az értelmezők közé soroltak, vagy amelyek látszólag az értelmezős konstrukciók körébe tartoznak, de bizonyos okokból mégsem nevezhetjük őket valódi értelmezős szerkezetnek.

\subsubsection{A nem hátravetett jelzői értelmezők}

Elöször azokat a példákat ismertetem, amelyeket a korábbi nyelvtanok a hátravetett jelzői értelmezők között tárgyaltak.

Simonyi (1913) és Károly (1958) is felsorol olyan példákat, amelyekben szerintük a mutató névmás értelmezőként jelenik meg (13). A (13d) adat Simonyi (1913: 125) saját példája.

(13) a. Vadat és halat, azt látok én.

[Arany: A walesi bárdok]

b. Hazudni azt tudnak.

[Népszava, S. Zs. 124]

c. A lovat is azt ütik, aki a legjobban húz.

[Kovács: Közmondások 92]

d. bort annyit ittak, hogy egészen eláztak

A (13)-as példák egy kontrasztív topikot tartalmaznak, amelyről egyrészt az intonáció árulkodik, másrészt a mutató névmás megjelenése még nyomatékosabbá teszi a mondat élére kimozgatott összetevőt. A mutató névmás a (13a, b) adatokban azért sem lehet hátravetett jelzői értelmező, mert nem korlátozza, pontosítja vagy szúkíti az előtte megjelenő szerkezettag jelentését. Ugyanakkor a (13c)-ben és a (13d)-ben a mutató névmások a hozzájuk kapcsolódó vonatkozó tagmondatok miatt már korlátozzák az előttuik álló főnévi csoportok jelentését, ennek ellenére ezeket a példákat is kizárhatjuk az értelmezős szerkezetek köréböl. A kizárás magyarázata: a (13)-as példákban a preverbális pozícióban megjelenő értelmezős konstrukci- 
ókban a szerkezettagok nem ugyanabban a szintaktikai pozícióban állnak, ezért ezekben a példákban nem beszélhetünk értelmezős szerkezetekröl a hátravetett jelzői értelmezőt a szintaxis felöl megközelítő definíció alapján.

Továbbá Károly (1958: 42-43) bemutat néhány olyan adatot, amelyekben látszólag elöl áll az értelmező, majd ő maga is amellett érvel, hogy ezekben a példákban valójában nem értelmezős szerkezetek szerepelnek (14). A (14a, b) példák Károly (1958: 42-43)-ból származnak.
a. Akármennyit elköltenék én pénzt.
b. Sokat akarok fogni lepkét.
c. neked kevés van ilyen csillagod
d. várkapitányban ekkorát még nem láttam tolvajt

[Petőfi: A hazáról]

[Illyés: Dózsa]

Bár az alkalmi szófajváltás feltételezésével nem értek egyet (lévén, hogy a generatív grammatikában nem beszélhetünk alkalmi fönevesülésröl), de én is úgy gondolom, hogy a (14a-d)ben látható adatok nem értelmezős konstrukciók. Olyan főnévi csoportok jelennek meg ezekben az adatokban, amelyekből a főnévi fejet elliptáltuk, majd a beszélő - mondanivalójának egyértelműsítése érdekében - mégiscsak kiteszi a mondat végén az elliptált főnévi fejet. A mai magyar nyelvben azonban ezek a szerkezetek már archaikusnak tünnek.

A 2.4.2 pont alatt Cs. Nagy Lajos Nyelvtani elemzési gyakorlókönyvéböl (1991) már bemutattam néhány olyan példát, amelyeket a hagyományos nyelvtankönyvek a hátravetett jelzői értelmező alá sorolnak be, a teljesség igénye nélkül néhányat megismétlek közülük (15).
a. A beteg kompótot bármilyet és bármennyit megehet.
b. Kiflit akármennyit vehetsz.
c. Almát többet is ehetsz.

A fenti példákról már megállapítottam, hogy részben abban különböznek a többi hátravetett jelzői értelmezőtől, hogy a második tag nem korlátozza az elsőt, továbbá hogy a szerkezetben az első tag (és csak az) kontrasztív topikként jelenik meg, míg a második tag a kvantorpozíciót foglalja el. Mivel az értelmező - szintaxis felőli - fogalma szerint a preverbális helyzetben álló szerkezettagoknak azonos szintaktikai pozícióban kell megjelenniük, ezért a (15)-ös és az azokhoz hasonló példák is kizárhatók az értelmezők köréből. 


\subsubsection{A nem azonosító értelmezők}

A következőkben azokat a példákat veszem sorra, amelyek első pillantásra azonosító értelmezőnek tünnek, mégsem sorolhatjuk be őket az appozíciók közé.

Az azonosító értelmezők között tárgyalja (Károly 1958: 32) a kérdő névmást tartalmazó szerkezeteket (16).
a. Ki van itt jó munkás?
b. Mit láttál érdekeset?
c. Mi van eladó?
d. Szépet mit láttál?
e. Ügyes ember ki van ott?

A (16)-osban látható (és azokhoz hasonló) példákat azonban ki kell zárnunk az appozíciók közül. Egyrészt a 3. fejezetben az azonosító értelmező tulajdonságainak ismertetésekor amellett érveltem, hogy az értelmezett szónak és az értelmezőnek szomszédosnak kell lennie egymással, legfeljebb az appozíció-jelölök ékelödhetnek be közéjük, illetve komplex appozíció esetén az értelmezői kis tagmondat összetevői jelenhetnek meg a szerkezettagok között, de a mátrix mondat konstituensei nem. Az értelmező csak utógondolatként vagy erős intonációval kiejtett parentetikus közbevetésként távolodhat el az értelmezett szótól. Mindezek alapján kizárhatók a (16a-c) példák az appozíciók köréböl. Másrészt az értelmező tagjainak ugyanabban a szintaktikai pozícióban kell megjelenniük, és a (16)-os adatokban ez a feltétel sem teljesül. Bár a (16d, e) példákban a szerkezettagok szomszédosak egymással, de a mondatok intonációja arról árulkodik, hogy csak a kérdőszó van fókuszpozícióban, az első elem pedig (kontrasztív) topikként jelenik meg.

A szoros értelmezők esetében is találkozhatunk olyan adattal (17a), amely nagyon hasonlít az értelmezős szerkezetre (17b), de valójában mégsem az.
a. a költö Petöfi
b. Petöfi a költö

A 3.2.1 pont alatt amellett érveltem, hogy ha a szoros appozícióban (18a) felcseréljük a szerkezettagok sorrendjét, akkor a magyarban már nem értelmezővel állunk szemben, hanem egy főnévi módosítót tartalmazó DP-t kapunk (18b). 
A feltételezésemet azzal indokoltam meg, hogy a (18b)-ben található konstrukciók azért nem lehetnek szoros értelmezők, mert a szerkezeteknek csak az egyik tagja viseli az esetvégződést, márpedig a magyarban az értelmezők különféle fajtáiban (a határozói értelmező kivételével) mindkét szerkezettagon megjelent ugyanaz az esetrag. További érv lehet, hogy többes számú tulajdonnév mellett is megjelenhet főnévi módosító (19a), amelyeknek a sorrendje azonban már nem cserélhető fel (19b), vagyis nem hozható létre a tagok sorrendjének megváltoztatásával szoros értelmező.
a. A zeneszerzö Bachok ismertebbek a nyelvész Bachnál.
b. *Bachok a zeneszerzők ismertebbek Bachnál a nyelvésznél.

Továbbá (19a)-ban a szerkezettagok között nincs számbeli egyezés, amely azonban kötelező az értelmezős konstrukció szerkezettagjai között (kivéve a bennfoglaló értelmezőket, de azokban is csak bizonyos megszorításoknak eleget téve léphet fel a számbeli egyezés hiánya). Tehát mindezek alapján arra a következtetésre juthatunk, hogy a magyar nyelvben a szoros értelmező tagjainak felcserélésével már nem appozíciós szerkezettel állunk szemben.

Keresve a két szerkezet közötti kapcsolatot, felmerült annak lehetősége, hogy a költő Petőfi típusú konstrukciókat elliptikus szerkezetként elemezzük (20), hiszen ezáltal mégiscsak levezethetők lennének a szoros értelmezőből. Ez az elgondolás a vizsgált konstrukciót a hátravetett jelzői értelmezőkkel is rokonítaná, amelyekben a második tagból elliptáltuk a redundáns elemet.
a. a költö Petöfi
b. [a költő], [Petőfi a këltö]

Bár ezzel a megoldással valóban össze tudnánk kapcsolni a kétféle szerkezetet, hiszen a költő Petőfi típusú konstrukciók második tagja úgy jönne létre, hogy a szerkezetnek megfelelő szoros értelmezőből elliptáljuk a redundáns elemet, de két komoly probléma is adódik ezzel az elemzéssel. Egyrészt az intonációs változásokat nem tudnánk megmagyarázni, hiszen az ellipszis után nem tủnik el a szerkezettagok közötti intonációs szünet, valamint a szerkezetnek két hangsúlya van, míg a költő Petôfi típusú konstrukcióban nincs intonációs szünet, és az elemek 
nem kapnak külön-külön hangsúlyt. Továbbá arra sem kapunk magyarázatot, hogy az első elem esetragja miért tủnik el (21).

$$
\text { [a költőt], [Petőfit a költőt] } \rightarrow \text { a költő Petőfit }
$$

Mindezek alapján úgy vélem, hogy ellipszis feltételezésével nem hozható kapcsolatba egymással a kétféle szerkezet. A kérdés, hogy milyen kapcsolatban állnak a költö Petöfi és a Petőfi a költö típusú konstrukciók, további kutatást igényel.

\subsection{A hátravetett jelzői értelmező és az azonosító értelmező összehasonlí- tása}

A következőkben sorra veszem a hátravetett jelzői értelmező és az azonosító értelmező közötti különbségeket, amelyek megerősítik azt a feltevést, hogy két külön szerkezetről van szó, ezért a hagyományos elemzéssel szembehelyezkedve az értelmező e két típusát nem érdemes azonos módon kezelni. A 15. táblázat foglalja össze a kétféle értelmezős szerkezet főbb tulajdonságait.

\section{5. táblázat: A hátravetett és az azonositó értelmezö összehasonlítása}

\begin{tabular}{|l|l|}
\hline hátravetett jelzői értelmező & azonosító értelmező \\
\hline $\begin{array}{l}\text { A konstrukció átalakítható a tagok felcseré- } \\
\text { lésével jelzős szerkezetté. }\end{array}$ & $\begin{array}{l}\text { Rendszerint nem alakítható át jelzős szer- } \\
\text { kezetté a tagok felcserélésével. }\end{array}$ \\
\hline $\begin{array}{l}\text { A szerkezettagok között nem mindig hozha- } \\
\text { tó létre predikatív viszony. }\end{array}$ & $\begin{array}{l}\text { A szerkezettagok között általában létrehoz- } \\
\text { ható a predikatív viszony az azonosító és a } \\
\text { tulajdonító értelmező esetében, míg a benn- } \\
\text { foglalás példáiban sohasem. }\end{array}$ \\
\hline $\begin{array}{l}\text { A szerkezet tagjai elszakadhatnak egymás- } \\
\text { tól, nincs szomszédossági követelmény. }\end{array}$ & $\begin{array}{l}\text { A szerkezettagok nem szakadhatnak el } \\
\text { egymástól, legfeljebb appozíció-jelölők } \\
\text { kerülhetnek be közéjük. }\end{array}$ \\
\hline A szerkezet korlátozó. & $\begin{array}{l}\text { A laza értelmező nem korlátozó, míg a szo- } \\
\text { ros értelmező korlátozó. }\end{array}$ \\
\hline
\end{tabular}

\footnotetext{
${ }^{53}$ A rendszerint szó használatát az indokolja, hogy néhány azonosító értelmezőből létrehozható a hagyományos nyelvtanokban kijelölő jelzőnek nevezett szerkezet, ahogyan ezt az 5.1 pont alatt megmutattam (Mari, a fodrász $\rightarrow$ a fodrász Mari).
} 


\begin{tabular}{|l|l|}
\hline $\begin{array}{l}\text { Az állítmányt a hozzá közelebb álló szerke- } \\
\text { zettaggal egyeztetjük. }\end{array}$ & $\begin{array}{l}\text { Az egyeztetés alakulásában a közelségi } \\
\text { elven kívül más tényezők is szerepet játsza- } \\
\text { nak (lásd a 3.4 pont alatt). }\end{array}$ \\
\hline $\begin{array}{l}\text { Nem cserélhető fel a szerkezettagok sor- } \\
\text { rendje (mert akkor már azonosító értelme- } \\
\text { zőt kapunk). }\end{array}$ & $\begin{array}{l}\text { Felcserélhető a szerkezettagok sorrendje a } \\
\text { szoros és a bennfoglaló értelmező kivételé- } \\
\text { vel. }\end{array}$ \\
\hline $\begin{array}{l}\text { A szerkezettagok között számbeli és eset- } \\
\text { beli egyezés van. }\end{array}$ & $\begin{array}{l}\text { A szerkezettagok között esetbeli egyezés } \\
\text { van, a számbeli egyezés a bennfoglalás } \\
\text { példáiban nem kötelező. }\end{array}$ \\
\hline $\begin{array}{l}\text { A szerkezetnek két hangsúlya van. } \\
\text { A laza értelmezős szerkezetnek két hangsú- } \\
\text { lya van, míg a szoros értelmező egyetlen } \\
\text { intonációs egységet alkot. }\end{array}$ \\
\hline
\end{tabular}

\subsection{Integrációs kontra „árvaházi” megközelítés a szerkezet elemzéséhez}

Nemcsak az értelmezős konstrukció belső szerkezetét kell megvizsgálni, hanem felmerül az a kérdés is, hogy az értelmező hogyan kapcsolódik a vendéglátó tagmondathoz. Amint a dolgozatban már utaltam rá, a nemzetközi szakirodalomban az értelmező és a vendéglátó tagmondat kapcsolatát illetően két fő irányvonal verseng egymással: az „árvaházi” megközelítés szerint az értelmező szintaktikailag elszigetelődik az értelmezett szótól, míg az integrációs megközelítések egy strukturális viszonyt feltételeznek a szerkezettagok között. A teljesség igénye nélkül nézzünk meg néhány elképzelést.

Espinal (1991) amellett érvel, hogy a közbevetések és a vendéglátó tagmondat egy három-dimenziós modell különböző síkjain jelennek meg, 1́gy szintaktikailag függetlenek (22).

\section{János, a szomszédom egy rendes srác.}

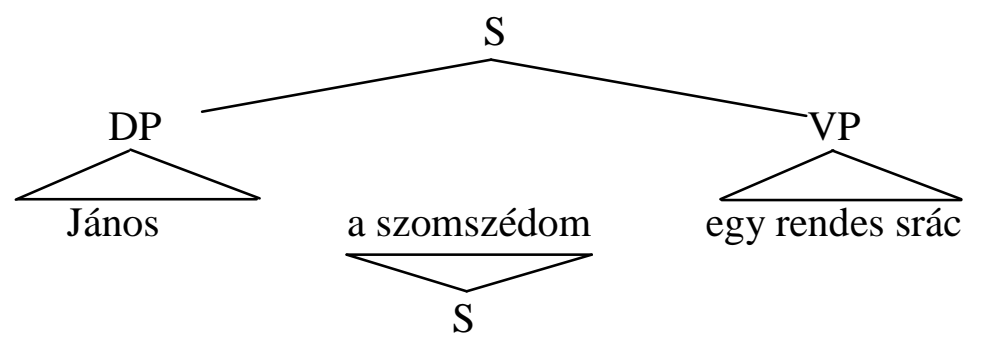


Haegeman (2009) szintén úgy gondolja, hogy a közbevetések a vendéglátó tagmondattól elkülönülve vannak deriválva, mintegy szintaktikai ,árvaként”, és csak a kontextualizálás során interpretáljuk a köztük lévő kapcsolatot.

De Vries $(2009,2012)$ szerint az értelmező ,pparentetikusan van koordinálva” az értelmezett szóhoz egy szintaktikai funkcionális Par-fej által.

Heringa (2012) amellett érvel, hogy az értelmezős közbevetések függetlenek a mátrix mondattól, ezért az értelmező a kiegészítő összeolvasztás müvelete által kapcsolódik az értelmezetthez, ami blokkolja a k-vezérlést, láthatatlanná téve az értelmezőt a többi elem számára.

Ott (2014) szerint az értelmezőt tartalmazó tagmondat szintaktikai integrációja nem szükségszerü, ráadásul egy antecedens tartalmú törlést eredményez. Ebből következően Ott a diskurzusbeli integráció mellett foglal állást: az értelmezőt tartalmazó $\mathrm{CP}_{2}$-t strukturálisan nem tartalmazhatja $\mathrm{CP}_{1}$, vagyis a lineáris közbeszúrás „szintaxis utáni”.

A következőkben vizsgáljuk meg, hogy milyen érvek szólhatnak a magyar példákat illetően az egyik vagy a másik megközelítés mellett. A hátravetett jelzői értelmezős szerkezet két tagmondatként és ellipszisként való elemzése esetében fel sem merülhet az a kérdés, hogy „árvaházi” vagy integrációs megközelítésről kell beszélnünk, mivel az értelmezős konstrukció nem egy mátrix tagmondatba ékelődik be. Az értelmezett szót magában foglaló $\mathrm{CP}_{1}$-t és $\mathrm{az}$ értelmezőt magában foglaló $\mathrm{CP}_{2}$-t koordinálva, majd a redundáns elemeket elliptálva kapjuk meg az értelmezős szerkezetet tartalmazó mondatot.

Az azonosító appozíció esetében már jóval összetettebb ez a kérdés. A mátrix mondatbeli állítmánynak az azonosító értelmezős szerkezettel való egyeztetését megvizsgálva láthattuk a 3.4 pont alatti alfejezetben, hogy bizonyos esetekben az értelmezett szó, míg más esetekben az értelmező irányítja az egyeztetést. Ebből adódóan amellett foglalok állást, hogy mindkét megközelítés szerepet játszik az azonosító értelmezők elemzése során. Kétféle szerkezetet kell megkülönböztetnünk: vannak olyan szerkezetek, amelyekben az értelmező után is tartunk szünetet, felerösítve ezáltal az appozíciós konstrukció közbevetéses jellegét, és vannak olyan konstrukciók, amelyekben nem tartunk intonációs szünetet az értelmező után. A kétféle appozícióhoz kétféle szerkezetet rendeltem az elemzés során. Az értelmező utáni szünet megjelenésekor a mátrix mondat állítmányát az értelmezett szóval kell egyeztetni, és az elemzés során alkalmazott szerkezet - a kiegészítő összeolvasztás mủvelete által - az ,árvaházi” megközelítések közé sorolható be. Az értelmező utáni szünet hiánya esetén a preverbális pozícióban megjelenő appozíciós konstrukciókban egyértelműen az értelmező irányítja a mátrix tagmondatbeli állítmánnyal való egyeztetést, ha a közelségi elv és a jelölt jegyérték nem kerül konfliktusba egymással. E két tényező konfliktusa esetén már ingadozás tapasztalható, hogy 
melyik szerkezettag váltja ki az állítmánnyal való egyeztetést. Mivel két tényező van hatással az egyeztetésre, és mivel az értelmező is kaphat irányító szerepet, az ilyen jellegü példák szerkezete - annak ellenére, hogy egyes adatokban az értelmezett szóval egyeztetjük az állítmányt - az integrációs megközelítések közé illeszthető be.

\section{5 Összegzés}

Ebben a fejezetben - a disszertáció eredményei alapján - megpróbáltam az értelmező fogalmát pontosítani a magyar példákra vonatkoztatva. Elöször a magyar nyelvészeti hagyományban használatos jellemzőket módosítottam. Bár az értelmezős konstrukcióban valóban mindig követi az értelmezett szót az értelmező, de helytelen az értelmezett szót alaptagnak nevezni. A szerkezettagok között nem esetbeli és számbeli egyeztetés, hanem egyezés figyelhető meg, és a bennfoglaló appozíció esetében megengedett a számbeli egyezés hiánya, ha az értelmezett szó a többes számú. A hangsúlyra vonatkozó megállapítás is módosításra szorult, mivel a szoros appozíciók és egyes határozói értelmezők esetében a szerkezettagok egyetlen intonációs egységet alkotnak. Végül azt az állítást is cáfoltam, hogy az értelmezős szerkezettagok között létrehozható predikatív viszony, hiszen ez nem igaz a hátravetett jelzői, a specifikációs és a predikációs értelmezők egyes példáira, illetve az összes bennfoglaló, valamint határozói értelmező ellentmond ennek a megállapításnak. Ezt követően a nyelvtani modulok felől közelítve meg a kérdést, egy átfogó, általános definíciót adtam az értelmezőre, amelyet kiegészítettem az egyes értelmezőfajtákra vonatkoztatva. Egységes prozódiai jellemző nem adható az összes értelmezőre. Közös szintaktikai jellemző, hogy a szerkezettagok ugyanazt a grammatikai funkciót látják el. A szemantika felől megközelítve elmondható, hogy az értelmezős szerkezetben az értelmezett szót módosítja, kiegészíti, pontosítja vagy leszükíti az értelmező, és a két szerkezettag azonos referenssel bír (beleértve a magában foglalást is), továbbá a szerkezetnek saját propozíciója van, amely független a mátrix mondat propozicionális tartalmától. A pragmatikai megközelítés szerint az értelmezős üzenet egy konvencionális implikatúra, az értelmező segít a hallgatónak azonosítani az értelmezett referensét, arról új információval szolgálva.

A különféle értelmezők tulajdonságait figyelembe véve megvizsgáltam, hogy milyen példák nem sorolhatóak az értelmező fogalma alá. Néhány olyan adatot ki kellett zárnom az értelmezők köréből, amelyeket korábban értelmezős szerkezetnek tartottak a magyar nyelvészek. Továbbá egy újabb érvet mutattam be, hogy a szoros értelmező szerkezettagjainak fel- 
cserélésével - szemben a nemzetközi szakirodalomban bemutatott példákkal - miért nem egy újabb appozíciós szerkezetet kapunk, hanem egy főnévi módosítóval ellátott DP-t.

Összehasonlítottam a hátravetett jelzői és az azonosító értelmezőt, hogy alátámasszam a különbségek felsorolásával azt a hipotézist, hogy két eltérő konstrukcióval állunk szemben, amelyekhez nem kell mindenáron ugyanazt a szerkezeti elemzést rendelni.

Végül pedig állást foglaltam, hogy a kutatásom eredményei részben az ,árvaházi”, részben az integrációs megközelítést támasztják alá, attól függően, hogy melyik értelmezőfajta szerkezetéről beszélünk. 


\section{5 ÖSSZEGZÉS}

A disszertáció témája a magyar értelmezős szerkezetek szintaktikai szempontú elemzése, mégpedig a generatív szintaxis elméleti keretén belül dolgozva.

A disszertációmban a következő kérdéseket igyekeztem megválaszolni: Milyen fajtákat különböztethetünk meg a magyar értelmezős szerkezetek körében? Milyen tulajdonságokkal rendelkeznek az egyes appozíciófajták? Hogyan kapcsolódik az értelmezős szerkezet a mátrix mondathoz, illetve milyen szintaktikai eljárásokban hogyan vesz részt? Milyen szerkezeti elemzés rendelhető az egyes appozíciófajtákhoz? Mindezek alapján mi az értelmező fogalma?

Mivel az egyes fejezetek végén részletes összefoglalót adtam, itt csak a főbb eredményeket kívánom ismertetni. Először is - részben a magyar nyelvészeti hagyományra, részben a nemzetközi szakirodalomra építve - megkülönböztettem egymástól az egyes értelmezős szerkezeteket. A magyar értelmezős szerkezeten belül három fő típust különítettem el: a hátravetett jelzői, az azonosító és a határozói értelmezőt. Továbbá amellett érveltem, hogy a magyarban is léteznek szoros értelmezők. Az azonosító appozíción belül további három típust különböztettem meg: az azonosítás, a tulajdonítás és a bennfoglalás szemantikai osztályába tartozókat. A különféle értelmezős konstrukciókat egyenként megvizsgáltam, és az eltérő jegyek miatt amellett foglaltam állást, hogy az egyes típusok esetében külön-külön kell elkészíteni a szerkezeti elemzést.

A dolgozat újdonsága, hogy a hátravetett jelzői értelmezőt két tagmondat koordinációjaként és ellipszisként elemeztem. Amint láthattuk, a kutatásommal párhuzamosan a nemzetközi irodalomban is megjelent egy olyan elképzelés, mely szerint az azonosító értelmezőt ellipszisként kellene elemezni (Ott 2014). A magyar nyelvben azonban az azonosító értelmezők nem elemezhetők ellipszisként, ennek a felfogásnak ellentmond az a szintaktikai folyamat, ahogyan az appozíciós konstrukció beépül a mátrix mondatba. Ennek kapcsán alapos vizsgálat alá vetettem a mátrix mondatbeli predikátumnak az azonosító értelmezővel való egyeztetését, tesztelve az adatokat.

A korábbi tanulmányokkal szemben nagyobb figyelmet szenteltem a határozói értelmezőnek, kicsit pontosabban körülhatárolva ezt a típust. A célom az volt, hogy ne merüljön fel annak lehetősége, hogy minden egymással szomszédos, azonos szerepet betöltő határozót értelmezős szerkezetnek tekintsünk.

Végül a kapott eredmények alapján arra törekedtem, hogy pontosítsam az értelmező fogalmát, azt több szempont felől is megközelítve. Továbbá olyan példákat is sikerült kizárnom 
az értelmezős szerkezetek köréből, amelyeket eddig tévesen tartottak értelmezős konstrukciónak.

Amint a disszertációból is kitünik, az értelmezők problematikája egy olyan kutatási terület, amellyel érdemes a jövőben is foglalkozni. A disszertáció csak érintette az ellipszis témakörét, de már ennyiből is jól látható, hogy ezen a területen is fontos lenne további kutatásokat végezni. A további tervek között szerepel egy olyan teszt összeállítása, amelyben nagyobb hangsúlyt fektetek az értelmező utáni szünet meglétére vagy hiányára, és amely egy hangzó anyagot foglalna magában. A bennfoglalás osztályába tartozó appozíciókat is szeretném beemelni a tesztmondatok közé. Fontos eredményekhez vezethet az értelmezős konstrukción belül az információs szerkezet szerepének alaposabb vizsgálata. A személyes névmást tartalmazó appozíciók kérdésköre szintén további vizsgálatokat igényel. Új eredményekhez vezethet a közbevetések szisztematikus áttekintése is. Mindezeken túl érdemes lenne a nem nominális értelmezőket is megvizsgálni. 


\section{MELLÉKLETEK}

\section{I. teszt}

Az alábbi mondatok egy tudományos kutatás részét képezik. Kérem, döntse el minden egyes mondatról, hogy jól formált szerkezet-e (pipálja ki) vagy nem jól formált (jelölje *-gal)! Ha bizonytalan a mondat jólformáltságát illetően, ha a szerkezetet nem tartja teljesen jól formáltnak, de teljesen rossznak sem, akkor kérdőjellel (?) jelölje! Nincs jó és rossz válasz, az Ön megítélésére vagyok kíváncsi olyan mondatok esetében, amelyekről eltérő intuícióval rendelkezünk. A mondatok nagyon hasonlóak, de nincs köztük két egyforma. Köszönöm a segítségét!

1. Annát, egy bájos kislányt felkértek a fotózásra.

2. Összeveszett a két lányom, Anna és Éva.

3. A két lányom, Anna és Éva tegnap megérkeztek.

4. A két lányom, Anna és Éva veszett össze.

5. Felkértek Annát, egy bájos kislányt a fotózásra.

6. A két lányom, Anna és Éva összeveszett.

7. Anna és a gyerekek tegnap megérkezett.

8. Összevesztek a két lányom, Anna és Éva.

9. A két lányom, Anna és Éva megérkezett.

10. Anna és Éva, a két lányom összevesztek.

11. Annát, egy bájos kislányt kértek fel a fotózásra.

12. A két lányom, Anna és Éva vesztek össze.

13. A két barátnőd, a lányaim tegnap megérkeztek.

14. Anna és a gyerekek tegnap megérkezett.

15. Összeveszett Anna és Éva, a két lányom.

16. Egy bájos kislányt, Annát kérték fel a fotózásra.

17. A lányaim, a két barátnőd megérkeztek.

18. Mari és a gyerekek tegnap összevesztek.

19. Összevesztek Anna és Éva, a két lányom.

20. A lányaim, a két barátnőd tegnap megérkeztek.

21. Anna és Éva, a két lányom veszett össze.

22. A lányaim, a két barátnőd megérkezett.

23. Felkérték Annát, egy bájos kislányt a fotózásra. 
24. Összeveszett a lányaim, a két barátnőd.

25. A két lányom, Anna és Éva tegnap összeveszett.

26. Annát kérték fel a fotózásra.

27. Anna és Éva, a két lányom megérkezett.

28. Összevesztek a lányaim, a két barátnőd.

29. Annát, egy bájos kislányt felkérték a fotózásra.

30. A két lányom, Anna és Éva összevesztek.

31. Anna és Éva, a két lányom megérkeztek.

32. Összeveszett a két barátnőd, a lányaim.

33. Egy lányt kérték fel a fotózásra.

34. A két barátnőd, a lányaim vesztek össze.

35. Anna és Éva, a két lányom összeveszett.

36. Egy bájos kislányt, Annát felkérték a fotózásra.

37. A két lányom tegnap összevesztek.

38. A két lányom, Anna és Éva tegnap megérkezett.

39. Felkértek egy bájos kislányt, Annát a fotózásra.

40. A két barátnőd, a lányaim veszett össze.

41. Anna és Éva, a két lányom tegnap megérkezett.

42. Anna és Mari tegnap összeveszett.

43. A két barátnőd, a lányaim megérkeztek.

44. A két lányom, Anna és Éva tegnap összevesztek.

45. Annát, egy bájos kislányt kérték fel a fotózásra.

46. A lányaim, a két barátnőd tegnap megérkezett.

47. Anna és Éva, a két lányom vesztek össze.

48. A két barátnőd, a lányaim megérkezett.

49. Anna és Mari tegnap összevesztek.

50. Egy bájos kislányt, Annát felkértek a fotózásra.

51. Anna és Éva, a két lányom összeveszett.

52. Anna és Éva, a két lányom tegnap megérkeztek.

53. Összevesztek a két barátnőd, a lányaim.

54. Felkérték egy bájos kislányt, Annát a fotózásra.

55. A lányaim, a két barátnőd veszett össze.

56. A két barátnőd, a lányaim tegnap megérkezett.

57. A két lányom, Anna és Éva megérkeztek. 
58. A két lányom tegnap megérkezett.

59. A lányaim, a két barátnőd vesztek össze.

60. Egy bájos kislányt, Annát kértek fel a fotózásra.

\section{II. teszt}

Az alábbi mondatok egy tudományos kutatás részét képezik. Kérem, döntse el minden egyes mondatról, hogy jól formált szerkezet-e (jelölje $\checkmark$-val) vagy nem jól formált (jelölje *-gal)! Ha bizonytalan a mondat jólformáltságát illetően, ha a szerkezetet nem tartja teljesen jól formáltnak, de teljesen rossznak sem, akkor kérdőjellel (?) jelölje!

FONTOS kérés: csak a vesszőnél tartson szünetet, különben változhat a mondatok megítélése! Köszönöm a segítséget!

(1) Egy bájos kislányt, Annát kértek fel a fotózásra.

(2) A lányaim, a két barátnőd megérkezett.

(3) Annát, egy bájos kislányt kérték fel a fotózásra.

(4) Összevesztek Anna és Éva, a két lányom.

(5) Egy bájos kislányt, Annát felkérték a fotózásra.

(6) A lányaim, a két barátnőd vesztek össze.

(7) A két barátnőd, a lányaim tegnap megérkeztek.

(8) Anna és Éva, a két lányom vesztek össze.

(9) Egy bájos kislányt, Annát kérték fel a fotózásra.

(10) A lányaim, a két barátnőd tegnap megérkezett.

(11) Összeveszett a két barátnőd, a lányaim.

(12) Anna és Éva, a két lányom tegnap megérkeztek.

(13) Annát, egy bájos kislányt felkértek a fotózásra.

(14) A két barátnőd, a lányaim megérkeztek.

(15) Annát, egy bájos kislányt felkérték a fotózásra.

(16) Anna és Éva, a két lányom összevesztek.

(17) A lányaim, a két barátnőd tegnap megérkeztek.

(18) Egy bájos kislányt, Annát felkértek a fotózásra.

(19) A lányaim, a két barátnőd veszett össze.

(20) A lányaim, a két barátnőd megérkeztek.

(21) Annát, egy bájos kislányt kértek fel a fotózásra.

(22) Anna és Éva, a két lányom megérkeztek. 
16. táblázat: A grammatikai ítéletek megoszlása

\begin{tabular}{|c|c|c|c|c|c|c|c|c|c|c|c|c|c|c|c|c|c|}
\hline A kérdőív kitöltői & \multirow[t]{2}{*}{1.} & \multirow[t]{2}{*}{2.} & \multirow[t]{2}{*}{3.} & \multirow[t]{2}{*}{4.} & \multirow[t]{2}{*}{5.} & \multirow[t]{2}{*}{6.} & \multirow[t]{2}{*}{7.} & \multirow[t]{2}{*}{8.} & \multirow[t]{2}{*}{9.} & \multirow[t]{2}{*}{10.} & \multirow[t]{2}{*}{11.} & \multirow[t]{2}{*}{12.} & \multirow[t]{2}{*}{13.} & \multirow[t]{2}{*}{14.} & \multirow[t]{2}{*}{15.} & \multirow[t]{2}{*}{16.} & \multirow[t]{2}{*}{17.} \\
\hline Tesztmondatok & & & & & & & & & & & & & & & & & \\
\hline Egy bájos kislányt, Annát kértek fel a fotózásra. & $*$ & $?$ & $*$ & $\checkmark$ & $\checkmark$ & * & $*$ & $*$ & $*$ & $*$ & $*$ & $*$ & $?$ & $\checkmark$ & $*$ & $*$ & $*$ \\
\hline A lányaim, a két barátnőd megérkezett. & $\checkmark$ & $?$ & $\checkmark$ & $\checkmark$ & $*$ & $\checkmark$ & $\checkmark$ & $*$ & $*$ & $*$ & $*$ & $?$ & $*$ & $*$ & $?$ & $*$ & $?$ \\
\hline Annát, egy bájos kislányt kérték fel a fotózásra. & $*$ & $\checkmark$ & $\checkmark$ & $\checkmark$ & $\checkmark$ & $\checkmark$ & $*$ & $*$ & $*$ & $\checkmark$ & $\checkmark$ & $\checkmark$ & $\checkmark$ & $*$ & $\checkmark$ & $\checkmark$ & $?$ \\
\hline Összevesztek Anna és Éva, a két lányom. & $*$ & $\checkmark$ & $\checkmark$ & $*$ & $*$ & $\checkmark$ & $\checkmark$ & $*$ & $\checkmark$ & $\checkmark$ & $?$ & $*$ & $\checkmark$ & $*$ & $?$ & $\sqrt{ } ?$ & $\checkmark$ \\
\hline Egy bájos kislányt, Annát felkérték a fotózásra. & $*$ & $\checkmark$ & $\checkmark$ & $\checkmark$ & $\checkmark$ & $\checkmark$ & $\checkmark$ & $\checkmark$ & $\checkmark$ & $\checkmark$ & $\checkmark$ & $\checkmark$ & $\checkmark$ & $*$ & $\checkmark$ & $\checkmark$ & $\checkmark$ \\
\hline A lányaim, a két barátnőd vesztek össze. & $*$ & $?$ & $\checkmark$ & $\sqrt{ }$ & $\checkmark$ & $\checkmark$ & $\checkmark$ & $*$ & $*$ & $\checkmark$ & $*$ & $? ?$ & $\checkmark$ & $?$ & $?$ & $?$ & $*$ \\
\hline A két barátnőd, a lányaim tegnap megérkeztek. & $*$ & $?$ & $\checkmark$ & $\checkmark$ & $\checkmark$ & $\checkmark$ & $\checkmark$ & $?$ & $*$ & $\checkmark$ & $*$ & $\checkmark$ & $\checkmark$ & $*$ & $?$ & $*$ & $\checkmark$ \\
\hline Anna és Éva, a két lányom vesztek össze. & $*$ & $\checkmark$ & $?$ & $*$ & $\checkmark$ & $\sqrt{ }$ & $\checkmark$ & $?$ & $*$ & $\checkmark$ & $\checkmark$ & $?$ & $\checkmark$ & $\checkmark$ & $?$ & $?$ & $\checkmark$ \\
\hline Egy bájos kislányt, Annát kérték fel a fotózásra. & $\checkmark$ & $\checkmark$ & $\checkmark$ & $\checkmark$ & $\checkmark$ & $\checkmark$ & $\sqrt{ }$ & $\checkmark$ & $\checkmark$ & $\checkmark$ & $\checkmark$ & $\checkmark$ & $\sqrt{ }$ & $?$ & $\checkmark$ & $\checkmark$ & $\checkmark$ \\
\hline A lányaim, a két barátnőd tegnap megérkezett. & $\checkmark$ & $\checkmark$ & $?$ & $\checkmark$ & $*$ & $\checkmark$ & $*$ & $\checkmark$ & $\checkmark$ & $*$ & $*$ & $*$ & $*$ & $*$ & $\checkmark$ & $*$ & $\checkmark$ \\
\hline Összeveszett a két barátnőd, a lányaim. & $?$ & $\checkmark$ & $\checkmark$ & $*$ & $\checkmark$ & $\checkmark$ & $*$ & $\checkmark$ & $\checkmark$ & $?$ & $?$ & $?$ & $\checkmark$ & $\checkmark$ & $?$ & $?$ & $\checkmark$ \\
\hline Anna és Éva, a két lányom tegnap megérkeztek. & $*$ & $\checkmark$ & $*$ & $*$ & $\checkmark$ & $\checkmark$ & $\checkmark$ & $*$ & $*$ & $\checkmark$ & $?$ & $?$ & $\checkmark$ & $*$ & $?$ & $\checkmark$ & $*$ \\
\hline Annát, egy bájos kislányt felkértek a fotózásra. & $?$ & $?$ & $\checkmark$ & $\checkmark$ & $?$ & $\checkmark$ & $\checkmark$ & $?$ & $*$ & $*$ & $*$ & $\checkmark$ & $\checkmark$ & $*$ & $*$ & $?$ & $\checkmark$ \\
\hline A két barátnőd, a lányaim megérkeztek. & $\checkmark$ & $?$ & $\checkmark$ & $\checkmark$ & $\checkmark$ & $\checkmark$ & $?$ & $\checkmark$ & $*$ & $\checkmark$ & $*$ & $\checkmark$ & $\checkmark$ & $*$ & $\checkmark$ & $\checkmark$ & $\checkmark$ \\
\hline Annát, egy bájos kislányt felkérték a fotózásra. & $*$ & $\checkmark$ & $\checkmark$ & $\checkmark$ & $\checkmark$ & $\checkmark$ & $\checkmark$ & $?$ & $*$ & $\checkmark$ & $\checkmark$ & $\checkmark$ & $\checkmark$ & $*$ & $?$ & $?$ & $?$ \\
\hline Anna és Éva, a két lányom összevesztek. & $*$ & $\checkmark$ & $*$ & $\checkmark$ & $\checkmark$ & $\checkmark$ & $\checkmark$ & $*$ & $\checkmark$ & $\checkmark$ & $?$ & $? ?$ & $\checkmark$ & $*$ & $?$ & $\checkmark$ & $*$ \\
\hline A lányaim, a két barátnőd tegnap megérkeztek. & $*$ & $\checkmark$ & $?$ & $\checkmark$ & $\checkmark$ & $\checkmark$ & $\checkmark$ & $?$ & $\checkmark$ & $\checkmark$ & $?$ & $?$ & $\checkmark$ & $*$ & $?$ & $?$ & $*$ \\
\hline Egy bájos kislányt, Annát felkértek a fotózásra. & $*$ & $\checkmark$ & $*$ & $\checkmark$ & $*$ & $\checkmark$ & $?$ & $*$ & $*$ & $*$ & $*$ & $?$ & $?$ & $*$ & $*$ & $*$ & $*$ \\
\hline A lányaim, a két barátnőd veszett össze. & $\checkmark$ & $?$ & $?$ & $\checkmark$ & $?$ & $\checkmark$ & $*$ & $\checkmark$ & $\checkmark$ & $*$ & $*$ & $*$ & $*$ & $\checkmark$ & $\checkmark$ & $*$ & $\checkmark$ \\
\hline A lányaim, a két barátnőd megérkeztek. & $?$ & $?$ & $?$ & $\checkmark$ & $\checkmark$ & $\checkmark$ & $\checkmark$ & $?$ & $\checkmark$ & $*$ & $*$ & $?$ & $\checkmark$ & $*$ & $?$ & $?$ & $*$ \\
\hline Annát, egy bájos kislányt kértek fel a fotózásra. & $*$ & $\checkmark$ & $?$ & $\checkmark$ & $*$ & $*$ & $*$ & $\checkmark$ & $\checkmark$ & $*$ & $?$ & $?$ & $?$ & $?$ & $*$ & $?$ & $?$ \\
\hline Anna és Éva, a két lányom megérkeztek. & $*$ & $\checkmark$ & $*$ & $\sqrt{ }$ & $\sqrt{ }$ & $\checkmark$ & $\sqrt{ }$ & $*$ & $*$ & $\checkmark$ & $\checkmark$ & $?$ & $\checkmark$ & $*$ & $\checkmark$ & $\checkmark$ & $*$ \\
\hline
\end{tabular}




\section{A rövidítések feloldása}

Acc $=$ accusativus (tárgyeset)

Adj = adjectival phrase (melléknévi frázis)

AdvP $=$ adverbial phrase (határozói frázis)

Aux $=$ auxiliary (segédige)

Comp $=$ complementizer $($ mondatbevezetö $)$

Cop $=$ kopula

$\mathrm{CP}=$ complementizer phrase (mondat értékü frázis)

Dat $=$ dativus (részes eset)

Def $=$ definite (határozott)

Dim = diminutive (kicsinyítő képző)

DP = determiner phrase (determinánsi frázis)

Ela $=$ elativus

FP = functional phrase (funkcionális frázis)

Gen $=$ genitivus $($ birtokos eset $)$

Ill = illativus

In = inessivus

Indef = indefinite (határozatlan)

Instr $=$ instrumentalis

Nom $=$ nominativus (alanyeset $)$

$\mathrm{NP}=$ noun phrase (fönévi csoport)

ParP $=$ pharenthetical phrase (parentetikus frázis)

$\operatorname{Par}_{\mathrm{APP}} \mathrm{P}=$ appositive pharenthetical phrase (appozíciós parentetikus frázis)

$\mathrm{Pl}=$ plural (többes szám)

pro $=$ pronomen (csak rejtetten jelen levő névmás)

$\mathrm{RC}=$ relative clause (vonatkozó tagmondat)

$\mathrm{S}=$ sentence (mondat)

$\mathrm{SC}=$ small clause (kis tagmondat)

$\mathrm{Sg}=$ singular (egyes szám)

Sub $=$ sublativus

Sup $=$ superessivus

$\mathrm{t}=$ trace (nyom)

$\mathrm{TP}=$ tense phrase (temporális frázis)

$\mathrm{VP}=$ verb phrase (igei frázis) 


\section{A szépirodalmi adatok forrásai}

Ady Endre: Összegyüjtött novellái. Athenaeum é. n. (Ady)

Arany János: Buda halála.

Arany János összes költeményei

Babits Mihály: Halálfiai. Athenaeum é. n. (Babits)

Hét évszázad versei. 1951. (Hét évsz.)

Horváth János: Rendszeres magyar verstan. 1951. (Horváth: Verstan)

Illyés Gyula: Puszták népe. 1948. (Illyés)

Jankovich Ferenc: Bün és bocsánat. 1956. (Jankovich)

Kaffka Margit: Válogatott müvei. 1956. (Kaffka)

Mikszáth Kálmán: A Noszty fiú esete Tóth Marival I-II. (Mikszáth: Noszty)

Móricz Zsigmond: Rokonok. 1932. (Móricz)

Szabó Pál: Lakodalom - Keresztelő - Bölcső. 1948. (Szabó)

Szabó Pál: Most és mindörökké I-II. 1956. (Szabó: Most)

Veres Péter: Pályamunkások. 1951. (Veres) 


\section{HIVATKOZÁSOK}

A. Jászó Anna (szerk.) 1991. A magyar nyelv könyve. Trezor Kiadó, Budapest.

Acuña-Fariña, Juan Carlos 1996a. The puzzle of apposition. On so-called appositive structures in English. Santiago de Compostela: Universidade, Servicio de Publicacións e Intercambio Científico.

Acuña-Fariña, Juan Carlos 1996b. On the structure of we boys, us girls and the like. Some Sundry Wits Gathered Together, 7-15.

Acuña-Fariña, Juan Carlos 1999. On apposition, English Language and Linguistics 3 (1): 5981.

Alberti Gábor \& Medve Anna 2002. Generatív grammatikai gyakorlókönyv II. Ágrajzok. Janus/Gondolat, Budapest.

Antal László 1964. A magyar jelző három különböző nyelvtani koncepció fényében, Magyar Nyelv 60: 61-68.

Antal László 1977. Egy új magyar nyelvtan felé. Magvető Könyvkiadó, Budapest.

Balázs János 1951. Mind, Magyar nyelv 51:1 40-50.

Balogh Judit 1999. A jelző és az értelmező, Magyar Nyelvőr 2: 191-207.

Balogh Judit 2003. Az értelmezős szerkezetek helye a szintagmák között, Magyar Nyelvőr 4: 456-471.

Balogh Judit 2004. Az értelmezős szerkezetek helye a szintagmák között II., Magyar Nyelvőr 1: $68-83$.

Baltin, Mark 2014. Structural approaches to ellipsis, Lingua 151: 1-8.

Bánréti Zoltán 2007. A mellérendelés és az ellipszis nyelvtana a magyarban. Tinta Könyvkiadó, Budapest.

Bartos Huba 2000a. Az inflexiós jelenségek szintaktikai háttere, in: Kiefer Ferenc (szerk.): Strukturális magyar nyelvtan III. Morfológia, Akadémiai Kiadó, Budapest, 653-762.

Bartos, Huba 2000b. Coordinate ellipsis as a phonological non-insertion, in: Bartos, Huba (ed): Papers on the Mental Lexicon, Research Institue for linguistics. Budapest, 41-67.

Bartos Huba 2000c. Az alanyi és a tárgyas ragozásról, in: Büky Ferenc \& Maleczki Márta (szerk.): A mai magyar nyelv leírásának újabb módszerei. IV. Szeged, 153-170.

Benkő Loránd (szerk.) 1967. A magyar nyelv története. Nemzeti Tankönyvkiadó, Budapest.

Bergenholtz, Henning 1985. Kasuskongruenz der Apposition, Beiträge zur Geschichte der deutschen Sprache und Literatur 107: 21-44. 
Bosque, Ignacio \& Carme Picallo 1996. Postnominal adjectives in Spanish DPs, Journal of Linguistics 32: 349-385.

Brassai Sámuel 1863. A magyar mondat III. Akadémiai Értesítő 3. 173-409.

Burton-Roberts, Noel 1975. Nominal apposition, Foundations of language 13: 391-419.

Burton-Roberts, Noel 1994. Apposition, in: R. E. Asher \& J. M. Y. Simpson (eds.): The Encyclopedia of Language and Linguistics. Oxford: Pergamon Press, 184-187.

Cardoso, Adriana \& Mark de Vries 2010. Internal an External Heads in Appositive Constructions, Manuscript, Lisbon \& Groningen: University of Lisbon \& University of Groningen.

http://www.let.rug.nl/dvries/pdf/2010-appositiveconstructions-webversion.pdf

Corazza, Eros 2005. On epithets qua attributive anaphors, Journal of Linguistics 41: 1-32.

Corbett, Greville G. 2000. Number. Cambridge University Press, Cambridge.

Craenenbroeck, Jeroen van \& Anikó Lipták 2006. The crosslinguistic syntax of sluicing: evidence from Hungarian relatives, Syntax 9:3, 248-274.

Crystal, David 1997. English is a Global Language. Cambridge University Press, Cambridge.

Curme, George Oliver 1947. English Grammar. New York: Barnes \& Noble.

Cs. Nagy Lajos 1991. Nyelvtani elemzési gyakorlókönyv. Trezor Kiadó, Budapest.

Del Gobbo, Francesca 2003. Appositives at the Interface. PhD Dissertation, Irvine: University of California.

Delorme, Ed \& Ray C. Dougherty 1972. Appositive NP constructions: we, the men; we men; I, a man; etc., Foundations of Language 8 (1): 1-29.

Dér Csilla 1999. A grammatikalizáció mint nyelvtörténeti folyamat. Néhány grammatikai morfémánk kialakulása. Szakdolgozat, ELTE, Budapest.

Dér Csilla 2001. Értelmezek, azaz azonosítok? Az értelmezős szerkezeten belüli grammatikai viszonyról, Magyar Nyelv 97:1, 77-82.

Dikken, Marcel den 2006. Relators and Linkers, Cambridge: The MIT Press.

Doron, Edit 1994. The discourse function of appositives, in: R. Buchalla \& A. Mitwoch (eds.): Proceedings of the ninth annual conference of the Israel Association for Theoretical Linguistics and of the workshop on discourse. Jerusalem: Hebrew University, 53-65.

Dürscheid, Christa 2002. „Polemik satt und Wahlkampf pur” - Das postnominale Adjectiv im Deutschen, Zeitschrift für Sprachwissenschaft 21: 57-81.

É. Kiss, Katalin 2012. Patterns of agreement with coordinate noun phrases in Hungarian, Natural Language \& Linguistic Theory 30 (4): 1027-1060, Springer. 
Espinal, Maria Teresa 1991. The representation of disjunct constituents, Language 67: 726762.

Evans, Gareth 1980. Pronouns, Linguistic Inquiry 11 (2): 337-362.

Farkas, Donka F. 1990. Two Cases of Underspecification in Morphology, Linguistic Inquiry 21: 539-550.

Farkas, Donka F. \& Henriëtte E. de Swart 2010. The semantics and pragmatics of plurals, Semantics and Pragmatics 3: 1-54.

Gécseg, Zsuzsanna 2012. Comment identifier le sujet des phrases copulatives du hongrois? Cahiers d'Études hongroises et finlandaises 18: 89-104.

Greenberg, Joseph. 1966. Language universals. Mouton, the Hague.

Gombocz Zoltán 1951. Syntaxis. Pázmány Péter Tudományegyetem Magyar Nyelvtudományi Intézete, Budapest.

Griffiths, James \& Mark de Vries 2012. The syntactic integration of appositives: evidence from fragments and ellipsis, Linguistic Inquiry 44 (2): 332-344.

Haegeman, Liliane 2009. Parenthetical Adverbs: The radical orphanage approach, in: B. Shaer, P. Cook, W. Frey \& C. Maienborn (eds.): Dislocated Elements in Discourse. New York: Routledge, 331-347.

Harley, Heidi \& Elizabeth Ritter 2002. Person and number in pronouns: a feature-geometric analysis, Language 78: 482-526.

Hannay, Mike \& Evelien Keizer 2005. A Discourse Treatment of English Non-Restrictive Nominal Appositions in Functional Discourse Grammar, in: J. L. Mackenzie \& M. de los Ángeles Gómez-González (eds.): Studies in Functional Discourse Grammar. Bern: Peter Lang, 159-194.

Heringa, Herman 2012. Appositional constructions. PhD thesis, University of Groningen. LOT Dissertation Series 294.

Hockett, Charles Francis 1955. Attribution and Apposition, American Speech 30: 99-102.

Huddleston, Rodney 1984. Introduction to the Grammar of English. Cambridge: Cambridge University Press.

Huddleston, Rodney \& Geoffrey K. Pullum 2002. The Cambridge Grammar of the English Language. Cambridge: Cambridge University Press.

Jakab István 1972. A jelzős szerkezetek redukciójának szószerkezeti vizsgálata, Magyar Nyelvőr 96: 38-50.

Jakab István 1977. Az értelmező és az értelmezett szószerkezeti viszonya, Magyar Nyelvőr 101: 9-19. 
Jakab István 1978. Igen, az értelmező mellérendelés, Magyar Nyelvőr 102: 293-298.

Johnson, Kyle 2014. Commentary on 'Gender mismatches under nominal ellipsis' by Jason Merchant, Lingua 151: 33-42.

Károly Sándor 1958. Az értelmező és az értelmezői mondat a magyarban. NytudÉrt. 16. Akadémiai Kiadó, Budapest.

Keizer, Evelien 2005. The discourse function of close appositions, Neophilologus 89: 447467.

Keszler Borbála (szerk.) 2000. Magyar grammatika. Nemzeti Tankönyvkiadó, Budapest.

Keszler Borbála \& Lengyel Klára 2002. Kis magyar grammatika. Nemzeti Tankönyvkiadó, Budapest.

Kiefer Ferenc 1983. Az előfeltevések elmélete. Akadémiai Kiadó, Budapest.

Kiefer Ferenc 1998. Alaktan, in: É. Kiss Katalin - Kiefer Ferenc - Siptár Péter: Új magyar nyelvtan. Osiris Kiadó, Budapest, 187-290.

Kim, Jong-Bok 2012. Form and Function Mismatch in the English Appositional Construction, Language Research 48 (3): 1-23.

Koktová, Eva 1986. Apposition as a Pragmatic Phenomenon in a Functional Description. Duisburg: Linguistic Agency University of Duisburg.

Kolliakou, Dimitra 2004. Monadic definites and polydefinites: their form, meanning and use, Journal of Linguistics 40: 263-333.

Larson, Bradley 2012. A Dilemma with Accounts of Right Node Raising, Linguistic Inquiry 43 (1): 143-150.

Lasersohn, Peter 1986. The semantics of appositive and pseudo-appositive NP's, Proceedings of the Eastern States Conference on Linguistics 3: 311-322.

Lehmann, Christian 1984. Der Relativsatz. Tübingen: Gunter Narr Verlag.

Lekakou, Marika \& Kriszta Szendröi 2007. Eliding the noun in close apposition, or Greek polydefinites revisited, in: Richard Breheny \& Nikolaos Velegrakis (eds.): UCL Working Papers in Linguistics. University of London, University College London, pp. 27, 129-154. Internet: http://www.phon.ucl.ac.uk/publications/WPL/uclwpl19.html.

Merchant, Jason 2001. The syntax of silence: Sluicing, islands, and the theory of ellipsis. Oxford University Press: Oxford.

Merchant, Jason 2004. Fragments and ellipsis, Linguistics and Philosophy 27: 661-738.

Merchant, Jason 2010. Three kinds of ellipsis, in: Francois Recanati, Isidora Stojanovic, Neftali Villanueva (eds.): Context-Dependence, Perspective, and Relativity. Walter de Gruyter: Berlin, 141-192. 
Merchant, Jason 2013. Diagnosing ellipsis, in: Lisa Lai-Shen Cheng and Nobert Corver (eds.): Diagnosing syntax. Oxford University Press: Oxford, 537-542.

Merchant, Jason 2014. Gender mismatches under nominal ellipszis, Lingua 151: 9-32.

Molitor, Friedhelm 1979. Zur Apposition im heutigen Deutsch. Eine Vorstudie. PhD Dissertation, University of Cologne. Siegen: Buchbinderei M. Höpner.

Munn, Alan 1998. ATB Movement wihtout Identity, in: Jennifer Austin \& Aaron Lawson (eds.): Proceedings of ESCOL 97. Ithaca: Cornell Linguistics Club Publications, 1-11.

O’Connor, Kathleen M. 2008. Aspects de la syntaxe et de l'interprétation de l'apposition à antécédent nominal. PhD Dissertation, Université Charles de Gaulle, Lille 3.

Ott, Dennis 2014. Ellipsis in appositives and the syntax of parenthesis, handout, GLOW 37 (Brussels).

Peterson, Peter 1999. On the boundaries of syntax, in: P. Collins \& D. Lee (eds.): The Clause in English. In Honour of Rodney Huddleston. Amsterdam: John Benjamins, 229-250.

Pollman, Thijs 1975. Een regel die subject en copula deleert?, Spektator 5: 282-292.

Postal, Paul 1964. On So-Called Pronouns in English, in: Dinneen (ed.): reprinted in Reibel and Schane, 201-224.

Potts, Christopher 2005. The logic of conventional implicatures. New York: Oxford University Press.

Pysz, Agnieszka 2009. The Syntax of Prenominal and Postnominal Adjectives in Old English. Cambridge Scholars Publishing.

Quirk, Randolph, Sidney Greenbaum, Geoffrey Leech \& Jan Svartvik 1985. A comprehensive grammar of the English language. London: Longman.

Rácz Endre (szerk.) 1968. A mai magyar nyelv. Tankönyvkiadó, Budapest.

Rácz Endre 1991. Az egyeztetés a magyar nyelvben. Akadémiai Kiadó, Budapest.

Roberts, Craige 1996. Anaphora in Intensional Contexts, in: S. Lapin (ed.): The Handbook of Contemporary Semantic Theory. Oxford: Blackwell, 215-246.

Ross, John Robert 1967. Constraints on Variables in Syntax. PhD dissertation, Massachusetts Institute of Technology.

Safir, Ken 1986. Relative Clauses in a Theory of Binding and Levels, Linguistic Inquiry 17: 663-689.

Sells, Peter 1985. Restrictive and non-restrictive modification, CSLI Report 85-28, Stanford: CSLI Publications.

Simonyi Zsigmond 1895. Tüzetes magyar nyelvtan történeti alapon. BALASSA JózSEF közremüködésével írta SiMONYi ZsigmOND. 1. Magyar hangtan és alaktan. MTA, Budapest. 
Simonyi Zsigmond 1913. A jelzők mondattana. Nyelvtörténeti tanulmány, Magyar Tudományos Akadémia, Budapest.

Smith, C. S. 1964. Determiners and Relative Clauses in a Generative Grammar of English, Language 40: 37-52.

Sode, Rumiko 2004. Nominal apposition in Japanese, Southwest Journal of Linguistics 23 (2): 187-214.

Sopher, H. 1971. Apposition, English Studies 52: 401-412.

Stavrou, Melita 1995. Epexegesis vs. apposition. Scientific Yearbook of the Classics Department. Aristotle University of Thessaloniki.

Sturm, Arie N. 1986: Primaire syntactische structuren in het Nederlands. PhD Dissertation, University of Nijmegen, Leiden: Nijhoff.

Szabó Dénes 1955. A mai magyar nyelv. Egyetemi jegyzet, kézirat, Budapest.

Szőke Bernadett 2011. A predikatív viszony a birtokos DP-ben, a befejezett melléknévi és a határozói igeneves szerkezetekben, in: Gécseg Zsuzsa (szerk.) LingDok 10. Nyelvészdoktoranduszok dolgozatai, Szeged, JATEPress Kiadó, 205-224.

Szőke Bernadett 2014a. A magyar minősítő értelmező mint ellipszis, in: Gécseg Zsuzsa (szerk.) LingDok 13. Nyelvészdoktoranduszok dolgozatai, Szegedi Tudományegyetem Nyelvtudományi Doktori Iskola, Szeged, 165-184.

http://nydi.bibl.u-szeged.hu/SZTE_NYDI/LingDok_konfkotetek_files/lingdok13.pdf

Szőke Bernadett 2014b. Újabb kutatások az értelmezőről, Magyar Nyelvőr 138 (3): 328-344.

Szőke, Bernadett 2015. The identifying apposition in Hungarian, Argumentum 11, Debreceni Egyetemi Kiadó, 1-28.

http://epa.oszk.hu/00700/00791/00012/pdf/EPA00791_argumentum_2015_11_001028.pdf

Szőke Bernadett (megjelenés alatt). Az azonosító értelmező vizsgálata a magyarban, in:

Gécseg Zsuzsa (szerk.) LingDok 15. Nyelvészdoktoranduszok dolgozatai, Szegedi Tudományegyetem Nyelvtudományi Doktori Iskola, Szeged.

Tompa József (szerk.) 1962. A mai magyar nyelv rendszere II. Akadémiai Kiadó, Budapest.

Tompa József 1964. „Egyik legnagyobb tévedése?”, Magyar Nyelv 60: 428-432.

Verseghy Ferenc 1816-17. Analytica institutionum linguae hungaricae. Pars I. Etymologia...

Pars II., Syntaxis linguae hungaricae. Pars III. Usus aestheticus. Három kötet (névtelenül), Buda.

Vries, Mark de 2006. The syntax of appositive relativization. On specifying coordination, false free relatives, and promotion, Linguistic Inquiry 37 (2): 229-270. 
Vries, Mark de 2009. Specifying Coordination: An Investigation into the Syntax of Dislocation Extraposition and Parenthesis, in: C. D. Dreyer (ed.): Language and Linguistics: Emerging Trends. New York: Nova, 37-98.

Vries, Mark de 2012. Unconventional Mergers, in: M. Uribe-Extebarria \& V. Valmala (eds.): Ways of Structure Building. Oxford: Oxford University Press, 143-166.

Wilder, Chris 1997. Some properties of Ellipsis in Coordination, in: Alexiadou, A. \& T. A. Hall (eds.): Studies on Universial Grammar and Typological Variation. Linguistik Aktuell/Linguistics Today, 59-107. 